UNIVERSIDADE DE SÃO PAULO

INSTITUTO DE ARQUITETURA E URBANISMO

LETÍCIA FRANÇA MATTARAIA

\title{
Arquitetura e Sustentabilidade: \\ Considerações sobre o Desmonte das Edificações
}





\section{Arquitetura e Sustentabilidade: \\ Considerações sobre o Desmonte das Edificações}

Dissertação apresentada ao Instituto de Arquitetura e Urbanismo da Universidade de São Paulo, como parte dos requisitos para obtenção do título de Mestre em Arquitetura e Urbanismo.

Área de concentração Arquitetura, Urbanismo e Tecnologia

Orientador

Prof. Assoc. Márcio Minto Fabrício 



\section{FOLHA DE JULGAMENTO}

Candidata: Arquiteto e Urbanista Letícia França Mattaraia

Título da dissertação: "Arquitetura e sustentabilidade: considerações sobre o desmonte das edificações"

Data da defesa: 01/11/2013

\section{Comissão Julgadora:}

\section{Resultado:}

Prof. Associado Márcio Minto Fabricio (orientador) (Instituto de Arquitetura e Urbanismo - IAU/USP)

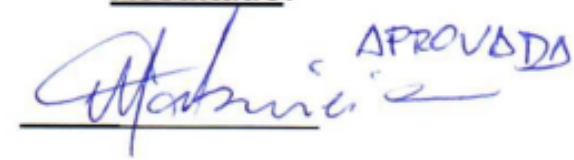

Profa. Associada Akemi Ino

(Instituto de Arquitetura e Urbanismo - IAU/USP)

Profa. Dra. Mônica Santos Salgado

(Universidade Federal do Rio de Janeiro - UFRJ )

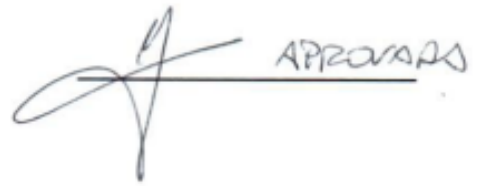

Presidente e Coordenador do Programa de Pós-Graduação em Arquitetura

Urbanismo: Professor Titular Renato Luiz Sobral Anelli 

AUTORIZO A REPRODUÇÃO TOTAL OU PARCIAL DESTE TRABALHO, POR QUALQUER MEIO CONVENCIONAL OU ELETRÔNICO, PARA FINS DE ESTUDO E PESQUISA, DESDE QUE CITADA A FONTE.

Mattaraia, Letícia

M435a Arquitetura e Sustentabilidade: Considerações sobre o Desmonte das Edificações / Leticia Mattaraia;

orientador Márcio Fabrício. São Carlos, 2013.

Dissertação (Mestrado) - Programa de Pós-Graduação em Arquitetura e Urbanismo e Área de Concentração em Arquitetura, Urbanismo e Tecnologia - Instituto de Arquitetura e Urbanismo da Universidade de São Paulo, 2013.

1. projeto para o desmonte. 2. arquitetura sustentánel. 3. sustentabilidade. 4. design for disassembly. I. Título 

Dedico este trabalho a toda minha família, amigos, professores e colegas. 



\section{AGRADECIMENTO}

Primeiramente agradeço a Deus, pela minha vida e saúde.

Agradeço a minha família, principalmente aos meus pais Lincoln e Gislaine Mattaraia que sempre apoiaram as minhas decisões.

Ao meu orientador Prof. Dr. Márcio Minto Fabrício, pelo incentivo, motivação e grande contribuição no desenvolvimento do trabalho, ao longo desses anos.

Aos colegas do grupo de pesquisa Arquitec que se tornaram grandes amigos e companheiros ao longo do desenvolvimento deste trabalho. Além de contribuíram com informações e incentivos.

Aos meus amigos que me acompanharam neste processo e sempre me incentivaram.

Aos colegas da pós-graduação que contribuíram com ótimas ideias, sugestões e importantes discussões.

Aos professores das diversas disciplinas cursadas que contribuíram trocando importantes informações e dividiram seu conhecimento.

Aos professores que participaram da minha banca de qualificação e de defesa, Profa. Dra. Akemi Ino e Prof. Dra. Monica Santos Salgado, que fizeram importantes ressalvas sobre o trabalho.

Às pessoas dispostas a darem entrevistas e principalmente ao Eng. Frederico del Villar, ao Arq. José Mário Nogueira, à Arq. Sônia Lúcia Medeiros da Silva Costardi e à Prof. Dra. Cláudia Terezinha de Andrade Oliveira, que fornecerem informações referentes aos estudos empíricos, pois enriqueceram o trabalho.

Ao IAU que fornece condições e toda a estrutura para o desenvolvimento das pesquisas.

Finalmente, ao CNPQ que contribuiu com o apoio financeiro. 

"A menos que modifiquemos a nossa maneira de pensar, não seremos capazes de resolver os problemas causados pela forma como nos acostumamos a ver o mundo."

Albert Einstein 



\section{SUMÁRIO}

AGRADECIMENTO XI

SUMÁRIO

LISTA DE TABELAS V

LISTA DE FIGURAS VII

GLOSSÁRIO DE TERMOS E ABREVIACÕES XI

RESUMO 15

ABSTRACT 17

1. INTRODUCCÃO 19

1.1 ObJetivos da Pesquisa $\quad 24$

$\begin{array}{lll}1.2 & \text { JUSTIFICATIVA } & 25\end{array}$

1.3 MÉTOdO DE PESQUISA 28

1.4 DELINEAMENTO DA PESQUISA 29

1.4.1 LEVANTAMENTO E REVISÃo BIBLIOGRÁFICA 29

1.4.2 PESQUISA DESCRITIVA - ESTUdO DE CAMPO 30

1.4.3 ESTRUTURA DA DisSERTAÇ̃̃O

$\underline{2}$ ARQUITETURA E SUSTENTABILIDADE $\quad 37$

2.1 ANÁlise do Ciclo de Vida (ACV) 40

2.2 ACV E NORMAS

2.3 RESíduOS, RECICLAGEM E REUTILIZAÇÃo

3 PROJETO PARA O DESMONTE

3.1 Projeto PARA " $X "$ - BASE do CONCEITO do Projeto PARA O DeSMonte

3.2 PROJETO PARA DESMONTE EM DIVERSOS RAMOS INDUSTRIAIS 66 
$\begin{array}{llr}4.1 & \text { REVISÃO BIBLIOGRÁFICA } & 83\end{array}$

4.2 ESTUdOS EMPÍRICOS

4.2.1 DEMOLIÇÃO CONVENCIONAL 88

4.2.2 DEMOLIÇÃO CONTROLADA 91

4.2.3 REUTILIZAÇÃO DE ESTRUTURA DE MADEIRA 92

4.2.4 REUTILIZAÇÃo DE ESTRUTURA METÁLICA 93

4.2.5 DESMONTAGEM EKo HOUSE 94

$\underline{5}$ PESQUISA DESCRITIVA - ESTUDOS EMPÍRICOS

5.1 DEMOLIÇÃo CONVENCIONAL 98

5.2 DEMOLIÇÃo CONTROLADA 102

5.3 CONSTRUÇÃO COM REUTILIZAÇÃO DE MATERIAIS 106

5.3.1 REUTILIZAÇÃO DE ESTRUTURA DE MADEIRA 106

5.3.2 REUTILIZAÇÃO DE ESTRUTURA METÁLICA 112

5.4 DESMONTAGEM (EKO HOUSE) 120

$\begin{array}{lll}5.5 & \text { ANÁLISE DOS DAdOS } & 128\end{array}$

$\underline{6}$ DIRETRIZES 133

6.1 Processo de DESENVOLVIMENTO DAS DIRETRIZES

6.1.1 EXEMPLO RELACIONADO À DEMOLIÇÃO CONVENCIONAL 135

6.1.1 EXEMPLO RELACIONADO À DEMOLIÇÃO PROGRAMADA 136

6.1.1 EXEMPLO RELACIONADO AO REAPROVEITAMENTO DE MATERIAIS 137

6.1.2 EXEMPLO RELACIONADO A EKO HOUSE 138

6.2 DIRETRIZES DISPOSTAS EM GRUPOS 139

6.2.1 QUANTO AOS SISTEMAS CONSTRUTIVOS 140

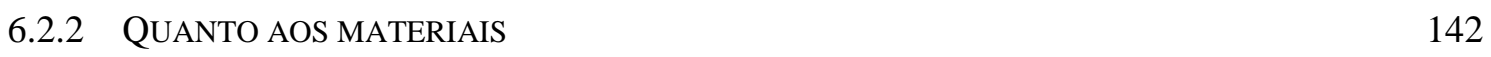

6.2.3 QUANTO AOS REVESTIMENTOS E ACABAMENTOS 145

6.2.4 QUANDO ÀS LIGAÇÕES E CONEXÕES 146

$\begin{array}{ll}\text { 6.2.5 DIRETRIZES GERAIS PARA PROJETO } & 148\end{array}$

$\underline{7}$ CONCLUSÕES 157 
A. Entrevista com ArQuiteto 01

B. Segunda entrevista COM O ARQuiteto 01

C. EnTREVISTA COM A ARQUITETA $02 \quad 187$

D. ENTREVISTA ENGENHEIRO DA EMPRESA A 187

E. QUESTIONÁRIO RESPONDIDO PELO DIRETOR DA EMPRESA B 189

F. ENTREVISTA PROFESSORA SOBRE EKO HOUSE

G. DADOS DO ACOMPANHAMENTO DA DEMOLIÇÃO 193

H. Proposta de Checklist 197

CHECKLIST REFERENTE A QUESTÕES GERAIS 197

$\begin{array}{ll}\text { CHECKLIST COM PONTUAÇÃO } & 201\end{array}$ 


\section{LISTA DE TABELAS}

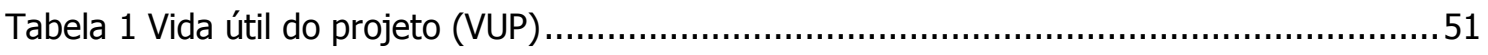

Tabela 2 Processos de construção civil e vida útil ..................................................... 52

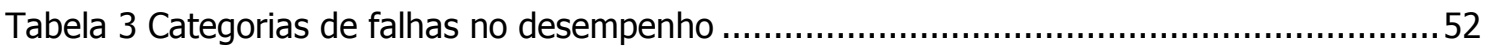

Tabela 4 Categoria de vida útil de projeto para partes do edifício .....................................5

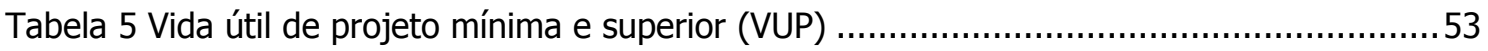

Tabela 6 Conceitos que contribuem para o Projeto para o Desmonte, no contexto industrial em

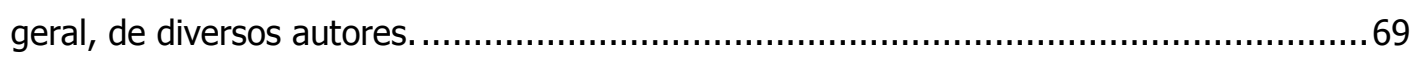

Tabela 7 Características de desmonte de diversos sistemas estruturais ................................79

Tabela 8 Conceitos que contribuem para o Projeto para o Desmonte de diversos autores ........80

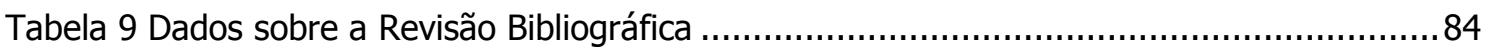

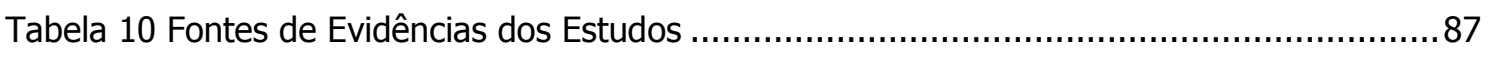

Tabela 11 Atividades Realizadas relacionadas ao Estudo de Caso da Demolição Convencional . 89

Tabela 12 Atividades Realizadas relacionadas ao Estudo Exploratório de Demolição Programada

Tabela 13 Atividades Realizadas relacionadas ao Estudo Exploratório de Reutilização de

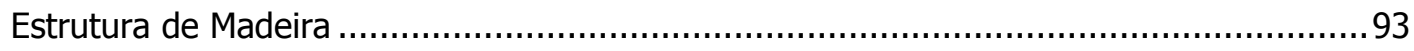

Tabela 14 Atividades Realizadas relacionadas ao Estudo Exploratório de Reutilização de

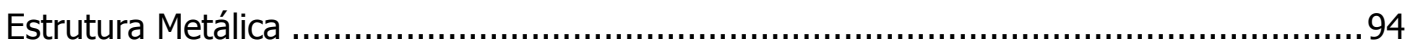

Tabela 15 Atividades Realizadas relacionadas ao Estudo de Caso da Eko House .....................95

Tabela 16 Materiais que puderam ser aproveitados para futura revenda e materiais que se transformaram em entulhos. .................................................................................. 99

Tabela 17 Checklist do Projeto para o Desmonte na construção Civil................................. 197

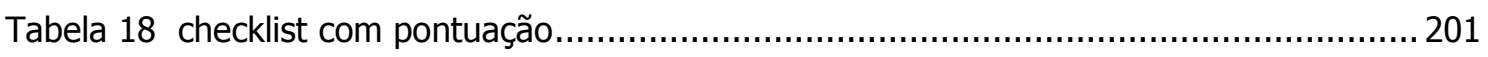




\section{LISTA DE FIGURAS}

Figura 1 Representação esquemática da ACV

Figura 2 Esquema de ciclo de vida em que o material pode ser reaproveitado através da reciclagem, remanufatura e reutilização.

Figura 3 Aplicação de ACV nos produtos de construção civil 48

Figura 4 Distinção entre uma descrição técnica de um sistema de produto e procedimentos de alocação para reciclagem 50

Figura 5 Diversos tipos de ligações 74

Figuras 6, 7 e 8 Imagens da demolição e separação de alguns materiais 100

Figura 9 e Figura 10 Imagens de diversos materiais misturados na demolição 101

Figura 11 Máquina demolindo a estrutura 101

Figura 12 Finalizando a demolição 102

Figura 13 Montado o equipamento 104

Figura 14 e 15 Máquina de Corte Adiamantado 104

Figura 16 Gancho para içamento Figura 17 Máquina para içar 105

Figura 18 Peça de concreto sendo retirada Figura 19 Peça transportada 105

Figura 20 Peças de concreto removidas Figura 21 Finalizando o processo 105

Figura 22 Fachada da sede do clube de Golfe 106

Figura 23 e Figura 24 Montagem da estrutura 108

Figura 25 e 26 Saguão do Clube e banheiro, ambientes onde há madeiras reutilizadas na estrutura, detalhes e mobiliários. 108

Figura 27 Planta Baixa 109

Figura 28 Corte Longitudinal 109

Figura 29 Corte Transversal 110 
Figura 30 e Figura 31 Detalhes da estrutura de madeira reutilizada 110

Figuras 32, 33 e 34 Peças de madeira reaproveitadas com marcas dos antigos encaixes 111

Figura 35 Maquete física desenvolvida pelo escritório de arquitetura 112

Figura 36 e 37 Antigo Hangar. 114

Figura 38 e 39 Cobertura do Hangar

Figura 40 e 41 Desmonte da Cobertura

Figura 42 e 43 Peças metálicas da cobertura

Figura 44 e 45 Construção do ginásio

Figura 46 e 47 Construção do ginásio 115

Figura 48 e 49 Montagem da cobertura do ginásio. 116

Figura 50 e 51 Construção do ginásio 116

Figura 52 Ginásio Pronto 116

Figura 53 Planta do ginásio 117

Figura 54 Planta do Ginásio 118

Figura 55 Vista geral da construção do protótipo 121

Figura 56 Vista interna Figura 57 Detalhe do apoio da casa e da rampa........ 122

Figura 58, 59 e 60 Peças utilizadas na fixação da estrutura 123

Figura 61 Detalhe instalações elétricas Figura 62 Resíduos 124

Figuras 63, 64 e 65 Armazenamento de peças e elementos do protótipo 125

Figura 66 Içamento de um painel Figura 67 Retirada do painel. 125

Figura 68 e Figura 69 Armazenamento do painel 126

Figura 70 e 71 Um dos painéis içados e armazenado 126

Figura 72 Ekohouse remontada para o concurso na Espanha 
Figuras 73 e 74 Interior do Protótipo

Figura 75 Madeira retirada da obra e Figura 76 gesso quebrado ........................................... 135

Figura 77 e Figura 78 Peças de concreto maciço resultado do corte da parede da eclusa ............... 136

Figura 79 e 80 Materiais reutilizados no clube de Golfe e no Ginásio .......................................... 138

Figura 81 e Figura 82 Imagens da Eko House na fase de montagem e desmontagem................... 139 


\section{GLOSSÁRIO DE TERMOS E ABREVIAÇÕES}

ABNT Associação Brasileira de Normas Técnicas

ACV Análise do Ciclo de Vida

CBIC Câmara Brasileira da Indústria da Construção

CIB Conselho Internacional da Construção (International Council for Research and Innovation in Building and Construction)

DFA Design for Assembly (Projeto para Montagem)

DFC Design for Compliance (Projeto para Conformidade)

DFD Design for Disassembly / Deconstruction (Projeto para o Desmonte / Deconstrução)

DFE Design for Environment (Projeto para o Meio-Ambiente)

DFLC Design for Life-Cycle (Projeto para o Ciclo de Vida)

DFM Design for Manufacture (Projeto para a Manufatura)

DFMC Design for Material Logistics and Component Applicability (Projeto para logística do material e aplicação de componente)

DFQ Design for Quality (Projeto para a Qualidade)

DFR Design for Reliability (Projeto para Confiabilidade)

DFS Design for Service (Projeto para o Serviço)

DFT Design for Test (Projeto para Teste)

DFX Design for $\mathrm{X}$ (Projeto para o $\mathrm{X}$ )

EOL End of Life (fim da vida útil)

FMI Fundo Monetário Internacional

IETC International Environmental Technology Center (Centro Internacional de Tecnologia do Meio Ambiente)

ISO International Organization for Standardization (Organização Internacional de Padronização)

NBR Norma Brasileira

ONU Organização das Nações Unidas

PIB Produto Interno Bruto

RCD Resíduos de Construção e Demolição 
UNEP United Nations Environment Programme (Programa das Nações Unidas para o Meio Ambiente) VUP Vida útil do Projeto 


\section{RESUMO}

\section{Arquitetura e Sustentabilidade: considerações sobre 0 Desmonte das Edificações}

Este trabalho visa discutir duas importantes fases do edifício: a concepção do projeto e o final de sua vida útil, com enfoque na arquitetura sustentável. Logo nas primeiras idealizações do edifício, quando se inicia o conceito e projeto, já é importante considerar todo o seu ciclo de vida, até mesmo a fase de desmontagem ou demolição, como é mais comum atualmente. Através da demolição são gerados muitos resíduos que, grande parte das vezes, são despejados na natureza ou em aterros sanitários sem tratamento adequado, o que traz como consequência grande poluição ambiental e desperdício. Assim este trabalho tem o objetivo de analisar e avaliar processos de demolição ou desmontagem de edificações para propor diretrizes que visam reduzir o desperdício e o impacto ambiental, através de um desmonte racionalizado, no lugar da demolição. Inicialmente foi realizada revisão bibliográfica com o intuito de analisar o que está sendo estudado sobre o assunto no Brasil e no mundo. Um dos principais temas foi o Projeto para o Desmonte, pois é um assunto novo no setor e de grande relevância que vem sendo abordado em países preocupados com o desenvolvimento sustentável. A revisão bibliográfica se baseia principalmente no Design for Disassembly, Design for " $X$ ", desenvolvimento sustentável, arquitetura sustentável, análise do ciclo de vida e o ciclo de alguns materiais, reutilização e reciclagem, além da demolição. Para análise prática, foram realizados estudos de maneira a avaliar diferentes métodos construtivos e processos de demolições ou desmonte, além das possibilidades de reutilização e reciclagem, após a vida útil dos edifícios. Estes estudos foram realizados através de observação direta, isto é, acompanhamento de alguns processos de demolição ou desmontagem, visitas a obras, entrevistas com arquitetos e demais profissionais envolvidos, além de análise de documentos. Dessa maneira foi possível verificar diversos processos e buscar diretrizes para auxiliar a aplicação do Projeto para o Desmonte e reduzir os impactos ambientais.

Palavras-chave: arquitetura sustentável, sustentabilidade, projeto para o desmonte, design for disassembly. 


\section{ABSTRACT}

\section{Architecture and Sustainability: Considerations about disassembly of buildings}

This paper aims at discussing two important phases of the building: the project design and the end of his life, focusing on sustainable architecture. In the first few idealizations of the building, when it starts the concept and design, it is important to consider the entire life cycle, even dismantling stage or the demolition, as is more common today. Through many demolition waste are generated, most times, are dumped in nature or in landfills without proper treatment, which consequently brings great environmental pollution and waste. Thus this work aims to analyze and evaluate processes demolition or dismantling of buildings to propose guidelines aimed at reducing waste and environmental impact, through a streamlined disassemble, instead of demolition. Initially literature review was performed in order to analyze what is being studied on the subject in Brazil and worldwide. A major theme was the Design for the Disassembly because it is a new subject in the field and of great importance that is being addressed in countries concerned with sustainable development. The literature review is mainly based on Design for Disassembly, Design for "X", sustainable development, sustainable architecture, analysis of the life cycle and the cycle of some materials, reuse and recycling, and demolition. For practical analysis, studies were performed in order to evaluate different methods of construction and demolition or dismantling processes, beyond the possibilities of reuse and recycling after the useful life of the buildings. These studies were conducted through direct observation, monitoring of some processes demolition or dismantling works visits, interviews with architects and other professionals involved, and document analysis. Thus it was possible to get various processes and guidelines to assist the application of Design for Disassembly and reduce environmental impacts.

Keywords: sustainable architecture, sustainability, design for dismantling, design for disassembly. 


\section{INTRODUÇÃO}

Segundo a Agenda 21 para construção sustentável em países em desenvolvimento (CIB; UNEP - IETC, 2002), os seres humanos são o foco principal do debate de desenvolvimento sustentável, pois a principal preocupação é manter as condições favoráveis para a vida tanto a nível global como local. Para a Agenda, como não compreendemos totalmente as complexas inter-relações entre os diferentes componentes da biosfera, é defendida uma abordagem prudente, daí a chamada para a conservação da biodiversidade e proteção ambiental.

O principal agente causador da degradação ambiental foi o próprio ser humano. Ao longo do desenvolvimento da sociedade houve grande crescimento demográfico e econômico, o que resultou em grande aumento de consumo e uso dos recursos naturais. Segundo Alves (2012) o consumo médio da humanidade cresceu significadamente, pois entre 1800 e 2010 a população aumentou em 7 vezes (de 1 bilhão para 7 bilhões) e a economia, aproximadamente, 50 vezes.

Alves (2012) afirma que em junho de 2012 a população mundial era de 7,1 bilhões de pessoas que utilizavam mais de $50 \%$ da capacidade de reposição da natureza e de recursos naturais. Segundo o autor, para garantir o padrão de vida atual da humanidade, em 2030, serão necessárias duas vezes a área da Terra, isso devido ao aumento da população, da produção e do consumo.

Os aspectos ambientais do desenvolvimento sustentável exigem que possamos encontrar um equilíbrio entre proteger a ambiente físico e seus recursos, e usá-los de uma forma que permitirá que a terra continue a proporcionar uma qualidade de vida aceitável para os seres humanos (CIB; UNEP - IETC, 2002). 
O acelerado crescimento populacional e do consumo acarretaram graves consequências ao meio ambiente. O tempo e a escala com que as indústrias consomem os recursos naturais e conectam diferentes materiais, que posteriormente, são despejados na Natureza, torna-se impossível a reintegração deles pelo meio ambiente (AMOÊDA, 2009). Para o autor, desde as últimas décadas, se discute uma ética ecológica, com as mudanças do clima, o crescimento da poluição e depreciação dos recursos naturais, isso fez com que se criassem novas percepções em relação ao planeta. As questões ambientais ultrapassam as fronteiras geográficas, levando à consciência de que as ações dos seres humanos afetam-no com um todo.

A população tende a crescer e se desenvolver ainda mais, assim é preciso exigir cuidados em relação à preservação do meio ambiente. Segundo a ONU, a população deve atingir entre 8 a 10 bilhões de pessoas, em 2050, e segundo o FMI, a economia mundial deve crescer acima de 3,5\%, neste período (Alves, 2012). Portanto é necessário buscar maneiras para tornar o desenvolvimento mais sustentável, para que o planeta suporte tamanho crescimento.

Hoje em dia se busca recuperar os materiais para evitar a exaustão dos recursos naturais, a ecologia industrial reconhece as buscas pela diminuição dos resíduos e aumento da recuperação de materiais e componentes por meio de reutilização ou reciclagem (AMOÊDA, 2009).

Para Tessaro, Sá et al. (2012) a construção civil é um dos setores mais importantes para o desenvolvimento da sociedade, no entanto, gera graves impactos ambientais, pois altera o meio ambiente através do grande consumo de matéria prima e geração de resíduos, assim, ao longo da última década se intensificou a preocupação com estas questões. 
Segundo a agenda 21 para construção sustentável em países desenvolvidos (CIB; UNEP-IETC, 2002), a questão dos resíduos da construção e demolição é muito importante, pois quando sua disposição não é controlada, são depositados ilegalmente em barragens, rios, cursos ou qualquer lugar disponível, que podem se tornam criadores de mosquitos e parasitas.

O Setor da construção civil é um dos maiores responsáveis pelo impacto ambiental. Segundo Edwards e Bennett (2003) o setor é responsável por cerca de $50 \%$ dos materiais extraídos da natureza e $50 \%$ total dos resíduos. Isso gera uma quantidade enorme de resíduos e desperdício de materiais.

Além disso, no ultimo século houve grande desenvolvimento, aliado a uma explosão demográfica, que fez com que houvesse um grande aumento da demanda de matérias primas. Somente em 2010, a receita com venda de materiais de construção cresceu 12,14\%, no mercado interno (WESTPHALEN, 2011). Segundo o CBIC (Câmara Brasileira da Indústria da Construção, 2011) o crescimento do setor foi acima de $11 \%$, no mesmo ano, o maior resultado nos últimos 24 anos.

No setor da construção civil também está sendo bastante discutido o tema da sustentabilidade, pois a construção consome grande quantidade de recursos naturais e gera muitos resíduos. Para Soares, Souza e Pereira (2006) a construção civil tem bastante impacto na economia de um país, assim algumas alterações nas diferentes etapas do processo construtivo podem contribuir com redução de custos e diminuir impactos causados ao meio ambiente.

O desenvolvimento do projeto é uma etapa muito importante que pode contribuir com a redução do impacto ambiental no setor, pois pode minimizar o consumo de matérias primas e geração de resíduos. As principais preocupações em relação ao projeto eram 
resolver aspectos técnicos e funcionais, de maneira a agradar o consumidor final, no entanto, atualmente, devido aos problemas ambientais que estamos enfrentando, outra abordagem tem sido palco de discussões, que são as questões sustentáveis em relação ao meio-ambiente (GOUVINHAS; ROMEIRO FILHO, 2010).

Além disso, compete ao profissional tomar decisões que contribuam com o desenvolvimento sustentável. Hoje em dia, cabe ao projetista buscar soluções, ainda na fase de concepção do projeto, para reduzir os impactos causados à Natureza, isso pode ser feito através de definições de materiais e sistemas de produção utilizados na fabricação, e há a possibilidade de selecionar meios menos danosos (GOUVINHAS; ROMEIRO FILHO, 2010).

Algumas ferramentas foram desenvolvidas para auxiliar os profissionais. Atualmente, em vários ramos industriais, assim como na indústria da construção civil, está sendo debatida a questão do Design for Environment (Projeto para o meio-ambiente), que envolve várias etapas do design com o objetivo de tornar o produto mais sustentável (KLOHN; FERREIRA, 2009).

Para o desenvolvimento de um produto sustentável é importante considerar o ciclo de vida completo e os materiais utilizados. Gehin, Zwolinski e Brissaud (2007) afirmam que a Análise do Ciclo de Vida é uma ferramenta que vem crescendo para verificar com mais precisão os impactos dos produtos no meio ambiente. A construção sustentável implica em um pensamento holístico que respeita a construção e gestão, assumindo uma perspectiva de ciclo de vida (CIB; UNEP - IETC, 2002). O fim da vida útil também é uma etapa essencial que deve ser analisada, pois o descarte correto, reciclagem ou reutilização, podem minimizar a poluição. 
Com a intenção de buscar um desenvolvimento sustentável, novas tecnologias e maneiras de construir estão sendo desenvolvidas, com o objetivo de facilitar a desconstrução do edifício após sua vida útil, de maneira a reaproveitar melhor seus materiais e componentes, com a intenção de reduzir a quantidade de entulho gerada.

Empresas, em todo o mundo, estão conscientes de que é necessário encontrar alternativas para tratar os insumos produzidos, com o propósito de reduzir o impacto ambiental, assim a preocupação com a recuperação dos materiais é importante para evitar a exaustão dos recursos naturais, mesmo nas indústrias busca-se amenizar os impactos ambientais, através da reutilização e reciclagem (AMOÊDA, 2009). Para o autor, nas atividades de construção, também está iniciando a consciência da importância de recuperar os materiais, portanto novas abordagens começam a ser tomadas, como a Concepção de Projeto que considera a Desconstrução.

O Projeto para o Desmonte ou Desconstrução é um conceito utilizado em algumas indústrias que atualmente começa a ser discutido na indústria da construção civil. É uma das variáveis do Projeto para "X" e "Projeto para o Meio-Ambiente", que contribui com o desenvolvimento sustentável, como será discutido ao longo deste trabalho.

O Projeto para o Desmonte é uma importante ferramenta que contribui com a redução do impacto ambiental do setor, pois contribui com a redução da quantidade de resíduos e economia de recursos naturais. Este conceito relaciona duas etapas importantes da construção: a concepção do projeto e o fim da vida útil da edificação. Assim pode contribuir de maneira significativa para o desenvolvimento sustentável no setor.

Além disso, é uma alternativa para a Demolição. $\mathrm{O}$ ato de destruir um edifício e colocar abaixo, como é feito atualmente, gera diversos resultados negativos. Esta prática gera 
terríveis consequências ao meio ambiente, pois produz muitos resíduos, desperdiça materiais, assim é importante procurar estratégias para reduzir isso e facilitar a reutilização e reciclagem (HERIQSON; ROCHA; SATTLER, 2008).

O Projeto para o Desmonte pode oferecer alternativas. Hoje em dia, os edifícios são projetados e construídos com grande desperdício de materiais e grande consumo de matérias primas que resultam em danos ambientais (GORGOLEWSKI, 2008).

Assim é importante buscar opções para a Demolição que podem ser desenvolvidas na concepção do projeto, com objetivo de reduzir o alto impacto ambiental produzido pelo setor. Além disso, é importante considerar todo o ciclo dos materiais, componente e da própria edificação, a fim de obter melhores resultados.

\subsection{Objetivos da Pesquisa}

O trabalho tem como objetivo analisar duas fases importantes, que estão diretamente ligadas, na construção do edifício: a concepção do projeto e a desmontagem, evitando que a única solução no fim da vida útil da construção seja a demolição. Além disso, serão avaliadas maneiras para que soluções previstas em projetos contribuam para a reutilização e reciclagem de materiais e componentes das edificações.

Além disso, serão propostas diretrizes, baseadas nas informações adquiridas e analisadas ao longo do trabalho, para a aplicação do Projeto para o Desmonte no desenvolvimento de projetos arquitetônicos.

Objetivos Específicos:

- Contextualizar o conceito do Projeto para o Desmonte aplicado na construção civil; 
- Analisar a importância do projeto de arquitetura em considerar o processo de desmonte do edifício, de maneira a aumentar a vida útil dos materiais empregados.

- Discutir sobre o ciclo de vida dos materiais, com enfoque na sua fase final do edifício, enfatizando a importância de melhor aproveitá-los e prolongar sua vida útil;

- Analisar obras que reutilizaram materiais, com diferentes métodos construtivos;

- Verificar as possibilidades de Desmonte e Reutilização;

- Avaliar como essas medidas podem amenizar os impactos ambientais causados pela construção civil.

\subsection{Justificativa}

Para que seja possível construir de maneira mais sustentável e consciente, todo o processo da edificação, além do ciclo de vida, manutenção, análise dos materiais e componentes, devem ser considerados desde a fase inicial do projeto de arquitetura. No Brasil ainda há poucas pesquisas focadas na fase final do ciclo de vida dos edifícios, após a sua vida útil, mas o interesse neste tema está aumentado devido aos benefícios que podem ser obtidos.

Apesar de a desconstrução ser um assunto novo, tem atraído um interesse crescente, pesquisas em Projeto para a Desmontagem estão tomando lugares em muitas universidades e empresas em toda a Europa e América do Norte (THORMARK, 2001).

Para Rocha e Sattler (2009) na reforma e demolição de edifícios é importante buscar técnicas de desconstrução para facilitar a reutilização dos materiais, dessa maneira é possível reutilizar partes funcionais e componentes como tijolos, janelas, revestimentos, diferente da demolição, onde grande parte dos materiais se torna resíduos. 
Para Couto, Couto e Teixeira (2006) a desconstrução valoriza a reutilização de elementos e materiais que seriam tratados como resíduos, sem valor e depositados em locais que muitas vezes não são voltados para esses fins. Além disso, possibilita a reutilização de materiais, reciclagem, inovação de tecnologia, sustentabilidade, além do nascimento de um novo mercado: o de materiais usados e com benefícios econômicos e ambientais.

O descarte é uma das etapas de grande importância, pois as questões projetuais da desmontagem de um produto permitem que seus componentes e materiais sejam descartados de maneira mais adequada, facilitando e possibilitando novos usos e reciclagem (KLOHN; FERREIRA, 2009).

A questão dos resíduos sólidos é um grande problema ambiental que gera graves consequências ao meio ambiente, portanto é imprescindível buscar maneiras para mitigar a situação. Diariamente, nas áreas urbanas são geradas enormes quantidades de entulhos que se faz necessário estabelecer um modelo de gerenciamento sustentável de resíduos (ANDERE; SANTOS, 2010).

Para Rocha e Sattler (2009) a indústria da construção civil é uma das maiores consumidoras de recursos naturais e geração de resíduos, assim é muito importante mudar algumas atitudes, como melhorar o reaproveitamento de materiais $\mathrm{e}$ reciclagem, em busca de padrões mais sustentáveis.

A reciclagem de resíduos é uma opção importante, pois contribui para a diminuição da grande quantidade que são despejadas na natureza. No entanto, deve ser considerando os efeitos dos detritos gerados após a utilização dos materiais, que já foram reciclados, sem esquecer que um dia eles também vão ser descartados ou reciclados novamente. 


\begin{abstract}
"A reciclagem de resíduos deve ser abordada de forma sistêmica, pois trata-se de um problema complexo com muitas variáveis. Para a aplicação de um resíduo no mercado é necessário pesquisá-lo cientificamente, conhecer seu risco de contaminação e encontrar para ele aplicações potenciais, levando em consideração sua qualidade, limitações e aspectos técnico-econômicos que o cercam. Assim, faz-se necessário estudar atentamente as consequências da utilização dos materiais reciclados, o ciclo de vida, e como será solucionada a questão dos resíduos gerados por eles." (Ângulo, 2000).
\end{abstract}

Assim, o Projeto para o Desmonte se torna uma ferramenta importante. Para Klohn e Ferreira (2009) este conceito é muito importante para diminuir os danos ambientais causados pela fabricação de produtos, pois possibilita a sua manutenção, reutilização e reparação, de maneira a prolongar sua vida útil. Além disso, para os autores, os materiais que podem ser facilmente separados são mais fáceis de serem reutilizados, sem novos processamentos, ou reciclados, ou isolados para melhor disposição final junto à natureza.

Para Manzini e Vezzoli (2008) quando o projeto considera esta importante fase do ciclo de vida do produto contribui para melhor aproveitamento do desmonte. Para os autores, o projetista não pode impor seus princípios aos clientes, mas deve fornecer alternativas, soluções para problemas técnicos, estimular a imaginação e orientar, de maneira a oferecer propostas mais sustentáveis.

Levando em consideração que o projeto é o ponto de partida de um edifício, se espera que grande parte das soluções minimizadoras dos prejuízos ambientais seja de iniciativa dos arquitetos, que são responsáveis por estas etapas (DEGANI; CARDOSO, 2002). 
Além disso, para Klohn e Ferreira (2009) o designer tem a capacidade e o dever de desenvolver projetos economicamente viáveis, considerando o ciclo de vida dos produtos e prever critérios ecológicos do início ao fim de sua vida útil.

É importante repensar a maneira de se projetar para obter melhores resultados na redução de resíduos. Adotar princípios de racionalização da construção e coordenação modular pode contribuir. Alguns arquitetos e engenheiros buscam inserir este conceito, no entanto, os empresários ainda tendem a utilizar técnicas convencionais, que geram muito desperdício (MEIRA; MELO, 2012). Repensar a maneira de projetar e construir pode contribuir com a redução de resíduos tanto na construção quanto no desmonte da edificação.

As possíveis formas de reciclagem no futuro são determinadas, principalmente, na fase de concepção do produto (THORMARK, 2001). Assim é imprescindível considerar todas as fases do ciclo de vida da edificação, de seus materiais e componente, no desenvolvimento do projeto.

\section{$1.3 \quad$ Método de pesquisa}

O desenvolvimento da pesquisa se iniciou através das coletas de dados, principalmente bibliográficos. Através de livros, teses e artigos científicos, onde foi estudada a relação entre o projeto do edifício e o fim do seu ciclo de vida.

Além disso, foram realizados cinco estudos empíricos para analisar as dificuldades e barreiras no reaproveitamento dos materiais. Dois destes estudos, Eko house e Demolição Convencional, são considerados estudos de caso enquanto que os outros auxiliaram no desenvolvimento da pesquisa com caráter exploratório. 
Portanto, também serão apresentados dois estudos sobre reutilização de materiais onde um predomina estrutura de madeira, e no outro, estrutura metálica. Além disso, será apresentado um caso de Demolição Programada, uma técnica para se adaptar à falta de planejamento do processo de desmonte nos projetos de arquitetura.

Nesta pesquisa o objetivo principal foi estudar o conceito do Projeto para o Desmonte na indústria da construção civil. Atualmente não é comum que os projetistas considerem este conceito no desenvolvimento do projeto, como veremos na revisão bibliográfica e através de entrevistas. Além disso, no tempo do desenvolvimento do mestrado (de dois a três anos) não seria possível acompanhar o projeto, depois a construção e futuramente a desmontagem de uma edificação.

Assim, foram realizados diversos estudos, nos quais foram selecionados os casos mais pertinentes para a pesquisa, com o objetivo de analisar características que possam contribuir com o desmonte.

Finalmente, com vários dados coletados nos estudos e na revisão bibliográfica, foram propostas diretrizes para auxiliar a aplicação do Projeto para o Desmonte, no setor da construção civil. Também são apresentados checklits para tornar mais prática a aplicação dos conceitos abordados nas diretrizes. Por fim são apresentadas as conclusões e sugestões para futuros trabalhos.

\subsection{Delineamento da pesquisa}

\subsubsection{Levantamento e Revisão Bibliográfica}

O objetivo foi procurar referências sobre desenvolvimento sustentável, posteriormente voltada para o setor da construção civil e depois pesquisas voltadas ao Projeto para o 
Desmonte e tudo aquilo que o envolve, como análise do ciclo de vida, projeto do produto, pesquisa de materiais, demolição, resíduos, entre outros.

Foi realizada intensa pesquisa em livros, teses, dissertações, artigos, entre outros, para obter ampla informação sobre o tema abordado neste trabalho. Assim foi possível reunir informações sobre Projeto para o Desmonte, Projeto para $X$, Arquitetura Sustentável, Reutilização, Reciclagem, Análise do Ciclo de Vida e demais temas abordados.

Com a análise das informações obtidas através da pesquisa bibliográfico, foi possível escolher estudos empíricos para analisar como estes assuntos são abordados na prática.

\subsubsection{Pesquisa Descritiva - Estudo de Campo}

\subsubsection{Definição dos Estudos}

Para o desenvolvimento deste trabalho foram realizados cinco estudos empíricos. Dois deles são classificados como estudos de caso (Demolição Convencional e Eko House) e os outros três (Demolição Programada, Reutilização de Estrutura de Madeira e Reutilização de Estrutura Metálica) são classificados como estudos exploratórios. A principal diferença entre eles é que nos Estudos de Caso foi possível acompanhar o processo, enquanto que nos outros foram reunidas informações depois que o procedimento foi concluído.

A escolha dos estudos foi definida devido às necessidades de avaliar questões a serem debatidas que pudessem favorecer o desmonte ao invés da demolição. Além disso, 
foram analisadas situações onde ocorre a reutilização de materiais, para analisar as possibilidades e dificuldades, mesmo quando não há previsões para o desmonte.

Como mencionado anteriormente, limitada pela falta da aplicação do conceito do Projeto para o Desmonte atualmente e também pelo tempo da pesquisa, foi necessário buscar diversos estudos onde foi possível observar características que podem fornecer diretrizes e contribuir com o desenvolvimento desta ferramenta no setor da construção civil.

Assim os cinco estudos tem características diferentes, no entanto, complementares. Dessa maneira contribuíram com a abordagem de diversas maneiras sobre o tema e ajudou a explorar diferentes opções e soluções.

Foram pesquisadas obras de até $2.500,00 \mathrm{~m}^{2}$, com exceção do estudo sobre Desmontagem Programada, pois não é muito comum em construções menores. Não foram estudadas obras de grandes portes, com áreas maiores, pois o objetivo foi se aproximar da realidade da região, onde a grande maioria das construções atinge esta área.

O primeiro a ser apresentado é um estudo de caso, onde foi acompanhada uma Demolição considerada Convencional de um edifício comercial, localizado em Ribeirão Preto-SP. Foi possível observar o que pode ser removido sem ser invalidado e o que foi descartado como resíduo. Algumas partes foram desmontadas, como o telhado e alguns elementos da fachada para futura revenda e reutilização. Foi possível observar o que pode ser desmontado e reaproveitado e o que foi recolhido apenas como entulho, além de analisar porque isto ocorre atualmente. Foram realizadas entrevistas com algumas pessoas envolvidas na demolição, além do acompanhamento da demolição e desmontagem. 
O segundo é estudo exploratório sobre Desmontagem Programada que demonstra a necessidade de desenvolver novas tecnologias que se adaptem ao fato dos projetistas não considerarem a desmontagem das edificações. Neste caso foi necessária remover uma grande parede de concreto de uma barragem com a técnica de fio adiamantado. As informações e imagens foram fornecidas pelo engenheiro da empresa que realizou a desmontagem, através de entrevista.

O terceiro estudo foi um projeto desenvolvido com a intenção de reaproveitar madeiras de antigas tulhas de café. Dessa maneira foi possível analisar como foi o desenvolvimento do projeto e da obra, além dos resultados quando um dos principais conceitos do projeto é reaproveitar os materiais. Neste caso, quando foram construídas as tulhas, não foi previsto seu desmonte, mesmo assim, foi possível reutilizar grande parte dos materiais. Também foi possível reaproveitar telhas e tijolos cerâmicos. Foram realizadas entrevistas com o arquiteto do projeto, o administrador do clube, visitas ao local e reunião de fotos e documentos da obra.

No quarto caso houve o reaproveitamento da estrutura metálica de um antigo hangar que foi utilizada no ginásio poliesportivo, no campus da USP-SC, este caso foi importante para analisar os diferentes resultados obtidos com o reaproveitamento da estrutura. A reutilização tornou a construção financeiramente possível e também economizou tempo. Foi realizada entrevista com a arquiteta da prefeitura do campus que participou do projeto, visitas ao local e reunião de fotos e documentos sobre a obra. As informações deste estudo, também de carácter exploratório.

Por fim, será apresentado o estudo de caso sobre a Eko House, um projeto que é um protótipo de uma residência que foi construído no campus da USP - SP, com conceitos sustentáveis, e foi desmontado e remontado na Espanha, onde participou 
de um concurso de residências sustentáveis. Neste estudo vários conceitos puderam ser observados, principalmente o desmonte de uma edificação que incluiu o conceito desde o desenvolvimento do projeto. Neste caso, foram feitas visitas ao canteiro, além de entrevistas com uma das professoras responsável, alguns estudantes e operários.

Estes estudos empíricos foram realizados para aproximar a revisão bibliográfica à prática, de maneira a analisar os conceitos estudados e acompanhar o que está acontecendo atualmente no setor. Assim, foi possível analisar as barreiras para o Desmonte e propor diretrizes para o desenvolvimento do projeto e facilitar a desmontagem. Todo o processo será mais bem detalhado nos capítulos 4 e 5 .

\section{Análise dos dados}

Após a realização dos estudos de caso, foi possível fazer avaliações que foram confrontadas com as informações da revisão bibliográfica, com o objetivo de analisar as dificuldades e os benefícios de se aplicar o conceito do Projeto para o Desmonte no setor da Construção Civil.

Foram analisados dados das revisões bibliográficas, assim como dos estudos de casos e exploratórios, para que fosse possível fornecer diretrizes para aplicação do conceito, um checklist de verificação de projetos quanto a facilidade de desmonte das soluções adotadas e conclusões sobre a pesquisa realizada.

\subsubsection{Diretrizes}

Com a análise de dados sobre a Revisão Bibliográfica e os Estudos Empíricos, foi possível reunir informações para propor diretrizes para o desenvolvimento do Projeto para o Desmonte. Além disso, foram criados dois checklists para tornar a aplicação do conceito mais prático e objetivo, que se encontrar nos anexos. 


\subsubsection{Estrutura da Dissertação}

A dissertação encontra-se estruturada em sete capítulos.

O Capítulo 1 traz a introdução ao trabalho, onde se apresentam brevemente o tema central da pesquisa, os objetivos a serem alcançadas, a justificativa da escolha do tema, a estratégia e o delineamento da pesquisa.

O Capítulo 2 aborda uma revisão bibliográfica sobre o conceito de desenvolvimento sustentável na construção civil, voltado para o meio ambiente, pois é o vertente que está mais relacionada ao tema estudado. Além disso, aborda os temas da Análise do Ciclo de Vida e Resíduos. As questões discutidas neste capítulo são fundamentais para a compreensão e desenvolvimento do conceito do Projeto para o Desmonte, que será apresentado no próximo capítulo.

No Capítulo 3 consta uma breve revisão bibliográfica sobre o conceito do Projeto para "X" (Design for X) e mais detalhada sobre o Projeto para o Desmonte (Design for Disassembly), nas indústrias em geral e no setor da construção civil, como uma ferramenta para o desenvolvimento de projetos mais sustentáveis.

O Capítulo 4 é sobre os materiais e métodos de pesquisa utilizados e reunidos nos estudos empíricos. Nele serão detalhadas as informações obtidas, o processo e explicações sobre as definições dos estudos.

O Capítulo 5 traz os dos dados levantados nos estudos de campo realizados. São apresentados dois estudos de caso e outros três de carácter exploratórios, que contribuem com questões importantes relacionadas ao Projeto para o Desmonte no setor da construção civil. Posteriormente são apresentadas as análises dos dados referentes aos estudos 
No Capítulo 6 são apresentadas as diretrizes para a aplicação do conceito do Projeto para o Desmonte, com base no que foi analisado na revisão bibliográfica e nos estudos de campo.

Por fim, no Capítulo 7, são apresentadas as conclusões relacionadas à revisão bibliográfica e os estudos analisados, além de sugestões para novos trabalhos.

Posteriormente serão apresentadas as Referências Bibliográficas que foram usadas no desenvolvimento deste trabalho.

Finalmente, o Anexo, com entrevistas, questionários e demais informações relevantes que são utilizadas ao longo da dissertação. 


\section{ARQUITETURA E SUSTENTABILIDADE}

O projeto de arquitetura pode contribuir de maneira significativa com 0 desenvolvimento sustentável, principalmente ligado às questões ambientais. Desde a primeira conferência realizada pelas Nações Unidas, em Estocolmo, em 1972, o tema ambiental vem sendo amplamente abordado e, posteriormente, em 1987, ficou ainda mais evidente, com o relatório "Nosso Futuro Comum" que abordou o conceito de desenvolvimento sustentável (SERRADOR, 2008).

Uma das primeiras conferências internacionais focadas no desenvolvimento sustentável foi realizada no Rio de Janeiro em 1992. Na Conferência das Nações Unidas sobre o Meio Ambiente e Desenvolvimento Humano, que também ficou conhecida como Cúpula da Terra ou ECO-92, foram assinados cinco documentos importantes para o desenvolvimento sustentável, entre eles a Agenda 21, que foi aprovada por 170 países e definia compromissos entre governo e sociedade para o planejamento estratégico universal (SERRADOR, 2008).

Para o autor, em 1992, vários países do Norte e do Sul se uniram na Conferência das Nações Unidas sobre o Meio Ambiente e Desenvolvimento, onde foram tratadas várias questões sobre a preservação do meio ambiente e o desenvolvimento econômico. Este foi um marco importante que demonstra a busca por mudanças de atitudes para obter um desenvolvimento mais sustentável.

Em 1994, a discussão sobre o assunto atingiu de maneira mais direta o setor da construção civil, através da primeira conferência centrada na eficiência energética das edificações, organizada pelo CIB (International Council for Research and Innovation in Building and Construction), em Tampa (SERRADOR, 2008). 
Em 2002, o CIB e a UNEP desenvolveram a Agenda 21 voltada para a Construção Sustentável em Países em Desenvolvimento (SERRADOR, 2008). Assim tornou-se mais evidente a necessidade de programar melhor as construções e contribuir com o desenvolvimento sustentável.

A Agenda 21 para construção sustentável em países em desenvolvimento (CIB; UNEP IETC, 2002) considera que a "Construção sustentável implica num pensamento holístico no que respeita à construção e gestão do ambiente construído, assumindo uma perspectiva de ciclo de vida". Para a Agenda, a construção sustentável, não trata apenas de projetos que tenham orientações ambientais, mas que também tenham operações e procedimentos de manutenção compatíveis ao meio ambiente, além dos materiais de construção e componentes que devem ser produzidos de forma sustentável e deve corresponder às exigências ambientais.

Em junho de 2012, no Rio de Janeiro, aconteceu a Conferência das Nações Unidas sobre Desenvolvimento Sustentável, a Rio+20. Foram 50.000 visitantes, delegações de 190 países e diversas ONGs que vieram discutir maneiras de conciliar o desenvolvimento, a qualidade de vida, sem degradar o meio-ambiente (JIMENEZ; ARINI, 2012). Estes números demonstram o crescente interesse no assunto e o empenho de buscar novas soluções.

Para Jimenez e Arini (2012) em todo o mundo empresas buscam comercializar produtos que não agridam tanto ao meio ambiente, motivados por consumidores que exigem esta postura. A sociedade demanda cada vez mais medidas públicas que contribuam com a redução de poluição dos rios, oceanos e lixo urbano.

Segundo a agenda 21 para construção sustentável em países desenvolvidos (CIB; UNEP-IETC, 2002), as altas taxas de consumo de materiais, que muitas vezes são 
inapropriados e contribuem com a grande quantidade de lixo gerado, pois são desperdiçados por não serem necessários aos edifícios ou são usados em maior quantidade que o necessário. Para John (2000) o setor gera grande quantidade de resíduos, além de ser um dos que mais consomem matéria prima e energia, isso também faz com que contribua para a poluição ambiental e o efeito estufa.

Assim, em diversas áreas se discute o desenvolvimento sustentável e preservação do meio-ambiente. Considerar as características dos materiais, sua durabilidade e manutenção na fase de projeto, contribui significadamente na redução de resíduos e desperdícios.

Para Gouvinhas e Romeiro Filho (2010) várias questões ambientais e sustentáveis estão sendo discutidas na fase de projeto, pois é importante que os projetistas busquem soluções para os impactos naturais causados pelo setor.

Muitas decisões tomadas na fase do desenvolvimento do projeto contribuem significadamente para o desenvolvimento sustentável no setor. Seleção de materiais, conexões e sistemas construtivos são extremamente importantes para obter melhores resultados. Até mesmos os selos que classificam as construções sustentáveis analisam a escolha dos materiais e sistemas. Para Edwards e Bennett (2003) a seleção cuidadosa de produtos também é uma exigência de selos verdes, como o BREEAM ${ }^{1}$ e o LEED². Também outros selos como o $\mathrm{HQE}^{3}, \mathrm{AQUA}^{4}$ analisam esta questão ${ }^{5}$.

\footnotetext{
${ }^{1}$ BREEAM é um importante método de avaliação ambiental, do Reino Unido, para classificação de edifícios, com 200.000 edifícios avaliados e certificados e mais de um milhão registrados para avaliação, desde que foi lançado em 1990 (www.breeam.org, acesso 05/03/2013).

${ }^{2}$ O LEED (Leadership in Energy and Environmental Design) e um selo para certificação e orientação ambiental, criado pelo US Green Building Counsul (www.gbcbrasil.org.br, acesso 05/03/2013).
} 
Algumas decisões tomadas na fase de projeto como escolha de materiais e sistemas construtivos, podem contribuir para melhor reaproveitamento de materiais no futuro. Formoso et al. (2002), em um artigo onde são analisadas as principais causas de desperdícios nas construções residenciais no sistema mais comum no Brasil (aço, concreto pré-misturado, cimento, areia, argamassa, cal, blocos e tijolos cerâmicos), relata que as principais são: problemas de gestão nas fases anteriores à construção, falta de coordenação modular no projeto, integração de sistemas e subsistemas, detalhamento de projetos, otimização do usos de recursos, especificações imprecisas dos componentes, planejamento de layout, erros na aquisição, entrega e distribuição dos materiais. Medidas que se fossem mais bem estudadas durante o projeto, poderiam obter melhores resultados.

Dessa maneira, várias questões devem ser analisadas para contribuir com o desenvolvimento sustentável no setor, muitas delas na fase de concepção do projeto. Uma importante ferramenta é a Análise do Ciclo de Vida, um tema que quando levado em consideração desde o início pode trazer contribuições, pois é considerada em todas as etapas do produto.

\subsection{Análise do Ciclo de Vida (ACV)}

A ACV é uma importante ferramenta que deve ser incorporada na concepção do projeto para que se obter melhores resultados. Para Soares, Souza e Pereira (2006) a

\footnotetext{
${ }^{3}$ O HQE (Haute Qualité Environnementale) é uma certificação desenvolvido na França, seus conceitos se baseiam em princípios sobre desenvolvimento sustentável ditados pela Conferência das Nações Unidas (http://greenpedia.greenvana.com, acesso 07/11/2013).

${ }^{4}$ O AQUA (Alta Qualidade Ambiental) é uma certificação brasileira concedida pela Fundação Vanzolini (http://www.vanzolini.org.br, acesso 07/11/2013).

${ }^{5} \mathrm{O}$ presente trabalho não tem o objetivo de se aprofundar nas questões nos selos verdes, mas são citados para demonstrar os esforços em tornar a construção mais sustentável.
} 
Avaliação do Ciclo de Vida (ACV) é uma importante ferramenta para análise e escolha de alternativas, pois através de um inventário é possível avaliar as repercussões ambientais de uma atividade ou produto. Assim se torna mais fácil identificar e localizar mudanças que tragam benefícios ambientais.

Para Rocha e Sattler (2009) os desperdícios gerados pelo setor têm graves consequências ambientais, sociais e econômicas, assim é essencial buscar alternativas que contribuam para o fechamento do ciclo de produção, onde os materiais podem ser reutilizados e reciclados, e assim, favorecer o desenvolvimento sustentável. Portanto a ACV é uma importante ferramenta que pode ser utilizada pelos projetistas e colaborar com o processo.

A norma ABNT NBR ISO 14044 define ciclo de vida como "estágios consecutivos e encadeados de um sistema de produto, desde a aquisição da matéria-prima ou de sua geração a partir de recursos naturais até a disposição final." A norma define avaliação do ciclo de vida (ACV) como "compilação e avaliação das entradas, saídas e dos impactos ambientais potenciais de um sistema de produto ao longo de seu ciclo de vida." A norma considera que o estudo de ACV deve ser composto por quatro fases: definição de objetivo e escopo, análise do inventário, avaliação de impactos e interpretação.

Segundo a norma ABNT NBR ISO 14044 o estudo de ACV pode ser realizado em toda a vida útil do produto, desde a aquisição de matérias-primas, produção, uso, tratamento pós-uso, reciclagem até a disposição final. No entanto pode estar focado em apenas uma dessas etapas.

Para Soares, Souza e Pereira (2006) " A ACV consiste na análise e na comparação dos impactos ambientais causados por diferentes sistemas que apresentam funções 
similares." Para os autores a aplicação do ACV geralmente está aliada aos processos de tomadas de decisões nos setores empresariais e industriais, além de ser considerada muito importante na construção civil. Isso ocorre devido ao grande impacto ambiental gerado por diversas etapas do processo construtivo, desde a extração de matérias primas, até a demolição do edifício.

Conforme Edwards e Bennett (2003-tradução nossa) "ACV é um método para avaliar os impactos ambientais de um sistema, considerando todo o seu ciclo de vida, do berço ao túmuld". Para os autores é uma ferramenta padrão para medir os impactos ambientais dos materiais de construção é a análise do ciclo de vida.

No entanto, a ACV é mais utilizada nas linhas de produções do que no setor da construção civil, há vários motivos para que isso ocorra. Para Soares, Souza e Pereira (2006) a utilização da ACV no setor da construção civil apresenta algumas limitações, quando comparada ao setor industrial, pois há dificuldade em obter bases de dados e informações confiáveis. Além disso, para os autores, é muito difícil quantificar os impactos ambientais na fase de construção e demolição, também há grande variedade e composição química dos materiais, além de alterações e renovações dos espaços arquitetônicos e meios urbanos.

A Análise do Ciclo de vida evoluiu bastante ao longo dos anos. Para Guinée et al (2011), de maneira geral, a ACV desenvolveu-se a partir de análises do consumo de energia para análises ambientais mais abrangentes na década de 1970, nos anos 1980 e 1990 foram introduzidas as análises relacionadas aos custos e em 1990 a 2000, as análises sociais.

Os autores dividem o histórico da análise ciclo de vida em três partes: passado, presente e futuro. No passado, entre 1970 e 1990, o autor classifica a "década das 
concepções", pois foi quando se iniciaram os estudos sobre o tema. Inicialmente os assuntos mais discutidos foram recursos, eficiência energética, poluição e resíduos sólidos. Entre 1990 e 200 foi a "década da padronização" com surgimento de ISOs e Handbooks que buscavam uniformizar os estudos, através de métodos e procedimentos, no entanto a própria ISO reconhece que não há apenas uma maneira se realizar o ACV.

Para Guinée et al (2011) no presente, está havendo maior atenção em relação à ACV. Para os autores, atualmente há incentivos governamentais nos EUA, com a criação de maiores iniciativas da UNEP (United Nations Environment Programme) e SETAC (Society for Environmental Toxicology and Chemistry).

Nota-se o esforço em organizar a ACV, medidas estão sendo tomadas para facilitar o entendimento das análises e possíveis comparações. Uma dessas medidas é a criação da ISO 14.044 que é utilizada em vários países. Guinée et al (2011) afirma que entre 2000-2010 pode ser considerada a "década da elaboração". Enquanto a demanda de ACV aumentava, também cresciam as divergências de métodos. Diferentes abordagens foram tomadas, nem mesmo o ISO tinha a intenção de impor apenas uma forma de estudo.

A ACV pode passar por modificações e até mesmo ter outros enfoques no futuro. Para Guinée et al (2011) a ACV, entre 2010 e 2020, será a década da Análise Sustentável do Ciclo de Vida. O LCSA abordará diferentes questões em diferentes níveis do produto de maneira a considerar o planeta, a população e a prosperidade. Assim, para os autores, a LCA (Life Cycle Analysis - Análise do Ciclo de Vida) se desenvolveu para LCSA (Life Cycle Sustainability Analysis - Análise Sustentável do Ciclo de Vida) que envolve mais questões ligadas ao meio ambiente. Os autores consideram que a elaboração do LCSA é um grande desafio para a comunidade científica e governos 
internacionais, que devem estar integrados para que não se tenha, novamente, abordagens diferentes, mas que podem ser vinculadas.

A Comissão Europeia criou o CALCAS (Co- ordination Action for innovation in Life Cycle Anbalysis for Sustainability), em 2006, para estruturar melhor as diferentes abordagens de ACV. Um dos resultados foi o desenvolvimento do conceito de Análise Sustentável do Ciclo de Vida, que analisa questões voltadas para a sustentabilidade (GUINÉE et AL; 2011).

Gehin, Zwolinski e Brissaud (2007) afirmam que até pouco tempo, os produtos deveriam satisfazer e criar necessidades, no entanto, atualmente, com a explosão demográfica e o aumento do padrão de vida, e como consequência do comportamento humano, é necessário considerar os impactos ambientais dos produtos e todo o seu ciclo de vida.

Para Soares, Souza e Pereira (2006) apesar das limitações do setor em relação à aplicação da ACV, ainda assim, é uma ferramenta que contribui na fase de especificação de materiais como o objeto de promover melhorias ambientais e até mesmo econômicas, em diversas fases do ciclo.

No entanto, é necessário analisar todas as características da ACV quando se busca tomar medidas sustentáveis. Soares, Souza e Pereira (2006) citam um exemplo em que o Estado da Califórnia, nos EUA, foi o primeiro estado americano a utilizar veículos elétricos, para diminuir os impactos ambientais causados pelos motores tradicionais à combustão. Porém, é necessário avaliar como realmente esta medida contribuiu para o meio ambiente, pois a energia elétrica utilizada vem, grande parte, de combustíveis fósseis. Assim a medida desviou o foco, mas pode não ter contribuído significadamente com o objetivo inicial. 
Dessa maneira a ACV deve considerar todo o ciclo, inclusive relacionar as entradas e saídas para que possa ser mais bem aproveitado. Na figura 01 é possível perceber melhor como o que deve ser analisado ao longo do desenvolvimento da análise.

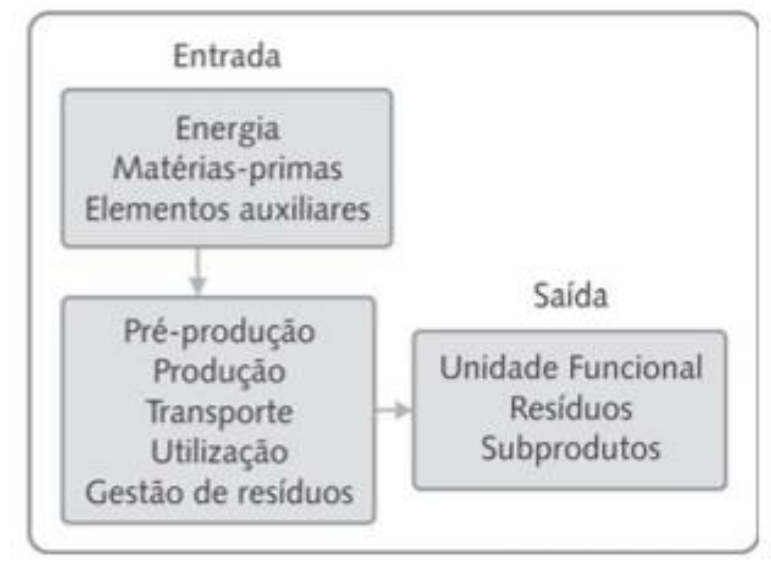

Figura 1 Representação esquemática da ACV Fonte: Soares, Souza e Pereira (2006, p.99)

Segundo Edwards e Bennett (2003) ao se projetar um edifício sustentável é necessário considerar seu desempenho geral e a escolha de produtos deve obedecer este conceito. Para o autor, quando esta questão é tratada nos estágios iniciais do projeto, é possível obter melhores resultados, além de conseguir obter um equilíbrio entre os aspectos técnicos e ambientais, pois considerar a ACV é muito importante para a obtenção de um bom resultado.

As legislações também estão cada vez mais exigentes em relação ao desenvolvimento sustentável. Para Gehin, Zwolinski e Brissaud (2007) para atender as constantes demandas da legislação europeia, principalmente para equipamentos eletrônicos, veículos desgastados e substâncias perigosas, a manufatura teve que desenvolver análises de ciclo de vida dos produtos, focando no fim de sua "vida".

A ACV é uma ferramenta importante, utilizada para examinar a vida útil do produto e disposição final, além de avaliar os impactos do processo industrial e extração de 
matéria prima (CATANIA; LA MANTIA, 2004). A figura 2 demonstra que o material pode estender seu ciclo de vida através da reciclagem, remanufatura e reutilização.

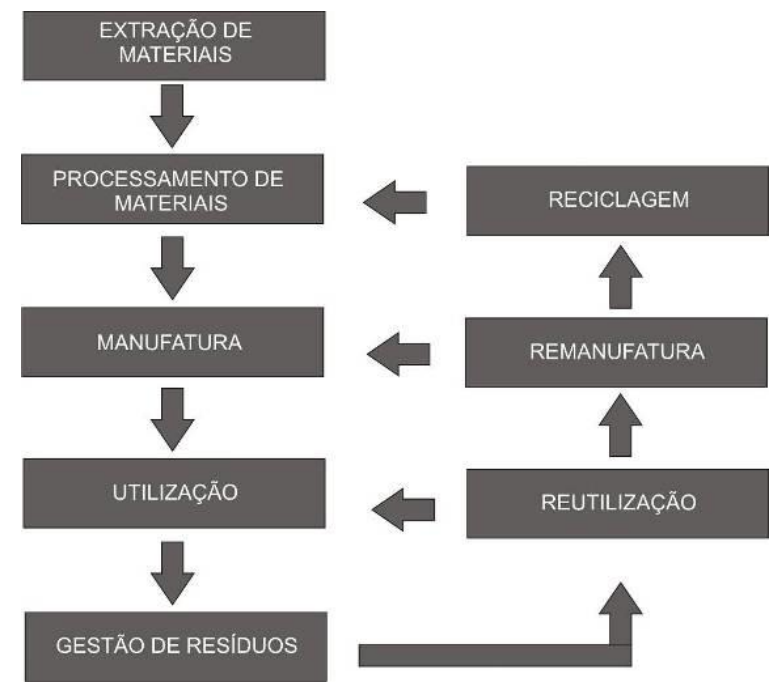

Figura 2 Esquema de ciclo de vida em que o material pode ser reaproveitado através da reciclagem, remanufatura e reutilização.

Fonte: Catania; La Mantia (2004, p.226)

Para Edwards e Bennett (2003) também é importante analisar como o material é produzido e como é utilizado. Isso abrange o conceito de Design for Adaptability (Projeto para Adaptação) e Design for Deconstruction (Projeto para a Desconstrução). Os autores afirmam que os materiais e componentes de um edifício sejam projetados para que se torne possível a reciclagem, é uma grande responsabilidade nos dias de hoje, portanto devem abranger o conceito de Design for Deconstruction.

Para Gehin, Zwolinski e Brissaud (2007) um dos pontos de partida do Design for Environment (Projeto para o Meio Ambiente), onde também inclui o Projeto para o Desmonte, é a análise do Ciclo de Vida para identificar e quantificar os impactos ambientais causados pelos produtos. No entanto, a maioria dos métodos que medem os impactos ambientais é analisada apenas por especialistas e os projetistas precisam de métodos mais simples e eficientes, para serem agregadas as suas tarefas do dia a 
dia. Gehin, Zwolinski e Brissaud (2007) afirmam que os projetistas exigirão ferramentas que:

- possam ser integradas ao seu trabalho diário

- permitam que analisem o impacto ambiental dos produtos e componentes

- indique potenciais de reutilização, remanufatura e reciclagem.

Para os autores seria importante utilizar uma ferramenta que possibilite ao projetista avaliar os impactos ambientais dos produtos durante todo o seu ciclo de vida enquanto ele é projetado e posteriormente, seria possível dar o potencial de 3Rs (reutilizar, remanufaturar e reciclar).

Desta maneira, é possível que novas tecnologias e maneiras de construir sejam desenvolvidas, com o objetivo de facilitar a desconstrução do edifício após sua vida útil, de maneira a aproveitar melhor seus materiais e componentes, com a intenção de reduzir a quantidade de entulho gerada e consequentemente, o impacto ambiental.

Assim quando a ACV é considerado na concepção do projeto, além do conceito de Projeto para o Desmonte, é possível obter ganhos ambientais e contribuir com o desenvolvimento da construção sustentável.

Na figura 3 está representada a análise de entradas e saídas que devem ser consideradas nos estudos dos materiais utilizados nas construções, isto é importante quando for realizar a ACV, pois inclui a quantidade de energia utilizada, água e extração de materiais. 


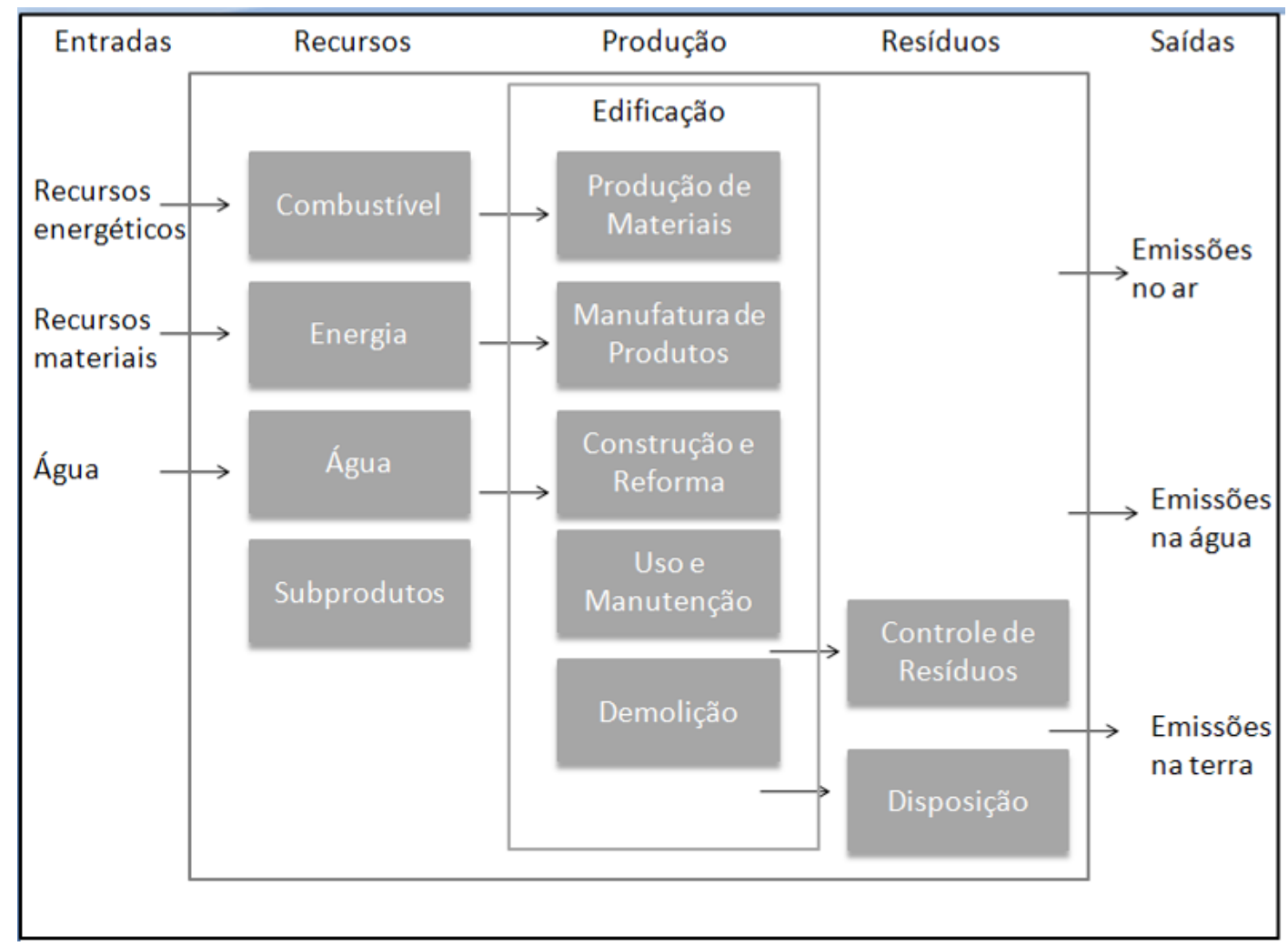

Figura 3 Aplicação de ACV nos produtos de construção civil Fonte: Edwards e Bennett (2003)

\subsection{ACV e Normas}

Para Gehin, Zwolinski e Brissaud (2007) algumas normas estão incentivando as companhias a reconsiderarem o seu processo de produção, como a ISO 9000 que incentiva o aprimoramento do processo de produção e a qualidade do produto e a ISO 14000 que melhorar a produção em relação ao meio ambiente. Segundo Edwards e Bennett (2003) o ISO 14040 e 14043 foram desenvolvidos para padronizar e definir as maneiras em que o ACV deve ser realizado. Posteriormente foi desenvolvida a 14.044 com referências mais específicas.

No Brasil, a norma ABNT NBR ISO 14044 dá diretrizes de como realizar uma Análise de Ciclo de Vida completa, além de estipular diretrizes para que se torne mais viável comparar os diversos resultados obtidos. Esta ISO é utilizada em vários países, assim 
torna-se possível comparar diversos materiais e resultados de maneira mais direcionada às necessidades dos usuários.

Na norma ABNT NBR ISO 14044 a avaliação do ciclo de vida (ACV) é uma técnica que contribui para a proteção ambiental, pois avalia os possíveis impactos causados pela fabricação e consumo dos produtos (e serviços). Segundo a norma, a ACV pode contribuir para identificar oportunidades, nas diversas etapas do ciclo, para melhorar seu desempenho ambiental. Além disso, auxilia o nível de informações para os tomadores de decisões. A norma especifica requisitos e prevê orientações para a análise do ACV como:

-definição e objetivo de escopo

-análise do inventário

-avaliação do impacto

-interpretação do ciclo

-comunicação e revisão crítica

-limitações

-relações entre diversas fases

-condições de uso e escolhas de valores e elementos

A norma especifica que para realizar uma ACV é necessário definir um objetivo e um escopo, uma unidade funcional, fronteiras do sistema, metodologias de ACV, tipos e fontes de dados. Assim se torna mais viável para que os produtos possam ser comparados.

Esta norma se originou de uma ISO, assim é utilizada em vários países. Dessa maneira, se busca uma tentativa de padronização para que os resultados possam ser comparados de maneiras mais diretas. A norma aborda detalhadamente como deve ser 
feito o estudo, e todas as etapas que o envolvem, assim os resultados serão mais confiáveis.

A norma aborda todas as fases do ciclo, desde a fase de extração de matérias-primas, incluindo o uso e a disposição final. No entanto, o estudo pode abordar apenas uma dessas fases, desde que seja justificado.

A ABNT NBR ISO 14044 também discute a questão do reuso e reciclagem no ciclo que é uma importante etapa, principalmente quando se busca reduzir os impactos ambientais do setor. A norma define como ciclo de duas maneiras: aberto e fechado. Sendo o ciclo fechado quando o material não sofre alterações de suas características iniciais ou é utilizado no mesmo setor. O ciclo aberto é considerando quando há alterações nas propriedades do material reciclado ou é utilizado em outra função, diferente da anterior.

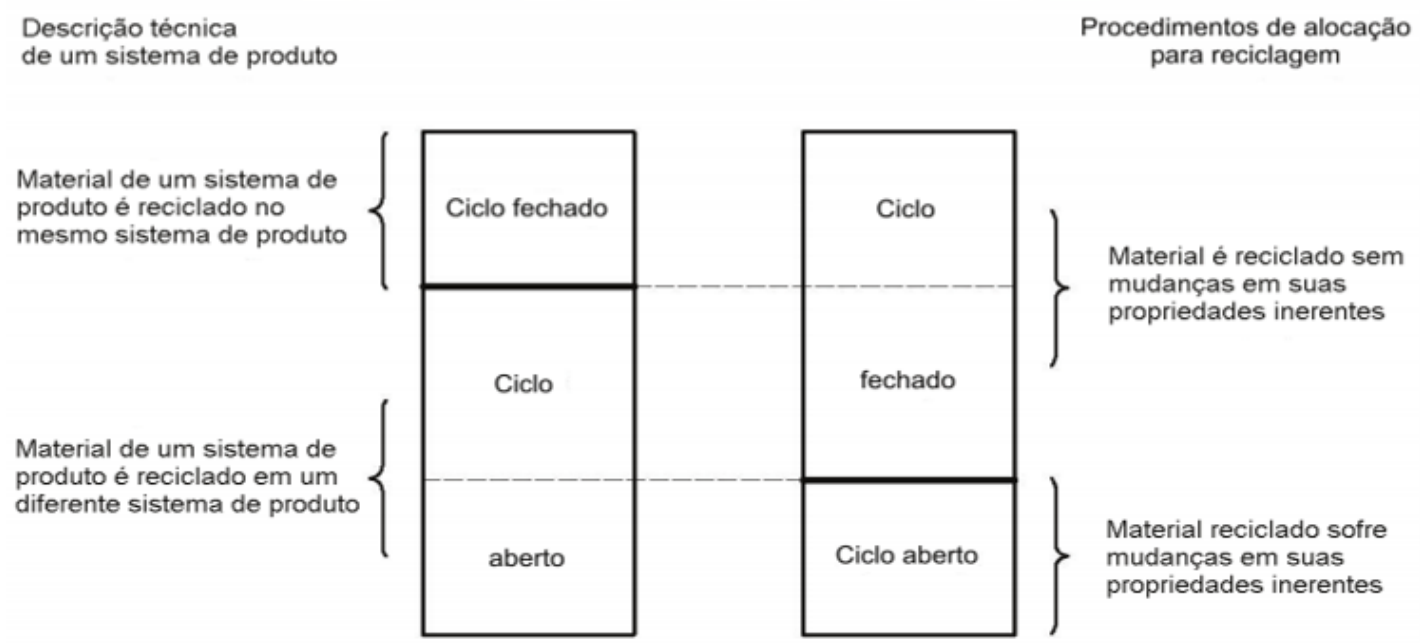

Figura 4 Distinção entre uma descrição técnica de um sistema de produto e procedimentos de alocação para reciclagem

Fonte: ABNT NBR ISO 14044

Também é analisada, no presente trabalho, a ABNT NBR 15575, pois ele prevê considerações na fase de projeto para a vida útil do edifício. O projeto está voltado para edifícios residenciais e trata de temas gerais do edifício como um todo e não 
apenas de seus materiais e sistemas. Nele constam exigências de durabilidade e manutenibilidade da construção que estão diretamente relacionadas com o projeto e o ciclo de vida dos materiais e da edificação.

Segundo a ABNT NBR 15575 a durabilidade do edifício e seu sistema estão associados ao custo global da obra e exigências dos usuários. A norma considera a vida útil do edifício o tempo entre o início da utilização do produto até quando atende mais as exigências pré-estabelecidas pelo usuário.

Deverá ser especificado a vida útil do projeto (VUP) para cada sistema que compõe o edifício. O prazo da vida útil do edifício começa a partir da emissão do Auto de Conclusão de Edificação (ou Habite-se). A tabela 1 apresenta a quantidade mínima de anos que cada subsistema da edificação deve atender. Considerar o ciclo de vida dos materiais no desenvolvimento do projeto é importante para que a obra possa obter esses resultados.

Tabela 1 Vida útil do projeto (VUP)

\begin{tabular}{cc}
\hline Sistema & VUP mínima (anos) \\
\hline Estrutura & $\geq 50$ \\
\hline Pisos internos & $\geq 13$ \\
\hline Vedação vertical externa & $\geq 40$ \\
\hline Vedação vertical interna & $>20$ \\
\hline Cobertura & $\geq 20$ \\
\hline Hidrossanitário & $\geq 20$ \\
\hline
\end{tabular}

Fonte: ABNT NBR 15575 (2013)

Assim, esta tabela ressalta a importância de considerar vida útil dos sistemas que compõem o edifício. Dessa maneira é possível observar que as construções, muitas vezes, são projetadas para resistir a algumas décadas, portanto se torna evidente a necessidade de considerar o fim do seu ciclo de vida e a destinação dos materiais utilizados. 
É importante ressaltar que esta preocupação está presente em diversos países. Considerar a vida útil dos materiais e da construção é uma necessidade de projeto. Soares, Souza e Pereira (2006) demonstram, na tabela 2, a vida útil média, estipulada pela comissão Europeia.

Tabela 2 Processos de construção civil e vida útil

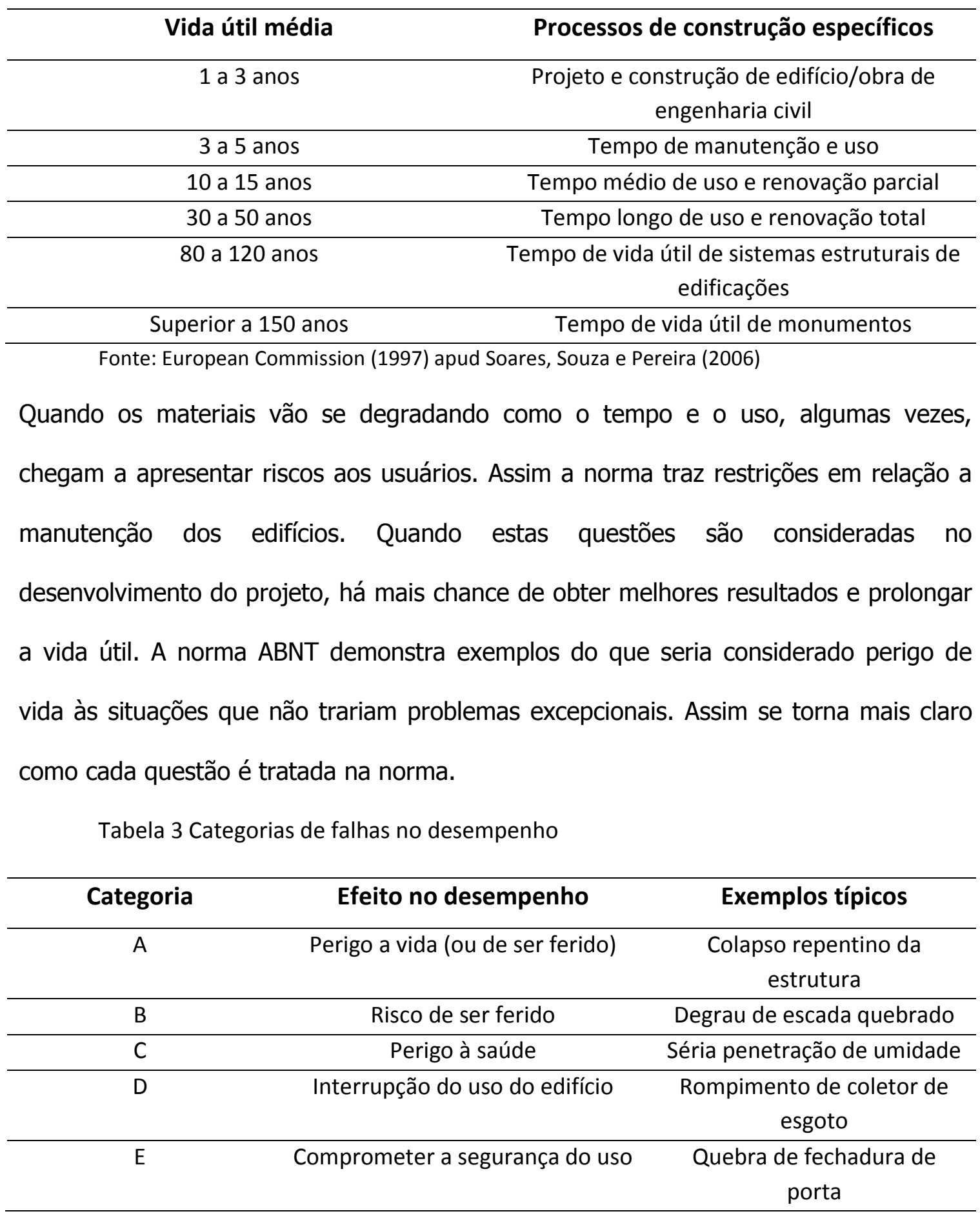




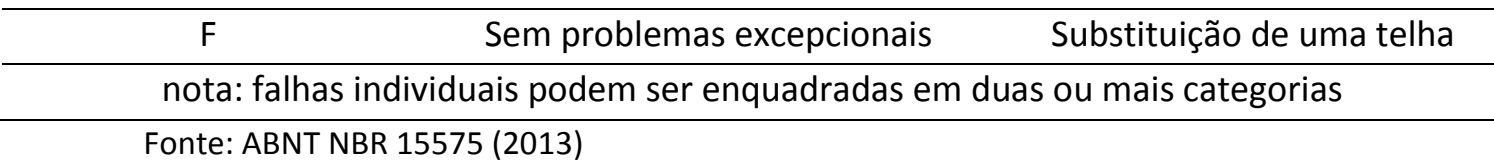

Nas edificações é possível substituir alguns componentes, ou fazer manutenções para que não fiquem totalmente danificados e ainda possam cumprir com as expectativas iniciais. Com a ACV é possível estipular quanto tempo o material utilizado estaria em bom estado e a aplicação do conceito do Projeto para o Desmonte, facilitaria a troca de materiais. A tabela 4 apresenta as 3 categorias: substituível, manutenível e nãomanutenível.

Tabela 4 Categoria de vida útil de projeto para partes do edifício

\begin{tabular}{|c|c|c|c|}
\hline Categoria & Descrição & Vida útil & Exemplos Típicos \\
\hline 1 & Substituível & $\begin{array}{c}\text { Vida útil mais curta que o edifício, sendo } \\
\text { sua substituição fácil e prevista na etapa de } \\
\text { projeto }\end{array}$ & $\begin{array}{c}\text { Muitos } \\
\text { revestimentos de } \\
\text { pisos, louças e } \\
\text { metais sanitários }\end{array}$ \\
\hline 2 & Manutenível & $\begin{array}{l}\text { São duráveis, mas necessitam de } \\
\text { manutenção peródica, e são passíveis de } \\
\text { substituição ao longo da vida útil do edifícil }\end{array}$ & $\begin{array}{l}\text { Revestimentos de } \\
\text { fachadas e janelas }\end{array}$ \\
\hline 3 & $\begin{array}{c}\text { Não- } \\
\text { manutenível }\end{array}$ & $\begin{array}{l}\text { Devem ter a mesma vida útil do edifício por } \\
\text { não possibilitarem manutenção }\end{array}$ & $\begin{array}{c}\text { Fundações e muitos } \\
\text { elementos } \\
\text { estruturais }\end{array}$ \\
\hline
\end{tabular}

Fonte: ABNT NBR 15575 (2013)

A tabela 5 apresenta o tempo de vida útil dos subsistemas exigido pela norma. Novamente, se estas questões fossem consideradas na fase de projeto, seria possível, trocar ou manter alguns dos subsistemas sem que danificassem outros, assim aumentaria a vida útil das construções com maior qualidade.

Tabela 5 Vida útil de projeto mínima e superior (VUP)

\begin{tabular}{ccc}
\hline Sistema & VUP (anos) & \\
& Mínimo & Superior \\
\hline Estrutura & $>40$ & $>75$ \\
\hline
\end{tabular}




\begin{tabular}{cll}
\hline Pisos internos & $>13$ & $>20$ \\
\hline Vedação vertical externa & $>40$ & $>60$ \\
\hline Vedação vertical interna & $>20$ & $>30$ \\
\hline Cobertura & $>20$ & $>30$ \\
\hline Hidrossanitário & $>20$ & $>30$ \\
\hline
\end{tabular}

Fonte: ABNT NBR 15575 (2013)

A ABNT NBR 15575 afirma que quando as construções consideram a durabilidade, manutenibilidade e impacto ambiental, estão contribuindo para o desenvolvimento sustentável. Esta questão ainda não está muito desenvolvida na norma, mas nota-se que já começa a ser discutida.

As normas discutidas estão relacionadas pelo fato de uma depender da outra. Para que sejam cumpridas as exigências da norma 15.575 é necessário considerar a ACV dos materiais, subsistemas e do próprio edifício, que devem seguir as diretrizes da norma ABNT ISO 14.044. Assim, está claro que cada vez mais o projeto deverá considerar questões ambientais, tornando o processo mais complexo.

A produção de documentos legais que conduzam a um comportamento ambientalmente mais positivo, ou seja, que desperte e obrigue a indústria da construção a um tratamento mais cuidadoso dos resíduos que produz, é de vital importância para a contribuição deste setor para o desenvolvimento sustentável para o qual todos devemos contribuir (COUTO; COUTO; TEIXEIRA, 2006).

\subsection{Resíduos, Reciclagem e Reutilização}

O setor da construção civil causa grande impacto ambiental, o que é um grave problema para o setor, no entanto a reciclagem e reutilização podem amenizar a situação. Para Rocha e Sattler (2009) a análise do processo de reciclagem e reutilização dos produtos, em busca de fechar o ciclo de produção, pode influenciar 
nas estratégias utilizadas e repensar sobre os materiais de construção e componentes da cadeia de produção.

Os Resíduos da Construção e Demolição (RCD) muitas vezes são depositados em lugares inapropriados, isso gera graves problemas ambientais que causam transtornos à população e até mesmo colocam sua saúde em risco, pois contribuem com o surgimento de vetores causadores de doenças, assim em 2002, entrou em vigor a resolução do CONAMA 307 (CARNEIRO; SIQUEIRA et al., 2006).

A resolução do CONAMA $307 / 02^{6}$ aborda o tema dos resíduos sólidos por meio de diretrizes, critérios e procedimentos a serem tomados por governo municipais e agente envolvidos com o manejo e destinação do RCD (TESSARO; SÁ et al., 2012).

A Resolução busca orientar a gestão de resíduos, portanto, para se obter bons resultados, além de Reduzir,Reutilizar e Reciclar, também é fundamental Repensar a maneira de desenvolver o projeto arquitetônico (MEIRA; MELLO, 2012). Repensar esta etapa é extremamente importante para amenizar o impacto ambiental da construção civil, pois é possível prever diversas soluções para minimizar a quantidade de resíduos.

Através dos avanços tecnológicos, a sociedade conquistou vários benefícios, no entanto, alguns problemas também foram gerados, com os danos ambientais, o consumo excessivo de matéria prima e enorme geração de resíduos causaram graves problemas no meio urbano (CARNEIRO, SIQUEIRA et al., 2006). Várias metrópoles brasileiras têm sérios problemas relacionados aos $\mathrm{RCD}$, pois grande parte é depositada em locais irregulares, como margens de rios e estradas, praças, terrenos baldios, entre

\footnotetext{
${ }^{6}$ Atualmente foram criadas outras resoluções baseadas na Resolução CONAMA 307/02, como a 348/04 que inclui o amianto na classe de resíduos perigosos, a 431/11 que inclui o gesso na classe B (resíduos recicláveis) e a 448/12 sobre resíduos.
} 
outros, desta maneira contribuem com a degradação da meio ambiente e da paisagem urbana, além da proliferação de vetores causadores de doenças, enchentes, inundações, entre outros (CARNEIRO, SIQUEIRA et al., 2006).

Para Tessaro, Sá et al. (2012) a construção civil é um dos setores que causa maior impacto ambiental, o grande volume de resíduos gerados é depositado, na maioria das vezes, em lugares irregulares, assim agravam o problema de saneamento das áreas urbanas. Os autores realizaram uma pesquisa no município de Pelotas-RS e constataram que são produzidos diariamente, em torno de $315 \mathrm{~m}^{3}$ de resíduos de construção e demolição (RCD), assim uma taxa de 1,23 kg/hab.ano. A densidade dos resíduos é de 1,28 ton $/ \mathrm{m}^{3}$, onde $88 \%$ dos RCD são oriundos da classe A e tem grande potencial de reutilização e reciclagem. Nestes dados não estão incluídos os depósitos de resíduos irregulares.

Na Europa, todo ano, o fim da vida útil dos edifícios gera entre 8 e 9 milhões de toneladas de resíduos que devem ser apropriadamente remanejados (SANTINI, HERRMANN et al., 2010). Estes dados demonstram a importância de buscar soluções para o setor.

Assim, a reciclagem é uma solução importante que precisa ser desenvolvida. Para Gehin, Zwolinski e Brissaud (2007), atualmente, reciclar é umas das soluções mais comuns, mas está longe de atender aos objetivos da sustentabilidade. No entanto, os autores acreditam que as estratégias de EoL (End Of Life - Fim da vida útil) aplicadas nas primeiras fases da concepção do produto é uma das melhores soluções que precisa ser aprimorada, o uso consciente das estratégias e EoL podem contribuir para os 3R: reuso, remanufatura e reciclagem. Assim o projeto pode contribuir com melhores resultados na reciclagem. 
Para Klohn e Ferreira (2009), o descarte é uma das etapas de grande importância, pois as questões projetuais da desmontagem de um produto permitem que seus componentes e materiais sejam descartados de maneira mais adequada, facilitando e possibilitando novos usos e reciclagem.

No setor da construção civil, a disposição final dos materiais também é discutida, pois a demolição é uma atividade que gera muito entulho, bem mais que construção e reforma, assim é necessário o desenvolvimento de técnicas e práticas que buscam reduzir isso e potencializam o reaproveitamento (CARNEIRO, SIQUIERA et al., 2006). Para Rocha e Sattler (2009) a maior parte de geração de resíduos é durante as fases de construção, reforma e demolição. Segundo Guy e Rocha (2005) é importante considerar todo o ciclo de vida do edifício, inclusive a reutilização e reciclagem, desde a fase de projeto, afinal as definições sobre os materiais e componentes pode contribuir para a recuperação ambiental e econômicas responsável após a vida útil do edifício.

A cadeia produtiva da construção civil já é grande recicladora, no entanto é possível aumentar a quantidade de materiais reciclados, devido à grande quantidade de material consumido, assim esta questão ainda deve ser mais bem explorada (JOHN, 2005).

Para Heriqson, Rocha e Sattler (2008) grande parte dos recursos naturais é consumido pela indústria da construção civil, que em sua demolição gera resíduos que agridem a natureza. Resíduos provenientes da implantação, manutenção e demolição podem conter substâncias nocivas ao meio ambiente que contaminas o solo, a água e o ar, como adesivos, tintas, óleos, baterias, biocidas incorporados em madeiras tratadas, sulfatos provenientes da dissolução de gesso, entre outros (DEGANI; CARDOSO, 2002). 
Assim, se torna imprescindível buscar maneira para reduzir o impacto ambiental, através do reuso e reciclagem dos produtos e componentes (HENRIQSON; ROCHA et al., 2008). Para os autores, as questões culturais e financeiras têm grande importância na viabilização da reutilização de materiais.

Portanto, entender a edificação como um conjunto de componentes e subsistemas, e suas relações, é fundamental para projetar considerando o seu futuro desmonte e reutilização (HENRIQSON, ROCHA et al., 2008). Os autores definem os seguintes termos:

“(a) Estratégias de reutilização: procedimentos que permitem re-inserir resíduos de diferentes formas no processo produtivo. Exemplos: reuso, reaproveitamento e reciclagem.

(b) Reuso: estratégia de reutilização na qual uma parte da edificação é retirada ou removida para desempenhar a mesma função prévia. Pode envolver o reparo ou manutenção da parte. Exemplo: vigas de madeira (material elaborado), usadas na estrutura de um edifício existente, sendo empregadas novamente como uma peça na estrutura de um novo edifício.

(c) Reaproveitamento: estratégia de reutilização em que determinada parte é removida para desempenhar uma função diferente. Pode envolver reparo, manutenção elou mudança de forma da parte. Exemplo: vigas de madeira da estrutura de um edifício sendo empregadas na produção de elementos de revestimento ou vedação de um novo edifício.

(d) Reciclagem: estratégia de reutilização em que determinada parte é extraída, transformada em material amorfo e empregada na elaboração de novos produtos ou partes. Exemplo: vigas de madeira sendo transformadas em serragem, para elaboração de chapas de madeira prensada."

Para Fabrício (2002) considerar os diversos aspectos do ciclo de vida do produto, além de avaliar os impactos que podem causar durante a extração de matérias-primas, fabricação, uso e disposição final do produto ao meio ambiente, é um grande desafio. 
Para Rocha e Sattler (2009) a reutilização de componentes dos edifícios e reciclagem parece ser um processo complicado, que requer interação entre diferentes fatores com a intenção de criar um ambiente favorável.

A reciclagem só será vantajosa se aumentar a sustentabilidade da sociedade, isto é, contribuir com o desenvolvimento ambiental, social e econômico (JOHN; ÂNGULO, 2003).

Projeto para reciclar, desmonte e meio ambiente ajudará os projetistas a melhorar a concepção do produto e considerar questões sobre as atuais necessidades ambientais como: desmontagem e reciclagem, além da financeira (GO; WAHAB et al., 2011).

Para John e Ângulo (2003) o desenvolvimento de tecnologia nesta área pode contribuir com a reciclagem que pode obter benefícios se o novo material entrar em escala comercial, reduzindo o custo do produto o tornando-o mais competitivo.

A recuperação de produtos irá certamente exigir a desmontagem antes dos materiais e componentes serem reutilizados, remanufaturados ou reciclados (GO; WAHAB et al., 2011). Quando o material é remanufaturado, causa menor impacto ambiental do que quando é reciclado, para isso é importante prever o desmonte correto para melhor reaproveitamento (LEE; CHO et al., 2010).

Para a recuperação do produto devem-se considerar diversas questões, como a eficácia da desmontagem, o total de tempo necessário, a seqüência do desmonte, seu custo, o valor dos produtos no final do ciclo de vida, entre outras (GO; WAHAB et al., 2011). Quando o projeto considera o final do ciclo de vida do produto, fica mais viável reaproveitar seus materiais e componentes (LEE; CHO et al., 2010). 
Assim, é importante considerar a vida útil e as maneiras de reciclar ou reutilizar os materiais e componentes dos edifícios, pois isto está diretamente ligado ao desenvolvimento sustentável, por contribuir com a redução da poluição causada pela construção civil e economizar matérias-primas. 


\section{PROJETO PARA O DESMONTE}

A fase da demolição é um ponto chave para adotar medidas mais sustentáveis e reduzir a grande quantidade de resíduos gerados pelo setor (ROCHA; SATTLER, 2009). Assim, este capítulo trata do conceito de Projeto para Desmonte ou Desconstrução (Design for Disassembly - DFD) que deve ser incorporado na fase do desenvolvimento do projeto, como uma ferramenta para aproveitar melhor os componentes e materiais utilizados nas edificações, principalmente após a vida útil do edifício.

Muitos desses materiais têm o ciclo de vida maior que dos próprios edifícios, portanto podem ser reaproveitados em outras construções, caso isto seja considerado desde o desenvolvimento do projeto, maiores são as chances de reaproveitá-los.

Este conceito é mais comum de ser aplicado em alguns setores industriais, como o automotivo e o eletrônico, mas é possível obter importantes informações com sua análise e aplicar no setor da construção civil. Assim, diversas referências utilizadas neste capítulo focam vários setores industriais e também o da construção civil.

Nas indústrias, o Projeto para Disassembly (DFD) é um método que pode ser aplicado durante desenvolvimento do projeto para melhorar a capacidade de reciclagem de todo o produto (Go, Wahab et al., 2011).

$\mathrm{Na}$ construção civil, as edificações também se tornam produtos. Muitos prédios são construídos com a idéia de que são permanentes, enquanto que na verdade, a sua espectativa de vida são apenas algumas décadas, sendo que alguns materiais podem ter a vida útil de séculos (Crowther, 1999). Assim, a construção civil também deve buscar soluções para os materiais utilizados nas edificações após a vida útil dos edifícios, para evitar desperdícios e reduzir o consumo de matérias-primas. 
O Projeto para Desconstrução é uma das variáveis do Projeto para "X", que envolve diversos conceitos que podem ser aplicados no desenvolvimento do projeto, assim, será abordado este tema inicialmente de maneira breve, para melhor entendimento do conceito a ser estudado.

\subsection{Projeto para "X" - Base do conceito do Projeto para o Desmonte}

Na década de 70, foram desenvolvidas ferramentas chamadas de Design for $X$, para atender a evolução do desenvolvimento do projeto de produtos (ROMEIRO FILHO, 2010). Segundo o autor a letra " $X$ " pode ser trocada por outras iniciais, que signifique manufatura, modularidade, desmontagem, custo, meio ambiente, reciclagem, entre outras.

Este conceito também é mais utilizado nas indústrias automotivas e eletrônicas. No entanto é interessante analisar a relação dos produtos gerados por esses setores com o edifício, como sendo um produto da construção civil. Pois em todas essas áreas é importante considerar o impacto ambiental do produto e a busca para reduzir o consumo de matérias-primas e geração de resíduos.

Para Romeiro Filho (2010), cada vez mais, os produtos devem atender as necessidades mais específicas, pois os consumidores e as legislações estão mais exigentes. O autor afirma que além dos projetos precisarem de várias ferramentas para que possam atender grande parte dos requisitos, também é importante a integração dos projetos.

Assim se torna essencial a incorporação de ferramentas, como o Design for " $X$ ". Os autores Kuo, Huang e Zhang (2001) listam algumas variáveis deste conceito: 
- Projeto para a Montagem (Design for Assembly - DFA) - Se baseia no conceito de obter o menor custo de montagem através de definições tomadas na fase projetual. Durante a montagem de um produto há dois fatores determinantes que são os números de partes a serem montadas e o grau de dificuldade do manuseio, inserção e fixação. Uma das características deste conceito é usar peças modulares, que também contribui para a desmontagem.

- Projeto para a Manufatura (Design for Manufacture - DFM) - Este conceito busca atender as necessidades das peças e analisar vários usos. Neste processo são consideradas questões como seleção de materiais, processos, desenho modular, componentes padrões, partes multiusos, fixadores separados e minimização da direção de montagem.

- Projeto para a Desmontagem e Reciclagem (Design for Disassembly and Design for Recyclability - DFD, DFR) - Busca-se considerar o processo de desenvolvimento do produto para que o material seja desmontado com mais facilidade e possibilite melhores resultados de reciclagem. Há consumidores que buscam produtos "verdes", além disso, alguns governos estão tomados iniciativas para incentivar a fabricação e venda desses produtos.

- Projeto para o Meio Ambiente (Design for Environment - DFE) - Este conceito engloba várias questões: gestão de riscos ambientais, saúde, segurança ocupacional e do produto, prevenção de poluição, ecologia, conservação de recursos, prevenção de acidentes e gestão de resíduos (MCC,1993 apud KUO; HUANG; ZHANG, 2001).

- Projeto para o Ciclo de Vida (Design for life-cycle - DFLC) - Inclui fases de projeto, pesquisa de mercado, processo de manufatura, qualificação, confiabilidade, atendimento ao cliente, manutenção e suporte. A análise do ciclo de vida inclui diversos fatores: materiais, produtos, serviços, processos e tecnologias, ao longo de sua vida.

- Projeto para a Qualidade (Design for Quality - DFQ) - Este projeto deve ir de encontro às necessidades do cliente, além de melhorar o desempenho do produto.

- Projeto para a Manutenção (Design for Maintainability - DFM) - Este conceito busca garantir a possibilidade de manutenção do produto ao longo de sua vida a um preço acessível.

- Projeto para Confiabilidade (Design for Reliability - DFR) - é necessário se basear em quatro fatores: probabilidade, função específica, ambiente e tempo. Os autores citam a definição de Advisory Group of Eletronic Equipment (1957) "a confiabilidade é definida 
pelo desempenho do produto sem falhas em uma função específica, em determinadas condições, durante um determinado período de tempo."

Kuo, Huang e Zhang (2001) concluem que DFD, DFR e DFLC colaboram com que o projetista planeje com antecedência o processo de desmonte e descarte do produto, DFA e DFM contribuem pra que o produto seja produzido com mais facilidade e com menor tempo. Para os autores qualidade, manutenção e confiabilidade podem ser asseguradas através do projeto e controle do processo de concepção ao invés de testes caros, diagnósticos e retrabalho.

Para Gehin, Zwolinski e Brissaud (2008) umas das variáveis do DFX é o Design for Environment que envolve diversos conceitos como Design for Material (Projeto para o Material), Disassembly (Desmonte), Recycling (Reciclagem) e até mesmo repensar o Design for Manufacture (Projeto para Manufatura).

Romeiro Filho (2010) cita algumas ferramentas do DFX, que buscam aperfeiçoar o processo de produção do produto em diversas fases do projeto, e complementam os autores anteriores:

- Projeto para Manufatura e Montagem - Design for Manufacture and Assembly (DFMA): criado ainda na década de 1970, prevê a busca da simplicidade na montagem, redução do número e padronização dos componentes, redução de custos com remontagem, maior confiabilidade, menores custos.

- Projeto para Conformidade - Design for Compliance (DFC): projetar levando em consideração as conformidades regulares exigidas para fabricação e uso do produto.

- Projeto para qualidade - Design for Quality (DFQ): projetar de acordo com as exigências do cliente; projetar um produto robusto que ultrapasse as expectativas do cliente.

- Projeto para Serviço - Design for Service (DFS): projetar para facilitar a instalação inicial, bem como o reparo e a modificação dos produtos no campo ou nos centros de serviços. 
- Projeto para Logística do material e Aplicação de Componente - Design for Material Logistics and Component Applicability (DFMC): centraliza-se na fábrica, no movimento do material, nas considerações de gerenciamento e nas aplicações correspondentes aos componentes e aos materiais.

- Projeto para Manutenção - Design for Maintainability (DFM): projetar para "fácil" manutenção, assegurando que o produto possa ser mantido em todo o seu ciclo de vida útil, com despesas razoáveis, sem qualquer dificuldade e, com isso, permitir o prolongamento de utilização do produto.

- Projeto para Teste - Design for Test (DFT): projetar para facilitar teste de fábrica e de campo em todos os níveis de complexidade do sistema: equipamentos, placas de circuitos, etc.

- Projeto para Meio Ambiente - Design for Environment (DFE): projetar considerando os aspectos ambientais em todo o ciclo de vida do produto. Busca o projeto de produtos que leva à redução de resíduos, seja durante os processos de produção, seja durante a vida útil do produto.

- Projeto para Desmontagem - Design for Disassembly (DFD): origina-se da necessidade de gerenciamento de resíduos e componentes resultantes da montagem e desmontagem do produto. Objetiva a aproveitar os recursos, matérias-primas e energia, minimização de efluentes tóxicos e eventual disposição de resíduos oriundos dos processos produtivos.

Para o autor o DFX é utilizado em diversos setores, como na engenharia de produção, mecânica, aeroespacial, automotiva, eletrônica, elétrica, etc. O conceito tem apresentado diversas vantagens nas indústrias, principalmente nas automotivas, como:

- Introdução de diversas ferramentas em diferentes etapas do processo de produção, manutenção, desmontagem e reciclagem;

- Surgimento de ferramentas com o objetivo de aumentar a competitividade, referente a custos, qualidade, flexibilidade, meio ambiente, entre outros;

- Surgimento de mais ferramentas, e melhores, mesmo que ainda precisem de mais pesquisas e demonstrações;

- Os projetistas estão utilizando mais o DFX, mas ainda há muito para crescer; 
- Desenvolvimento de ferramentas que buscam mais integração entre os projetos, análise de mercado, etc.

Assim, a seguir serão analisadas características do Projeto para o Desmonte nas indústrias em geral, antes de abordar o setor da construção civil.

\subsection{Projeto para Desmonte em diversos ramos industriais}

O projeto para o Desmonte é uma das variáveis do Projeto para o $\mathrm{X}$, analisado no item anterior. Para Manzini e Vezzoli (2008) "Design for Disassembly (DFD) quer dizer conceber e projetar produtos facilitando a sua desmontagem. Significa, portanto, tornar ágeis e econômicos o desmembramento das partes componentes e a separação dos materiais."

É importante analisar a aplicação desta ferramenta nos setores industriais para entender como é utilizada, quais os obstáculos e os benefícios obtidos. O DFD já é uma ideia explorada nas indústrias onde o conceito de reutilizar, reciclar e remanufaturar são exigidos (GUY; ROCHA, 2005).

Projeto para Disassembly (DFD) é um método que pode ser aplicado durante desenvolvimento do projeto para melhorar a capacidade de reciclagem de todo 0 produto (GO; WAHAB et al., 2011).

Romeiro Filho (2010) define a desmontagem "como método sistemático para a separação de peças, componentes e subconjuntos de um produto". Assim facilita a recuperação do produto, através da reciclagem e reprodução.

Para Go et al. (2011) a desmontagem é importante para recuperar componentes e materiais, pois quando o projetista considera este conceito deve analisar as 
possibilidades de desmonte do produto e de suas partes. O autor cita o exemplo da manufatura de automóveis e componentes que devem considerar as possibilidades de desmonte e reciclagem, desde o início do projeto, assim contribui para aumentar as possibilidades de reuso e remanufatura de maneira mais sustentável. O DFD busca tornar mais fácil e veloz a desmontagem considerando as juntas e estrutura dos veículos (SANTINI; HERRMANN et al., 2010).

Para Klohn e Ferreira (2009) o design para desmontagem é uma importante ferramenta para reduzir os danos ambientais gerados pela fabricação de produtos, pois facilita a manutenção, reutilização e reparação, além de contribuir o aumento da vida útil. Para os autores, o projeto também facilita a separação dos materiais, assim tornando-os mais fáceis de serem reutilizados, sem precisarem passar por processamentos e reciclagem, ou serem descartados na natureza.

Para Manzini e Vezzoli (2008) o conceito do desmonte deveria ser mais utilizado por diversos motivos, como expandir a vida útil dos produtos, seus materiais, além da possibilidade de prevenir que se tornem tóxicos e danosos.

Para Romeiro Filho (2010) "O projeto para desmontagem (Design for Disassembly) é uma das estratégias disponíveis para a concepção de produtos cuja reciclagem seja economicamente justificada". Além disso, para o autor, deve facilitar o desmonte do produto e a reutilização dos materiais e componentes, pois alguns produtos, onde os encaixes são facilitados, por exemplo, é mais fácil reutilizar os materiais e componentes, além de tornar mais fácil a manutenção.

Segundo o autor, o projeto pode contribuir de diversas maneiras, como permitir que o produto seja desmontado sem força, através de mecanismos simples, sem utilização 
de ferramentas, assim é importante deixar claro os pontos de identificação de desmontagem, a estrutura deve ser simples e não utilizar materiais tóxicos.

O projetista pode contribuir para o aumento do número de alternativas, soluções de problemas técnicos, estimular a imaginação e orientar, sem impor suas condições aos seus clientes, além de propor oportunidades para se tornar mais sustentável (MANZINI; VEZZOLI, 2008).

O processo de desmonte deve ser o mais automatizado possível para garantir que a reciclagem seja economicamente competitiva e atenda a legislação que está cada vez mais rigorosa (GO; WAHAB et al., 2011). Segundo estes autores há várias tentativas nas indústrias para estudar estas questões no contexto de produtos específicos desde a década de 1990.

Integrar conceitos do final do ciclo de vida ao início do desenvolvimento do projeto é um importante aspecto que deve ser levado em consideração quando de debate questões sobre o fim da vida útil do produto, possibilidades de reciclagem e projeto para desmonte (GO; WAHAB et al., 2011). A recuperação de produtos irá certamente exigir a desmontagem antes dos materiais e componentes a serem reutilizados, remanufaturados ou reciclados. Para os autores, o tempo também é um ator muito importante no conceito do Projeto para o Desmonte e está diretamente ligado ao custo do processo, pois é necessário determinar o estágio ideal de desmontagem, quando todos os componentes economicamente valiosos são recuperados.

Segundo Go Wahab et al. (2011), para a recuperação do produto deve-se considerar diversas questões, como a eficácia da desmontagem, o total de tempo necessário, a seqüência do desmonte, seu custo, o valor dos produtos no final do ciclo de vida, entre 
outras. Além disso, para os autores, o estudo para desmontagem deve considerar o estágio ideal de desmontagem, a fim de melhorar a recuperação dos produtos.

Porém, um dos grandes obstáculos na desmontagem para o reaproveitamento é o alto custo do processo. O projetista pode contribuir desenvolvendo produtos que facilitem a separação de módulos, peças e componentes, para que o custo de desmontar também seja economicamente viável (ROMEIRO FILHO, 2010).

Na tabela abaixo estão as principais características gerais a serem consideradas em relação ao Projeto para o Desmonte e os principais autores que as citam.

Tabela 6 Conceitos que contribuem para o Projeto para o Desmonte, no contexto industrial em geral, de diversos autores.

\begin{tabular}{|c|c|}
\hline Orientações para Projeto para o Desmonte & Autores \\
\hline Tornar o processo de desmontagem mais ágil & Manzini e Vezzoli (2008) \\
\hline $\begin{array}{l}\text { Considerar maneiras simples de desmontar } \\
\text { (sem força e ferramentas) }\end{array}$ & Romeiro Filho (2010) \\
\hline $\begin{array}{l}\text { Aumentar a capacidade de reciclagem e } \\
\text { reutilização }\end{array}$ & $\begin{array}{l}\text { Manzini e Vezzoli (2008); Guy e Rocha (2005); } \\
\text { Go, Wahab et al (2011), Romeiro Filho (2010); } \\
\text { Klon e Ferreira (2009) }\end{array}$ \\
\hline $\begin{array}{c}\text { Projetar sistemas estruturais que facilitem a } \\
\text { desmontagem }\end{array}$ & Santini e Herman (2010) \\
\hline Utilizar estrutura simples & Romeiro Filho (2010) \\
\hline Utilizar juntas que facilitem o processo & Santini e Herman (2010) \\
\hline $\begin{array}{c}\text { Considerar os encaixes que facilitam a } \\
\text { desmontagem }\end{array}$ & Romeiro Filho (2010) \\
\hline Expandir a vida útil dos materiais & Manzini e Vezzoli (2008) \\
\hline $\begin{array}{l}\text { Prevenir que os materiais se tornem tóxicos } \\
\text { ou danosos }\end{array}$ & Manzini e Vezzoli (2008) \\
\hline Não utilizar materiais tóxicos & Romeiro Filho (2010) \\
\hline $\begin{array}{c}\text { Deixar claro e identificar os pontos de } \\
\text { desencaixe }\end{array}$ & Romeiro Filho (2010) \\
\hline $\begin{array}{l}\text { Considerar a relação entre o custo e tempo } \\
\text { da desmontagem }\end{array}$ & Go, Wahab et al (2011) \\
\hline Considerar o custo do desmonte & Romeiro Filho (2010); Go, Wahab et al (2011) \\
\hline Tornar a reciclagem economicamente viável & Romeiro Filho (2010); Go, Wahab et al (2011) \\
\hline $\begin{array}{c}\text { Tornar o processo de desmontagem mais } \\
\text { econômico }\end{array}$ & Manzini e Vezzoli (2008) \\
\hline Identificar o tempo ideal da desmontagem & Go, Wahab et al (2011) \\
\hline
\end{tabular}




\begin{tabular}{cc}
\hline Prever a sequência de desmonte & Go, Wahab et al (2011) \\
\hline Considerar a eficácia do processo & Go, Wahab et al (2011) \\
\hline $\begin{array}{c}\text { Considerar o valor do produto no fim do ciclo } \\
\text { de vida }\end{array}$ & Go, Wahab et al (2011 \\
\hline $\begin{array}{c}\text { Os projetistas podem contribuir orientando o } \\
\text { cliente e fornecendo opções }\end{array}$ & Manzini e Vezzoli (2008) \\
\hline
\end{tabular}

Quando o conceito é aplicado é possível obter diversos benefícios. Romeiro Filho (2010) cita diversas vantagens na implantação desta ferramenta como:

- Manusear facilmente as peças, assim facilitando a separação dos materiais;

- Redução do trabalho para recuperar peças e reciclar os materiais;

- Diminuição de variáveis do produto;

- Permite desmontagem simples e rápida, além de uniformizar o produto.

Assim é possível perceber as vantagens da aplicação do Projeto para o Desmonte nas indústrias em geral, na Construção Civil também é possível obter muito ganhos, como será mostrado no próximo item.

\subsection{Projeto para Desmonte na Construção Civil}

As indústrias automobilísticas e eletrônicas podem fornecer algumas orientações para a construção civil, como princípios e práticas para a desconstrução (AMOÊDA, 2009). No entanto, algumas características da indústria da construção civil fazem com que seja diferente de outros setores industriais, como a grande rotatividade de mão de obra, a produção realizada em diferentes locais, diversidade de tipologias e grande quantidade de subempreiteiras utilizadas (BARKOKÉBAS JÚNIOR; VÉRAS et al., 2008).

Neste subitem será discutido o conceito aplicado diretamente na construção civil. Assim será apresentada uma revisão bibliográfica voltada para o setor. Os autores estudados utilizam as expressões Projeto para o Desmonte ou Projeto para 
Desconstrução. Neste trabalho será mais utilizada a expressão Projeto para o Desmonte, pois se aproxima mais do conceito de projetar para um futuro desmonte de peças, materiais e componentes, o que seria ideal. Alguns autores se referem ao Projeto para Desconstrução, quando a obra foi construída sem a intenção do desmonte ou desconstrução e depois é necessário buscar soluções para desconstruí-la. Além disso, quando se fala sobre Desconstrução em arquitetura, muitas vezes se remete ao movimento "desconstrutivista" que não tem nenhuma relação com este trabalho. Inicialmente serão apresentadas algumas definições de Design for Disassembly.

Para Guy e Rocha (2005) o Projeto para o Desmonte ou Desconstrução, no ambiente construído, é uma nova abordagem de design que incorpora os materiais do edifício e o seu ciclo de vida na fase de projeto. Para os autores, projetar um edifício para ser desmontado possui metas econômicas e de responsabilidade ambiental, pois considera a recuperação dos materiais, componentes e sistemas, após a vida útil da edificação, além de facilitar reparações, renovações e substituições, e evitar a demolição.

Thormark (2001) define o termo da seguinte maneira: Projeto para a desmontagem é um projeto voltado para a construção que busca a maneira mais fácil possível de desmontar, ou seja, um design que facilita a reutilização futura ou reciclagem dos materiais e componentes utilizados.

Segundo Couto, Couto e Teixeira (2006), a desconstrução ou demolição seletiva de um edifício facilita a reutilização de materiais, reciclagem, inovação tecnológica, sustentabilidade, além de contribuir com o mercado de materiais utilizados, que gera benefícios ao meio ambiente. Além disso, para os autores, isto valoriza os materiais e componentes, que seriam classificados como resíduos, sem valor e depositados em aterros. 
Razaz (2010) afirma que o Design para desconstrução refere-se ao projeto de um edifício com a intenção de tornar o fim da sua vida útil mais eficiente.

O projeto é o ponto de partida do edifício, assim se espera que os arquitetos responsáveis por esta etapa, tomem decisões com o intuito de minimizar danos ambientais (DEGANI; CARDOSO, 2002).

Além disso, para Klohn e Ferreira (2009) o projetista é capaz de desenvolver projetos considerando diversos aspectos como a vida útil, custo, considerar questões ecológicas em todo o seu ciclo.

O Projeto para a Desconstrução pode reduzir significadamente, os resíduos da construção e demolição, que constituem um grande porcentual de resíduos sólidos em todo o mundo (GUY; ROCHA, 2005).

Para Crowther (2005) o desmonte das construções para facilitar a reutilização de materiais e componentes não é muito comum atualmente. Para o autor existem três pontos centrais na aplicação do DFD: projetar de maneira sustentável, considerar as diferentes camadas do edifício e uma hierarquia de diferentes tipos de materiais e componentes a serem reutilizados.

Entender que o edifício é uma composição de componentes e materiais, além de sua relação de diferentes partes, ajuda a encontrar melhores soluções para reutilizar essas partes (HERIQSON; ROCHA; SATTLER, 2008). Os autores têm algumas definições de camadas:

- Peças: produtos que compõem o edifício

- Materiais: sem função específica (cimento, areia, pintura, placas, perfil de aço)

- Componentes: produtos com funções definidas (janelas, fechamentos) 
- Elementos: materiais com componentes que é uma parte da construção (paredes, portas)

- Subsistema: materiais com componentes e elementos que têm uma função (módulos sanitários, fachada)

- Sistema: subsistemas que têm uma solução completa para o edifício (telhado, estrutura)

Considerar estas diferentes camadas durante o desenvolvimento do projeto contribui para obter melhores resultados na desmontagem, sem comprometer as outras camadas. Normalmente os edifícios são projetados pensando na sua construção, uso e disposição dos resíduos. No entanto os edifícios podem viver muito mais, pode ser alterado ao longo de sua vida útil, muitas vezes a estrutura continua a mesma e as camadas internas são alteradas (CROWTHER, 2005).

Adaptar os princípios do Projeto para o Desmonte para contexto da indústria da construção apresenta sérios desafios devido às diferenças entre produção industrial e construção civil. Para Brewer e Mooney (2008) alguns desses desafios são:

- A dificuldade de rotulagem de componentes individuais e produtos com dados significativos de reciclagem;

- Os altos níveis de utilização dos materiais genéricos e compostos utilizados na construção;

- A disparidade entre o projetado e a realidade construída, onde substituições de materiais e produtos especificados por não autorizados;

- A falta de coordenação da reutilização/reciclagem de processo para um edifício particular;

- Cuidados com os edifícios em relação à toxicidade dos produtos, pois o uso de materiais e revestimentos que atualmente são considerados seguro e aceitável, mas que podem mais tarde vir a ser considerada como perigosos para a saúde ou a meio ambiente. 
Mesmo assim, com a desconstrução é possível obter melhores resultados na reutilização de materiais quando comparada a demolição. Quando for considerar o desmonte é fundamental considerar a maneira com que o edifício foi construído, pois a relação entre os diferentes componentes e materiais, as conexões entre diferentes camadas, influenciam no desmonte e reuso (HERIQSON; ROCHA; SATTLER, 2008).

As conexões dos materiais e componentes é uma questão muito importante para o Projeto para o Desmonte, pois podem contribuir ou atrapalhar o processo. Muitas vezes danificam os materiais e os tornam inutilizáveis. Durmisevic e Noort (2003) apresentam algumas conexões na ordem das que mais contribuem para as que mais danificam os materiais.

- encaixadas

- conectores com acessórios externos

- conectores com acessórios integrados

- conectores integrados

- peças com dispositivos para conexões integradas

- ligações químicas

\section{๘-घ}
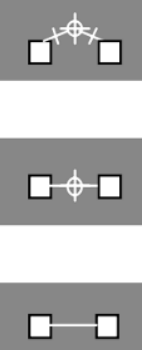

\section{$\square+\square$}

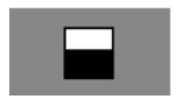

Figura 5 Diversos tipos de ligações (DURMISEVIC, NOORT; 2003)

Além disso, algumas melhorias para facilitar o processo de desmontagem e obter melhores resultados como: projetar considerando o desmonte; utilizar peças e materiais resistentes; buscar realizar conexões com parafusos e encaixes; evitar ligações químicas; propor ligações independentes entre as partes; utilizar peças de fácil 
manuseio, transporte e armazenamento; facilitar o acesso em todas as partes da edificação e reutilizar materiais nas novas construções. (Henriqson; Rocha; Sattler, 2008).

Crowther (1999) também sugere algumas maneiras para facilitar a desmontagem:

- Uso de conexões mecânicas no lugar de químicas

- Separar estrutura e compartimentos

- Dimensionar os componentes para facilitar o manuseio e a desmontagem

- Compatibilizar os sistemas

- Identificação os materiais e componentes

- Utilizar áreas comuns do edifício e fazer com que o usuário participe

- Permitir acesso para a desmontagem

- Permitir que os componentes fossem desmontados simultaneamente

Yuba (2005) também cita alguns critérios a serem analisado durante o desenvolvimento do projeto, para que contribuam com a desmontagem do edifício. A autora cita alguns exemplos como:

- Adotar sistemas aberto

- Facilitar as ligações das peças e montagens dos componentes

- Adotar dimensões padronizadas

Heriqson, Rocha e Sattler (2008) também têm algumas sugestões de como melhorar a desmontagem das construções:

- Usar materiais e componentes resistentes e duráveis

- Usar parafusos e conexões que não danifiquem os elementos 
- Evitar conexões químicas

- Projetar camadas independentes

- Facilitar o acesso a todas as partes do edifício

- Reutilizar materiais e componentes para estimular a prática

Para Crowther (2005) também é muito importante considerar o porquê, o quê, onde e quando demolir, para obter melhores resultados. Essas questões podem auxiliar para obter melhores resultados. Pensar em qual a intenção do desmonte (economia de tempo, dinheiro, questões sustentáveis), o que vale a pena ser desmontado, que partes serão desmontadas e o momento que isto será realizado.

Guy e Shell (2002) também citam algumas questões que devem ser consideradas no Projeto para o Desmonte:

- Quais partes do edifício sustentam outras partes?

- Quais as partes do edifício se sustentam, são independentes?

- Onde são entradas e saídas de serviços especializados (telecomunicações, eletricidade, gás, água, esgoto, fornecimento e ar de exaustão) ocorrem e como são estes fluxo mecanismos construídos?

- Quais as partes do edifício estão mais sujeitas às variações do clima?

- Quais são as partes do edifício estão mais sujeitas ao desgaste do uso humano e mudanças de preferências estéticas?

- Quais as partes do edifício são mais sujeitas a alterações funcionais, econômicas, expectativa de vida e requisitos tecnológicos?

- Quais as partes do edifício são compostas de componentes e sub-componentes baseados em um complexo sistema funcional e quais servem apenas uma função e, conseqüentemente, são compostas de materiais relativamente homogêneos? 
- Quais as partes de um edifício representam perigos maiores de trabalhadores na desmontagem?

- Quais são os tamanhos dos principais elementos e componentes de um edifício?

- Quais são os elementos mais caros de um edifício, que tem o maior reutilização e valor de reciclagem e que tem o maior impacto na eficiência do ciclo de vida?

Estas questões ajudam o observar o que deve ser considerado e priorizado no Projeto para o Desmonte. É possível obter melhores resultados quando se questiona o que se pretende com o projeto e como pode contribuir.

Considerar os objetivos do projeto também é fundamental. Para Guy e Shell (2002) os objetivos do Projeto para o Desmonte devem ser:

- A remoção rápida do edifício do local

- Tornam o ambiente mais saudável e seguro para os trabalhadores

- Fácil acesso de componentes e materiais para prevenção de danos processo de desconstrução

- Reduzir os custos de ferramentas e equipamentos, o que inclui reduzir a variedade de ferramentas e utilização de operadores especializados

- Eliminar os resíduos de produtos no processo

- Recuperação de materiais com grande utilidade para a reutilização e reciclagem, contribui para obter maior retorno sobre o investimento no processo de desconstrução

- Não utilizar materiais tóxicos o que impacta em reutilização ou eliminação responsável sem limitar as oportunidades de reuso e reciclagem

- Aumentar a longevidade de um edifício, pois facilita novas adaptações. 
Quando várias dessas questões são consideradas no desenvolvimento do projeto, é possível obter diversos ganho. Para Crowther (1999), o conceito DFD apresenta diversas vantagens, como:

- Redução do consumo de recursos naturais

- Redução da perda de espécies e habitats

- Redução na geração de resíduos e poluição

- Melhorar a saúde humana e as condições sociais

Outras vantagens, apresentada por Guy e Rocha (2005), é que o edifício projetado para o desmonte também é mais fácil de montar, assim pode diminuir o tempo e a quantidade de mão de obra. Além disso, os autores afirmam que o DFD defende a independência de partes e sistemas o que também facilita a manutenção.

No entanto, há barreiras técnicas para o sucesso da recuperação dos materiais. Projetar para futura reutilização ou reciclagem tem grandes ganhos ambientais, mas também pode ter algumas consequências não tão boas, como a energia utilizada na reciclagem e alguns materiais tóxicos que são utilizados para aumentar a durabilidade, podem comprometê-los (CROWTHER, 2005). Assim é importante considerar o ciclo de vida completo do edifício, seus componente e materiais para obter bons resultados.

Considerar os materiais, componente e sistemas estruturais que serão utilizados é fundamental. Suas características podem facilitar ou dificultar o processo. É muito importante analisar o sistema empregado para que se obtenha um resultado satisfatório na desmontagem e contribua para um processo mais rápido, econômico e eficiente. Os autores Webster e Costello (2005) citam algumas características de diferentes sistemas construtivos. 
Tabela 7 Características de desmonte de diversos sistemas estruturais

\begin{tabular}{|c|c|}
\hline Sistemas construtivos & Características \\
\hline Estrutura em Madeira & $\begin{array}{l}\text { Grande potencial de reutilização } \\
\text { Exige cuidados na desmontagem para não danificar as peças } \\
\text { Necessidade de extrair pregos } \\
\text { Instalações de sistemas elétricos e hidráulicos podem danificar as } \\
\text { peças para facilitar a passagem de dutos e condutores. } \\
\text { Decisões tomadas em projeto para a desmontagem podem } \\
\text { contribuir como priorizar peças inteiras e conectores no lugar de } \\
\text { pregos e parafusos. }\end{array}$ \\
\hline Estrutura Metálica & $\begin{array}{l}\text { Forte candidato para reutilização } \\
\text { Mais utilizado na reciclagem do que reutilização } \\
\text { Estrutura parafusada facilita a desconstrução, mas as peças } \\
\text { precisam ser específicas para os parafusos } \\
\text { Desenvolver novos tipos de ligações e evitar soldagem seria uma } \\
\text { melhor solução } \\
\text { Evitar pisos soldados ou moldados no local } \\
\text { Limitar número de formatos das peças } \\
\text { Utilizar peças modulares } \\
\text { Buscar alternativas para produtos químicos anti-chamas }\end{array}$ \\
\hline Pedras e Alvenaria & $\begin{array}{l}\text { Tem grande histórico de reuso } \\
\text { Duráveis e fáceis de desconstruir, quando não são ligadas por } \\
\text { cimento } \\
\text { Dificuldade de separar argamassa de cimento dos tijolos } \\
\text { Tijolos maciços são bastante reutilizados } \\
\text { Priorizar argamassa de cal no lugar de argamassa de cimento } \\
\text { Atualmente, como é utilizado, não é uma boa escolha para o } \\
\text { desmonte, mas novas maneiras de construir com estes materiais } \\
\text { podem ser uma boa opção. }\end{array}$ \\
\hline Concreto & $\begin{array}{l}\text { É o sistema estrutural mais desafiador para futuro reuso } \\
\text { A estrutura se torna uma única peça que não se separa } \\
\text { É pesado e difícil de mover } \\
\text { Por fora é difícil analisar sua composição e verificar o que tem por } \\
\text { dentro das peças } \\
\text { Reuso é improvável, assim a melhor opção é a reciclagem } \\
\text { Concreto pré-fabricado oferece melhores condições de reuso, } \\
\text { devido à padronização e normalmente são ligados por conectores } \\
\text { ou encaixes } \\
\text { Evitar peças moldadas no local } \\
\text { Evitar fundações e subsolo }\end{array}$ \\
\hline
\end{tabular}

Fonte: Webster e Costello (2005) 
Na tabela 7 é possível perceber algumas diferenças que podem contribuir ou dificultar o processo do desmonte. No desenvolvimento do Projeto para o Desmonte é imprescindível analisar as características do sistema estrutural escolhido para obter melhores resultados no futuro. Para Webster e Costello (2005) é importante selecionar materiais com potencial para reuso atualmente, no entanto podem surgir novas técnicas para reaproveitamento no futuro, mas é melhor considerar as disponíveis hoje em dia.

Os autores citam um exemplo de uma construção tradicional na Nova Inglaterra de madeira e tijolos. Entre o fim dos anos 1800 e começo de 1900, esse tipo de construção era muito comum. Esses prédios são facilmente adaptáveis devido ao seu simples layout simples, transparência e regularidade. Os edifícios desta época eram construídos com paredes externas de alvenaria, pisos e colunas de madeira. Todos estes componentes podem ser facilmente separados sem danos significativos e reutilizados. A argamassa utilizada para ligar os tijolos é fácil de remover e estes materiais têm valor de revenda no mercado atual.

Dessa maneira se torna clara a importância de considerar o sistema estrutura no projeto para o desmonte. É importante considerar todas estas características para obter resultados satisfatórios na desmontagem e reduzir ao máximo a quantidade de materiais que ser tornam inutilizadas.

Diversos autores concordam com as mesmas características relacionadas ao projeto para o Desmonte na Construção Civil. A tabela 8 mostra os pontos em comum dos autores mais citados nesta revisão.

Tabela 8 Conceitos que contribuem para o Projeto para o Desmonte de diversos autores 


\begin{tabular}{|c|c|}
\hline Desmonte & \\
\hline Projetar de maneira sustentável & Crowther (2005) \\
\hline Considerar as diferentes camadas do edifício & $\begin{array}{c}\text { Crowther (2005); Heriqson, Rocha e Sattler } \\
\text { (2008); Guy e Shell (2002); Webster e } \\
\text { Costello (2005) }\end{array}$ \\
\hline $\begin{array}{c}\text { Considerar a hierarquia de diferentes tipos de } \\
\text { materiais e componentes. }\end{array}$ & Crowther (2005) \\
\hline $\begin{array}{l}\text { Entender que o edifício é uma composição de } \\
\text { componentes e materiais }\end{array}$ & $\begin{array}{l}\text { Heriqson, Rocha e Sattler (2008); Crowther } \\
\text { (2005) }\end{array}$ \\
\hline $\begin{array}{l}\text { Considerar os diferentes ciclos-de-vida dos } \\
\text { materiais e componentes da edificação. }\end{array}$ & Crowther (2005); Guy e Shell (2002) \\
\hline $\begin{array}{l}\text { A maneira com que o edifício é construído } \\
\text { influencia na desconstrução }\end{array}$ & $\begin{array}{l}\text { Heriqson, Rocha e Sattler (2008); Guy e Shell } \\
\text { (2002); Webster e Costello (2005) }\end{array}$ \\
\hline Projetar considerando o desmonte & $\begin{array}{l}\text { Heriqson, Rocha e Sattler (2008); Guy e Shell } \\
\text { (2002); Webster e Costello (2005) }\end{array}$ \\
\hline Utilizar peças e $n$ & $\begin{array}{l}\text { Heriqson, Rocha e Sattler (2008); Guy e Shell } \\
\text { (2002); Webster e Costello (2005) }\end{array}$ \\
\hline $\begin{array}{c}\text { Buscar realizar conexões com parafusos e } \\
\text { encaixes }\end{array}$ & $\begin{array}{c}\text { Heriqson, Rocha e Sattler (2008); Crowther } \\
\text { (1999); Guy e Shell (2002); Webster e } \\
\text { Costello (2005) }\end{array}$ \\
\hline Evitar ligações químicas & $\begin{array}{c}\text { Heriqson, Rocha e Sattler (2008); Crowther } \\
\text { (1999); Guy e Shell (2002); Webster e } \\
\text { Costello (2005) }\end{array}$ \\
\hline Propor ligações independentes & Heriqson, Rocha e Sattler (2008) \\
\hline $\begin{array}{l}\text { Utilizar peças de fácil manuseio, transporte e } \\
\text { armazenamento }\end{array}$ & $\begin{array}{l}\text { Heriqson, Rocha e Sattler (2008); Crowther } \\
\text { (1999); Guy e Shell (2002) }\end{array}$ \\
\hline $\begin{array}{l}\text { Facilitar o acesso em todas as partes da } \\
\text { edificação }\end{array}$ & $\begin{array}{l}\text { Heriqson, Rocha e Sattler (2008); Crowther } \\
\text { (1999); Guy e Shell (2002) }\end{array}$ \\
\hline Reutilizar materiais nas novas construções & $\begin{array}{l}\text { Heriqson, Rocha e Sattler (2008); Webster e } \\
\text { Costello (2005) }\end{array}$ \\
\hline Separar estrutura & $\begin{array}{l}\text { Crowther (1999); Guy e Shell (2002); Webste } \\
\text { e Costello (2005) }\end{array}$ \\
\hline Compatibilizar os sistemas & Crowther (1999) \\
\hline Identificação dos materiais e componentes & $\begin{array}{l}\text { Crowther (1999); Guy e Shell (2002); Webste } \\
\text { e Costello (2005) }\end{array}$ \\
\hline $\begin{array}{l}\text { Utilizar áreas comuns dos edifícios e fazer } \\
\text { com que o usuário participe do processo }\end{array}$ & Crowther (1999) \\
\hline $\begin{array}{l}\text { Permitir que os componentes fossem } \\
\text { desmontados simultaneamente }\end{array}$ & Crowther (1999) \\
\hline Adotar sistemas abertos & Yuba (2005); Webster e Costello (2005) \\
\hline $\begin{array}{l}\text { Facilitar a ligação das peças e montagem dos } \\
\text { componentes }\end{array}$ & $\begin{array}{l}\text { Yuba (2005); Guy, Shell (2002); Webster e } \\
\text { Costello (2005) }\end{array}$ \\
\hline Utilizar parafusos e conexões que não & Heriqson, Rocha, Sattler (2008); Guy e Shell \\
\hline
\end{tabular}




\begin{tabular}{|c|c|}
\hline danifiquem os elementos & (2002); Webster e Costello (2005) \\
\hline $\begin{array}{l}\text { Utilizar materiais e componentes resistentes } \\
\text { e duráveis }\end{array}$ & $\begin{array}{l}\text { Heriqson, Rocha, Sattler (2008); Guy e Shell } \\
\text { (2002); Webster e Costello (2005) }\end{array}$ \\
\hline $\begin{array}{l}\text { Não utilizar materiais danosos ao meio } \\
\text { ambiente }\end{array}$ & Guy e Shell (2002); Webster e Costello (2005) \\
\hline Evitar embutir sistemas hidráulicos e elétricos & Guy e Shell (2002); Webster e Costello (2005) \\
\hline $\begin{array}{c}\text { Concentrar no mesmo local os subsistemas, } \\
\text { como hidráulico e elétrico }\end{array}$ & Guy e Shell (2002) \\
\hline $\begin{array}{l}\text { Utilizar materiais e componentes que possam } \\
\text { se sustentar independentes }\end{array}$ & Guy e Shell (2002) \\
\hline $\begin{array}{l}\text { Utilizar elementos compatíveis à escala } \\
\text { humana }\end{array}$ & Guy e Shell (2002) \\
\hline Utilizar materiais leves e modulares & Guy e Shell (2002); Webster e Costello (2005) \\
\hline $\begin{array}{l}\text { Utilizar materiais que possam ser } \\
\text { identificados visualmente }\end{array}$ & Webster e Costello (2005) \\
\hline $\begin{array}{l}\text { Utilizar número limitado de diferentes } \\
\text { componentes }\end{array}$ & Webster e Costello (2005) \\
\hline Utilizar materiais que são fáceis de separar & Webster e Costello (2005) \\
\hline Evitar edificações complexas & Webster e Costello (2005) \\
\hline $\begin{array}{l}\text { Evitar misturar diferentes sistemas } \\
\text { construtivos }\end{array}$ & Webster e Costello (2005) \\
\hline Projetar layout simples e regular & Webster e Costello (2005) \\
\hline Guardar com segurança o projeto "as built" & Webster e Costello (2005) \\
\hline
\end{tabular}

Assim, quando estas questões relacionadas ao Projeto para o Desmonte são consideradas desde a concepção inicial das construções, é possível obter melhores resultados na aplicação desta ferramenta. Dessa maneira é possível contribuir com a recuperação de materiais, redução de desperdício e consequentemente com o desenvolvimento sustentável. 


\section{MATERIAS E MÉTODOS DE PESQUISA}

Neste capítulo serão detalhados os procedimentos de pesquisa e os critérios que serão utilizados para analisar e sistematizar os casos. A pesquisa se iniciou com intensa revisão bibliográfica, pesquisa em livros, artigos, teses, dissertações, entre outros documentos. Posteriormente foram realizados estudos empíricos, entre eles estudos de casos e exploratórios, com o objetivo de reunir informações práticas.

\subsection{Revisão Bibliográfica}

Foi realizado o levantamento de livros, teses, dissertações e artigos em anais de congressos e periódicos nacionais e internacionais nas bases Dedalus ${ }^{7}$ - Biblioteca da USP , Scopus ${ }^{8}$, InfoHAB ${ }^{9}$, Periódicos Capes $^{10}$ e Web of Knowledge ${ }^{11}$. As palavras chaves e expressões utilizadas diretamente ligadas ao tema específico foram: arquitetura sustentável / sustainable architecture, desenvolvimento sustentável / sustainable development, projeto para o desmonte / design for disassembly, projeto para a desconstrução / design for deconstruction, projeto para o X / design for X, Análise do Ciclo de Vida (ACV) / Life Cycle Assessment (LCA), green architecture, demolição / demolition, reutilização de materiais / materials reuse, reciclagem de materiais / recycle materials, estrutura em madeira, estrutura metálica, resíduos na construção civil, entre outros.

\footnotetext{
${ }^{7}$ http://dedalus.usp.br:

${ }^{8}$ http://www.scopus.com

${ }^{9}$ http://www.infohab.org.br

10http://www.periodicos.capes.gov.br.

$11 \mathrm{http}: / /$ apps.webofknowledge.com
} 
Foram encontrados diversos trabalhos nacionais e internacionais, artigos, dissertações, teses, documentos, sobre arquitetura sustentável, o ciclo de vida de diversos materiais, desenvolvimento sustentável em diversos setores (não apenas na construção civil, mas também em outras indústrias), processo de projeto, Projeto para "X", Projeto para Desmonte, Demolição.

Na tabela 9 consta o número aproximado de referências bibliográficas para 0 desenvolvimento desta dissertação.

Tabela 9 Dados sobre a Revisão Bibliográfica

\begin{tabular}{cc}
\hline Fonte & Quantidade \\
\hline Livros & 20 \\
\hline Artigos Nacionais & 30 \\
\hline Artigos Internacionais & 24 \\
\hline Sites & 14 \\
\hline Normas & 06 \\
\hline Dissertações e Teses & 10 \\
\hline Outros & 10 \\
\hline
\end{tabular}

Para Gil (2002) a pesquisa bibliográfica é desenvolvida com base em material já elaborado, constituído principalmente de livros e artigos científicos. O autor confirma a importância desse método afirmando que a principal vantagem da pesquisa bibliográfica reside no fato de permitir ao investigador a cobertura de uma gama de fenômenos muito mais ampla do que aquela que poderia pesquisar diretamente.

Ao longo da pesquisa bibliográfica foi possível analisar as diversas questões relacionadas ao tema deste trabalho. Foi essencial para obter informações sobre o que é abordado no Brasil e no Mundo. Através da revisão foi possível obter informações sobre os pontos mais importantes que devem ser analisados no desmonte e desconstrução, além de avaliar o impacto das duas ações em relação ao meio 
ambiente. Assim foi possível selecionar os casos empíricos que contribuíram com o trabalho.

\subsection{Estudos Empíricos}

Após a seleção e leitura do material bibliográfico, foi necessário colher dados para desenvolver a segunda parte da dissertação, onde são analisadas questões práticas. Gil (2002) cita alguns métodos para colher dados:

\footnotetext{
"Para coleta de dados nos levantamentos são utilizadas as técnicas de interrogação: o questionário, a entrevista e o formulário. Por questionário entende-se um conjunto de questões que são respondidas por escrito pelo pesquisando. Entrevista, por sua vez, pode ser entendida com a técnica que envolve duas pessoas numa situação "face a face" e em que uma delas formula questões e a outra responde. Formulário, por fim, pode ser definido como a técnica de coleta de dados em que o pesquisador formula questões previamente elaboradas e anota as respostas."
}

Nos estudos os principais métodos para colher dados foram: entrevistas, questionário, observação direta e análise de documentos.

Inicialmente foram selecionados três estudos exploratórios para desenvolver a parte prática da pesquisa. Gil (2002) define que as pesquisas que têm como objetivo proporcionar maior intimidade com o a questão e busca torna-lo mais evidente ou desenvolver hipóteses, podem ser classificadas como estudos exploratórios.

Portanto, primeiramente foram estudadas construções em que foi possível reutilizar materiais, como estrutura de madeira e metálica, com o objetivo de analisar como puderam ser reaproveitados e quais as dificuldades. Dessa maneira foi observado como a demolição ou a desmontagem podem influenciar no processo. 
Outro estudo exploratório realizado foi sobre Desmontagem Controlada, uma maneira de desmontar uma construção em que não foi considerada a desmontagem no seu projeto. O objetivo principal deste estudo foi verificar como e porquê este tipo de intervenção é feita, além de analisar maneira para que o projeto possa contribuir no processo.

Além destes estudos exploratórios, foram realizados dois estudos de caso, um sobre uma demolição convencional e outro sobre a desmontagem de um protótipo de uma residência (Eko House). Para (Yin, 2005) geralmente o estudo de caso é uma estratégia quando há questões em relação a "como" e "por que", quando o foco da pesquisa se encontra em fenômenos contemporâneos que estão inseridos em algum contexto da realidade atual.

Segundo o autor:

"O estudo de caso é uma estratégia escolhida ao se examinarem acontecimentos contemporâneos, mas quando não se podem manipular comportamentos relevantes. O estudo de caso consta com muitas das técnicas utilizadas pelas pesquisas históricas, mas acrescenta duas fontes de evidências que usualmente não são incluídas no repertório de um historiador: observação direta dos acontecimentos que estão sendo estudados e entrevistas das pessoas neles envolvidas."

O estudo de caso se inicia buscando fontes de evidências. As mais comuns são: documentação, registros em arquivos, entrevistas, observação direita, observação participante e artefatos físicos (YIN, 2005). Ao longo da coleta de dados, para o autor é importante seguir três princípios: utilizar várias fontes de evidências, criar um banco de dados e manter o encadeamento de evidências.

Assim, serão apresentados dois estudos de caso, um sobre demolição convencional, onde algumas partes são desmontadas para futura revenda e outro que relata a 
construção de um protótipo de uma residência que depois foi desmontada para ser remontada em outro local.

Apesar de todos os estudos buscarem informações de "como" e "porquê" o processo é realizado, contarem com diversas fontes de informações e serem acontecimentos contemporâneos, a principal característica que define a separação entre os estudos de caso e exploratórios é a questão da observação direta. Nos estudos exploratórios não foi possível observar o processo de desmontagem ou demolição e reutilização dos materiais. Estas pesquisas foram realizadas após o processo ter sido finalizado. No caso da demolição convencional da obra comercial e da desmontagem da Eko House, foi possível acompanhar o processo.

As fontes de evidência utilizadas nos diversos estudos estão detalhadas na tabela 10 .

Tabela 10 Fontes de Evidências dos Estudos

\begin{tabular}{|c|c|c|}
\hline Estudos & Evidências & Classificação do Estudo \\
\hline \multirow[t]{4}{*}{ Demolição Convencional } & Entrevistas & Estudo de Caso \\
\hline & Visita ao local & \\
\hline & Imagens fotográficas & \\
\hline & Acompanhamento da demolição & \\
\hline \multirow[t]{2}{*}{ Demolição Controlada } & Entrevista & Estudo Exploratório \\
\hline & Análise de Imagens e documentos & \\
\hline Reutilização de Estrutura & Entrevista & Estudo Exploratório \\
\hline \multirow[t]{3}{*}{ em Madeira } & Visitas ao local & \\
\hline & Imagens fotográficas & \\
\hline & $\begin{array}{l}\text { Análise de documentos: projetos e } \\
\text { maquete }\end{array}$ & \\
\hline Reutilização de Estrutura & Entrevista & Estudo Exploratório \\
\hline \multirow[t]{3}{*}{ Metálica } & Visitas ao local & \\
\hline & Imagens fotográficas & \\
\hline & $\begin{array}{l}\text { Análise de documentos: projetos e } \\
\text { maquete }\end{array}$ & \\
\hline \multirow[t]{4}{*}{ Desmontagem Eko House } & Entrevista & Estudo de Caso \\
\hline & Visitas ao local & \\
\hline & Imagens fotográficas & \\
\hline & $\begin{array}{l}\text { Acompanhamento } \\
\text { desmontagem }\end{array}$ & \\
\hline
\end{tabular}


A realização de diversos estudos foi necessária, pois a intenção foi abordar as diversas medidas tomadas, atualmente, no fim da vida útil das edificações. Assim, buscaram-se informações sobre "como" e "porquê" são feitas as demolições ou possíveis desmontagem, além de analisar o impactos destas decisões.

Os estudos são de naturezas diferentes, no entanto, complementares, pois a reunião destas informações foi essencial para confrontar a revisão bibliográfica e propor as diretrizes para o Projeto para o Desmonte, que faz parte do objetivo deste trabalho.

Para Yin (2005):

"Em geral, os estudos de caso representam a estratégia preferida quando se colocam questões do tipo "como" e "por que", quando o pesquisador tem pouco controle sobre os acontecimentos e quando o foco se encontra em fenômenos contemporâneos inseridos em algum contexto da vida real. Pode-se complementar esses estudos de casos explanatórios com dois outros tipos estudos exploratórios e descritivos."

Assim, neste trabalho, os estudos exploratórios complementam os estudos de casos, além de acrescentar diversas informações sobre demolição e desmontagem. A seguir serão apresentados, de maneira mais detalhada, os métodos de pesquisa de cada estudo.

\subsubsection{Demolição Convencional}

Este estudo de caso é sobre uma demolição considerada convencional ${ }^{12}$, de um edifício comercial térreo. O objetivo desta análise é verificar como as demolições estão sendo realizadas, quais materiais tem mais possibilidades de serem aproveitados e quais são

\footnotetext{
12 Foi considerada convencional, pois é a mais comum na região, construções com estrutura em concreto armado, paredes em alvenaria e telhado com peças cerâmicas e estrutura de madeira.
} 
descartados como entulhos. Além disso, foi interessante analisar como as conexões e as relações entre os materiais contribuem ou dificultam com o processo.

A tabela 11 demonstra as atividades realizadas ao longo deste estudo de caso.

Tabela 11 Atividades Realizadas relacionadas ao Estudo de Caso da Demolição Convencional

\begin{tabular}{|c|c|c|c|}
\hline Data & $\begin{array}{l}\text { Atividade } \\
\text { Realizada }\end{array}$ & $\begin{array}{l}\text { Definição } \\
\text { Atividade }\end{array}$ & Resultados \\
\hline $31 / 01 / 2012$ & $\begin{array}{lr}\text { Levantamento } & \text { de } \\
\text { demolidoras } & \text { em } \\
\text { Ribeirão Preto } & \end{array}$ & $\begin{array}{l}\text { Pesquisas na internet, } \\
\text { listas telefônicas e } \\
\text { indicações de pessoas }\end{array}$ & encontradas 4 empresas \\
\hline $31 / 01 / 2012$ & $\begin{array}{lr}\text { Levantamento } & \text { de } \\
\text { demolidoras } & \text { em } \\
\text { São Carlos } & \end{array}$ & $\begin{array}{l}\text { Pesquisas na internet, } \\
\text { listas telefônicas e } \\
\text { indicações de pessoas }\end{array}$ & Foram encontradas 4 empresas \\
\hline $31 / 01 / 2012$ & $\begin{array}{lr}\text { Levantamento } & \text { de } \\
\text { demolidoras } & \text { em } \\
\text { São Paulo } & \end{array}$ & $\begin{array}{l}\text { Pesquisas na internet, } \\
\text { listas telefônicas e } \\
\text { indicações de pessoas. }\end{array}$ & $\begin{array}{lll}\text { Foram } & \text { encontradas } & 20 \\
\text { empresas } & & \\
\end{array}$ \\
\hline $09 / 02 / 2012$ & $\begin{array}{l}\text { Contato com } \\
\text { demolidoras em } \\
\text { Ribeirão Preto / } \\
\text { Visita aos galpões } \\
\begin{array}{ll}\text { de três } \\
\text { demolidoras }\end{array}\end{array}$ & $\begin{array}{lrr}\text { Definir obra } & \text { de } \\
\text { demolição } & \text { a } & \text { ser } \\
\text { acompanhada } & \end{array}$ & $\begin{array}{l}\text { Conversa com funcionários e } \\
\text { proprietários da empresa que } \\
\text { realiza a demolição. } \\
\text { Análise dos materiais } \\
\text { removidos de construções que } \\
\text { estavam em estoque para } \\
\text { revenda. }\end{array}$ \\
\hline $20 / 06 / 2012$ & $\begin{array}{l}\text { Acompanhamento } \\
\text { da demolição da } \\
\text { obra em Ribeirão } \\
\text { Preto }\end{array}$ & $\begin{array}{lr}\text { Visitar a } & \text { obra } \quad \text { e } \\
\text { entrevista } & \text { com } \\
\text { funcionários. } & \end{array}$ & $\begin{array}{l}\text { Análise dos materiais que } \\
\text { podem ser aproveitados e dos } \\
\text { que são descartados. } \\
\text { Acompanhar as etapas da } \\
\text { demolição. }\end{array}$ \\
\hline $21 / 06 / 2012$ & $\begin{array}{l}\text { Acompanhamento } \\
\text { da demolição da } \\
\text { obra em Ribeirão } \\
\text { Preto e contato } \\
\text { com o Ademir, por } \\
\text { telefone, } \\
\text { responsável pela } \\
\text { empresa }\end{array}$ & $\begin{array}{l}\text { Visitar a obra a ser } \\
\text { demolida e entrevista } \\
\text { com o responsável pela } \\
\text { demolição. }\end{array}$ & $\begin{array}{l}\text { Análise dos materiais que } \\
\text { podem ser aproveitados e dos } \\
\text { que são descartados. } \\
\text { Acompanhar as etapas da } \\
\text { demolição. } \\
\text { Reunião de informações } \\
\text { obtidas através de entrevista } \\
\text { como responsável. }\end{array}$ \\
\hline $22 / 06 / 2012$ & $\begin{array}{l}\text { Acompanhamento } \\
\text { da demolição da } \\
\text { obra em Ribeirão } \\
\text { Preto }\end{array}$ & $\begin{array}{l}\text { Visitar a obra a ser } \\
\text { demolida e observações } \\
\text { sobre maneira de } \\
\text { demolir e manuseio dos }\end{array}$ & $\begin{array}{l}\text { Observar materiais e } \\
\text { componentes que moram } \\
\text { removidos para futura revenda. } \\
\text { Análise do que dificulta ou }\end{array}$ \\
\hline
\end{tabular}




\begin{tabular}{|c|c|c|c|}
\hline & & materiais. & facilita o processo. \\
\hline $29 / 06 / 2012$ & $\begin{array}{l}\text { Acompanhamento } \\
\text { da demolição da } \\
\text { obra em Ribeirão } \\
\text { Preto e entrevista } \\
\text { com funcionários. }\end{array}$ & $\begin{array}{l}\text { Visitar a obra a ser } \\
\text { demolida e observações } \\
\text { sobre maneira de } \\
\text { demolir e manuseio dos } \\
\text { materiais. }\end{array}$ & $\begin{array}{l}\text { Observar materiais e } \\
\text { componentes que moram } \\
\text { removidos para futura revenda. } \\
\text { Análise do que dificulta ou } \\
\text { facilita o processo. }\end{array}$ \\
\hline $30 / 06 / 2012$ & $\begin{array}{l}\text { Acompanhamento } \\
\text { da demolição da } \\
\text { obra em Ribeirão } \\
\text { Preto, entrevista } \\
\text { com funcionário e } \\
\text { contratantes. }\end{array}$ & $\begin{array}{l}\text { Acompanhamento } \\
\text { durante toda a manhã, } \\
\text { por } 5 \text { hrs, da demolição } \\
\text { e retirada dos entulhos. }\end{array}$ & $\begin{array}{llll}\text { Reunir informações } & \text { e } \\
\text { documentar o processo } & \text { de } \\
\text { demolição e } & \text { retirada } & \text { de } \\
\text { entulhos. } & & & \\
\end{array}$ \\
\hline
\end{tabular}

Nesta tabela é possível ver as fontes de análise: levantamento das demolidoras, visitas aos depósitos, entrevistas com funcionários, responsável pela empresa e contratante do serviço, além de visitas ao local e acompanhamento da demolição.

Nas visitas aos depósitos das demolidoras foi possível observar quais os materiais eles costumam desmontar e armazenar para futura revenda. Foram visitadas 3 empresas, em uma delas não havia depósitos, na outra um pequeno e na terceira grande quantidade de material era estocada.

Nas entrevistas realizadas com funcionários foi possível obter informações sobre os tipos de demolições que realizam e como costumam ser feitas. Na visita ao local foi observados o tipo de construção e os materiais. Ao longo do acompanhamento da desmontagem e demolição foi possível observar diversas questões abordadas ao longo do trabalho. Neste caso não foi possível obter documentos em relação ao edifício ou demolição. 


\subsubsection{Demolição Controlada}

Este tipo de Demolição é realizada quando não se pode derrubar todo o edifício, nem implodi-lo, por diversas razões. É uma maneira de desmontar toda a construção ou parte dela. Assim, este estudo demonstra a importância de considerar maneiras de desmontar a construção desde a concepção do projeto.

Inicialmente foi realizado um levantamento sobre as empresas que fazem este trabalho, posteriormente, houve o contato com três empresas e foi enviado um questionário sobre o tema para que fosse respondido. Duas delas responderam. $\mathrm{A}$ empresa eleita para a pesquisa foi a que mais tinha informações sobre obras que pudessem contribuir com a pesquisa.

Dessa maneira, foi realizada uma entrevista, que durou em torno de 3 horas, sobre como é realizado este processo. Esta foi a principal fonte de evidencia deste caso, pois foi apresentada uma obra interessante, onde no projeto havia uma previsão de ampliação, mas não a maneira que seria realizada. Assim, a única opção seria a Demolição Programada, através da técnica de corte adiamantado. Este caso complementa a pesquisa, pois demonstra na prática ferramentas e tecnologias que tiveram que se adaptar à falta do Projeto para o Desmonte.

Na tabela 12 constam as atividades realizadas relacionadas a este estudo.

Tabela 12 Atividades Realizadas relacionadas ao Estudo Exploratório de Demolição Programada

\begin{tabular}{|c|c|c|c|}
\hline Data & Atividade Realizada & $\begin{array}{l}\text { Definição da } \\
\text { Atividade }\end{array}$ & Res \\
\hline $28 / 05 / 2012$ & $\begin{array}{l}\text { Levantamento sobre empresas } \\
\text { que realizam Desmontagem } \\
\text { Controlada, em SP. }\end{array}$ & $\begin{array}{l}\text { Pesquisa para levantar } \\
\text { contatos da empresa. }\end{array}$ & $\begin{array}{l}\text { Reunir dados sobre } \\
\text { as empresas }\end{array}$ \\
\hline $01 / 06 / 2012$ & $\begin{array}{l}\text { Envio de questionário sobre } \\
\text { desmontagem controlada para } \\
\text { quatro empresas. }\end{array}$ & $\begin{array}{l}\text { Questionário } \\
\text { desenvolvido com o } \\
\text { objetivo de discutir }\end{array}$ & $\begin{array}{lr}\text { Respostas de } & \text { duas } \\
\text { empresas } & \text { com } \\
\text { esclarecimento do }\end{array}$ \\
\hline
\end{tabular}




\begin{tabular}{|c|c|c|c|}
\hline & & $\begin{array}{l}\text { questões sobre } \\
\text { desmontagem } \\
\text { controlada }\end{array}$ & $\begin{array}{l}\text { processo e seleção } \\
\text { da empresa para } \\
\text { entrevista. }\end{array}$ \\
\hline $15 / 06 / 2012$ & $\begin{array}{l}\text { Entrevista com engenheiro } \\
\text { responsável de uma empresa } \\
\text { que realiza a desmontagem } \\
\text { controlada. }\end{array}$ & $\begin{array}{l}\text { Entrevista realizada } \\
\text { por } 4 \text { hrs, obtenção de } \\
\text { informações sobre o } \\
\text { processo } \\
\text { demolição. }\end{array}$ & $\begin{array}{l}\text { Esclarecimento do } \\
\text { processo de } \\
\text { desmontagem } \\
\text { controlada, reunião } \\
\text { de informações e } \\
\text { imagens para o } \\
\text { estudo exploratório. }\end{array}$ \\
\hline
\end{tabular}

Através das informações e documentos fornecidos pelo engenheiro, foi possível analisar a maiores dificuldades do processo.

\subsubsection{Reutilização de Estrutura de Madeira}

Este estudo exploratório foi o primeiro realizado para este trabalho. É sobre a sede de um clube de Golf, onde também funciona um restaurante. Esta obra foi escolhida por ter sido construída com madeiras reutilizadas de antigas tulhas de café. Assim foi possível observar quais foram os obstáculos para a reutilização dos materiais e quais os benefícios.

As tulhas quando foram construídas, não previam a desmontagem da estrutura, no entanto, foi possível desmontar e reutilizar. A madeira é um material nobre que pode ser utilizado de diversas maneiras e tem grande durabilidade.

As principais fontes de informações destes estudos foram: entrevistas com o autor do projeto de arquitetura e com o administrador do clube; reunião de documentos, como plantas, imagens da construção e maquete física; além de visitas ao local. Na tabela abaixo constam as atividades realizadas. 
Tabela 13 Atividades Realizadas relacionadas ao Estudo Exploratório de Reutilização de Estrutura de Madeira

\begin{tabular}{|c|c|c|c|}
\hline Data & Atividade Realizada & $\begin{array}{c}\text { Definição da } \\
\text { Atividade }\end{array}$ & Resultados \\
\hline $31 / 05 / 2011$ & $\begin{array}{l}\text { Entrevista com o } \\
\text { arquiteto responsável } \\
\text { pelo projeto. }\end{array}$ & $\begin{array}{l}\text { Entrevista realizada } \\
\text { com o autor do } \\
\text { projeto por } 2 \text { horas e } \\
\text { reunião } \\
\text { documentos. }\end{array}$ & $\begin{array}{l}\text { Obtenção de dados } \\
\text { para analise do } \\
\text { estudo. }\end{array}$ \\
\hline $31 / 05 / 2011$ & $\begin{array}{l}\text { Entrevista com o } \\
\text { administrador } \\
\text { clube. }\end{array}$ & $\begin{array}{l}\text { Entrevista realizada } \\
\text { com o administrador } \\
\text { do clube sobre a } \\
\text { construção } \\
\text { manutenção da obra. }\end{array}$ & $\begin{array}{l}\text { Obtenção de dados } \\
\text { para analise do } \\
\text { estudo. }\end{array}$ \\
\hline $31 / 05 / 2011$ & Visita ao clube. & $\begin{array}{l}\text { Visita ao local, após } 4 \\
\text { anos da conclusão da } \\
\text { obra, para verificar } \\
\text { possíveis informações } \\
\text { reunidas. }\end{array}$ & $\begin{array}{l}\text { Observação do } \\
\text { edifício e reunião } \\
\text { de informações e } \\
\text { dados para análise } \\
\text { do estudo. }\end{array}$ \\
\hline $17 / 08 / 2011$ & $\begin{array}{lr}\begin{array}{l}\text { Segunda } \\
\text { com ontrevista }\end{array} & \text { arquiteto } \\
\text { responsável } & \text { pelo } \\
\text { projeto. } & \end{array}$ & $\begin{array}{l}\text { Entrevista com } \\
\text { duração de } 2 \mathrm{hrs} \text { sobre } \\
\text { os conceitos do } \\
\text { projeto, e reutilização } \\
\text { de materiais. }\end{array}$ & $\begin{array}{l}\text { Reunião de dados e } \\
\text { documentos } \\
\text { (imagens } \\
\text { projetos), } \\
\text { aprofundar } \\
\text { estudo. }\end{array}$ \\
\hline
\end{tabular}

As atividades contribuíram para a obtenção de dados e informações sobre o processo de construção com reutilização de materiais. Este estudo foi imprescindível para analisar as possibilidades de reutilização de materiais como madeira, telhas e tijolos. Assim complementa os estudos de casos e auxiliou na elaboração das diretrizes.

\subsubsection{Reutilização de Estrutura Metálica}

Este foi outro estudo exploratório como o objetivo de complementar os estudos de casos e reunir mais informações sobre desmontagem e reutilização de materiais. Após realizado o estudo sobre estrutura de madeira, sentiu-se a necessidade de estudar outro tipo de estrutura para verificar quais seriam os resultados. 
A estrutura metálica analisada é a cobertura de uma quadra poliesportiva, localizada no campus da USP - SC. Antes esta mesma estrutura era utilizada para cobrir um Hangar. No entanto, não estava sendo utilizada e estava abandonada. Dessa maneira, decidiram desmontá-la e reutilizá-la integralmente no ginásio.

Apesar de não acompanhar o processo, pois a obra já estava finalizada, foi interessante observar como este material permite ser desmontado e totalmente remontado sem perdas. Várias características, como serem parafusadas, o material ser resistente, entre outras, contribuíram para isso. Abaixo segue as atividades realizadas.

Tabela 14 Atividades Realizadas relacionadas ao Estudo Exploratório de Reutilização de Estrutura Metálica

\begin{tabular}{|c|c|c|c|}
\hline Data & Atividade Realizada & Definição da Atividade & Resultados \\
\hline $07 / 10 / 2011$ & $\begin{array}{l}\text { Entrevista com arq. } \\
\text { Sonia Costardi sobre o } \\
\text { Ginásio do Campus da } \\
\text { USP }\end{array}$ & $\begin{array}{l}\text { Reunião de dados e } \\
\text { documentos para o estudo } \\
\text { de caso. }\end{array}$ & $\begin{array}{l}\text { Obtenção de } \\
\text { informações } \\
\text { relevantes do estudo } \\
\text { exploratório e reunião } \\
\text { de documentos. }\end{array}$ \\
\hline $07 / 10 / 2011$ & $\begin{array}{l}\text { Vista ao ginásio do } \\
\text { Campus da USP }\end{array}$ & $\begin{array}{l}\text { Análise do } \text { método } \\
\text { construtivo e observação } \\
\text { dos encaixes e peças } \\
\text { metálicas }\end{array}$ & $\begin{array}{lr}\text { Obtenção } & \text { de } \\
\text { informações } & \\
\text { relevantes do estudo } \\
\text { exploratório } \\
\text { verificação } \\
\text { estrutura. }\end{array}$ \\
\hline
\end{tabular}

As principais fontes de evidência para este estudo foi entrevista com arquiteta do Campus da USP-SC e visitas ao local. Através das informações reunidas foi possível analisar as possibilidades de reutilização do material e suas características, que colaboraram com a pesquisa.

\subsubsection{Desmontagem Eko House}

A desmontagem da Eko House, um protótipo de uma residência sustentável, foi construído para participar de um concurso na Espanha, sobre construção sustentável, 
além de várias características, como eficiência energética, materiais sustentáveis, entre outros, também deveria ser desmontada e montada no lugar do concurso.

Esta questão foi definitiva para abordar este estudo, pois é um caso muito difícil de encontrar atualmente no Brasil, onde uma residência é construída já pensando em sua desmontagem. Assim toda a estrutura, vedação, cobertura, sistemas elétricos e hidráulicos foram conectados considerando o futuro desmonte.

Assim foi uma grande fonte de informações sobre como projetar considerando o desmonte. Na tabela 15 constam as atividades realizadas.

Tabela 15 Atividades Realizadas relacionadas ao Estudo de Caso da Eko House

\begin{tabular}{|c|c|c|c|}
\hline Data & Atividade Realizada & Definição da Atividade & Resultados \\
\hline $13 / 06 / 2012$ & $\begin{array}{l}\text { Visita a Ekouse e } \\
\text { entrevista com a prof. } \\
\text { Cláudia Oliveira }\end{array}$ & $\begin{array}{l}\text { Visita ao protótipo da } \\
\text { residência, que ainda } \\
\text { estava em construção e } \\
\text { entrevista com uma das } \\
\text { professoras envolvidas no } \\
\text { projeto, duração de } 3 \\
\text { horas. }\end{array}$ & $\begin{array}{l}\text { Entender } \\
\text { conceitos do projeto } \\
\text { e ver como o } \\
\text { protótipo estava } \\
\text { sendo construído, } \\
\text { isto facilitou para } \\
\text { compreender como } \\
\text { foi feita } \\
\text { desmontagem. }\end{array}$ \\
\hline 23 a $25 / 07 / 2012$ & $\begin{array}{l}\text { Acompanhamento da } \\
\text { desmontagem da Eko } \\
\text { house. }\end{array}$ & $\begin{array}{l}\text { Entevistas com operários } \\
\text { e estudantes, } \\
\text { acompanhamento } \\
\text { desmontagem } \\
\text { estrutura. }\end{array}$ & $\begin{array}{l}\text { Analise do sistema } \\
\text { de desmontagem, } \\
\text { reunião de } \\
\text { importantes } \\
\text { informações. }\end{array}$ \\
\hline
\end{tabular}

Através da entrevista, acompanhamento da construção e desmontagem, foi possível observar algumas questões ligadas à desmontagem da construção. A análise deste estudo de caso contribuiu para verificar questões abordadas em projeto que colaboraram para a desmontagem sem danificar os elementos da construção. 


\section{PESQUISA DESCRITIVA - ESTUDOS EMPÍRICOS}

Neste capítulo são apresentados estudos de campo, com diferentes propostas, para analisar diversas características e materiais. Além disso, será possível obter informações para futura aplicação do conceito do Projeto para o Desmonte por arquitetos com intenção de utilizar esta ferramenta, no setor da construção civil.

Como mencionado anteriormente, não foi possível acompanhar um projeto que incorporasse o Projeto para o Desmonte e posteriormente analisar sua construção, desmonte e reutilização dos materiais e elementos. Isto por dois motivos, pelo limite de tempo do mestrado, pois levariam anos para acompanhar todo o processo. Outro motivo, apresentado na revisão bibliográfica e confirmado nas entrevistas, é que não é comum os projetistas considerarem este conceito no desenvolvimento do projeto.

Neste capítulo serão apresentados cinco estudos empíricos. Inicialmente será apresentado o estudo de caso de uma demolição considerada convencional, com estrutura de concreto armado, alvenaria de tijolos de barro, e telhado com estrutura de madeira e telhas de barro. Neste caso será possível observar as consequências da falta do projeto para o desmonte na concepção inicial do edifício, mas também como podem ser removidos os materiais e quais as características que contribuem ou dificultam o desmonte.

Em seguida, será relatado um estudo, de carácter exploratório, em que foi utilizada a técnica de demolição programada, para demonstrar a necessidade de desenvolver novas tecnologias que se adaptam ao fato do projeto da construção não prever o desmonte e assim enfatizar a necessidade de incorporar o conceito no desenvolvimento do projeto. 
Nos dois seguintes, são construções onde materiais foram reutilizados de edificações anteriores. Assim foi possível avaliar como os materiais foram reaproveitados e os resultados obtidos.

Por fim, será analisado outro estudo de caso onde foi considerado o desmonte desde a concepção do projeto. Neste os elementos da construção foram desmontados, não para serem reutilizados em outras construções, mas para serem remontados em outro local. Este estudo foi essencial para analisar características que contribuem com o desmonte com excelente resultado.

Com a análise desses estudos de caso e exploratórios foi possível verificar características que contribuem ou que dificultam a desmontagem das edificações, assim contribuíram para formar diretrizes para o Projeto para o Desmonte na construção civil. Os resultados das análises e as diretrizes serão apresentados no próximo capítulo.

\subsection{Demolição Convencional}

Foi acompanhada a demolição de um edifício comercial de estrutura convencional (estrutura em concreto, vedação em alvenaria e cobertura de madeira com telhas cerâmicas). Alguns materiais foram separados e levados para o depósito da demolidora, com o intuito de serem revendidos, no entanto grande parte da estrutura foi removida como entulho.

Foram pesquisadas demolidoras em São Carlos, por ser o local de desenvolvimento da pesquisa; em Ribeirão Preto, por ser a cidade de origem da autora, além de ser uma das principais cidades da região, em termos populacional e econômico; e em São Paulo, a capital do estado. Foi escolhida uma demolição em Ribeirão Preto, por ter 
mais oportunidades de acompanhar e encontrar uma demolição de uma construção convencional, que não fosse de uma grande construção. Pois a ideia foi analisar questões que possam aplicar nas construções de médio e pequeno porte, por ser a grande maioria em Ribeirão Preto e São Carlos, onde foram realizadas as pesquisas.

Em Ribeirão Preto, através de pesquisas na Internet, lista telefônica e indicações de construtores, foram identificadas três principais demolidoras. Foram realizadas visitas aos seus depósitos e entrevistas, assim foi selecionada apenas uma delas, por ser a mais atuante no mercado e a que possui maior estoque de materiais para revenda.

A escolha da obra a ser acompanhada, foi devido aos seus materiais, que são muito utilizados atualmente: concreto armado, telhas metálicas, telhas cerâmicas fixadas em estrutura de madeira, alvenaria, caixilhos de alumínio com vidro temperado, revestimentos cerâmicos e forros de gesso.

Foram realizadas entrevistas com os agentes envolvidos no processo (proprietário do terreno, responsável pela demolição e operários), além de visitas ao local e acompanhamento da demolição.

Nesta obra foi possível reaproveitar a madeira que estruturava o telhado, os caixilhos de vidro temperado, alguns canos de PVC, elementos metálicos que revestiam a fachada, caixa d água e louças. Os vidros comuns, telhas, revestimentos, gesso, estrutura, elementos elétricos, não foram reutilizados. Na tabela 16 é possível ver quais os materiais e componentes que puderam ser aproveitados e os que foram retirados como entulhos.

Tabela 16 Materiais que puderam ser aproveitados para futura revenda e materiais que se transformaram em entulhos. 


\begin{tabular}{lll}
\hline Peças estruturais de Madeira & $\mathrm{X}$ & $\mathrm{X}$ \\
\hline Vidro Comum & $\mathrm{X}$ & \\
\hline Vidro Temperado & & \\
\hline Sistema Elétrico & $\mathrm{X}$ & \\
\hline $\begin{array}{l}\text { Sistema Hidráulico (Tubos de } \\
\text { PVC) }\end{array}$ & $\mathrm{X}$ & \\
\hline Caixa d'água & $\mathrm{X}$ & $\mathrm{X}$ \\
\hline Painéis Metálicos (fachada) & & $\mathrm{X}$ \\
\hline Telhas cerâmicas & & $\mathrm{X}$ \\
\hline Revestimentos & & $\mathrm{X}$ \\
\hline Concreto armado (estrutura) & & \\
\hline Gesso (paredes e forro) & & \\
\hline
\end{tabular}

Os materiais a serem reutilizados foram removidos com ferramentas padrões, como marretas, separados em obra e levados para o depósito da demolidora, para revenda. Durante uma semana, três funcionários da demolidora retiraram os materiais.
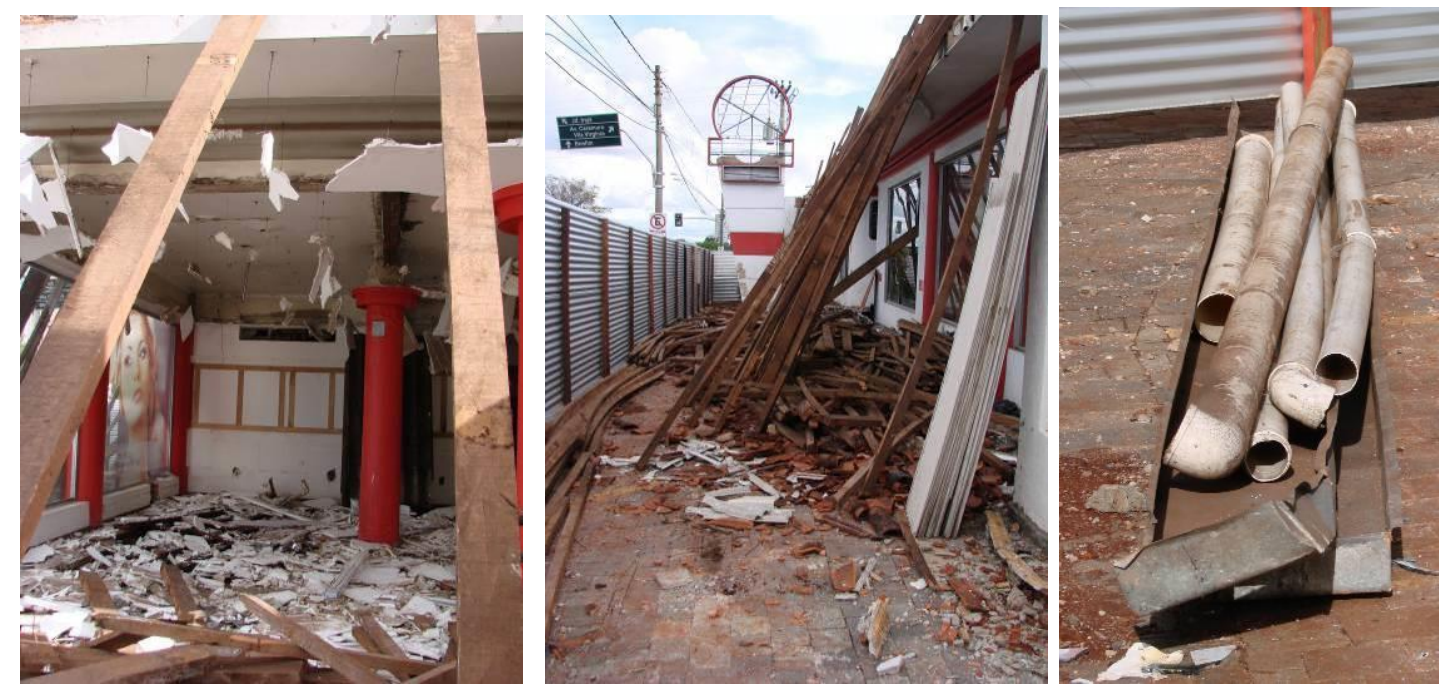

Figuras 6, 7 e 8 Imagens da demolição e separação de alguns materiais Fonte: Mattaraia (2012)

Posteriormente, a obra ficou fechada por uma semana, e no sábado pela manhã, foi demolida toda a estrutura e revestimento. Não houve separação de materiais. Os entulhos foram retirados simultaneamente à demolição, por um funcionário 
terceirizado, que segundo ele, iria depositar os resíduos próximos a um córrego para aterro da margem.
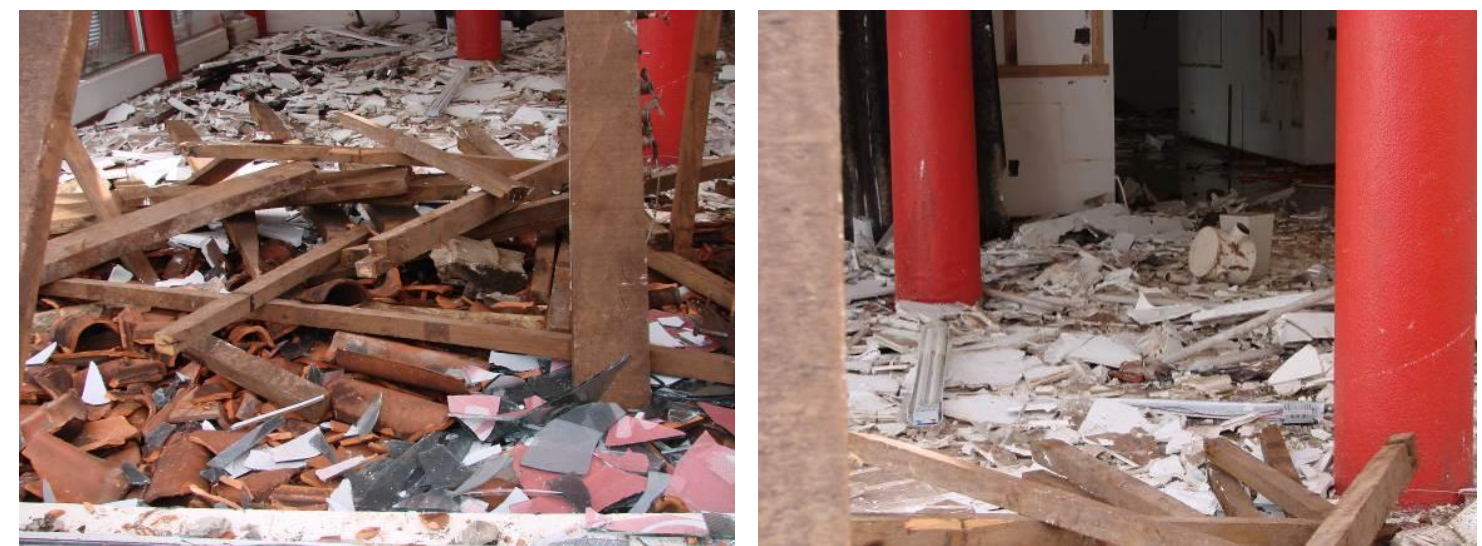

Figura 9 e Figura 10 Imagens de diversos materiais misturados na demolição Fonte: Mattaraia (2012)

Para a demolição foi utilizada uma máquina retro escavadeira, operada por um funcionário, também terceirizado. Na obra havia dois funcionários da demolidora, que organizavam os entulhos e retiravam os materiais que caiam nas calçadas ou vias.

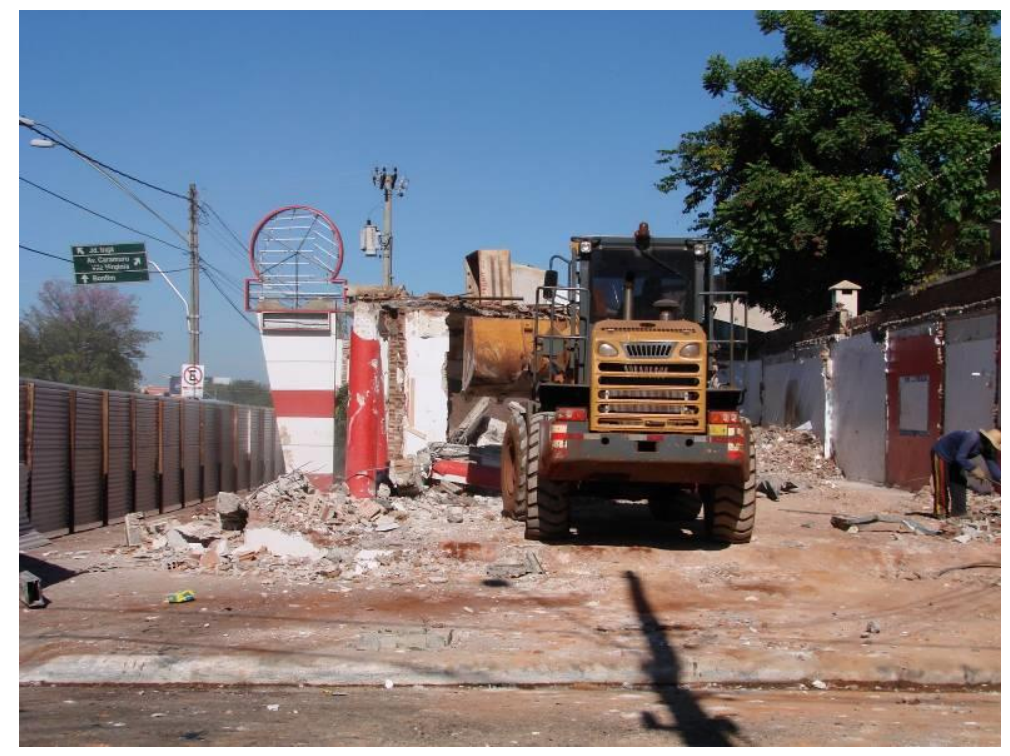

Figura 11 Máquina demolindo a estrutura Fonte: Mattaraia (2012)

Neste estudo foi possível perceber quais materiais puderam ser retirados sem comprometer gravemente sua qualidade, de maneira que possam ser reutilizados, e 
quais tiveram que ser demolidos pela máquina e acabaram sendo removidos apenas como entulhos.

Como a obra foi construída com muitas ligações químicas, não havia separação de sistemas e subsistemas no edifício, pois estavam interligados. Muitas vezes para retirar um material para revenda, como por exemplo, o vidro temperado, a alvenaria era quebrada. Isso danifica o material da alvenaria que fica inutilizado.

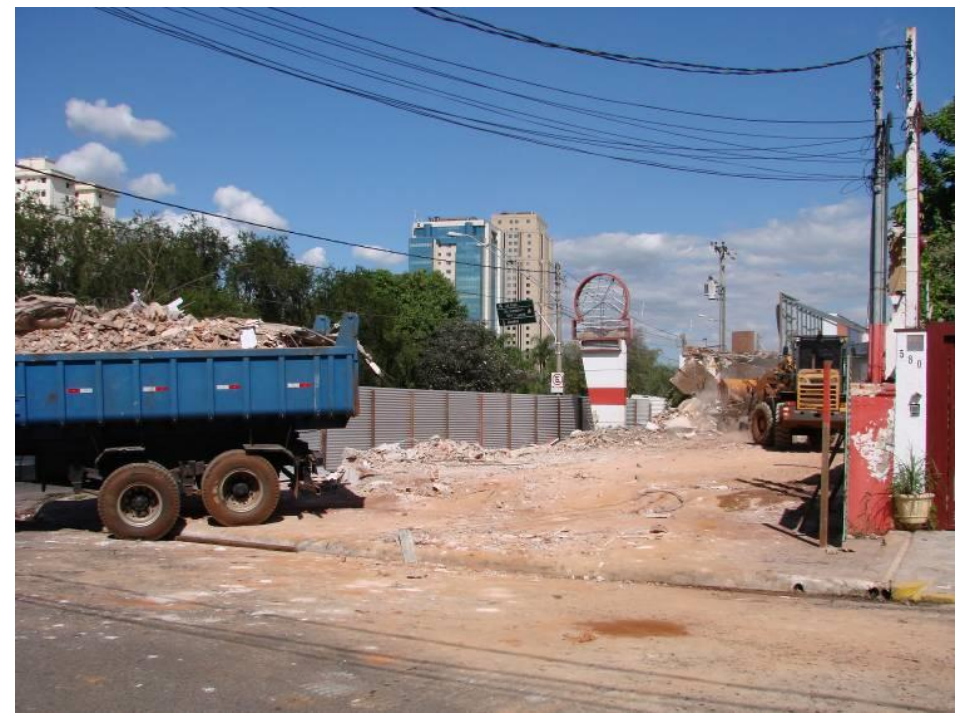

Figura 12 Finalizando a demolição

Fonte: Mattaraia (2012)

\subsection{Demolição Controlada}

Este tema foi abordado em uma reportagem de Corsini (2012) para a revista Téchne, onde fala sobre alguns casos em que foi utilizado este conceito devido à necessidade de desmontar as edificações, ou parte delas, de maneira mais controlada, com a intenção de reduzir a poeira, ruídos e evitar danificar outras partes do edifício ou do entorno. Normalmente é utilizado para obras de grande porte, onde não é possível a demolição total. 
Segundo (Corsini, 2012) "a demolição controlada é um procedimento de desmontagem de uma estrutura ou edificação". Para o autor, na demolição convencional o edifício é demolido, quase inteiramente, sem separar os materiais e componentes, enquanto que na demolição controlada é possível programar melhora a demolição e separar os elementos, além disso, traz algumas vantagens como: melhorar a reutilização de materiais, reduzir a emissão de poeira, ruído e ainda preserva melhor as estruturas desconstruídas. Esta foi umas das técnicas desenvolvidas para solucionar a questão da falta de planejamento do desmonte ou flexibilidade dos edifícios.

Foram citadas três empresas, uma delas aceitou fazer a entrevista (empresa A) e outra aceitou responder à um questionário (empresa B) desenvolvido pela pesquisadora com base em informações fornecidas pelo artigo e demais dados da revisão bibliográfica (ver anexos). As duas empresas utilizam a técnica de corte adiamantado como uma das principais para realizar o desmonte.

O engenheiro entrevistado pela autora do trabalho, apresentou o caso de uma eclusa de Tucuruí-PA, que seria necessário demolir apenas uma parede maciça de concreto, para que fosse possível ampliar a construção. A obra não permitia vibração e se fosse realizada a demolição, iria danificar a estrutura adjacente (comportas metálicas com pintura especial).

Assim foi realizado um estudo da melhor maneira de retirar a parede de concreto. Esta foi cortada em peças, com uma máquina de corte adiamantado. As peças pesavam entre 9 e 30 toneladas $^{13}$ e tiveram que ser içadas. Para isso foram necessários 6 operários e o processo levou 5 meses.

\footnotetext{
${ }^{13}$ Informação obtida através de entrevista com o engenheiro responsável da empresa
} 
Abaixo é a imagem da parede da eclusa que deveria ser retirada, para que fosse possível a ampliação da construção. No entanto a demolição por explosivos poderia danificar o restante da edificação, assim foi necessário buscar alternativas, como a Demolição Programada, feita com cortes na estrutura pela máquina de corte adiamantado.

Na figura 13, também mostram a equipe necessária para o trabalho. São operários especializados para realizar este serviço, muito deles trabalham a mais de 10 anos na empresa.

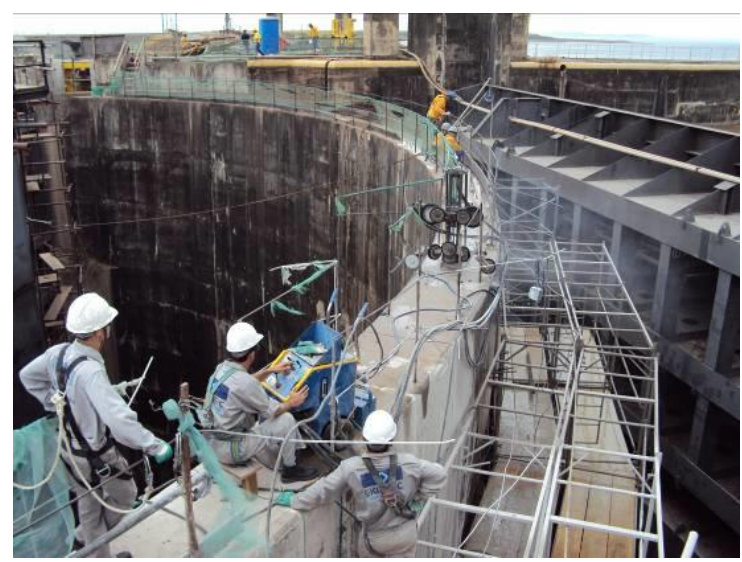

Figura 13 Montado o equipamento Fonte: Eng. Frederico del Villar (2009)

As figuras 14 e 15 mostra a montagem do equipamento para realizar os cortes.
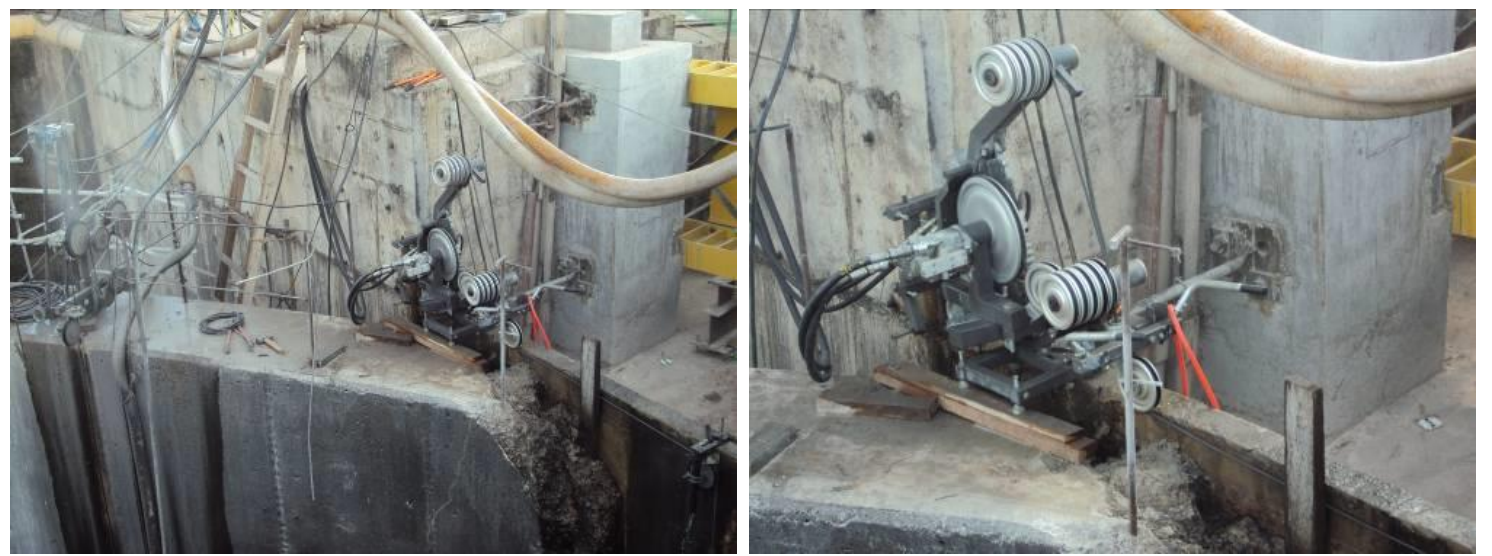

Figura 14 e 15 Máquina de Corte Adiamantado Fonte: engenheiro da empresa A (2009) 
Após cortadas, as peças precisam ser içadas, assim são colocados esses ganchos para que possam ser retiradas.
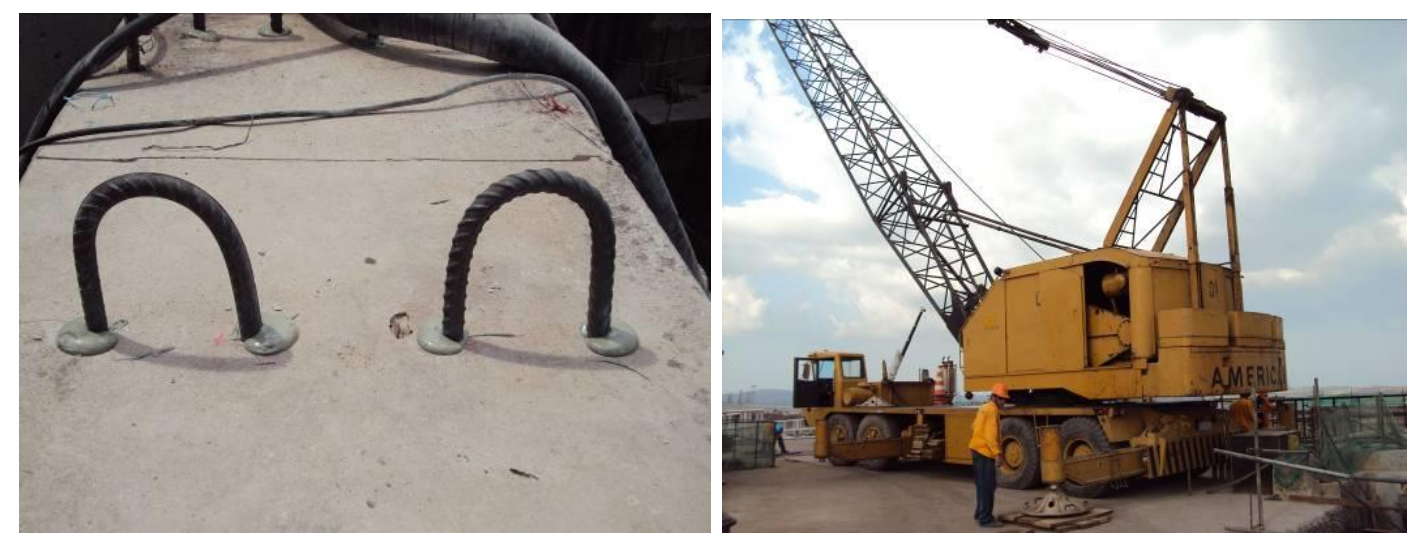

Figura 16 Gancho para içamento Figura 17 Máquina para içar Fonte: Eng. Frederico del Villar (2009)
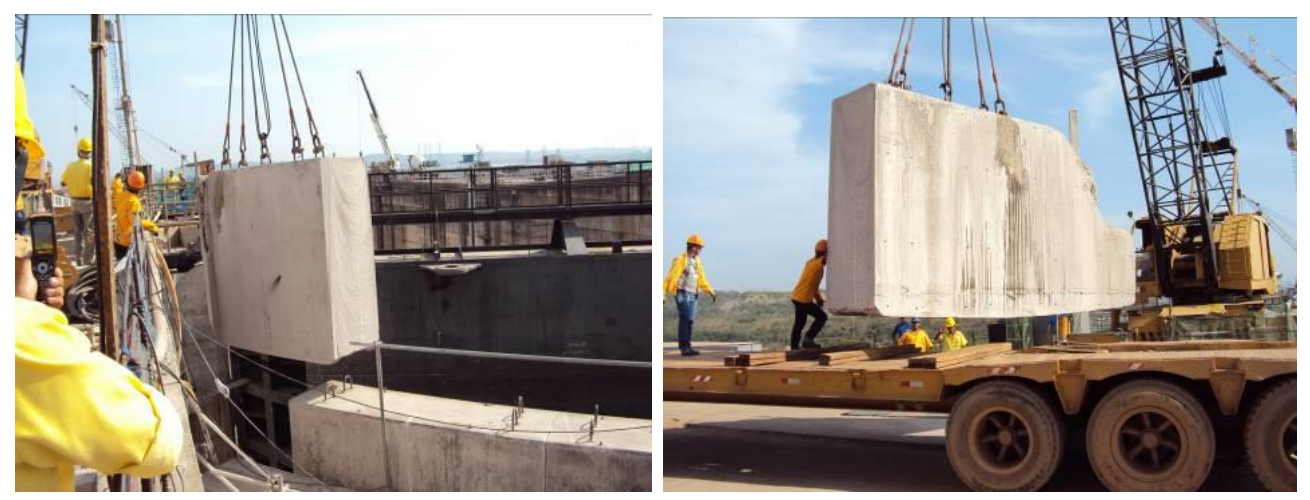

Figura 18 Peça de concreto sendo retirada Figura 19 Peça transportada Fonte: Eng. Frederico del Villar (2009)

Por fim, na figura 20 e 21 mostra algumas peças que foram retiras, sem danificar o restante da estrutura. Essas peças podem ser reutilizadas de alguma maneira, mas neste caso não foram.
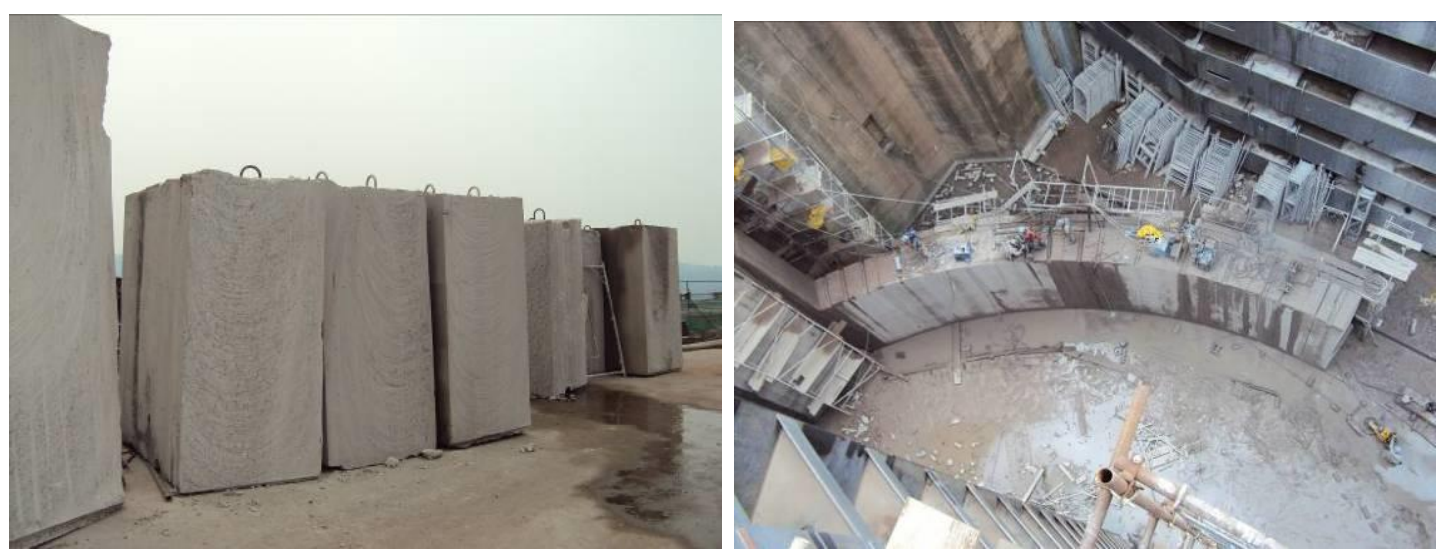

Figura 20 Peças de concreto removidas Figura 21 Finalizando o processo 
Fonte: Eng. Frederico del Villar (2009)

Neste estudo foi interessante observar a necessidade de desenvolver equipamentos e tecnologias, para desmontagem da construção, ou parte dela. No projeto havia previsão de ampliação da eclusa, no entanto, para que isso fosse possível, era necessário demolir esta parede e a maneira de realizar isto não constava no projeto.

\subsection{Construção com reutilização de materiais}

\subsubsection{Reutilização de estrutura de madeira}

Outro estudo realizado foi pesquisar a sede do clube de Golfe, da cidade de São Carlos-SP, com área de $1.300 \mathrm{~m}^{2}$, onde o principal conceito foi reutilizar estruturas de madeira de antigas tulhas de café de fazendas da região.

Foram realizadas entrevistas com o autor do projeto e o administrador do clube. Além de visitas ao local e análise do projeto. Neste estudo foram reutilizadas madeiras, tijolos e telhas. As madeiras foram usadas de diversas maneiras: como estrutura, caixilhos e até mesmo detalhes construtivos e decorativos. Grande parte do material pode ser reaproveitado, no entanto parte das telhas e tijolos retirados foi perdida.

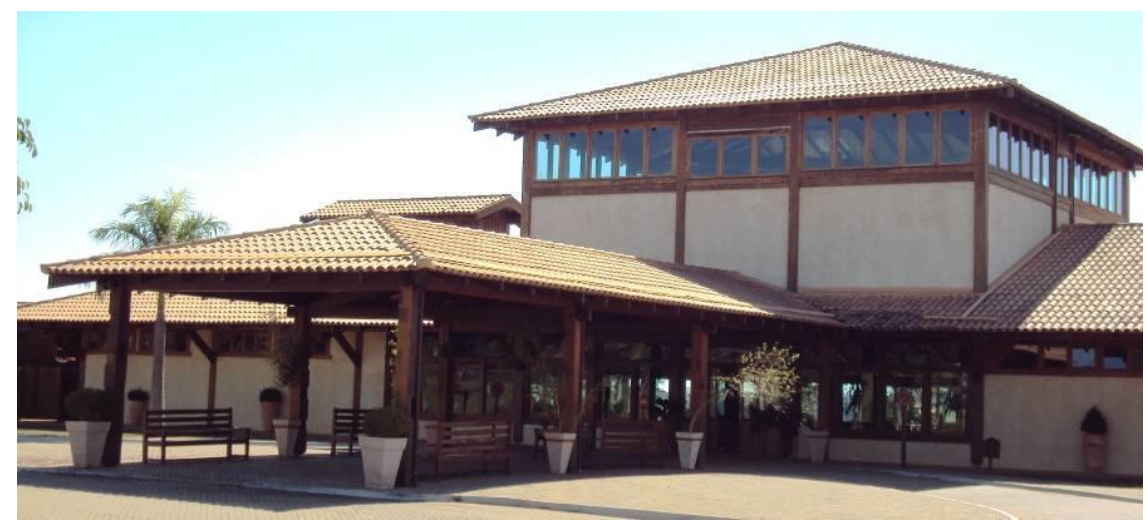

Figura 22 Fachada da sede do clube de Golfe Fonte: Mattaraia (2011) 
Logo no início do projeto o arquiteto teve a intenção de reutilizar materiais, posteriormente, os clientes falaram que tinham comprado madeiras de antigas tulhas que poderiam ser reaproveitadas. O projeto foi desenvolvido por cerca de um ano e a construção por pouco mais de um ano. Ao longo do desenvolvimento do projeto foram realizados detalhamentos e estudos em maquetes físicas e eletrônicas, com a intenção de obter o melhor aproveitamento dos materiais.

Segundo o administrador do clube, que também acompanhou a obra, as madeiras são provenientes de 5 tulhas de café da região. Os fazendeiros estavam demolindo, mas queriam aproveitar o material de alguma maneira, pois é um material nobre, peroba rosa, que atualmente é difícil de encontrar para comprar.

A madeira é um material que tem características que contribuíram muito com o processo, pois foi possível utilizar na estrutura, caixilhos, mobiliário. Além disso, é considerado um material sustentável. Para Molina e Calil Jr (2010) a madeira apresenta várias vantagens, pois é um material renovável, consome carbono durante o crescimento das árvores, tem fácil trabalhabilidade, tem bom desempenho térmico e acústico, ótima relação resistência / peso, facilidade no transporte, na montagem e desmontagem do edifício.

As figuras 23 e 24 mostram a montagem da estrutura com as peças reutilizadas. Algumas peças tiveram que ser compradas para complementar a estrutura, mas grande parte foi reutilizada. 

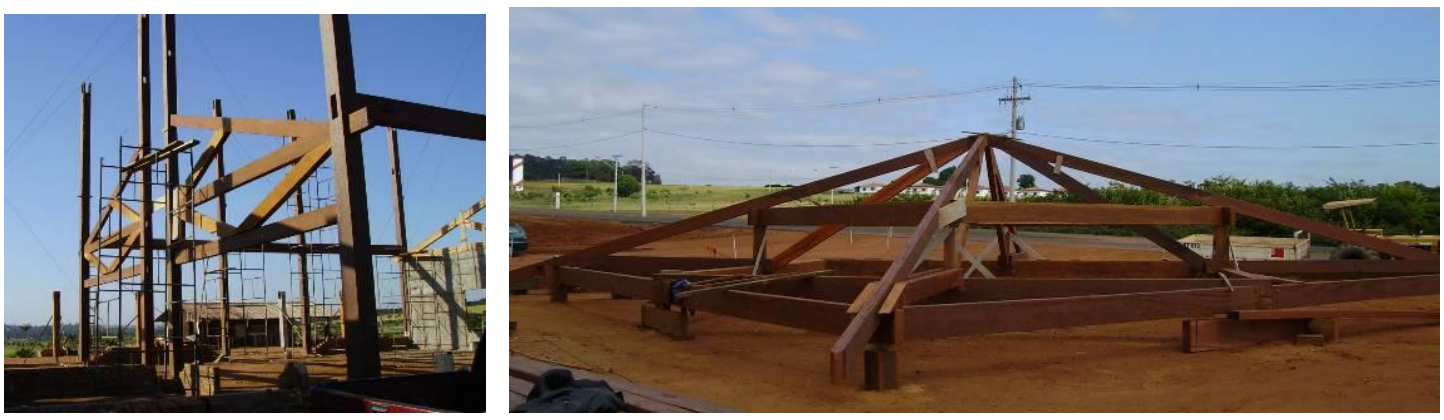

Figura 23 e Figura 24 Montagem da estrutura

Fonte: Arq. José Mário Nogueira (2007)

As peças de madeira puderam ser aproveitadas de diversas maneiras, até mesmo para fazer móveis e peças de decorações, como nas figuras 25 e 26.
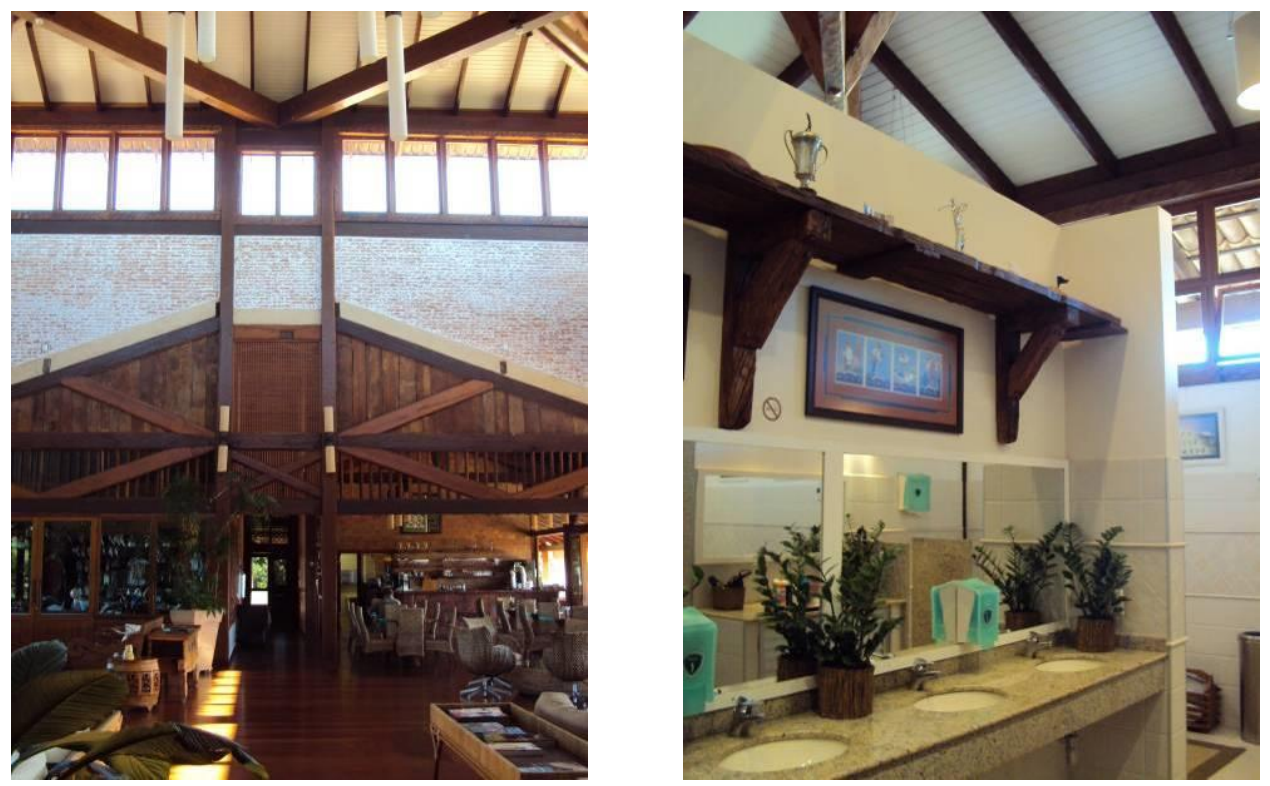

Figura 25 e 26 Saguão do Clube e banheiro, ambientes onde há madeiras reutilizadas na estrutura, detalhes e mobiliários.

Fonte: Mattaraia (2011)

Os tijolos que aparecem na figura acima também são reaproveitados das antigas tulhas. Por serem maciços e terem sido assentados com barro anteriormente, foi possível ter um grande porcentual de reaproveitamento.

Também na figura acima há dois pilares centrais de $13 \mathrm{~m}$ de altura que foram reutilizados. No caso destas peças, por serem muito grandes, foi necessário maior cuidado na desmontagem, transporte e montagem para que fosse possível aproveitar a 
peça. O fato de serem grandes e pesadas dificultou o processo, mas mesmo assim, foi possível.

Também foi reaproveitada grande parte das telhas cerâmicas. Por serem peças pequenas e encaixadas, facilitou a desmontagem e o transporte. No entanto são peças frágeis e muitas se quebraram durante a desmontagem do telhado original ou no transporte. Assim não foi possível aproveitar todas as peças.

Nas figuras 27, 28 e 29 é possível entender melhor o projeto.

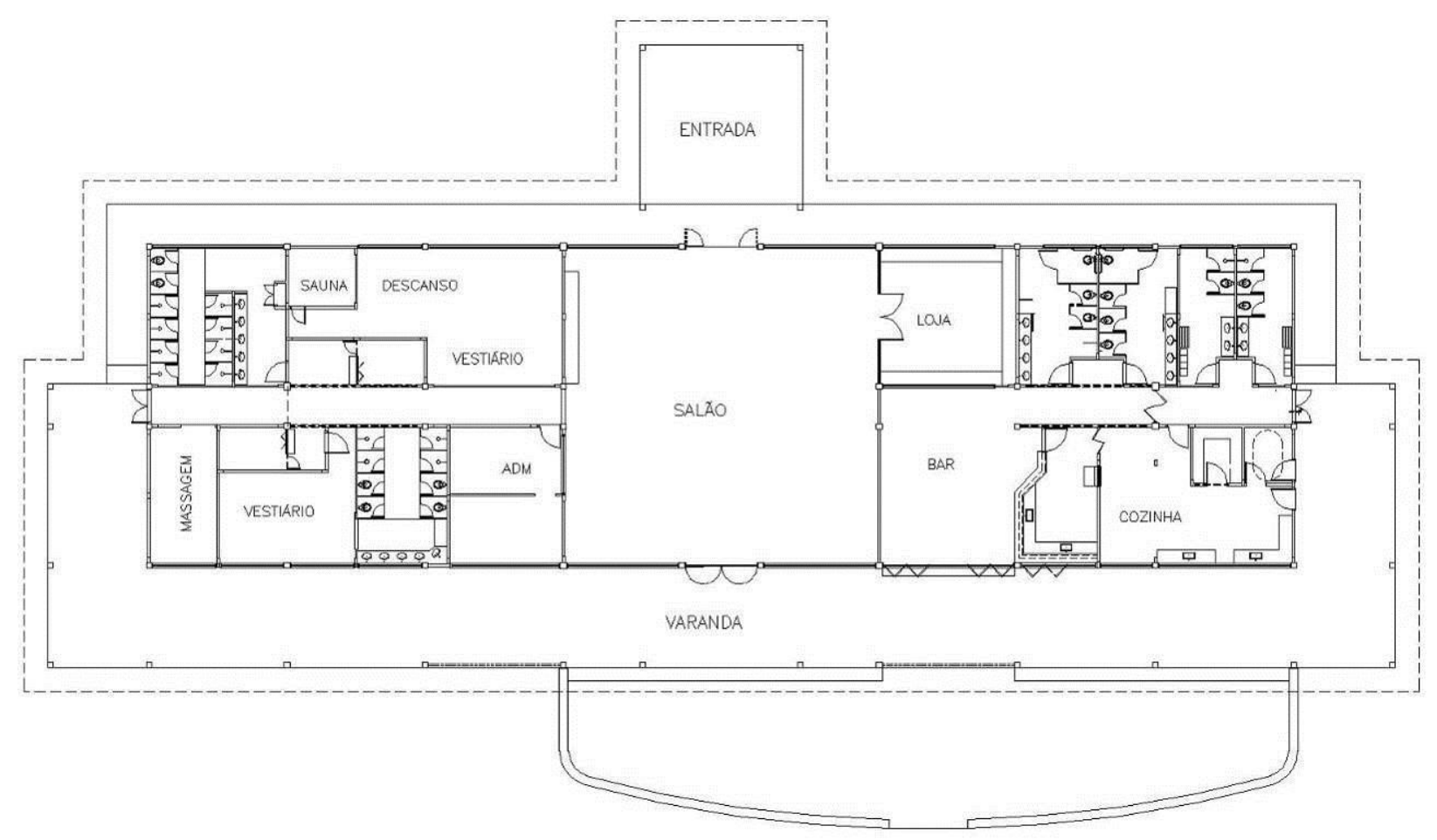

Figura 27 Planta Baixa (sem escala)

Fonte: Arq.José Mário Nogueira (2006)

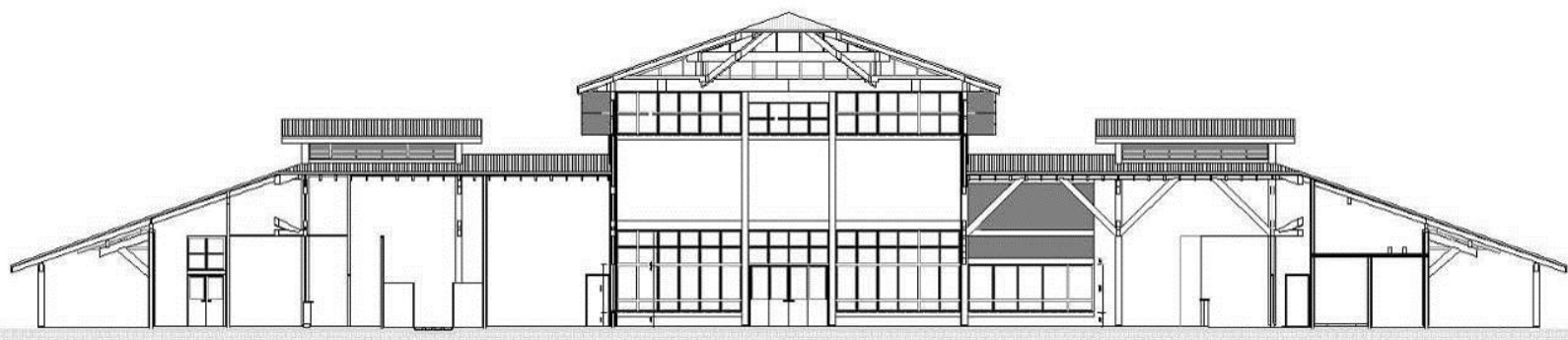

Figura 28 Corte Longitudinal (sem escala) 


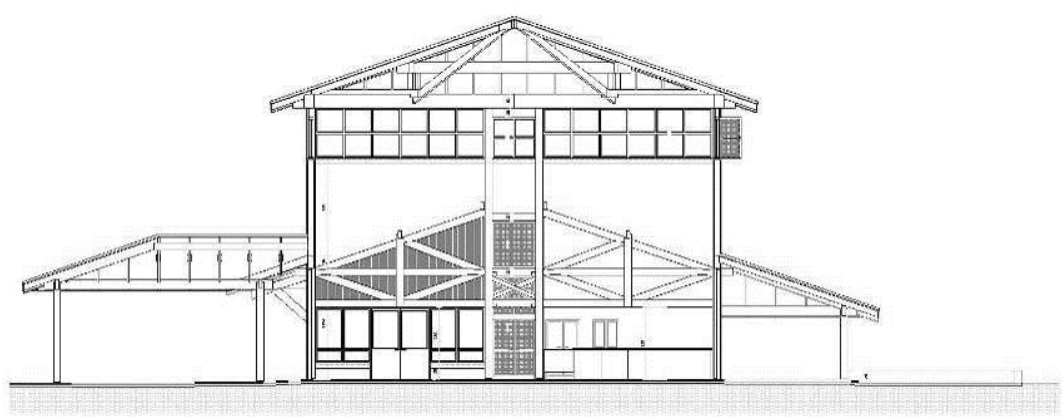

Figura 29 Corte Transversal (sem escala) Fonte: Arq.José Mário Nogueira (2006)

Na planta, figura 27, é possível para ver a disposições dos ambientes e perceber a dimensão da construção. A sede do clube é composta por um salão, bar, cozinha, varanda, vestiários e escritório. Nos cortes, acima, é possível perceber alguns detalhes estruturais das peças de madeira.

As figuras 30 e 31 demonstram as peças estruturais de madeira reutilizadas, fica claro algumas marcas de antigos encaixes, que facilitaram o desmonte, sem danificar tanto a peça, e permitiu que a peça fosse reutilizada.
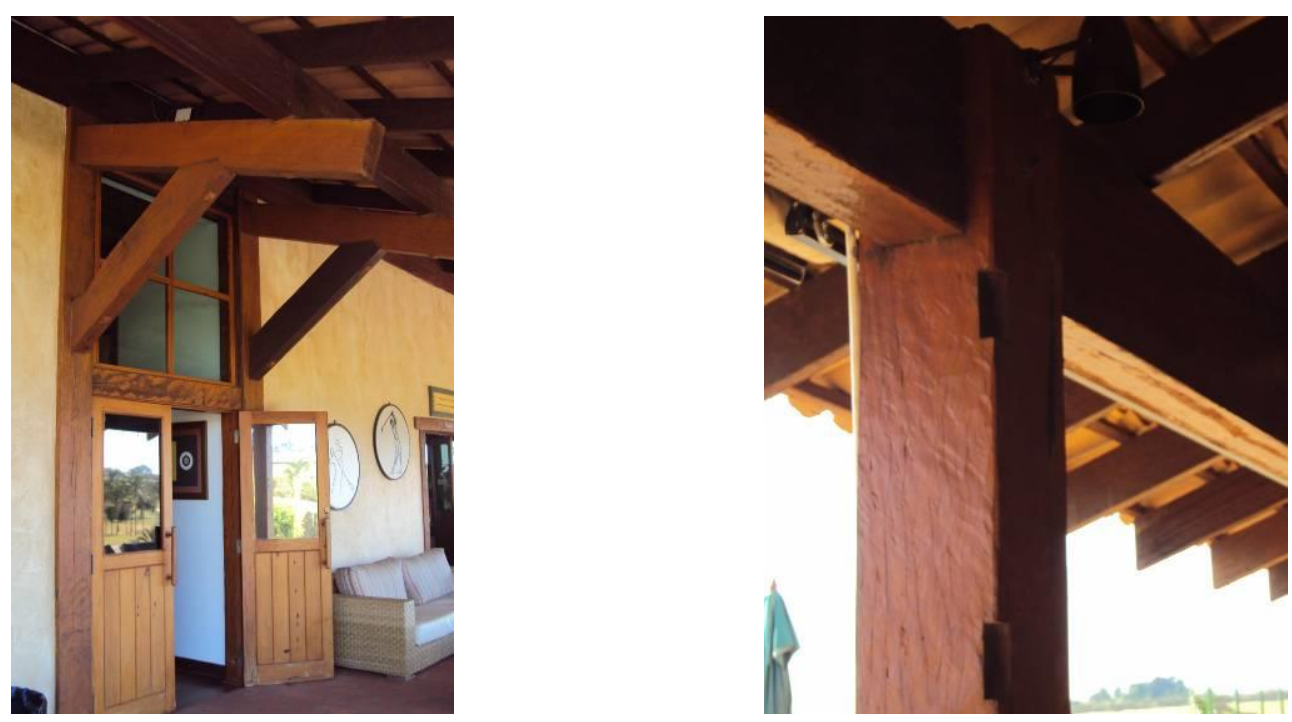

Figura 30 e Figura 31 Detalhes da estrutura de madeira reutilizada Fonte: Mattaraia (2011) 
Desde o início do projeto o arquiteto teve a intenção de deixar aparente as marcas que o material adquiriu na antiga construção. Em nenhum momento houve a preocupação de escondê-las para ficar parecido com uma peça nova que nunca foi utilizada. Isso foi muito significante, pois criou uma estética interessante que foi muito bem aceita pelos clientes e usuários.

Outras marcas como desgaste e pregos também não foram escondidas, muitas peças com estes sinais foram colocadas até mesmo na entrada principal do clube, pois não impediam que cumprisse sua função principal, de serem peças estruturais. Como demonstram as figuras 32, 33 e 34. A construção já tem 5 anos e os materiais não apresentaram nenhum problema, nenhuma peça teve que ser trocada.
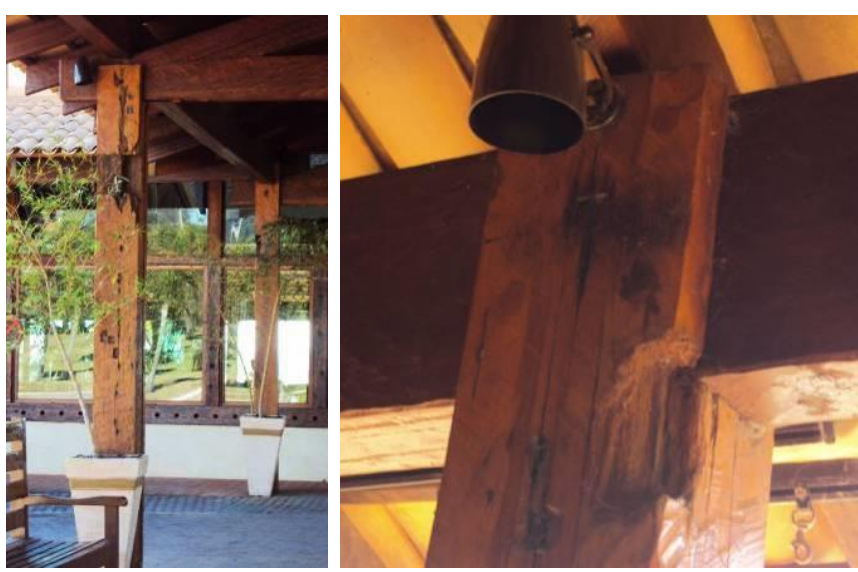

Figuras 32, 33 e 34 Peças de madeira reaproveitadas com marcas dos antigos encaixes fonte: Mattaraia (2011)

$\mathrm{O}$ arquiteto afirma que o processo de projeto não foi muito diferente da rotina do escritório, pois cada projeto tem seu desafio, além disso, reutilizou diversos materiais em outras obras. O projeto contou com a colaboração de diversos profissionais: um calculista estrutural, um engenheiro especializado em construção de madeira, um profissional especializado na área de conforto ambiental e a equipe do escritório. Também foram realizadas maquetes física e eletrônica que contribuíram para resolver detalhes técnicos. 


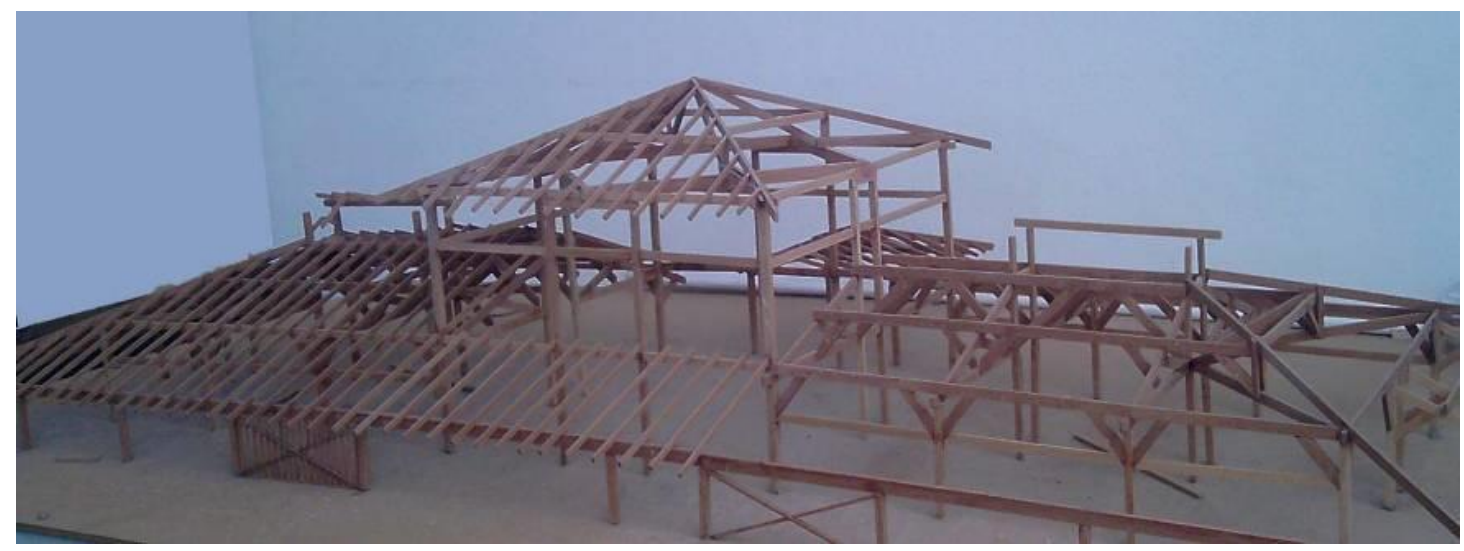

Figura 35 Maquete física desenvolvida pelo escritório de arquitetura fonte: Arq. José Mário Nogueira (2006)

Este estudo de caso foi muito importante para verificar quais características dos materiais podem facilitar ou dificultar o reaproveitamento de materiais, quando na construção original não foi considerado o processo de desmonte, após a vida útil do edifício.

Os materiais utilizados originalmente nas tulhas de café ainda se encontravam em boas condições, no entanto, as tulhas não eram mais necessárias. Assim foi possível perceber que é possível reaproveitar parte dos materiais, mesmo sem que houvesse uma preocupação com o desmonte, na construção das tulhas. Porém, fica claro que se existisse esta preocupação, seria possível obter resultados ainda melhores. Além disso, este estudo demonstra que materiais reutilizados podem cumprir suas funções com qualidade e contribuem, até mesmo, com a estética.

\subsubsection{Reutilização de estrutura metálica}

Outra obra estudada em que foi houve reutilização de materiais foi o ginásio de esportes da USP - São Carlos, com área de $2.111 \mathrm{~m}^{2}$, onde a estrutura metálica da cobertura foi reaproveitada da construção de um hangar. O Estudo a ser apresentado 
é a construção da Quadra poliesportiva do campus da USP de São Carlos. Foi construído em 1999 e desenvolvido pela prefeitura do campus.

O projeto reutilizou a cobertura de estrutura metálica de um antigo hangar. Toda a estrutura pode ser reaproveitada. Ela foi remontada com o mesmo uso, como cobertura e não houve perdas. As peças foram numeradas e houve cuidado no desmonte e montagem para que não houvesse perdas. O reaproveitamento da estrutura viabilizou economicamente a construção

Inicialmente, o Hangar, no Broa em São Carlos, serviria para um curso de aviação, mas o curso não chegou a ser implantado e a estrutura não foi utilizada. Com o passar do tempo a estrutura estava sendo desgastada pela ação do tempo, do ambiente e falta de manutenção.

A estrutura da cobertura do ginásio foi montada rapidamente, quando comparada a outros métodos, em aproximadamente 2 semanas. A reutilização da cobertura metálica contribui para que o processo fosse rápido. Para receber esta cobertura, foram construídas a fundação, pilares em concreto armado e paredes em alvenaria, que levou alguns meses.

A sequência de figuras abaixo mostra como era o hangar, o processo de desmontagem e montagem da cobertura. Nas figuras 36 a 39, é possível ver o antigo hangar, que nunca foi utilizado, em estado de depreciação.
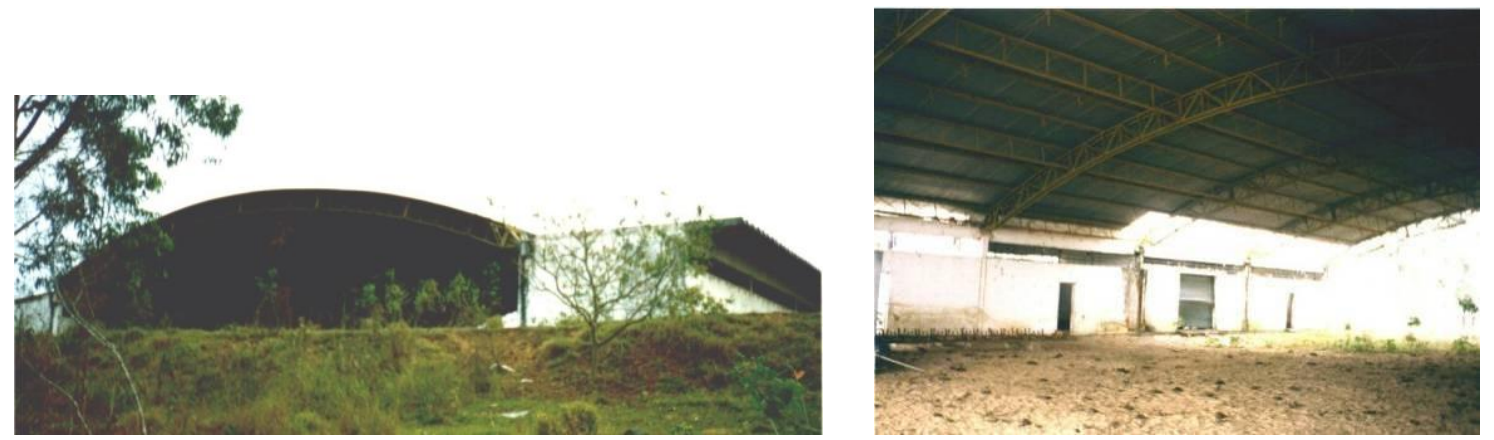
Figura 36 e 37 Antigo Hangar

Fonte: prefeitura da USP-SC (1998)
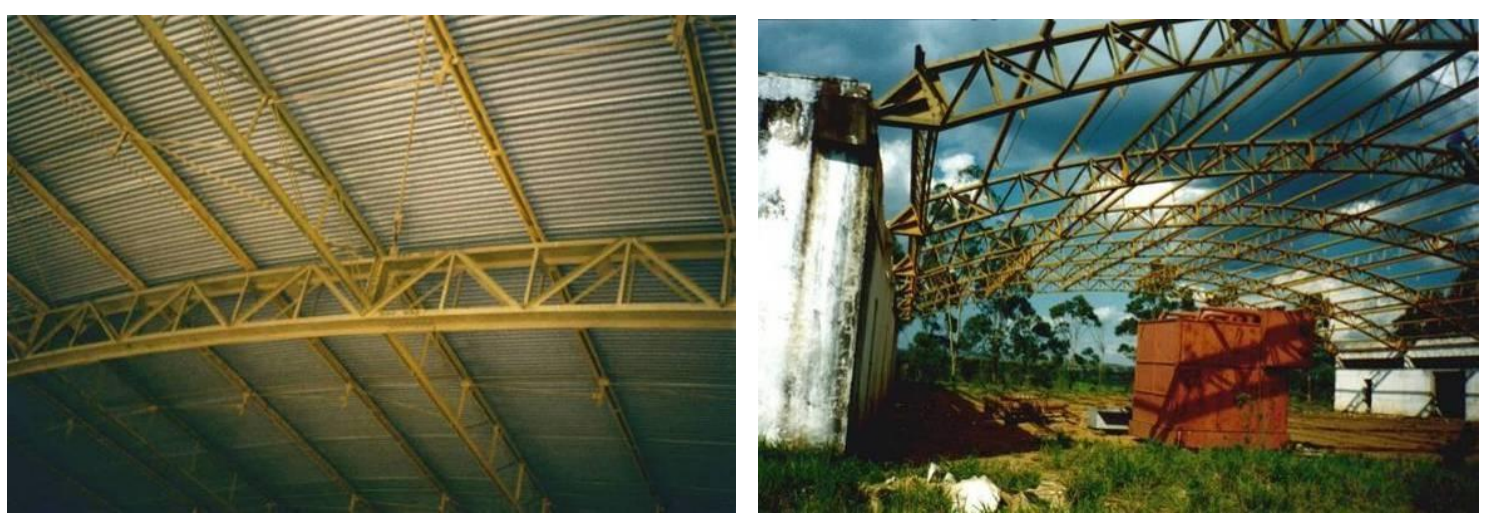

Figura 38 e 39 Cobertura do Hangar Fonte: prefeitura da USP-SC (1998)

As imagens 40 e 41 demonstram o desmonte da cobertura metálica do hangar.
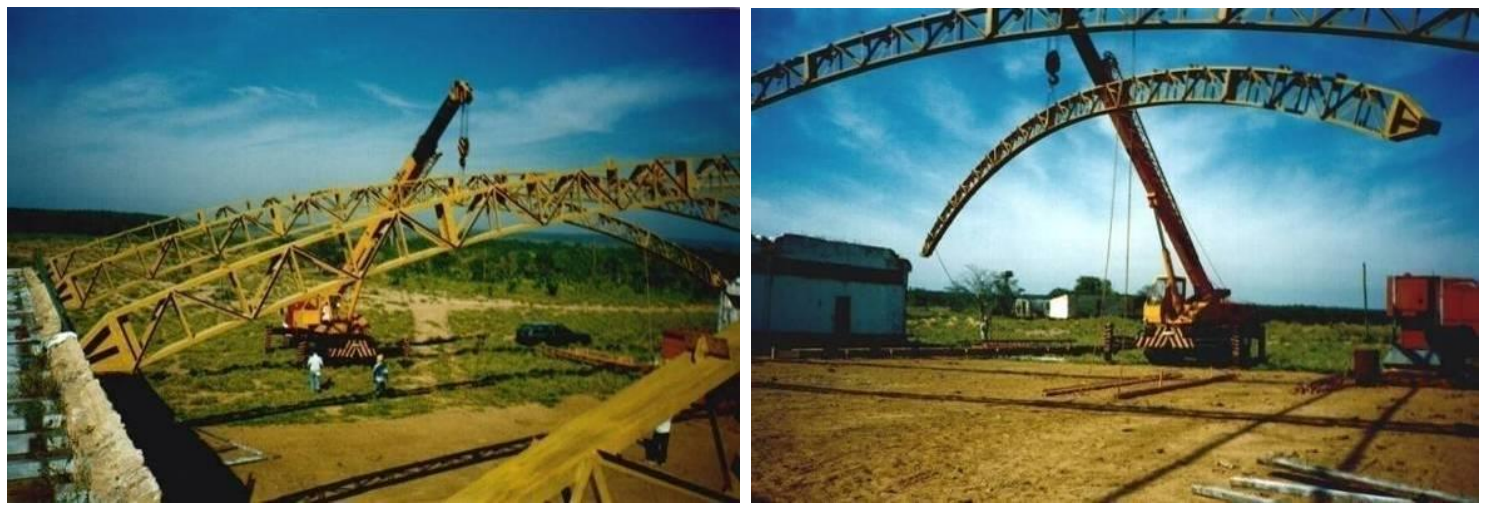

Figura 40 e 41 Desmonte da Cobertura Fonte: prefeitura da USP-SC (1999)

Nas figuras 42 e 43 são as peças da cobertura desmontadas e numeradas para facilitar a montagem do ginásio. 


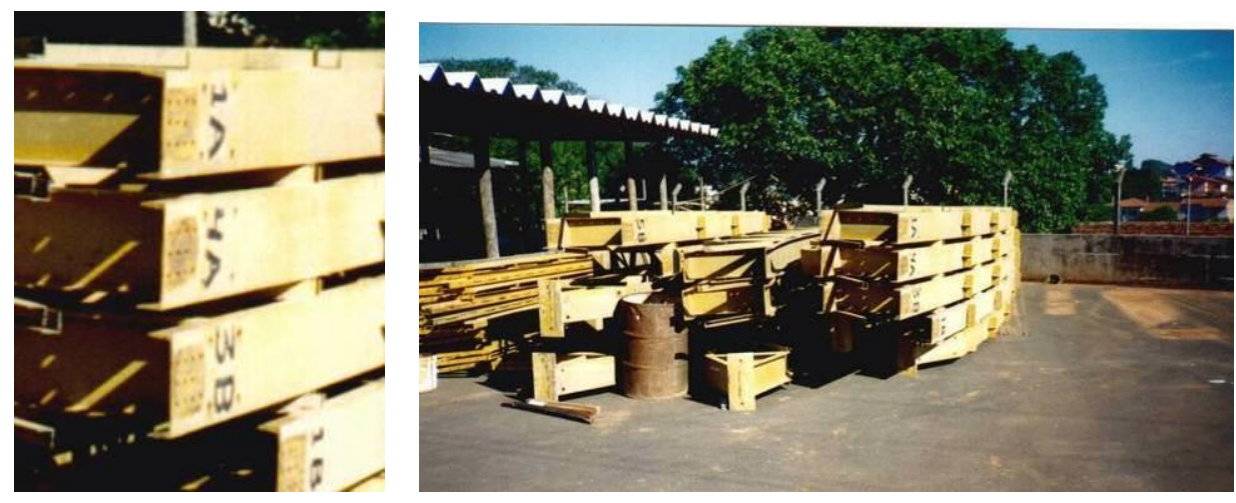

Figura 42 e 43 Peças metálicas da cobertura Fonte: prefeitura da USP-SC (1999)

Nas próximas figuras, é o início da construção do ginásio, sua fundação e base feita em concreto, para receber a cobertura metálica do hangar.
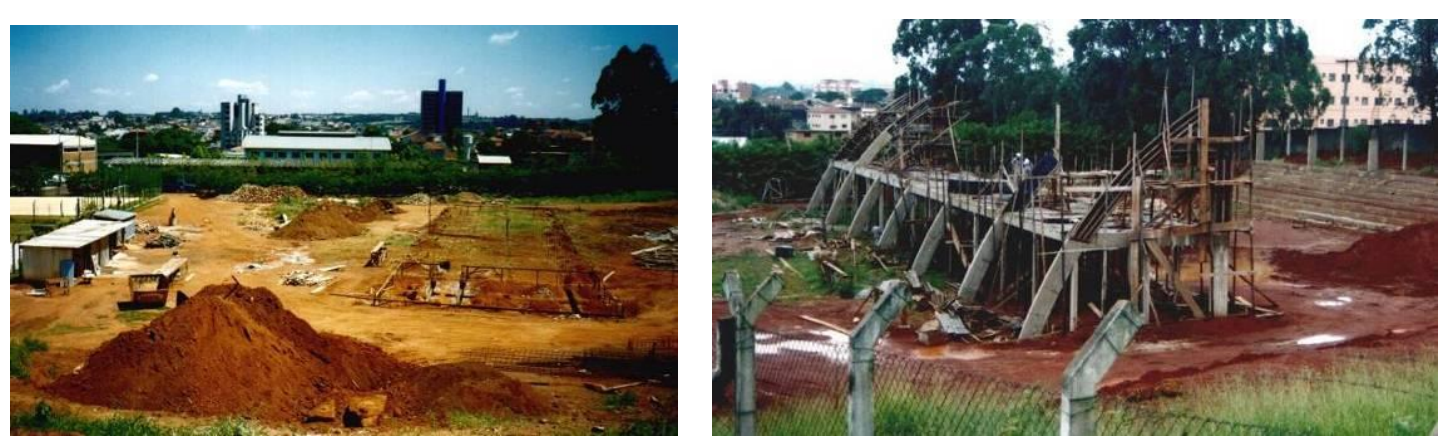

Figura 44 e 45 Construção do ginásio

Fonte: prefeitura da USP-SC (1999)

Nas figuras a seguir, mostram a montagem da estrutura que encaixam na estrutura de concreto que foi projetada para receber esta cobertura.
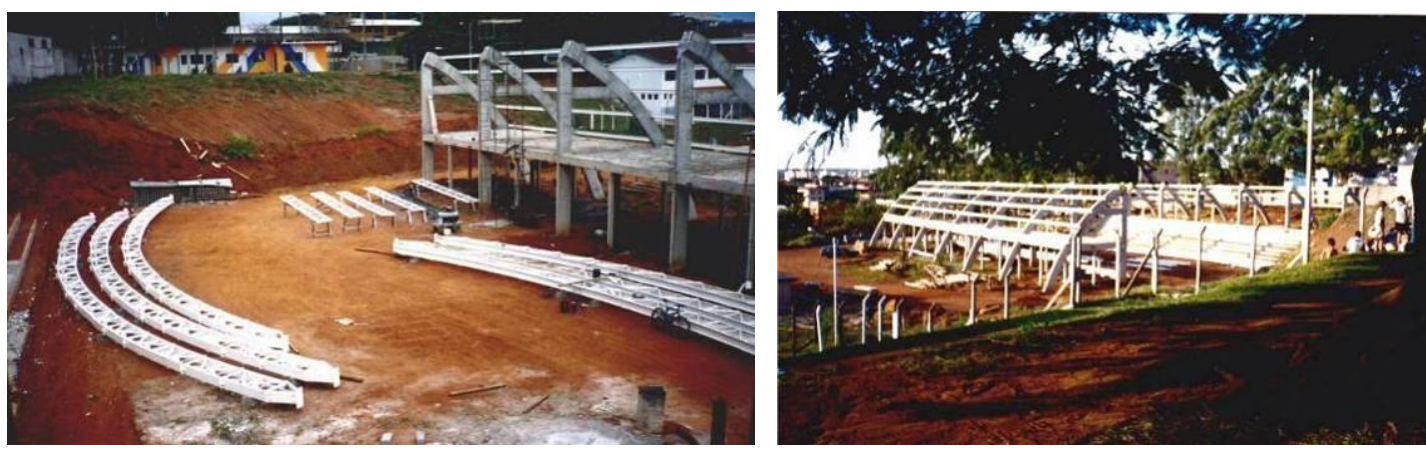

Figura 46 e 47 Construção do ginásio Fonte: prefeitura da USP-SC (1999) 

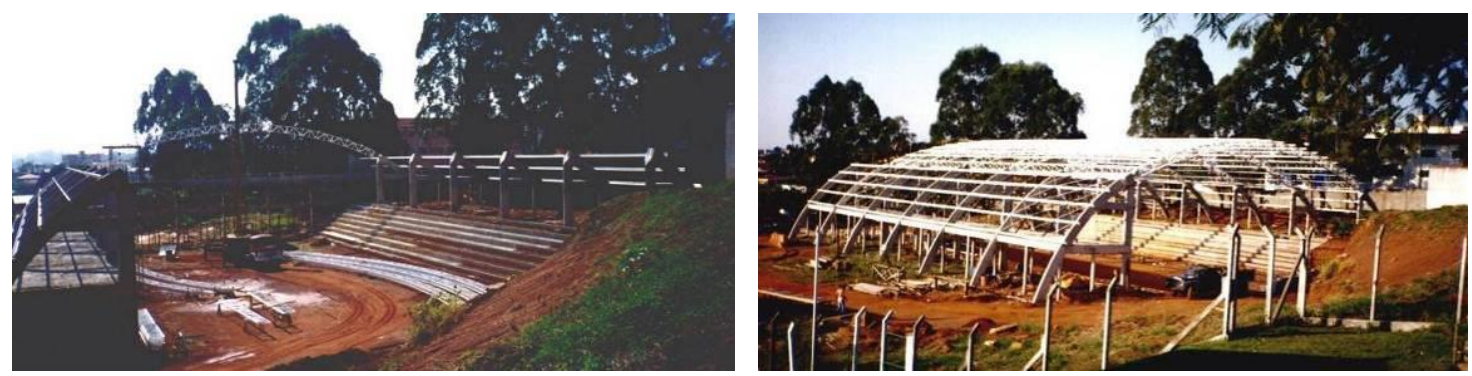

Figura 48 e 49 Montagem da cobertura do ginásio Fonte: prefeitura da USP-SC (1999)

Nas figuras abaixo, a colocação das telhas e finalizando a obra.
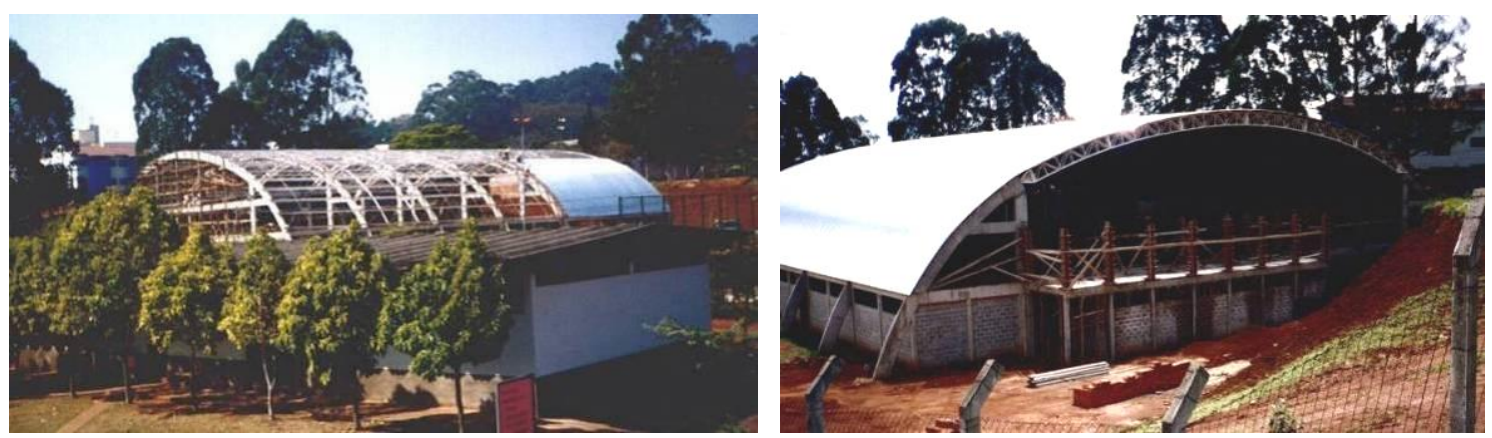

Figura 50 e 51 Construção do ginásio Fonte: prefeitura da USP-SC (1999)

Na figura 52 é o ginásio pronto.

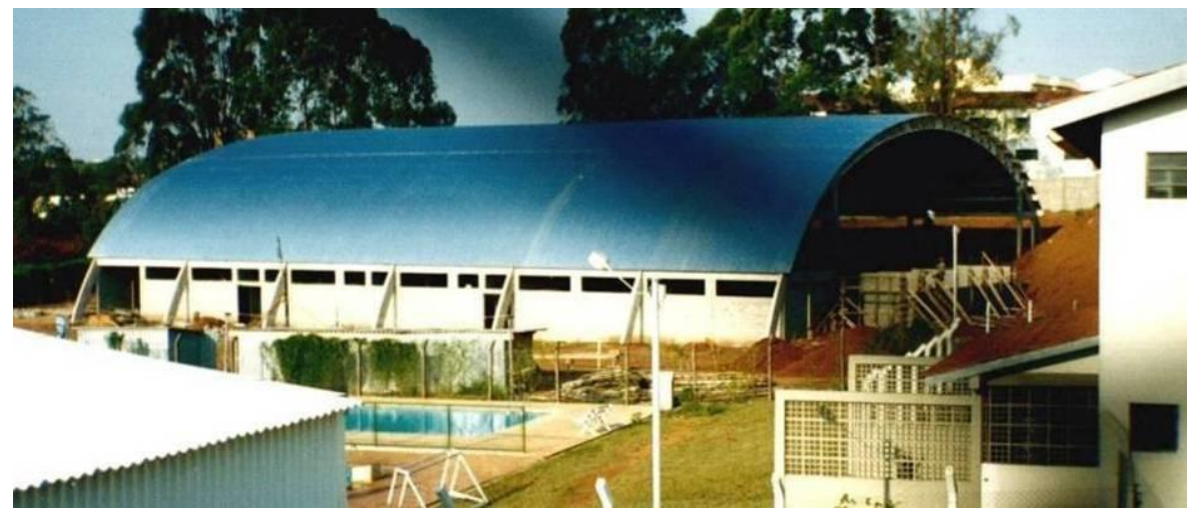

Figura 52 Ginásio Pronto

Fonte: prefeitura da USP-SC (1999)

Nas figuras 53 e 54 são apresentadas as plantas, para melhor compreensão do projeto. O projeto foi desenvolvido com a intenção de reaproveitar a estrutura do antigo hangar, assim as plantas e a estrutura foram projetadas para que recebesse 
esta estrutura. No entanto foi necessário seguir as exigências do programa de necessidades, para que fossem cumpridas as necessidades funcionais do edifício. Tanto as necessidades funcionais como o conceito de reaproveitar a estrutura, devem ser consideradas no desenvolvimento do projeto. Assim é possível obter melhores resultados.

Assim, seguem as plantas do ginásio para melhor compreensão do projeto.

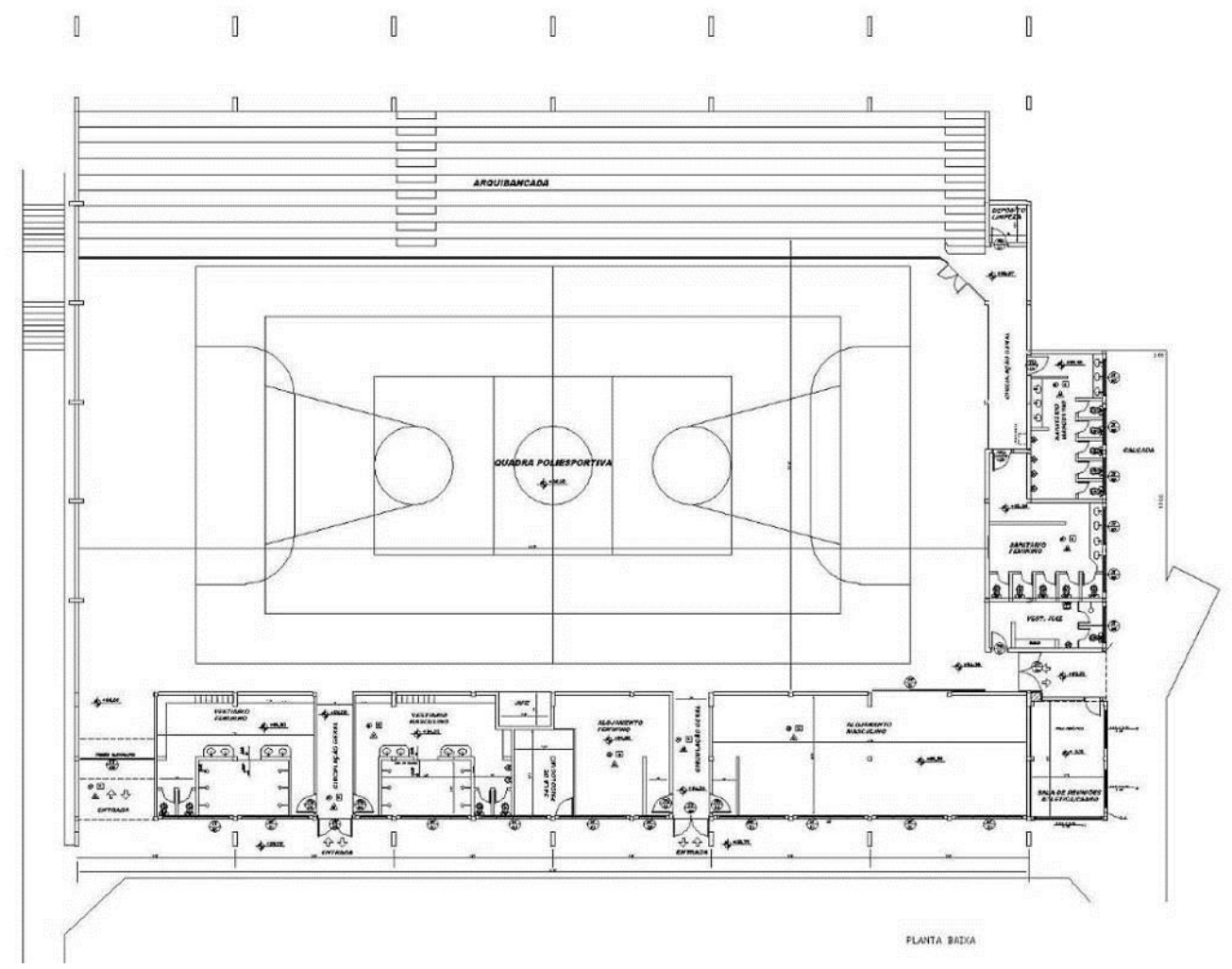

Figura 53 Planta do ginásio (sem escala) Fonte: prefeitura da USP-SC 


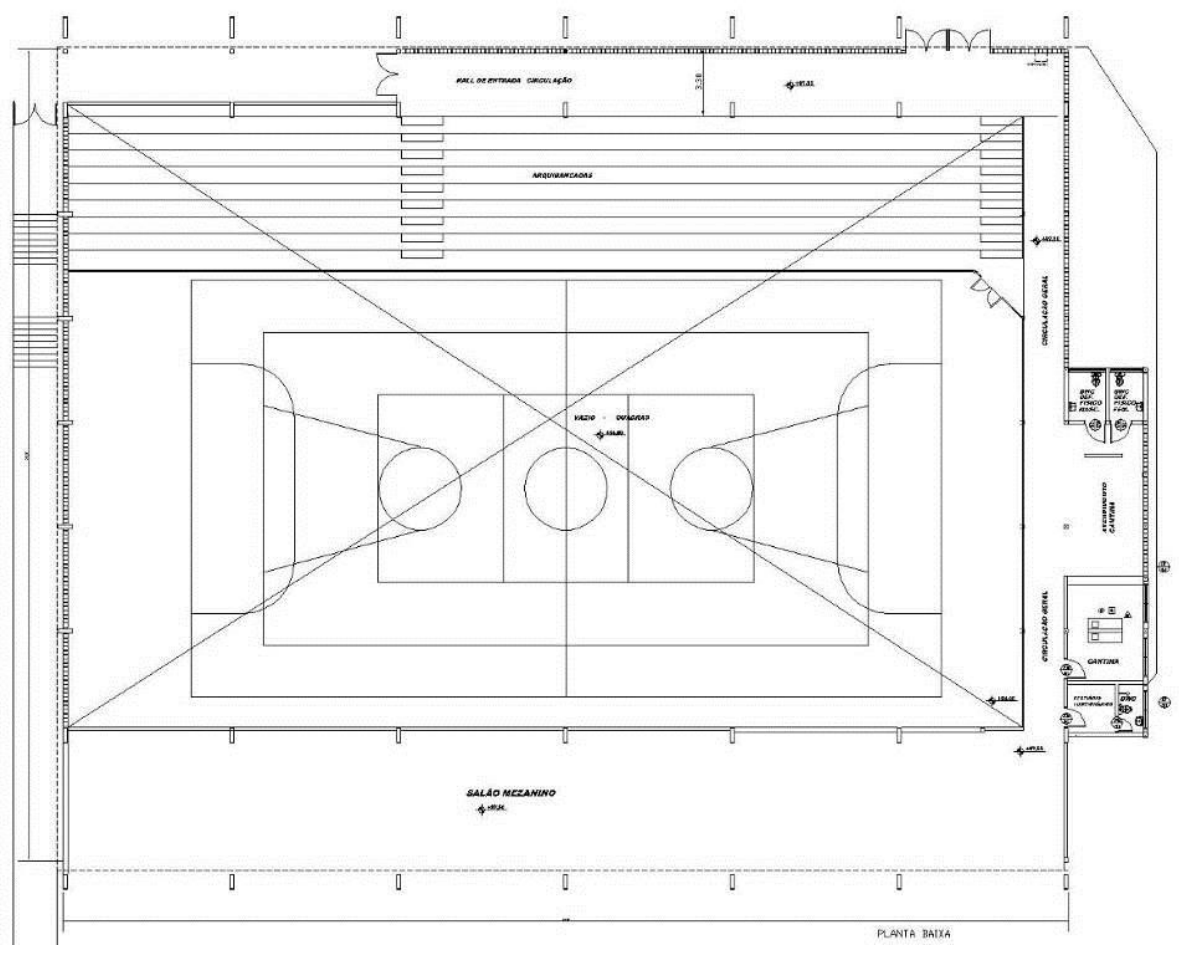

Figura 54 Planta do Ginásio (sem escala) Fonte: prefeitura da USP-SC

Os arquitetos envolvidos estão acostumados a inserir elementos reaproveitados de outras construções nos projetos, assim o processo de desenvolvimento não muda muito a rotina de trabalho da equipe. O primeiro passo foi verificar a estrutura disponível e as dimensões das peças, para desenvolver um projeto que condiz com o material disponível.

As estruturas metálicas têm grandes vantagens neste processo, principalmente, se forem aparafusadas, como no caso apresentado. O sistema permite ser desmontado sem que danifique as peças. Além disso, o material pode ser reciclado inúmeras vezes, caso seja necessário.

As estruturas em aço têm algumas características que podem contribuir com o desenvolvimento sustentável. São flexíveis, permitem modulações, são industrializadas, permitem encaixes que podem ser desfeitos (no caso de parafusos), o material pode ser reaproveitado ou reciclado sem causar alterações nas suas características originais, 
gera baixa quantidade de resíduos na obra quando comparado ao sistema tradicional. Além disso, a obra é mais rápida do que o sistema tradicional, alta durabilidade e possui alta resistência. Todas estas características também contribuem para o processo de desmontagem.

Outra característica que torna interessante o estudo com este material é que o Brasil é um grande produtor em aço. Em 2010, a produção no Brasil de aço bruto, chegou a 32,8 milhões de tonelada, isso nos coloca na $9^{\circ}$ do ranking mundial, e o setor faturou R\$ 64 bilhões e exportou US\$ 5,8 bilhões (ABREU, 2011). Segundo o Instituto de Aço do Brasil (2010) o Brasil tem capacidade instalada para fabricar mais de 40 milhões de toneladas de aço por ano, no total são 13 empresas administradas por 8 grupos.

Porém, é importante ressaltar que esses números não são apenas para o setor da construção civil, no entanto, a construção civil, o setor automotivo, bens de capital, utilidades domésticas e comerciais representam $85 \%$ das vendas (INSTITUO DE AÇO DO BRASIL, 2012).

Neste estudo foi interessante analisar as possibilidades de reutilização permitidas por este sistema estrutural. A cobertura do hangar em estrutura metálica e aparafusada permitiu que toda a estrutura fosse desmontada e reutilizada na nova construção, com um novo uso. Neste caso não houve perdas, pois todas as peças puderam ser reaproveitadas. As peças foram numeradas, desmontadas e depois remontadas. A estrutura foi montada em apenas duas semanas

Além disso, houve grande economia financeira, o que viabilizou a construção do atual ginásio. Também houve ganhos ambientais, pois não foi necessário produzir mais peças metálicas o que consome recursos naturais não renováveis e polui o meio ambiente. 
Nestes dois casos (clube de golfe e ginásio) foi possível analisar como diferentes materiais puderam ser reutilizados e os resultados obtidos. Madeiras, estrutura metálica, telhas e tijolos puderam ser reutilizados de diversas maneiras, em alguns casos houve mais perdas e em outros foi possível reaproveitar todo o material. A maneira com que eles foram ligados e utilizados influenciou significadamente no resultado.

\subsection{Desmontagem (Eko House)}

Outro estudo de caso realizado foi a construção da Eko house. Este é um projeto que foi desenvolvido por uma equipe de pesquisadores de diversas áreas e construído no campus da USP - SP. O protótipo de uma residência foi projetado envolvendo diversos conceitos sustentáveis, com o objetivo de participar do concurso Solar Decathlon, realizado na Espanha, que envolve diversas universidades de vários países.

Este projeto foi escolhido para análise desta pesquisa, pois além dos conceitos sustentáveis incorporados, há uma condição do concurso em que o protótipo deve ser construído, depois desmontado e remontado no local da competição. Assim foi possível analisar como foram projetados os encaixes das estruturas, materiais e sistemas e as possibilidades de desmonte.

Foram realizadas entrevistas com uma das professoras envolvidas, além de alguns alunos e funcionários. Além disso, foram acompanhadas duas etapas, parte da construção e a desmontagem do protótipo.

O desenvolvimento do projeto durou cerca de um ano, pois havia várias características distintas de um projeto convencional. O projeto foi desenvolvido por equipes de alunos e professores de diversas áreas (arquitetura, engenharia civil, automação, elétrica e 
hidráulica). Além de atender a diversos requisitos sobre sustentabilidade e consumo de energia, também era essencial pensar na construção e na desmontagem, para que fosse remontado no Espanha (local do concurso).

A figura 55 é uma vista geral do protótipo durante a construção. Esta fase corresponde a etapa da execução das instalações elétricas e hidráulicas, além da colocação dos painéis modulares de compensado de madeira para vedação.

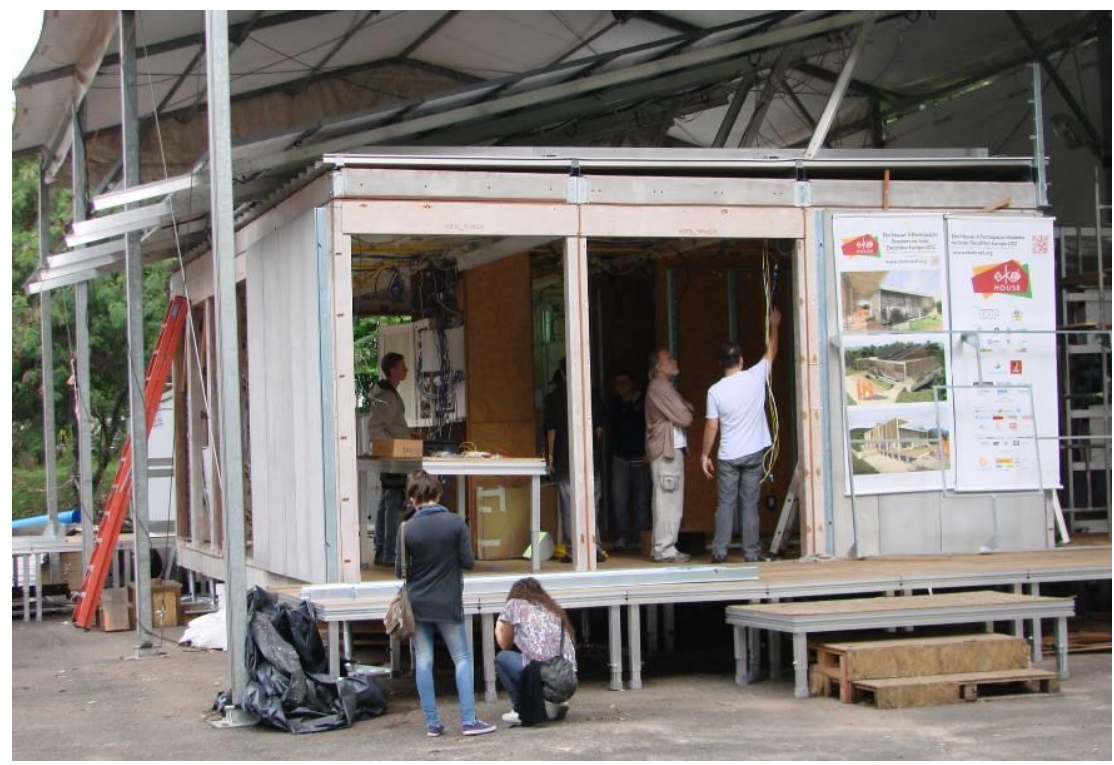

Figura 55 Vista geral da construção do protótipo

Fonte: Mattaraia (2012)

Para facilitar a montagem, a residência é composta por módulos, isto também dá a possibilidade de adicionar mais ambientes. A estrutura é de elementos pré-fabricados, o que também contribui para a montagem e desmontagem. O sistema estrutural é de aço galvanizado e madeira cumaru, para fazer alguns travamentos, painéis OSB para a vedação e há vários elementos e peças de alumínio. O piso da rampa de acesso e interno é de madeira. Os caixilhos são de PVC, com vidros insulados duplos.

A construção se iniciou em março de 2012 e em julho de 2012 foi realizada a desmontagem do protótipo para enviar a residência para o concurso na Espanha. 0 processo durou em torno de uma semana. Primeiramente foram desmontados os 
elementos externos, como brises e decks. Posteriormente os painéis fotovoltaicos, a cobertura, lajes, painéis de vedação, lajes de piso e fundação. Seguindo praticamente as etapas inversas da construção. A remontagem também durou cerca de uma semana.

Grande parte da construção foi realizada com ferramentas pequenas e de fácil manuseio, com exceção da colocação das lajes e da cobertura, que precisaram ser içados. Mas o processo foi rápido, quando comparado a uma construção convencional, pois foi possível montar três módulos de laje em duas horas.

$\mathrm{Na}$ desmontagem, também muitos elementos foram retirados manualmente, no entanto, os painéis de vedação, lajes e alguns elementos da cobertura tiveram que ser içados. As lajes e painéis verticais também tiveram que ser içados, levou certa de meia hora para desmontar cada painel, retirar e colocar na estrutura montada para transportar as placas, dentro do container.

As figuras 56 a 60 mostram alguns detalhes de encaixes e peças utilizadas para montar as estruturas.

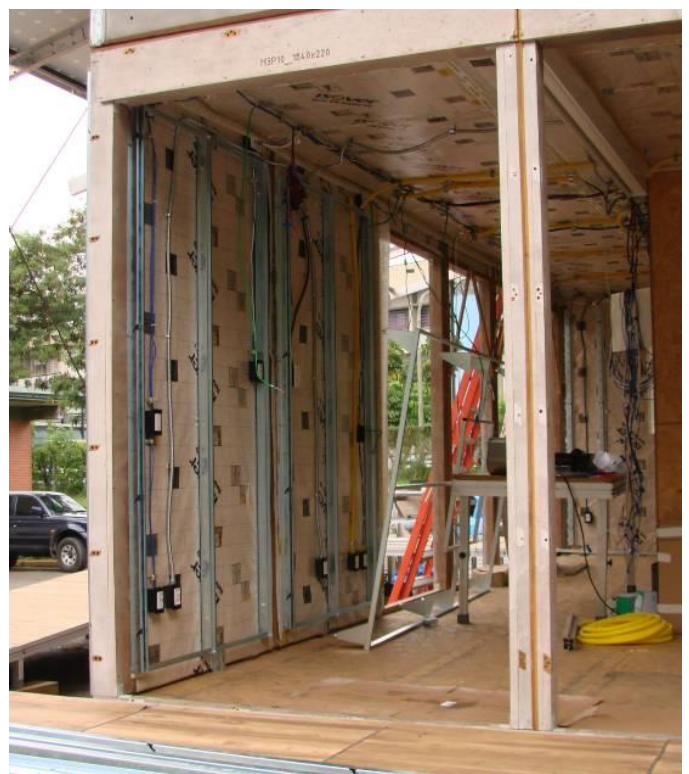

Figura 56 Vista interna Fonte: Mattaraia (2012)

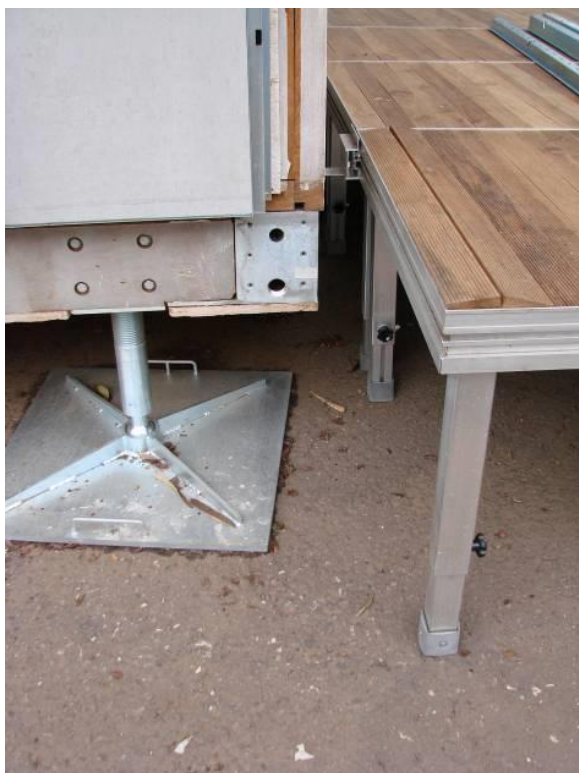

Figura 57 Detalhe do apoio da casa e da rampa Fonte: Mattaraia (2012) 

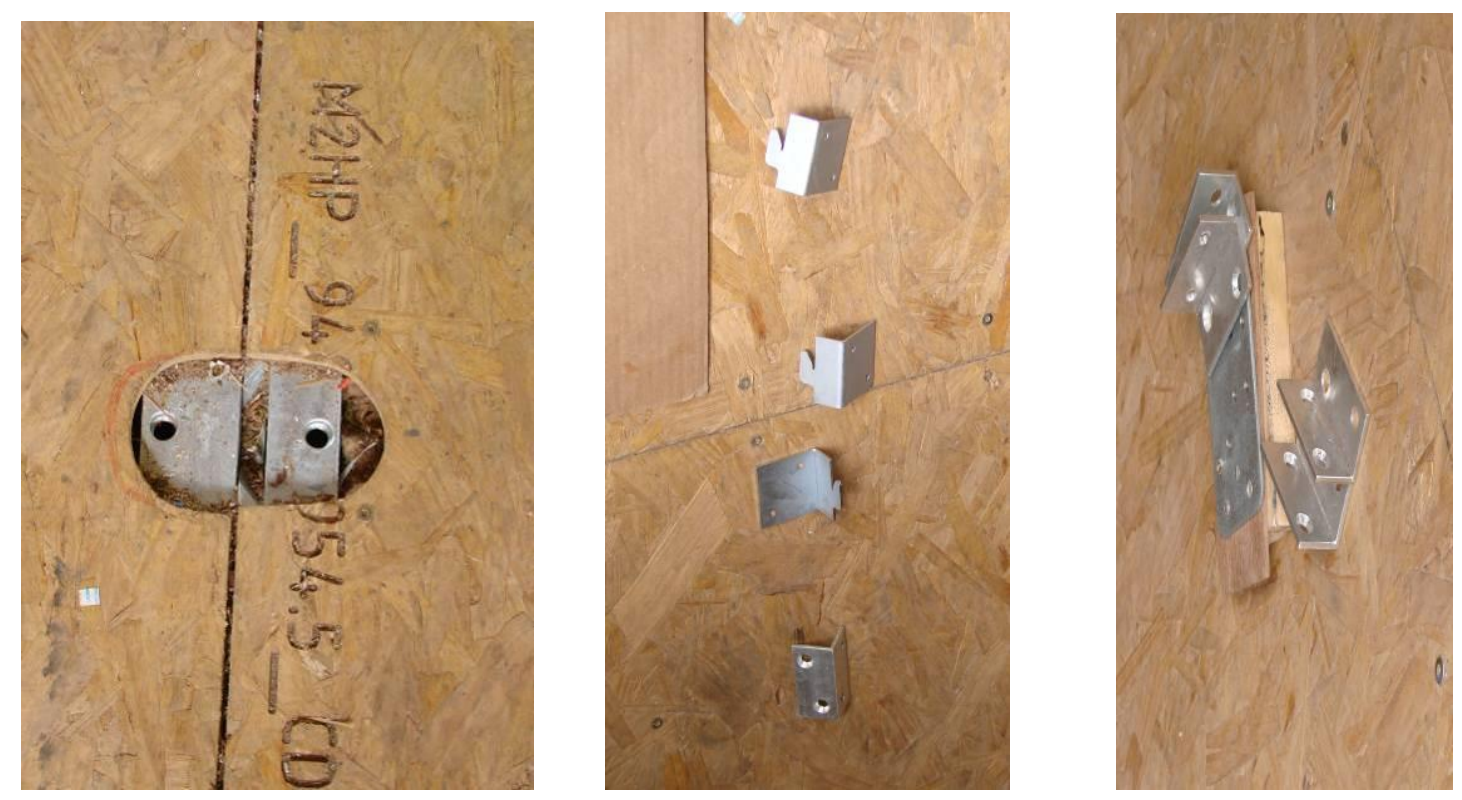

Figura 58, 59 e 60 Peças utilizadas na fixação da estrutura Fonte: Mattaraia (2012)

Todas as peças, elementos e módulos eram numerados, para facilitar a construção, desmontagem e montagem.

Para facilitar a desmontagem e o transporte, os painéis foram desmontados, com os sistemas elétrico e hidráulico já fixados entre eles, tipo "sanduíche", onde o módulo é formado por dois painéis e entre eles passam o sistema elétricos e hidráulico. Há possibilidade de retirar uns dos painéis caso seja necessário a manutenção.

Na figura 63 é interessante notar como são feitas as conexões do sistema elétrico, pois os painéis laterais serão separados da laje de cobertura e isto evita danos nos fios e cabos elétricos na desmontagem, além de facilitar a instalação na remontagem.

Na desmontagem e montagem do protótipo não houve geração de resíduos. Isto é muito importante, pois evita desperdícios de materiais e poluição ambiental. 


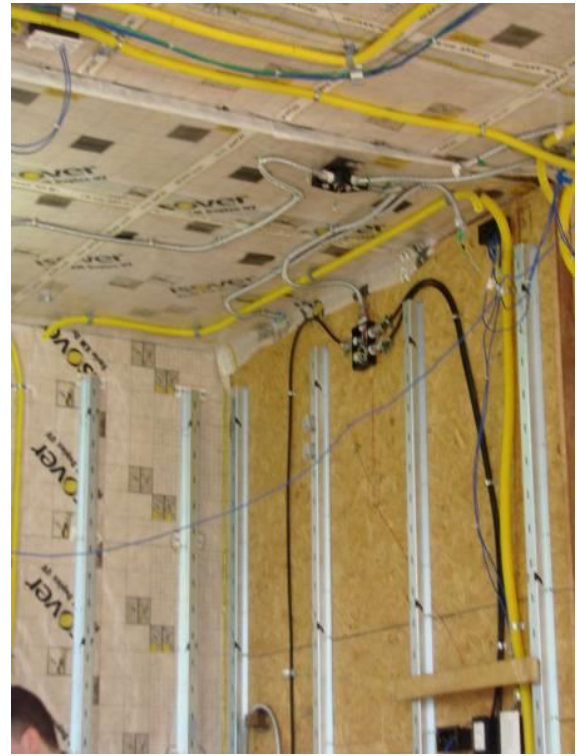

Figura 61 Detalhe instalações elétricas Fonte: Mattaraia (2012)

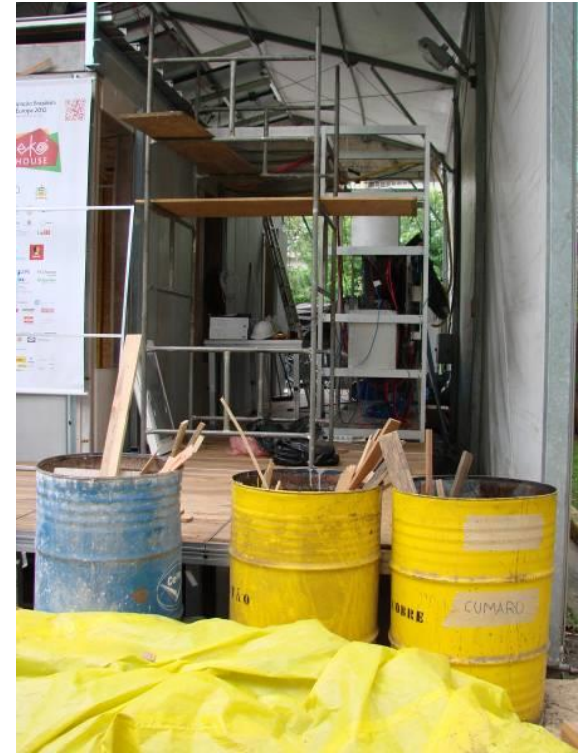

Figura 62 Resíduos fonte: Mattaraia (2012)

Todos os painéis e pisos são aparafusados, pois facilita o desmonte sem prejudicar as peças. Também tem elemento que foram encaixados, como o piso do deck externo. Apenas algumas peças tiveram que ser soldadas, mas não seriam desmontadas, pois o a soldagem impossibilita o desmonte.

Outro detalhe que facilita o desmonte foi a instalação das telhas metálicas que foram prensadas e estancadas por uma máquina, depois passa a máquina novamente para separá-las. As placas solares também foram prensadas nas telhas, assim não foi necessário furar e danificar as telhas.

Conforme os elementos fossem desmontados eram armazenados para o transporte. Todos eram identificados e numerados, conforme as figuras 63, 64 e 65 . 

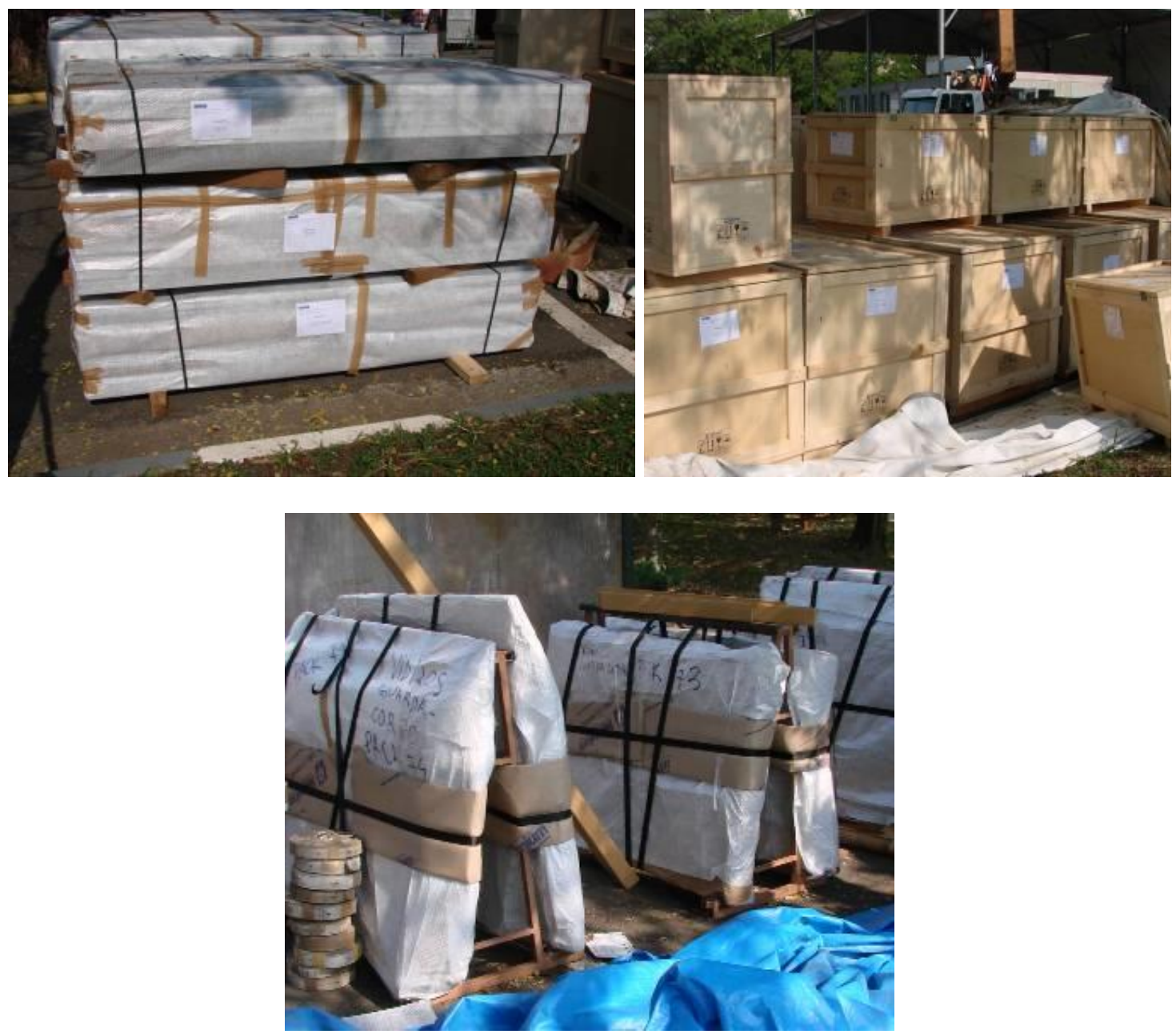

Figuras 63, 64 e 65 Armazenamento de peças e elementos do protótipo fonte: Mattaraia (2012)

As figuras 66 a 71 demonstram o processo de desmontagem de um dos painéis de vedação do protótipo. O elemento é desmontado, o caixilho e instalações elétricas e hidráulicas acompanham o módulo.

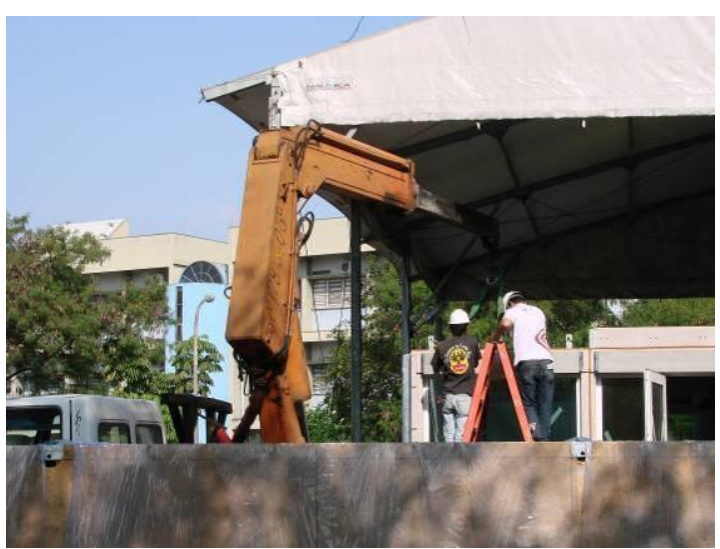

Figura 66 Içamento de um painel Fonte: Mattaraia (2012)

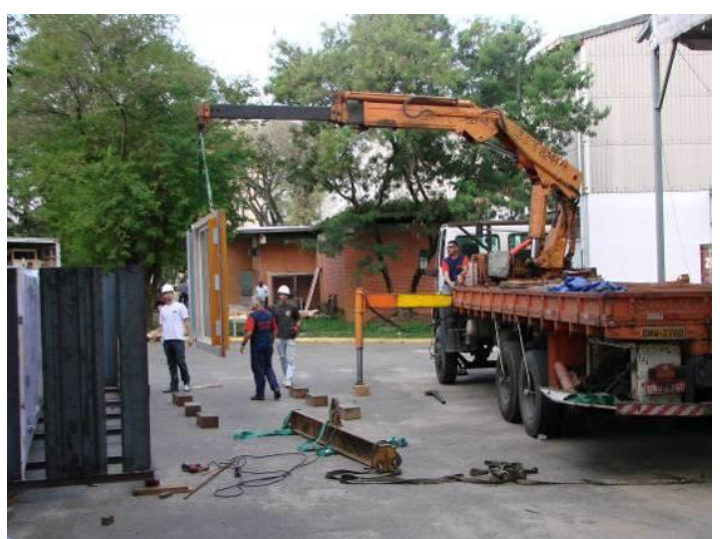

Figura 67 Retirada do painel Fonte: Mattaraia (2012) 

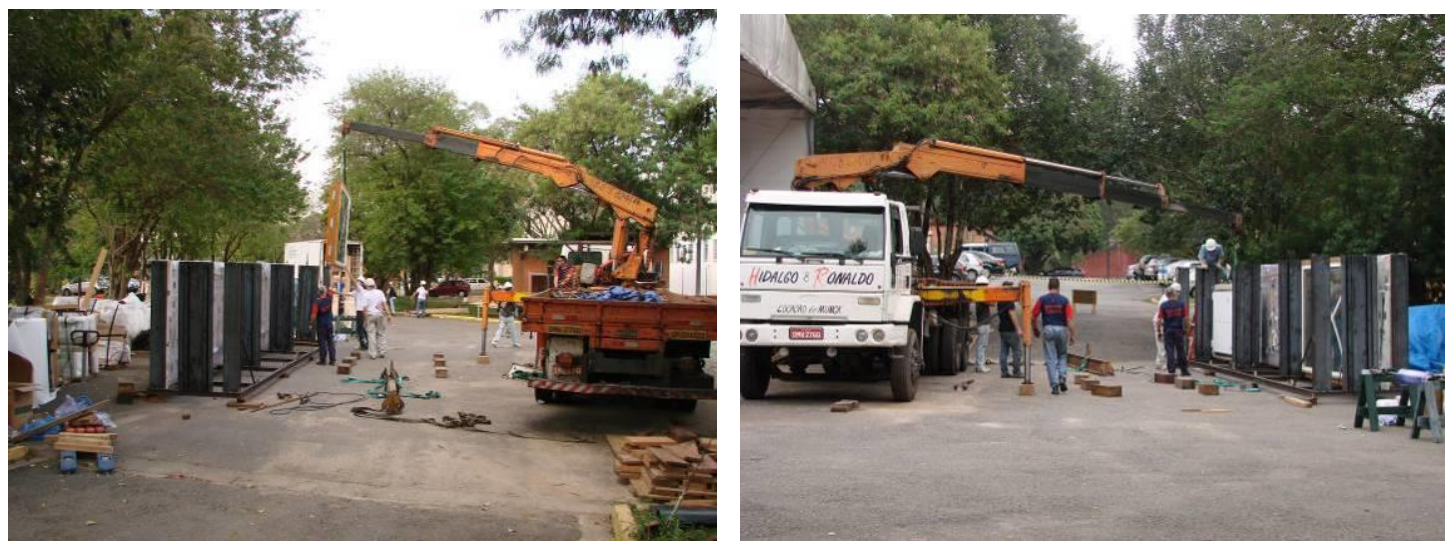

Figura 68 e Figura 69 Armazenamento do painel Fonte: Mattaraia (2012)
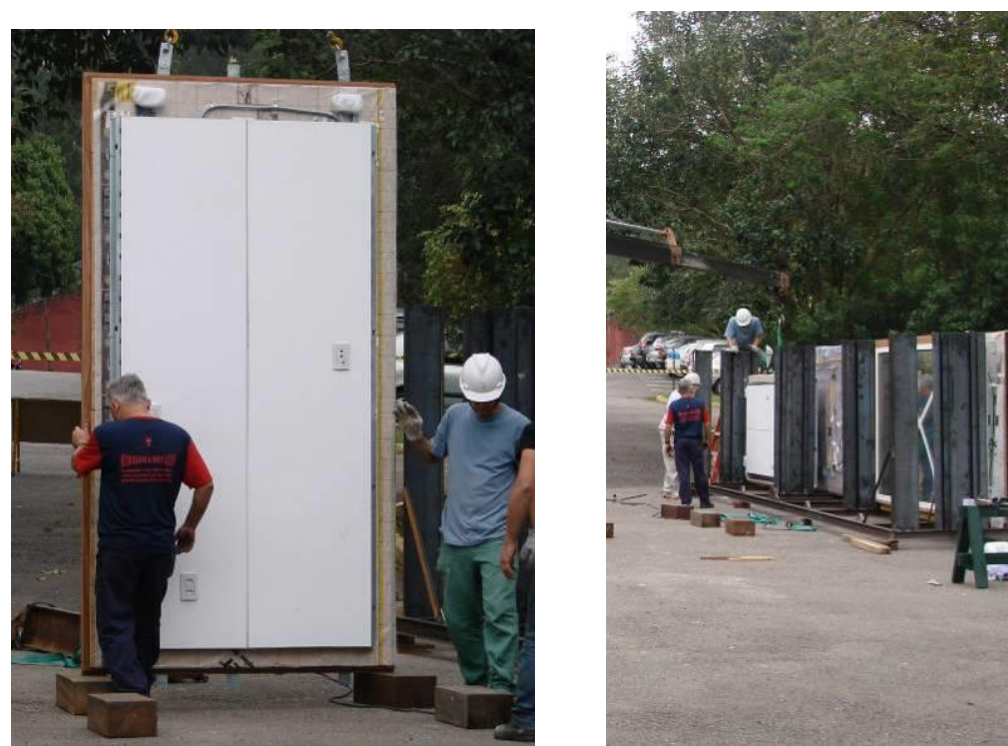

Figura 70 e 71 Um dos painéis içados e armazenado Fonte: Mattaraia (2012)

Os módulos eram desmontados, içados e encaixados em uma estrutura metálica que foi colocada dentro dos containers, para que fossem transportados com segurança. Desde o projeto foi considerado a dimensão dos containers.

No total foram 6 painéis para laje de forro, 6 para lajes de piso e 21 painéis verticais. Foram utilizados 8 mil parafusos e foram estudados e calculados todos os furos e encaixes14.

${ }^{14}$ Informações fornecidas em entrevista realizada com a Prof. Cláudia Oliveira. 
A figura 72, 73 e 74 é o protótipo montado na Espanha, para o concurso. Até mesmo internamente, deveriam ter todos os eletrodomésticos e cômodos de uma residência. É composto por salas, cozinha, quarto, banheiro, área de serviço externa e varanda.

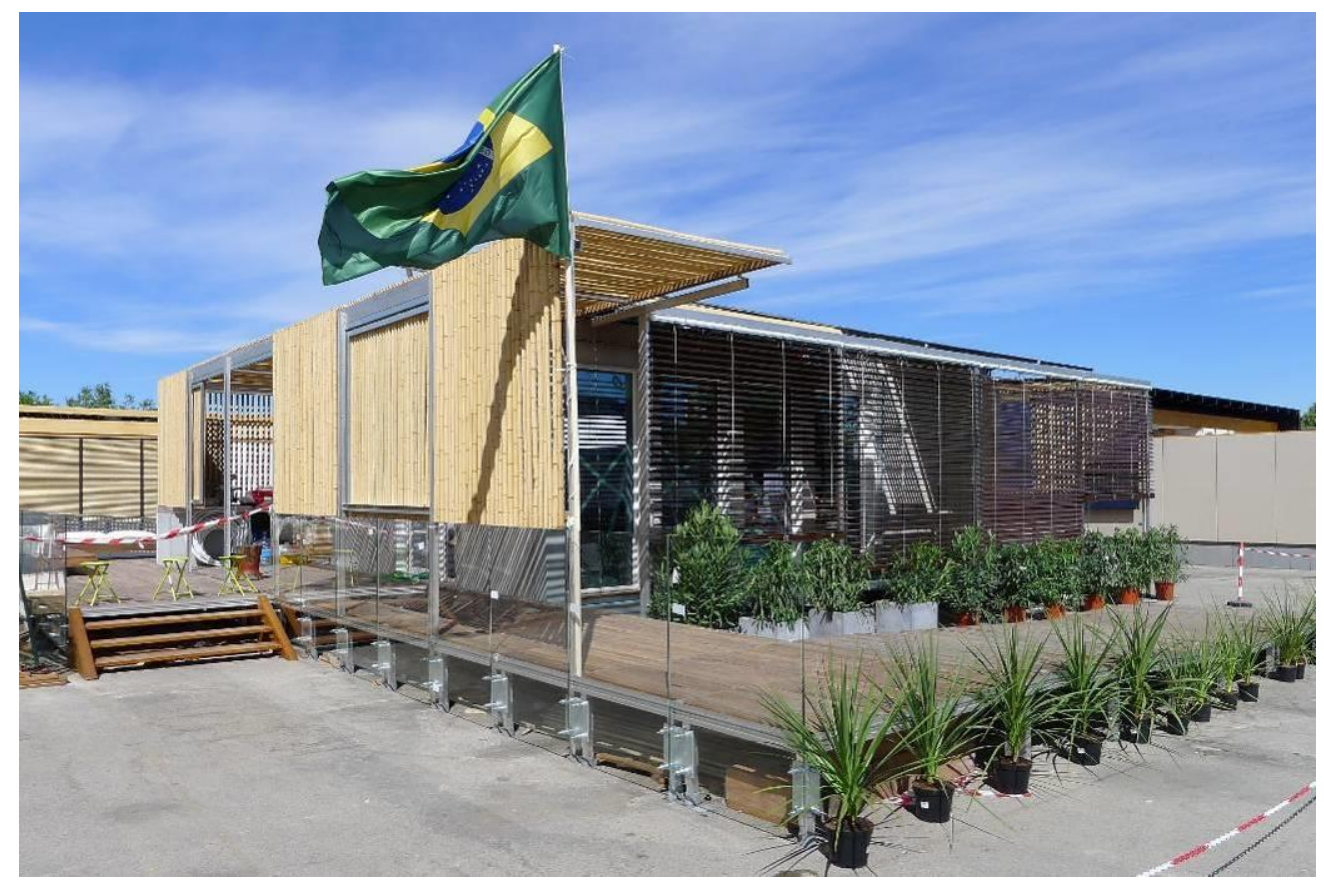

Figura 72 Ekohouse remontada para o concurso na Espanha

Fonte: http://www.facebook.com/ekohouse?fref=ts (acesso 11/12/12)
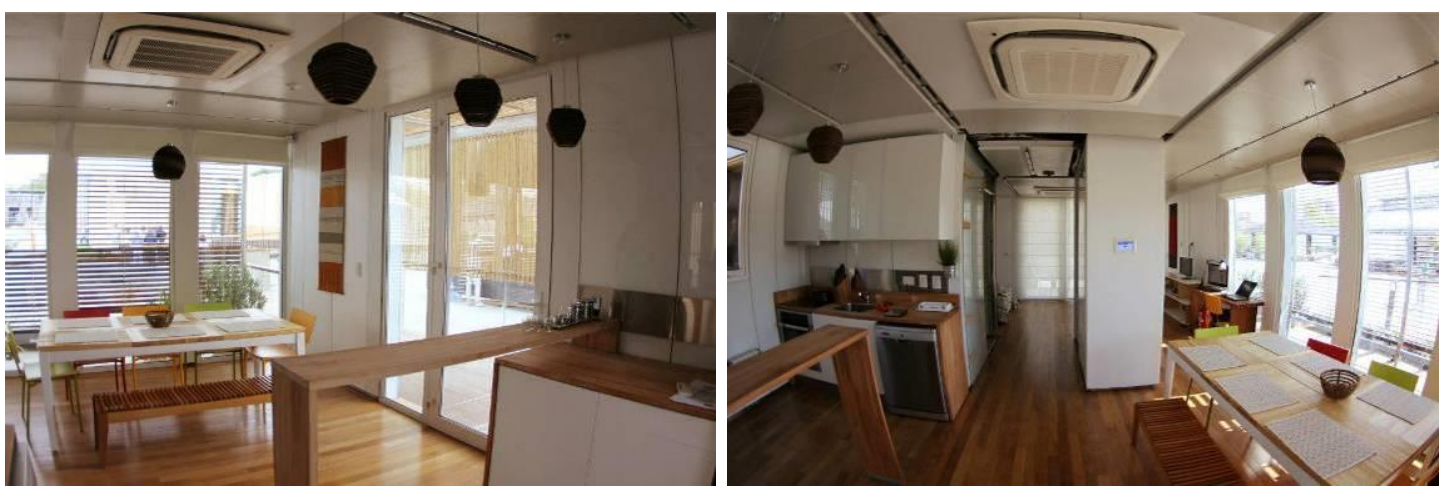

Figuras 73 e 74 Interior do Protótipo

Fonte: http://www.facebook.com/ekohouse?fref=ts (acesso 11/12/12)

Neste caso, foi muito interessante analisar a importância de incorporar alguns conceitos do Projeto para o Desmonte, mesmo não sendo o foco principal. Os elementos não seriam reutilizados em outras construções, mas mesmo desmontando e montado a construção, exatamente como era, foi possível analisar diversas características importantes. 
As peças, ferramentas, encaixes, modulações, tornaram possível a desmontagem do protótipo sem que danificassem os materiais e elementos. Assim, este estudo forneceu importantes características a serem consideradas no projeto, para facilitar a desmontagem, mesmo de materiais e elementos que podem ser utilizados em outras construções ou até para a reciclagem.

Além disso, foi possível notar que a ordem da desmontagem (quando possível) e demolição é o inverso da construção. Nos dois casos estudados se inicia com o telhado, depois revestimento, diversos subsistemas e por ultimo elementos estruturais.

\subsection{Análise dos Dados}

Neste item, serão apresentadas as análises dos dados obtidos com as pesquisas empíricas. Além disso, serão apresentadas diretrizes que possam contribuir com o Projeto para o Desmonte.

No estudo da demolição convencional, foi possível notar que atualmente é possível separar, para uma futura reutilização, apenas alguns materiais e elementos. A maioria deles vão para aterros e resulta em poluição e impacto ambiental.

Isto demonstra a necessidade de buscar a soluções para o fim da vida útil dos edifícios e encontrar maneiras de melhorar a desmontagem para obter melhores materiais para reutilização futura. Uma maneira de fazer isso é buscar melhores soluções durante a fase de desenvolvimento do projeto.

Neste estudo, foi possível ver quais materiais poderiam ser removidos sem comprometer seriamente a sua qualidade, para que possam ser reutilizados, e quais partes tiveram que ser demolida pela máquina e foram removidas apenas como entulhos. Como visto na literatura algumas características como ligações químicas, não 
considerar a ACV, mistura de materiais, falta de separação por camadas, utilização de materiais não resistentes, podem contribuir para a pouca recuperação de materiais e componentes.

Por outro lado, foi possível notar algumas características que contribuíram para a desmontagem de alguns elementos. Por exemplo, as madeiras utilizadas na estrutura do telhado foram ligadas por pregos e parafusos, o que facilita a desmontagem, além disso, o material estava em boas condições para reutilização futura. As dimensões das peças também contribuíram, pois são fáceis de manusear e transportar.

Nos estudos sobre reutilização de materiais foi possível perceber que é possível obter bons resultados, no entanto, se nas construções originais fosse considerado o conceito de Projeto para o Desmonte, seria possível obter resultados ainda melhores. Tanto em relação à quantidade de materiais reaproveitados, quanto mais rapidez no desmonte e menor custo.

Outro ponto interessante é que nos dois casos as edificações chegaram ao fim da vida útil não porque os materiais estavam danificados e tiveram que fazer reformas ou reconstruções e sim porque o uso havia mudado, mas os materiais continuavam em bom estado.

No caso do reaproveitamento da cobertura em estrutura metálica, o hangar não chegou a ser utilizado, pois o curso foi cancelado e a estrutura estava apenas abandonada. No caso das tulhas, as fazendas seriam vendidas e elas não seriam mais necessárias.

Segundo os arquitetos entrevistados, o processo de projeto não foi muito diferente de outros projetos realizados por eles. Ambos já trabalharam com outros projetos que também reutilizaram materiais. Isto é muito importante, pois demonstra que não é 
necessário intervenções radicais no processo de projeto para se obter bons resultados com o reaproveitamento de materiais. No entanto, foi essencial considerar o conceito desde o início do desenvolvimento do projeto.

Também foi importante observar a mudança do conceito no fim da vida útil dessas duas edificações (tulhas e hangar), pois poderiam ter sido apenas demolidas. Porém, as pessoas envolvidas, proprietários e arquitetos, perceberam que havia materiais nobres que poderiam ser reutilizados.

Nos estudos sobre reaproveitamento de materiais foi possível observar algumas vantagens:

- Buscar soluções na fase do projeto para melhor aproveitamento dos materiais resultou em bons resultados e evitou perdas;

- Reduz a quantidade de entulhos gerados com a demolição;

- Com o sistema estrutural em madeira e metálica foi possível grande aproveitamento, sem apresentar perdas consideráveis;

- Aumento do ciclo de vida dos materiais;

- Reduz o consumo de matéria-prima, evitando a produção de novos materiais;

- É mais vantajoso, até mesmo que a reciclagem, pois o material não precisar ser remanufaturado;

- Neste caso da reutilização da madeira, foi possível obter ganhos estéticos, além de técnicos e funcionais;

- No caso da estrutura metálica, os materiais ficam parecendo novos;

- Foi possível realizar uma construção mais sustentável;

- Aceitação do sistema estrutural reutilizado, pelos os usuários.

No entanto, também há algumas desvantagens:

- Mão de obra especializada e mais cuidadosa, isto pode gerar maior custo;

- Em alguns casos, não há padronização das peças; 
- É necessário fazer adaptações minuciosas, pois cada peça possui características próprias;

- Transporte e manuseio cuidadoso dos materiais;

- Demanda mais tempo, pois cada adaptação é específica;

- É importante cuidado e atenção para realizar a desmontagem.

No estudo do Desmonte Programado foi interessante observar a necessidade do desenvolvimento tecnologias para atender a necessidade de desmontar as edificações, ou parte delas. Isto demonstra a importante de inserir o conceito do Projeto para o Desmonte na concepção do projeto.

Outro ponto interessante é o que o projeto previa ampliações, no entanto, para que a ampliação fosse feita seria necessário demolir uma parede maciça de concreto e não havia previsão de como isto seria realizado.

Também neste caso, foi necessário fazer o desmonte devido à mudança de necessidade da edificação, que neste caso precisou ser ampliada, e não devido à deterioração.

No estudo da Ekohouse foi interessante observar diversos aspectos que facilitaram a desmontagem, sem que os materiais e elementos fossem danificados. Muitas decisões tomadas na fase de projeto foram essenciais para obter um bom resultado.

Uma das escolhas foi evitar ligações químicas e utilizar ligações por pregos, parafusos, conectores e encaixes. Isto permitiu que os elementos fossem desmontados de maneira prática e eficiente.

A utilização de ferramentas manuais também facilitou o processo, pois o trabalhador conseguia desmontar diversas partes, usando a mesmas ferramentas, em pouco tempo. 
As dimensões das peças também facilitaram no desmonte e transporte. Muitos elementos foram projetados para serem desmontados em peças leves e pequenas. Apenas os módulos principais (painéis de laje e vedação) que foi necessário içar para colocar na estrutura de transporte.

Os sistemas elétricos e hidráulicos também facilitam a manutenção, quando comparado ao sistema convencional que ficam embutidas na alvenaria. Assim é possível trocar peças e materiais sem danificar outros elementos. Os sistemas ficam embutidos nas placas de madeira, como um sanduíche, que podem ser desmontada para a manutenção.

Incorporar o conceito do Projeto para o Desmonte está altamente relacionado com o desenvolvimento sustentável da construção civil. Com a aplicação deste conceito foi possível desmontar diversas peças e elementos da construção sem que gerasse resíduos ou desperdício, além disso, nenhum elemento foi danificado durante a desmontagem.

Considerar o ciclo de vida dos materiais também foi muito importante. Primeiro porque a equipe buscou utilizar materiais que gerassem menor poluição durante sua produção e transporte, além de selecionar materiais resistentes que suportassem a montagem e desmontagens. 


\section{DIRETRIZES}

Neste capítulo são apresentadas diretrizes para a aplicação do Projeto para o Desmonte na construção civil, além disso, foram desenvolvidos dois checklists que visam tornar sua utilização mais ágil e prática.

Ao longo do trabalho é possível perceber a importância em considerar o desmonte e suas vantagens. A revisão bibliográfica, assim como os estudos empíricos, forneceram importantes informações para desenvolver diretrizes que podem auxiliar na aplicação do conceito no desenvolvimento do projeto. Elas foram criadas para serem utilizadas desde as concepções iniciais do edifício, pelos projetistas, com o intuito de facilitar o desmonte futuro.

Como analisado na revisão bibliográfica e observado nos estudos de caso, atualmente não é comum que os projetistas considerem o fim da vida útil das construções. Dessa maneira, quando chega ao fim, a única opção é demolir, isto resulta em poluição e desperdício.

Nos casos analisados foi observado que as edificações não foram desmontadas ou demolidas devido ao desgaste dos materiais, sistemas ou componentes e sim pela mudança do uso. Isto demonstra a necessidade de considerar o desmonte, pois muitas vezes, os edifícios não são utilizados tanto tempo quanto são programados e resultam em grande desperdício de materiais que poderiam ser reutilizados.

Com as questões ambientais cada vez mais presentes nas legislações e exigidas pelos consumidores torna-se imprescindível buscar soluções para colaborar com o desenvolvimento sustentável. Deste modo, as diretrizes podem contribuir com a redução de tempo e custo na desmontagem, permitir que os materiais possam ser revendidos com maior qualidade e mantendo suas características originais, além de 
cooperar com a redução de consumo de matérias-primas na produção de novos materiais.

Para Crowther (2005) é importante projetar de maneira sustentável e o DFD pode contribuir. Heriqson, Rocha e Sattler (2008), Guy e Shell (2002), Webster e Costello (2005) também evidenciam a necessidade de projetar considerando o Desmonte.

No entanto o processo deve ser ágil, como menciona Manzini e Vezzoli (2008). Assim essas diretrizes têm como objetivo fornecer informações para facilitar o procedimento. Outro propósito das diretrizes é aumentar a possibilidade de reutilização e reciclagem dos materiais. Manzini e Vezzoli (2008), Guy e Rocha (2005), Go, Wahab et al (2011), Romeiro Filho (2010), Klon e Ferreira (2009) afirmam que umas das principais características do DFD é auxiliar a reutilização e reciclagem, assim não basta apenas desmontar, mas deve-se ter o cuidado para não inutilizar os materiais.

Assim, foram desenvolvidas diretrizes, através de reunião de dados da revisão bibliográfica e dos estudos empíricos, para auxiliar a aplicação do Projeto para o Desmonte, pelos projetistas, desde a concepção inicial do projeto, de maneira mais prática e eficiente.

\subsection{Processo de desenvolvimento das diretrizes}

As diretrizes foram desenvolvidas com base nas informações obtidas ao longo da revisão bibliográfica e dos estudos empíricos. Muitos dados analisados nas pesquisas teóricas foram confrontados quando com os casos práticos que forneceram importante material para o desenvolvimento das diretrizes. Alguns exemplos serão citados para melhor compreensão sobre a cencepção das diretrizes no presente trabalho. 


\subsubsection{Exemplo relacionado à Demolição Convencional}

Neste caso foi possível observar que alguns materiais puderam ser retirados para futura revenda e outros não. As madeiras que compunham a estrutura do telhado, por ser um material resistente, padronizado, ter dimensões compatíveis com a escala humana e ligações que permitiam serem desfeitas sem danificar tanto o material, permitiu que fosse retirada para futuro reaproveitamento.

Enquanto que o gesso que não é um material muito resistente à desmontagem, não é padronizado (depois que instalado) e tem ligações químicas, não resistiu à desmontagem e não pode ser reaproveitado.

Nas figuras 75 é possível observar as madeiras retiradas do telhado, em bom estado e com possibilidade de ser reaproveitada. Enquanto que na imagem 76, o gesso que foi utilizado no forro está quebrado e não será reutilizado.
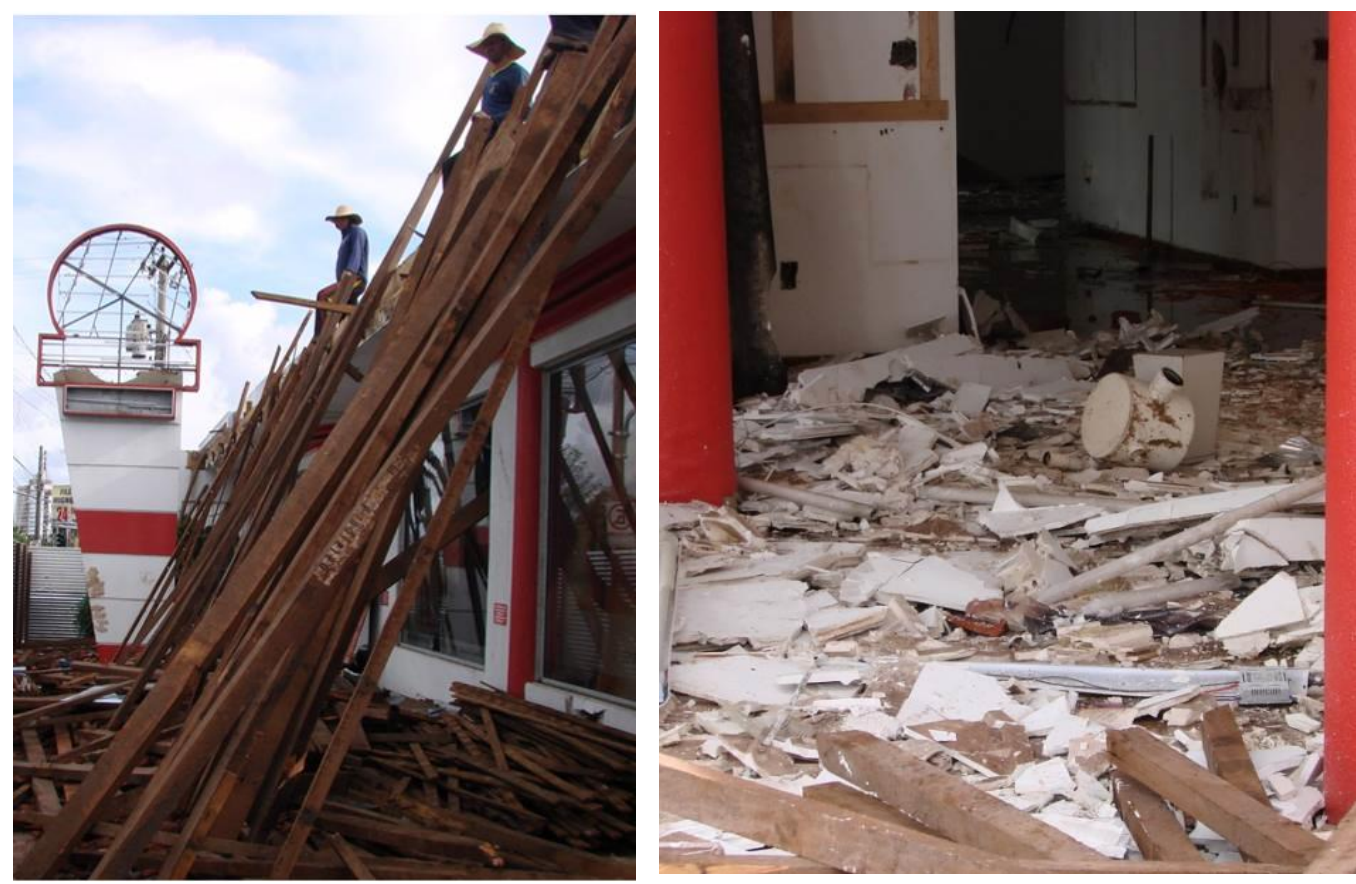

Figura 75 Madeira retirada da obra e Figura 76 gesso quebrado Fonte: Mattaraia (2012)

Os autores Heriqson, Rocha e Sattler (20085); Crowther (1999); Guy e Shell (2002);

Webster e Costelo (2005), também citam estas características a serem analisadas no 
Projeto para o Desmonte. Assim com a união destas informações foram desenvolvidas as diretrizes que serão mais bem exploradas no item 6.2.

\subsubsection{Exemplo relacionado à Demolição Programada}

Neste estudo foi interessante observar muitas características referidas na revisão bibliográfica e que contribuíram com o desenvolvimento das diretrizes, como por exemplo, a falta do Projeto considerar o Desmonte, pois neste caso, era necessário demolir uma parede de concreto maciça, para ampliação da eclusa.

Como não havia previsão da maneira que isto seria feito, foi necessário utilizar uma técnica adaptada $^{15}$ para este tipo de situação. Além disso, as peças cortadas possuíam grandes dimensões e dificilmente poderiam ser reutilizadas.
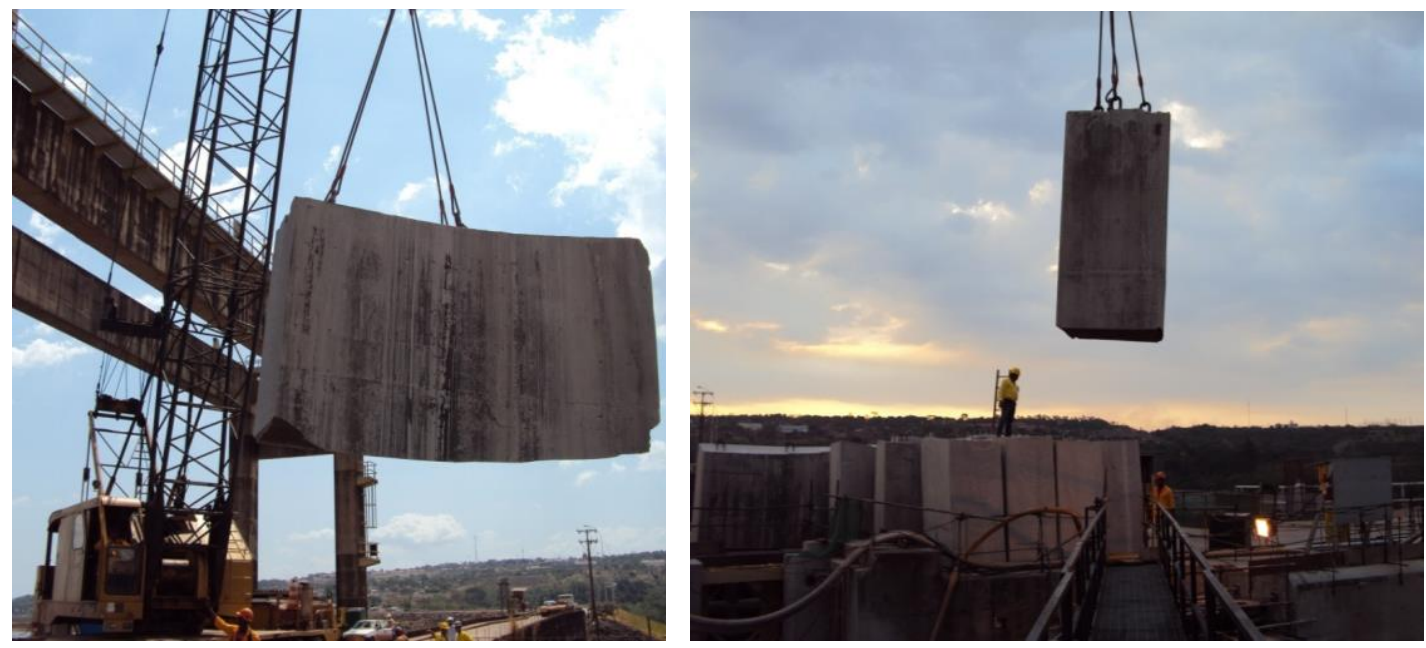

Figura 77 e Figura 78 Peças de concreto maciço resultado do corte da parede da eclusa Fonte: engenheiro da empresa $A$ (2009)

\footnotetext{
15 Máquina com corte de fio adiamantado, como foi explicado no Capítulo 05.
} 
Estas características também são citadas pelos autores Heriqson, Rocha e Sattler (20085); Crowther (1999); Guy e Shell (2002); Webster e Costelo (2005), como pontos a serem analisados para facilitar o Projeto para o Desmonte.

\subsubsection{Exemplo relacionado ao Reaproveitamento de Materiais}

Nos casos sobre reaproveitamento de materiais, do clube de golfe e do ginásio da USP, onde foram reaproveitados diversos materiais, foi possível observar algumas características citadas na revisão bibliográfica pelos autores Heriqson, Rocha e Sattler (20085); Crowther (1999); Guy e Shell (2002); Webster e Costelo (2005), entre outros.

Para a reutilização foi importante a identificação dos materiais, pois quando utilizados originalmente, as estrutura e os tijolos não estavam revestido e foi fácil identificar apenas visualmente. Outra característica foi a pouca variedade de materiais, no hangar só havia estrutura metálica, apoiada em uma estrutura de concreto (que não pode ser reaproveitada). Nas tulhas, os materiais predominantes eram madeira, tijolos e telhas, estes materiais também foram reaproveitados.

Outra característica foi a vida útil dos materiais, a madeira, o metal, os tijolos maciços de barro e telhas, quando bem cuidados, podem ter a duração de muitas décadas. Assim ainda estavam em ótimas condições e puderam ser reaproveitados.

Na figura 79 é possível observar os materiais reciclados, madeira e tijolos. Na figura 80, a estrutura metálica original do Hangar que foi utilizada no Ginásio. 

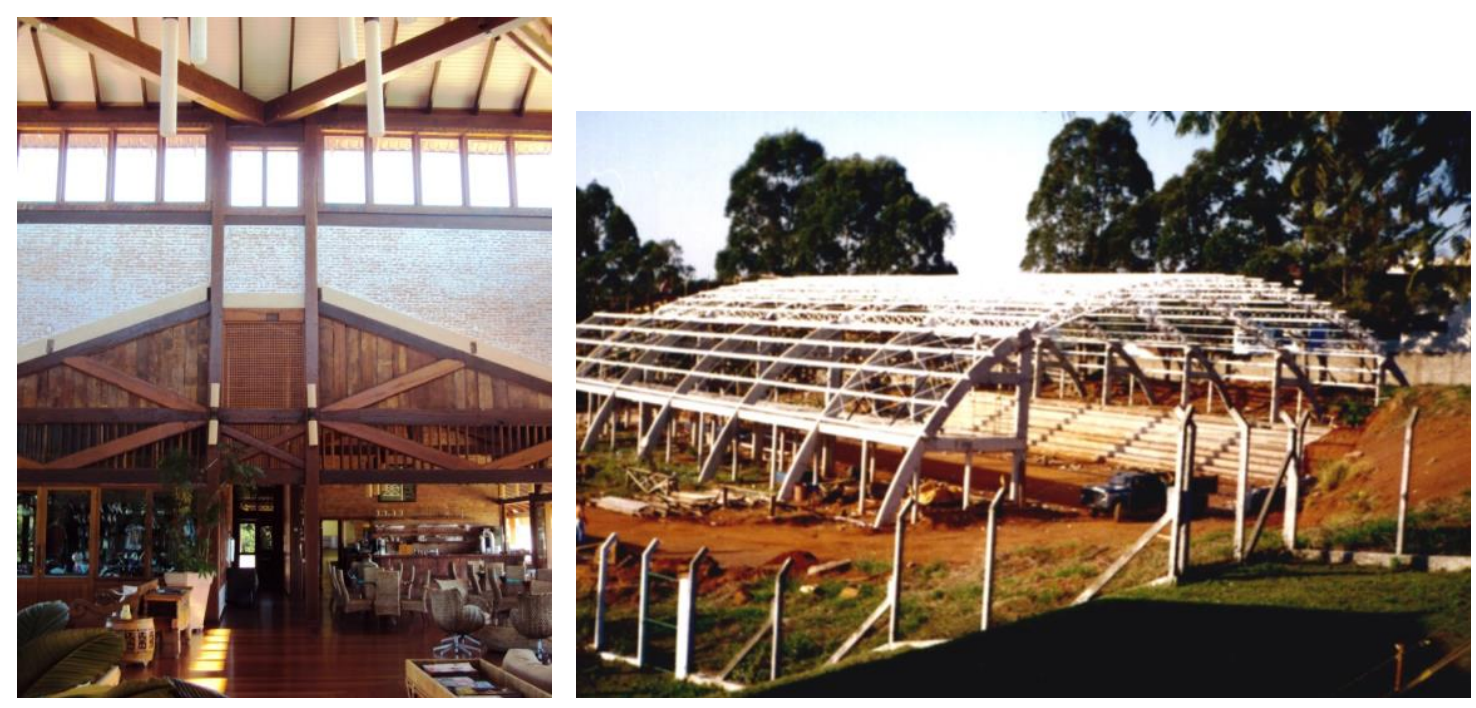

Figura 79 e 80 Materiais reutilizados no clube de Golfe e no Ginásio Fonte: Mattaraia (2012) e Fonte: prefeitura da USP-SC (1998)

\subsubsection{Exemplo relacionado a Eko House}

No estudo de caso da Eko House também foi possível observar diversas questões abordadas na revisão bibliográfica. A sequência da construção e desmontagem deve ser considerada, pois pode auxiliar o futuro desmonte. Neste caso foi possível observar que a desmontagem segue a sequência inversa da construção, pois os primeiros elementos a serem retirados, foram os últimos a serem montados. Considera que o edifício é composto por camadas, como estrutura, vedação, cobertura, também é essencial para obter melhores resultados na desmontagem.

Além disso, foi interessante analisar que foi considerada a tecnologia disponível e acessível para a construção e desmontagem. A máquina mais complexa utilizada foi um munque, para retirar alguns elementos, como as lajes e paineis, mas grande parte da construção foi desmontada com ferramentas manuais. Na figura 81 é possível observar as algumas camadas da Eko House e na figura 82 a desmontagem das lajes de painéis. 

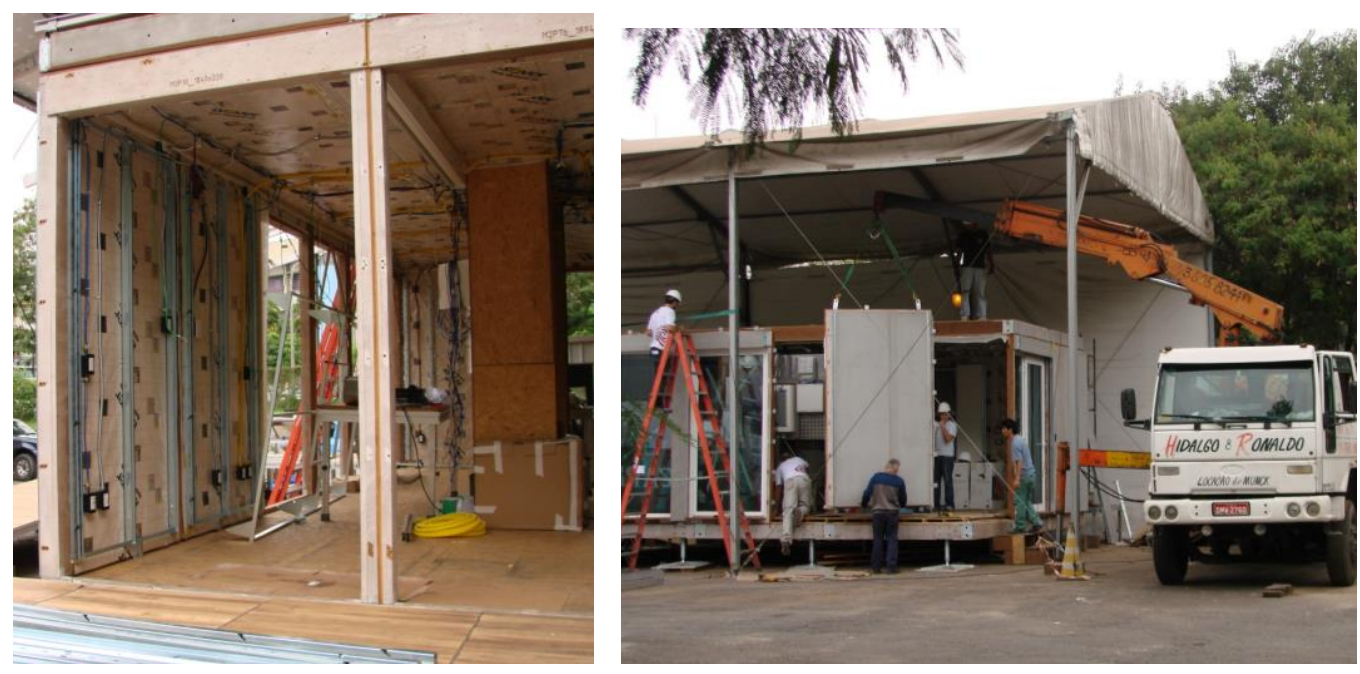

Figura 81 e Figura 82 Imagens da Eko House na fase de montagem e desmontagem Fonte: Mattaraia (2012)

Os autores Heriqson, Rocha e Sattler (20085); Crowther (1999); Guy e Shell (2002); Webster e Costelo (2005) também abordam estas questões.

Assim, com análises das questões reunidas na revisão bibliográfica e observadas nos estudos empíricos, foi possível construir as diretrizes para auxiliar na aplicação do Projeto para o Desmonte, pelos projetistas, na fase de desenvolvimento do projeto. As diretrizes devem ser consideradas desde a concepção inicial do projeto, até os detalhamentos finais.

\subsection{Diretrizes dispostas em grupos}

As diretrizes foram dispostas em diversos grupos para facilitar o entendimento e desenvolvimento de projeto. Elas devem ser utilizadas pelos projetistas, mas também é importante que os proprietários e usuários tenham ciência das questões abordadas. Os projetistas devem deixar claro e documentado os pontos abordados, pois talvez não acompanhem a desmontagem futura. As seguir são apresentadas as diretrizes disposta em grupos. 


\subsubsection{Quanto aos sistemas construtivos}

Os sistemas estruturais e construtivos tem papel fundamental no DFD. Através dos estudos realizados e da Revisão Bibliográfica, foi possível analisar diversas questões que devem ser abordadas no projeto, para obter melhores resultados.

Segundo Santini e Herman (2010) é importante projetar sistemas estruturais que facilitem o processo. Para Romeiro Filho (2010) uma maneira de fazer isso é utilizar estruturas simples. Para Yuba (2005), Webster e Costello (2005) adotar sistemas abertos também contribui. Além disso, para Webster e Costello (2005) também é importante evitar misturar diferentes sistemas construtivos.

Utilizar sistemas modulares é indicado, pois é possível programar melhor como será o processo de desmontagem e até planejar a maneira em que o sistema poderá ser reutilizado. Para Guy e Shell (2002), Webster e Costello (2005) um acordo entre o proprietário, arquiteto e engenheiro para buscar soluções estruturais que facilitem a reutilização é recomendável. Nos estudos da Eko House e da Cobertura do Ginásio de Esportes, foi observado que isto realmente facilita, já que nos dois sistemas haviam diversas peças repetidas, dispostas em sistemas modulares.

Empregar elementos pré-fabricados, por serem padronizados e auxiliarem na desmontagem mais prática e rápida, enquanto que a variedade de elementos dificulta o processo. Além disso, é interessante se estes elementos possuírem pontos específicos para a montagem. Também nos estudos da Eko House e do Ginásio, isto foi observado e realmente foi possível obter bons resultados. Para Heriqson, Rocha e Sattler (2008), Guy e Shell (2002), Webster e Costello (2005) a maneira com que o edifício é construído influencia diretamente na desconstrução. 
Buscar materiais e estruturas que contribuam com o desmonte, como estruturas metálicas e de madeira. Evitar concreto armado, por exemplo, pois o processo de separar o aço do concreto é complicado e as peças são pesadas e grandes demais para serem desmontadas e transportadas. Além disso, os elementos do concreto armando, principalmente os moldados no local, são interligados de uma maneira em que no final, toda a estrutura se transforma em apenas uma peça. Webster e Costello (2005) falam sobre as dificuldades e vantagens de diversas estruturas, conforme apresentado no ítem 3.3. Também nos estudos foi possível observar o comportamento dos diversos materiais, como na estrutura de madeira em que foi verificada a flexibilidade e possibilidades de reutilização; na estrutura metálica, todo o sistema pode ser reaproveitado, sem perdas, mas não permite muitas alterações; a eclusa, onde foi feita a demolição controlada, demonstra a dificuldade em desmontar estruturas de concreto, assim como no caso da demolição convencional; na Eko House, composta por estrutura metálica e painéis de madeira, também favoreceu o desmonte.

Evitar peças de grandes dimensões também é recomendável. Quando as peças são muito grandes e pesadas são necessários maiores equipamentos e oferecem mais riscos aos operários. No caso da Eclusa e da demolição convencional, fica claro como uma estrutura de concreto é difícil de ser demolida ou desmontada, em contraste com as estruturas metálicas e de madeira, composta por peças menores, em que é possível obter melhores resultados.

Estruturas resistentes e que permitem desmontagem e remontagem também são boas opções. Isto ficou muito claro no estudo sobre estrutura metálica, pois o material é muito resistente e pode ser totalmente reaproveitado. Além disso, para Guy e Shell 
(2002) deve-se utilizar materiais e componentes que possam se sustentar independentes.

Considerar como será feita a ligação entre a estrutura e os outros sistemas e subsistemas é essencial. Isto evita que peças e materiais sejam danificados. Esta questão pode ser analisada, principalmente, na fase de compatibilização dos projetos. Não é recomendável que a estrutura seja perfurada para passagem de encanamentos hidráulicos, por exemplo. Para Crowther (1999), Guy e Shell (2002), Webster e Costello (2005) também é importante considerar como será feita a separação da estrutura e compartimentos.

\subsubsection{Quanto aos materiais}

A análise dos materiais que serão utilizados é fundamental para obter melhores resultados na desmontagem e reutilização. Para Manzini e Vezzoli (2008) é importante expandir a vida útil dos materiais. Além de prevenir que se tornem tóxicos ou danosos.

Para Webster e Costello (2005) também é importante utilizar materiais que são fáceis de separar. Quando este processo é otimizado é possível obter resultados muito melhores e aumentar a qualidade dos materiais que serão utilizados. No estudo sobre demolição convencional foi possível observar que a maioria dos materiais era difícil de separar, assim gastava muito tempo e ainda era danificado, portanto, segundo os funcionários que estavam fazendo a demolição, não compensava desmontar. Os materiais mais fáceis, como telhas, estrutura do telhado em madeira, chapas metálicas, puderam ser desmontados.

Padronizar os materiais torna o processo mais eficiente e também favorece a organização, desmontagem e reutilização. Além disso, contribui para economia de 
tempo e reduz os gastos. Esta característica foi observada em vários estudos como na Eko House, onde os materiais tinham medidas padronizadas e modulares, também na Estrutura Metálica e Madeira.

Considerar a ACV dos materiais é necessário para verificar o tempo em que será utilizado sem prejudicar suas funções, além de programar a manutenção ou substituição. Analisar o fim do ciclo de vida ajuda a destiná-los de maneira correta, para a reutilização, reciclagem ou descarte. Isto agrega mais valor ao material que será reutilizado. Para Soares, Souza e Pereira (2006) a ACV é uma importante ferramenta para avaliar os materiais.

Evitar materiais tóxicos e danosos está diretamente relacionado ao item anterior, pois alguns materiais liberam mais toxinas em determinadas fases de seu ciclo, assim é importante considerar, principalmente, sua destinação final, para que não agrave ainda mais a poluição. Além disso, também não devem prejudicar a saúde dos usuários dos edifícios. O arquiteto, construtor e proprietário devem tomar este tipo de cuidado, como será mencionado no próximo item. Guy e Shell (2002), Webster e Costello (2005) e Romeiro Filho (2010) não recomendam utilizar materiais tóxicos. Este é uma grave questão que foi observada na Demolição Convencional, onde as luminárias, lâmpadas e gesso, que possuem toxinas, foram removidos misturados com os outros entulhos, e isto vai intoxicar o meio ambiente, pois será depositado em um córrego, com informou um dos funcionários da empresa, sem nenhum tratamento.

Cuidados ao utilizar materiais reciclados, pois é necessário analisar sua composição e se atendem com qualidade às necessidades exigidas. Além disso, é importante considerar as possibilidades de reutilização e reciclagem do material. Muitas vezes o material pode estar danificado e não cumprir corretamente sua função. 
Evitar materiais compostos, pois em grande parte dos casos, torna-se inviável a separação dos materiais. O concreto armado, por exemplo, é muito difícil de separar o aço do concreto, para possíveis reutilizações. Por isso, normalmente, este material precisa ser triturado e transformado em outro produto, como tijolos. Quando a estrutura é todo em madeira, assim como a vedação e caixilhos, o desmonte se torna mais prático, economiza tempo e reduz os custos. Além disso, normalmente, para cada material são necessárias ferramentas diferentes e são desmontados de maneira distinta, o que também atrapalha o processo.

Utilizar Materiais leves, por serem mais fáceis de serem manuseados, facilita e torna mais ágil o processo de desmontagem. Quando os materiais são leves, o transporte, armazenagem, montagem e desmontagem são bem mais fáceis. Isto pode ser observado no estudo do Clube de Golfe, pois os tijolos de barro puderam ser bem reaproveitados. No estudo da Demolição Convencional, as telhas cerâmicas, que são leves, também foram desmontadas para futura reutilização.

Utilizar materiais duráveis e resistentes, pois permite que sejam desmontados e reutilizados, mantendo suas características. Além disso, quando isto é possível revender, o preço é maior. Heriqson, Rocha e Sattler (2008), Guy e Shell (2002), Webster e Costello (2005) reforçam a importância em utilizar peças e materiais resistentes.

Reutilizar materiais de outras construções é uma maneira de incentivar a prática. Isto é citado por Heriqson, Rocha e Sattler (2008), Webster e Costello (2005), e também foi observado nos estudos sobre reutilização da Estrutura Metálica e de Madeira. Além disso, foi possível verificar que teve grande aceitação pelos usuários, suas características foram mantidas e desenvolveram muito bem sua função estrutural. 
Isto demonstra que quando a desmontagem e a reutilização são feita com precisão e cuidado é possível obter ótimos resultados. Utilizar materiais reciclados também incentiva a prática, mas é necessário tomar os devidos cuidados, como citado anteriormente.

Além disso, é importante priorizar materiais que possam ser reutilizados, sem precisar ser reciclados, como foi feito nos estudos da reutilização da Estrutura Metálica e de Madeira. Isto torna o processo de reutilização mais rápido, sem gerar poluição e consumir matérias-primas, com a produção de outro material.

Outra questão importante, citada por Webster e Costello (2005) é utilizar materiais que possam ser identificados visualmente. Isto facilita a identificação do material e é possível buscar a melhor maneira de desmontá-lo e reutilizá-lo. Nos casos da reutilização da Estrutura Metálica e de Madeira, na obra original, o material estava bem visível e fácil de identificar, assim facilitou muito o processo.

\subsubsection{Quanto aos revestimentos e acabamentos}

Os revestimentos e acabamentos também são peças fundamentais que devem ser considerados no Projeto para o Desmonte. Como foi observado nos estudos empíricos, às vezes, é possível removê-los sem danificá-los. No entanto, muitas vezes, não é possível reaproveitar, como na Demolição Convencional, onde os revestimentos foram colocados com argamassa e prejudicou a retirada deles, assim não puderam ser reaproveitados.

Evitar revestimentos e acabamentos químicos, como argamassa e pintura, pois dificulta a separação dos materiais. Por exemplo, no caso do reaproveitamento dos tijolos das tulhas, eles foram assentados com barro e não estavam revestidos, se tivessem rebocados e pintados, seria muito difícil ou até impossibilitaria o reuso. 
Especificar acabamentos encaixados, como alguns assoalhos de madeira ou pisos vinílicos. Os porcelanatos, por exemplo, precisam ser assentados com argamassa, isso dificulta a remoção e também o piso é danificado no processo, impossibilitando o reuso. Talvez a utilização de algum tipo de argamassa que não danifique tanto o produto quando for desmontado, seria uma boa solução.

Outra característica a considerar são as mudanças nos conceitos estéticos dos revestimentos. Todos os anos as indústrias lançam novos produtos, isto motiva a constante renovação dos ambientes e troca de revestimento. Optar por soluções que permitam a troca de materiais sem danificar os que já foram utilizados contribui para a redução do desperdício, pois podem ser revendidos ou reciclados.

\subsubsection{Quando às ligações e conexões}

As ligações e conexões são questões essenciais que devem ser abordadas no Projeto para o Desmonte. Elas podem contribuir com o reaproveitamento do sistema, materiais ou pode comprometê-los, inutilizando-os para futura reutilização. Para Santini e Herman (2010) é importante utilizar juntas que facilitem o processo. Segundo Romeiro Filho (2010) deve-se considerar os encaixes que facilitam a desmontagem.

Para Heriqson, Rocha e Sattler (2008), Crowther (1999), Guy e Shell (2002), Webster e Costello (2005) é necessário evitar ligações químicas. O ideal é considerar encaixes que possibilitem o desencaixe no futuro. Utilizar pregos, parafuso e conectores também são opções interessantes, desde que não danifiquem tanto as peças, após serem removidos. Nos estudos empíricos foi observado que quando se utilizou ligações químicas, como na Demolição Convencional e na Eclusa, foi muito difícil desmontar, assim foi necessário utilizar outras técnicas como a Demolição ou Demolição Programada. Enquanto que nos estudos sobre Estrutura Metálica, Madeira e na Eko 
House, onde foram utilizados encaixes, pregos e parafusos, foi possível obter melhores resultados, sem danificar os materiais.

Heriqson, Rocha e Sattler (2008), Guy e Shell (2002), Webster e Costello (2005) e Crowther (1999) sugerem utilizar parafusos e conexões que não danifiquem os elementos. Isto também foi observado nos estudos sobre Estrutura Metálica, Madeira e na Eko House, que foi mais fácil de desmontar, enquanto que na Demolição Convencional, os materiais foram danificados por utilizar ligações químicas.

Para Yuba (2005), Guy e Shell (2002), Webster e Costello (2005) também é importante facilitar a ligação das peças e montagem dos componentes, para obter melhores resultados na desmontagem e reaproveitamento dos materiais. Outra maneira de fazer isso, segundo Heriqson, Rocha e Sattler (2008) é propor ligações independentes. Nos estudos em que as ligações das peças eram assim (Estrutura Metálica, Madeira e na Eko House), foi possível obter melhores resultados.

\section{Utilizar conectores que resistam à montagem, desmontagem e remontagem.}

Escolher parafusos e peças que permitam ser retirados e recolocados diversas vezes, além de materiais que também sejam resistentes a isso, é importante para que não se danifiquem com facilidade. Isto também ficou claro nos estudos de Reutilização de Estrutura Metálica e da EkoHouse, onde os elementos foram desmontados e remontados.

Padronizar os conectores para ser mais prático o desmonte, assim a mesma ferramenta é utilizada e a pessoa que realiza o desmonte se familiariza melhor com o sistema. No estudo do Ginásio sobre reutilização de estrutura metálica, as peças eram padronizadas e isto facilitou o processo, o mesmo ocorreu na Eko House. 
Reduzir o número de conectores também auxilia o processo, pois diminui o número de ferramentas utilizadas e tornar o desmonte mais eficiente. Além disso, é essencial verificar onde realmente é necessário utilizá-los.

Prever possibilidades de reutilização dos conectores e indicar sua composição, para facilitar futura reciclagem. É importante que os conectores também possam ser reutilizados. A identificação dos materiais, os projetistas podem exigir dos fornecedores.

Numerar as peças contribui para uma futura reutilização e facilita a desmontagem e até remontagem do sistema, se for necessário. Nos estudos da Eko House e Estrutura Metálica as peças foram numeradas para agilizar o processo.

\subsubsection{Diretrizes Gerais para Projeto}

As diretrizes apresentadas neste subitem são gerais para o Projeto para o Desmonte. Assim, não se trata de partes específicas do edifício e sim como um todo. Para Crowther (1999) é necessário compatibilizar os sistemas, dessa maneira é necessário analisar toda a construção.

Outra questão, citada por Crowther (1999) é permitir que os componentes fossem desmontados simultaneamente. Como foi observado nos estudos, isto é difícil de alcançar, mas quanto mais próximo chegar disto, melhor será o resultado. Assim, uma parte não será comprometida para que outra seja desmontada. Normalmente uma parte depende da outra para ser desmontada, como, por exemplo, em uma construção convencional, para retirada ou manutenção do sistema hidráulico, muitas vezes é necessário danificar a alvenaria. Se for possível evitar este tipo de situação, serão obtidos melhores resultados. 
Os sistemas hidráulicos e elétricos não devem ser embutidos, como citam Guy e Shell (2002), Webster e Costello (2005). Dessa maneira, caso seja necessário removê-los ou retirar não danificaria outros elementos construtivos, como ocorre em grande parte das construções convencionais.

Outra questão relacionada, citada por Guy e Shell (2002), seria concentrar os subsistemas elétricos e hidráulicos no mesmo local. Isto foi feito na Eko House e realmente facilitou o processo de desmontagem. Um ponto central onde coloquem os principais elementos hidráulicos e elétricos facilita a manutenção e desmontagem sem danificar outros elementos.

Uma atitude que também contribui para a desmontagem é considerar maneiras simples de desmontar, evitar excesso de ferramentas e força, como mencionado por Romeiro Filho (2010). Esta preocupação estava presente no projeto da Eko House, como confirmado em entrevista com uma das professoras envolvidas no projeto, assim na desmontagem não foi preciso utilizar diversas ferramentas e utilização de muita força. No entanto, ainda foi necessário a utilização de um munck para auxiliar na retirada dos painéis. Mesmo assim, foram utilizadas menos ferramentas e força do que Demolição Convencional ou na Demolição Controlada.

Para Webster e Costello (2005) outra solução é evitar edificações complexas. Grande parte das vezes, quanto mais simples de montar e executar a obra, mais simples será desmontá-la. Quanto maior a variedade de materiais, conexões e sistemas, mais difícil será a desmontagem.

O mesmo autor afirma que utilizar números limitados de diferentes componentes também facilita o processo de desmontagem. Isto também foi observado nos estudos, na Demolição Convencional havia grande variedade de 
materiais e ligações, isto dificultou o processo, enquanto que na Eko House, no Clube de Golfe e no Ginásio, onde os materiais eram mais padronizados e não havia tanta variedade, a desmontagem foi mais eficiente.

Permitir acesso a todas as partes do edifício é essencial, pois além de facilitar a manutenção, também contribui com o desmonte. Principalmente quando é necessário desmontar apenas uma parte ou um sistema do edifício. Os autores Heriqson, Rocha e Sattler (2008), Crowther (1999), Guy e Shell (2002) também citam esta questão como um ponto importante a ser avaliado.

\section{Considerar as dimensões e peso das peças para facilitar o desmonte e} transporte. Peças muito grandes e pesadas dificultam o processo, além de ser necessário utilizar equipamentos mais complexos para o desmonte. Para Heriqson, Rocha e Sattler (2008), Crowther (1999), Guy e Shell (2002) é importante utilizar peças de fácil manuseio, transporte e armazenamento. No caso da Eko House houve grande preocupação com a dimensão das peças, pois o protótipo foi transportado para outro continente, assim foram dimensionados módulos que coubessem em containers. No caso do Clube de Golfe, houve perdas de tijolos e telhas no transporte, e algumas vigas tiveram que utilizar sistemas especiais de transporte. Isto demonstra a importância de considerar esta questão no desenvolvimento do projeto.

A identificação dos materiais, peças e componentes é muito importante para facilitar a desmontagem e reuso, pois é essencial saber qual é o material e sua composição. Isto torna o processo de desmonte e reuso muito mais eficiente. Os materiais deveriam estar identificados pelo menos no memorial descritivo, mas o ideal seria na própria peça. Isto é bastante utilizado nas indústrias automotivas e eletrônicas, também seria muito importante utilizar na construção civil. Os autores 
Crowther (1999), Guy e Shell (2002), Webster e Costello (2005) também ressaltam esta importância.

Identificar os pontos de desmonte é muito importante para evitar confusão. Às vezes, não é necessário desmontar todas as peças, pois podem ser reutilizados elementos compostos. Romeiro Filho (2010) destaca a importância em deixar claro os pontos de desencaixe.

Outra informação importante a considerar é o tempo exato do desmonte, pois quando se ultrapassa este tempo, o processo pode ser tornar mais difícil e caro. Para Go, Wahab et al (2011) é importante considerar relação entre o tempo e custo da desmontagem. Esta questão ficou bastante evidente no estudo sobre Demolição Convencional, pois foram retirados peças e materiais que eram mais rápido e fácil de desmontar, do contrário, não compensava retirar.

Considerar o custo e tempo de desmontagem. Em algumas entrevistas (Desmontagem Programada, Demolição Convencional) foram citadas que apenas a questão sustentável não é suficiente para convencer os clientes a buscarem novas soluções, mas se for possível desmontar com o mesmo tempo e custo, ou até menor, iriam desmontar ao invés de demolir. Os autores Go, Wahab et al (2011) também reforçam a importância em tornar a desmontagem um processo eficaz, evitando gastar muito tempo e dinheiro.

Prever a sequência do desmonte desde o desenvolvimento do projeto contribui para obter melhores resultados. Quando há um plano para desmontar, considerando qual sistema e elementos devem ser retirados inicialmente contribui com a eficiência do processo. Para Go, Wahab et al (2011) é necessário prever a sequência de desmonte, para obter melhores resultados. Nas demolições e desmontagem 
acompanhadas, a sequência do desmonte foi muito importante e foi possível observar que geralmente é na ordem contrária da montagem ou construção.

Também é necessário considerar as diferentes camadas do edifício, como citam os autores Crowther (2005), Heriqson, Rocha e Sattler (2008), Guy e Shell (2002), Webster e Costello (2005). Atualmente, grande parte das edificações é construída com camadas interligadas, além de dificultar todo o desmonte do edifício, também se torna uma barreira quando é necessário desmontar apenas uma parte ou na manutenção. Isto pode ser observado no estudo sobre Demolição Convencional. No entanto, se no desenvolvimento do projeto, analisar como as diferentes camadas do edifício serão compostas e construídas, facilita a demolição. Esta questão também foi abordada no estudo da Eko House, para avaliar qual seria a melhor maneira de construir para futuramente desmontar, sem danificar as diferentes camadas.

Além disso, é importante considerar o porquê, o quê, onde e quando deve ser desmontado, como menciona Crowther (2005). Estas questões ajudam a obter melhores resultados, pois o processo se torna mais racionalizado.

Atualizar informações do projeto, conforme construído também é fundamental. Ter documentos atualizados, como plantas e memoriais, facilita o processo de desmonte e permite que seja bem sucedido, pois se torna possível programar de maneira mais eficiente. Para Webster e Costello (2005) deve-se guardar com segurança o projeto "as built". Assim evita que importantes informações sejam perdidas ao longo dos anos.

Orientar os clientes sobre a importância de considerar o Projeto para o Desmonte e as vantagens que irá obter ao implantar esta ferramenta. Também deixar claro sobre 
os conceitos utilizados e as decisões tomadas. Para Manzini e Vezzoli (2008) os projetistas podem contribuir orientando o cliente e fornecendo opções.

Considerar a ACV em todos os processos da construção, utilização e desmonte do edifício. Para Crowther (2005), Guy e Shell (2002) é necessário considerar os diferentes ciclos-de-vida dos materiais e componentes da edificação. Além disso, analisar o ciclo de material, sistema e subsistema. Programar como pode ser feita a manutenção ou desmonte de sistemas sem danificar outros. Permitir que peças com ciclos de vida diferentes possam ser removidas independentes. Para Go, Wahab et al (2011) isto também tem influencia direta sobre o valor do produto no fim do ciclo de vida.

Analisar quais partes do edifício estão sujeitas a mudanças funcionais, também é importante, pois muitas vezes os edifícios são demolidos porque a função mudou. Se for possível identificar esta questão no desenvolvimento do projeto é possível construir edifício que se adaptem a novas tecnologias e usos sem ser necessária sua demolição. Outra questão a ser observada é considerar a flexibilidade dos elementos que compõem o edifício. Isto facilita o desmonte, além de facilitar a manutenção.

Propor soluções adequadas à tecnologia atual, para que não seja necessário desenvolver novas tecnologias para a desmontagem. Isso ficou evidente no estudo sobre Desmonte Programado, pois foi necessário desenvolver um novo método porque o autor do projeto previa a remoção de uma parede, mas não previu como isto seria feito.

Não transferir problemas de desmontagem para futuras gerações. Muitas vezes, as edificações deverão ser desmontadas nas próximas gerações, mas é 
necessário projetar considerando a tecnologia atual e as possibilidades disponíveis presente. Transferir as soluções para futuras gerações, não contribui para solução das questões levantadas.

Identificar quais são os elementos mais caros do edifício também pode contribuir. Pois se for possível adaptá-los ao novo uso ou tecnologias e mantê-lo em bom estado de conservação, não será necessária a demolição.

Desenvolver um layout simples, padronizado e regular contribui com aumento da vida útil do edifício, manutenção e desmonte, pois também será possível sistematizar melhor o processo de desmontagem. Webster e Costello (2005) afirmam que projetar layout simples e regular resulta em uma desmontagem mais eficiente.

Para Guy e Shell (2002) é necessário considerar a escala humana ao longo do desenvolvimento do projeto. Isto facilita a desmontagem e evita maiores riscos aos operários. Dessa maneira contribui para o manuseio de ferramentas e das peças que serão desmontadas. Até mesmo o armazenamento dos materiais e transporte é melhor. Na construção civil, muitas vezes as peças tem grandes dimensões, mas é importante buscar alternativas tornar o desmonte mais eficiente, como foi feito na Eko House.

Prever possíveis soluções para os resíduos que inevitavelmente serão gerados com o desmonte. Verificar se haverá possibilidade de serem reciclados ou qual será seu destino.

Por fim, repensar o desenvolvimento do projeto e considerar que um dia a edificação chegará ao fim de sua vida útil, seja por deteorização dos materiais, ou fim de sua função. Assim, quando for necessário o desmonte, que seja possível reduzir a 
geração de resíduos, desperdício, impacto ambiental e não se torne um problema para as gerações futuras.

Estas diretrizes foram desenvolvidas a partir de análise da Revisão Bibliográfica e dos Estudos Empíricos, com o objetivo de oferecer orientações para o Projeto para o Desmonte. Assim podem contribuir para obter melhores resultados e evitar os desperdícios e impactos ambientais resultantes das demolições.

Além disso, em anexo, há duas propostas de Checklists que podem auxiliar na aplicação do Projeto para o Desmonte. Além das tabelas há explicações sobre suas aplicações e exemplos de como podem ser utilizadas. 


\section{CONCLUSÕES}

Há uma grande relação entre reduzir o impacto ambiental na construção civil e contribuir para a reutilização e reciclagem de materiais e elementos. Através da revisão bibliográfica, de entrevistas com as pessoas envolvidas nos estudos e observações dos diversos processos, fica evidente que o DFD realmente pode contribir para melhores resultados.

Diversos autores como Gorgolewski (2008), Rocha e Sattler (2008), Couto, Couto e Teixeira (2006), Klohn e Ferreira (2009), Gehin, Zwolinski e Brissaud (2007), Manzini e Vezzoli (2008), Go e Wahab et al. (2011), Crowther (2005), Guy e Shell (2002), Webster e Costello (2005), Heriqson, Rocha e Sattler (2008), Romeiro Filho (2010), Santini e Herman (2010) ressaltam a importância do DFD, pois esta ferramenta contribui com a remoção dos materiais e componentes para futura reutilização e reciclagem.

Como visto na Revisão Bibliográfica e confirmado nos estudo de caso sobre Demolição Convencional, a demolição pode gerar graves consequências, como grande desperdício de materiais e consequentemente, grande impacto ambiental, pois os resíduos, grande parte das vezes, não são tratados e são depositados em aterros sanitários ou lugares ilegais. Os autores Rocha e Sattler (2008), John (2000), Tessaro e Sá et al. (2012) afirmam que a construção civil é uma indústria que consume muita matéria prima e polui o meio ambiente. Portanto, o DFD pode ser mais uma opção para evitar tantos transtornos causados pelo setor.

Além disso, duas questões que foram citadas pelos entrevistados, em todos os estudos empíricos, foram: o custo e o tempo da desmontagem. Muitas vezes os clientes optam pela demolição por ser mais rápido e mais barato. Apenas questões sustentáveis não 
são suficientes para convencer os clientes, ou as empresas, a optarem pela desmontagem.

No entanto quando é possível desmontar rapidamente e obtiver lucro com a revenda dos materiais, eles optam pela desmontagem. Assim é importante buscar soluções que, desde o projeto, seja previsto uma desmontagem rápida, eficiente e com custos reduzidos.

Mesmo quando a reutilização não é programada no projeto inicial, como nos estudos das tulhas de café e do hangar, é possível reaproveitar os materiais e obter bons resultados. No entanto, quando a desmontagem é considerada desde o projeto, como na Eko House, os resultados são muito melhores.

O conceito de reutilização está sendo bem aceito na sociedade, os clientes e usuários, nos dois casos analisados, sobre reutilização de materiais, ficaram muito satisfeito e foi possível obter ótimos resultados. No entanto ainda tem muito a se fazer para conter a alta quantidade de resíduos gerada pelo setor. Mas se for mais bem gerenciada é possível obter ganhos ambientais, sociais e financeiros.

Muitas vezes, como nos casos estudados, as edificações chegam ao fim de sua vida útil devido à mudança de necessidades e do uso e não por depreciação dos materiais ou estrutura. Assim muitos materiais ainda podem ser reaproveitados e reutilizados. Se isso for considerado no projeto, as possibilidades de reutilização são maiores.

Portanto, considerar o ciclo de vida dos materiais e componentes utilizados também é muito importante, pois é possível prever a melhor maneira de desmontar, no melhor momento para que possam ser reutilizados e reaproveitados. 
Os autores Gehin, Zwolinski e Brissaud (2007), Soares, Souza e Pereira (2006), Rocha e Sattler (2009), Edwards e Bennett (2003), Guy e Rocha (2005), Go e Wahab et al. (2011), Lee e Cho et al (2010) falam sobre a importância da ACV dos produtos e buscar fechar o ciclo. Isto é feito através de reutilização e reciclagem e o DFD tem um papel muito importante para manter os materiais e componentes em boas condições após a desmontagem.

Priorizar a reutilização no lugar da reciclagem é fundamental, pois com a reutilização, recursos que seriam utilizados na reciclagem (energia, transporte, matérias-primas) podem ser economizados. O ideal é que o material seja facilmente desmontado e depois recolocado em outra edificação, sem perder suas características originais. Além disso, é essencial repensar o processo de demolição e buscar soluções.

As conexões também são questões muito importantes a ser consideradas no desenvolvimento do projeto, pois como foi visto na revisão bibliográfica e nos estudos de campo, o tipo de ligação influencia diretamente no desmonte. Algumas vezes é impossível separar materiais e sistemas e a única opção é a demolição.

Atualmente é imprescindível projetar considerando as consequências futuras das edificações. No estudo da Desmontagem Programada, fica evidente a necessidade de criar novas tecnologias por falta de programação e previsões do projeto inicial. Foi prevista a ampliação da eclusa, mas para isso seria necessário remover uma parede de concreto maciça, e a maneira de fazer isto não foi considerada. Assim é essencial explorar diversas alternativas ao longo do desenvolvimento do projeto, para que se não se torne um problema para as gerações futuras.

Nos estudos analisados também foi possível observar as diferentes possibilidades de diversos materiais. Em relação ao sistema estrutural, quando se utiliza madeira, é 
possível obter ótimos resultados na reutilização, pois o material pode ser desmontado e remontado sem danificar suas características mecânicas. Além disso, pode ser utilizadas em diversas funções, como mobiliários, caixilhos, elementos decorativos.

As estruturas metálicas, principalmente quando parafusadas ao invés de soldadas, também podem ser desmontadas e remontadas sem perder suas características mecânicas. Além disso, quando utilizado este material, o processo é muito rápido, quando comparados aos outros estudados.

As estruturas em concreto armado são mais complicadas de serem desmontadas, pois precisam de tecnologias e equipamentos mais complexos. Além disso, não é comum reutilizar totalmente as peças (como citado pelo engenheiro da empresa que realiza desmonte programado) e sim triturar o material e transformar em outro produto.

O estudo da Eko House foi o único que considerou a desmontagem desde o projeto inicial, assim foi possível desmontar todos os módulos sem que houvesse perda e desperdícios. Na demolição convencional houve muitas perdas de materiais que foram retirados do local apenas como entulhos. Mesmo no estudo das tulhas de madeira, foi possível reaproveitar grande parte dos materiais, mas ainda sim, muitos materiais foram descartados.

Para Gouvinhas e Romeiro Filho (2010), Heriqson, Rocha e Sattler (2008) o profissional (designer, projetista, arquitetos, engenheiros) podem e devem buscar soluções sustentáveis no desenvolvimento do projeto. Para auxiliar na compreensão e aplicação dos conceitos do Projeto para o Desmonte, pelos profissionais envolvidos, foram criadas as diretrizes e os checklists, apresentados no capítulo anterior. 
Com a análise da Revisão Bibliográfica e dos Estudos Empíricos foi possível desenvolver as diretrizes, assim o conceito do Projeto para o Desmonte pode ser compreendido com mais clareza e aplicado de forma mais consistente. A partir das diretrizes foram desenvolvidos os checklist que também contribuem com 0 desenvolvimento do projeto e permite pontuações para melhor análise das escolhas do sistema estrutural, materiais, componentes e conexões.

Assim, pode-se concluir que quando o projeto considera a reutilização de materiais de outras construções é possível obter bons resultados, no entanto o ideal seria que todas as edificações tivessem o Projeto para Desmontagem, para obter melhor aproveitamento dos materiais e componentes, no futuro. Dessa maneira o desperdício e resíduos da construção civil seriam amenizados, o que contribuiria para o desenvolvimento sustentável.

\subsection{Sugestões para futuros trabalhos}

- Pesquisar sobre maneiras de identificar os materiais na construção civil. Nas edificações são utilizados diversos materiais de diversos fornecedores, como não há identificação do material específico utilizado, muitas vezes pode atrapalhar 0 processo de reaproveitamento.

- Pesquisar diversos sistemas de encaixes e conexões para que o processo de desmontagem se torne mais rápido e econômico, sem danificar as peças.

- Pesquisas sobre diversos materiais e possibilidades de reutilização. Quais e como diversos materiais podem ser reaproveitados, quais as vantagens e barreira para isso. 


\section{REFERÊNCIAS BIBLIOGRÁFICAS}

ABNT. NBR. ISO. ASSOCIAÇÃO BRASILEIRA DE NORMAS TÉCNICAS. NBR ISSO 14040. Avaliação do Ciclo de Vida: princípios e estrutura. Rio de Janeiro, 2001. 10 p. ABNT. NBR. ISO. ASSOCIAÇÃO BRASILEIRA DE NORMAS TÉCNICAS NBR ISSO 14044. Gestão Ambiental - Avaliação do Ciclo de Vida: requisitos e orientações. Rio de Janeiro, 2009. $46 \mathrm{p}$.

ABNT. ASSOCIAÇÃO BRASILEIRA DE NORMAS TÉCNICAS. NBR 15575/2013: Edifícios Habitacionais - desempenhos. Rio de Janeiro, 2013.

ABNT> ASSOCIAÇÃO BRASILEIRA DE NORMAS TÉCNICAS. NBR 7190/1997: Projetos de estrutura de madeira. Rio de Janeiro, 1997.

ABRAHAM, M. A.(edit); SHELDON R. Sustainability Science and Engineering: defining principles. Toledo, OH, EUA: ELSEVIER, 2006. v.1. 518 p.

ABREU, G. C. $4^{\circ}$ Simpósio Brasileiro de Construção Sustentável. A Sustentabilidade da Indústria do Aço. São Paulo, ago. 2011. Disponível em: < http://www.sbcs.net.br/images/palestras/0408_palestras/4_guilherme_correa.pdf > . Acesso em: nov. 2011.

AFLALO, M. (Org.). Madeira como estrutura: a história do ITA. São Paulo: Paralaxe, 2005.

ALVES, J. E. D. Gente: um tabu a ser enfrentado. VEJA. São Paulo: ABRIL: 4 p. 2012.

AMERICAN WOOD CONCIL. Details for conventional Wood Frame Construction. Disponível em: < http://www.awc.org/pdf/wcd1-300.pdf>. Acesso em: 20 jun. 2011. AMOÊDA, R. P. C. Concepção para a desconstrução: abordagem emergética à avaliação da efetividade da desconstrução. Portugal, 2009. Tese de Doutorado Universidade do Minho. 
ANDERE, P. A. R.; SANTOS, H.I. Disposição Final de Resíduos da Construção Civil - Estudo de Caso. Disponível em <www.ucg.com.br>. Acesso em 20/05/2010.

ÂNGULO, S.C. Variabilidade de Agregados Graúdos de Resíduos de Construção e Demolição Reciclados. São Paulo 2000. Escola Politécnica da Universidade de São Paulo, 2000 (Dissertação de Mestrado).

BARKOKÉBAS JUNIOR, B. et al. Análise das condições dos ambientes de trabalho e das práticas adotadas em um canteiro de obras de demolição. XII Encontro Nacional de Tecnologia do Ambiente Construído. Fortaleza-CE: 10 p. 2008.

BELLEN, H.M.; Indicadores de Sustentabilidade: uma análise comparativa. Editora FGV: Rio de Janeiro, 2006 (pg.23-39).

BHAMRA, T.; HON, B. (Edit.). Design and manufacture for sustainable development 2004. Trowbridge, Wiltshire, Reino Unido: The Cromwell Press, 2004. 263p.

BLANCO, M.; Norma de Desempenho já esta valendo, de 12 de maio de 2010. Disponível em <http://www.piniweb.com.br/construcao/gestao/artigo173861-2.asp>. Acesso em 06/07/2010.

BREWER, G.; MOONEY, J. A best practice policy for recycling and reuse in building. Proceedings of the Institution of Civil Engineers-Engineering Sustainability, v. 161 , n. 3, p. 173-180, Sep 2008. ISSN 1478-4629. Disponível em: < <Go to ISI > ://WOS:000270356200006 >.

BUTTLER, A.M.; CORRÊA, M.R.S.; RAMALHOS, M.A. Blocos de alvenaria estrutura produzidos com agregados reciclados de concreto. Belo Horizonte, 2007. Universidade UMEC.

CÂMARA BRASILEIRA DA INDÚSTRIA DA CONSTRUÇÃO (CBIC). Consumo Mensal de Cimento. In:Sindicato Nacional da Indústria do Cimento (SNIC). 2010. Disponível: <http://www.cbicdados.com.br>. Acesso em: 21 ago. 2011.

CANADIAN WOOD CONCIL. Conections. Disponível em: <http://www.cwc.ca/Products/Connections/?Language=EN> Acesso em: 23 jun. 2011. 
CARNEIRO, F. P. et al. Análise da geração de resíduos sólidos em uma obra de demolição na cidade de Recife Estudo de Caso. XI Encontro Nacional de Tecnologia no Ambiente Construído. Florianópolis: 10 p. 2006.

CASSA, J.C.S.; CARNEIRO, A.P.;CRUM, IRINEU A.S.; Reciclagem de entulho para a produção de materiais de construção. Salvador, 2001 - EDUFBA

CATANIA, C.A.; LA MANTIA, F.P. Reduction and reuse of waste - design and newgeneration plastics. In: In: BHAMRA, T.; HON, B. (Edit.). Design and manufacture for sustainable development. Trowbridge, Wiltshire, Reino Unido: The Cromwell Press, 2004. 263p.

CIB, UNEP-IETC. Agenda 21 for Sustainable Constructions in Developing Countries. Pretoria, África do Sul: CSIR Building and Construction Technology. [Documento para Discussão], 2002.

CBIC. Construção civil: análises e perspectivas, dez. 2010. Disponível em: <http://www.cbicdados.com.br/files/textos/063.pdf>. Acesso em: 03 set. 2011.

CHAHUD, E.; ALCÂNTRA, P.L.; LAHR, F.A.R. Os resíduos para a construção civil. Belo Horizonte, 2007. Universidade FUMEC

CONAMA Resolução n. 307 do CONSELHO NACIONAL DO MEIO AMBIENTE, de 05 de julho de 2002. Disponível em <http://www.mma.gov.br/port/conama/res/res02/res30702.html>. Acesso em $16 / 05 / 2010$.

CONFORTO, E. C; AMARA, D.C. Evaluating an agile method for planning and controlling innovative projects. Project Management Journal, 2008.

CORBELLA, Oscar e YANNAS, Simos. Em Busca de Uma Arquitetura Sustentável Para Os Trópicos - Conforto Ambiental. 1. ed. Rio de Janeiro: Revan Ltda, 2003.

CORSINI, R. Desmontagem Controlada. TÉCHNE. São Paulo: PINI: 5 p. 2012.

COUTO, A. B.; COUTO, J. P.; TEIXEIRA, J. C. Desconstrução - Uma Ferramenta para Sustentabilidade na Construção. In: NUTAU .2006, São Paulo. 
CROWTHER, P. Design for Disassembly - Themes and Principles. BDP Environment Design Guide, 2005.

CROWTHER, P. Design for Disassembly to Recover Embodied Energy. PLEA. Austrália: 6 p. 1999

CYBIS, L.F.; SANTOS, C.V.J. Análise do Ciclo de Vida (ACV) Aplicada à Indústria da Construção Civil: estudo de caso. XXVII Congresso Interamericano de Engenharia Sanitária e Ambiental. Porto Alegre, dez.2010.

DEGANI, C. M.; CARDOSO, F. F. A sustentabilidade ao longo do ciclo de vida de edifícios: a importância da etapa de projeto arquitetônico. In: NUTAU. 2002, São Paulo.

DEGANI, C. M.; CARDOSO, F. F. A Sustentabilidade ao Longo do Ciclo de Vida de Edifícios: A Importância da Etapa de Projeto Arquitetônico. São Paulo 2002. Escola Politécnica da Universidade de São Paulo.

DURMISEVIC, E.; NOORT, N. Re-Use Potential of Steel in Building Construction. Deconstruction and Materials Reuse, CIB, Flórida, p. 352-361, 2003.

EDWARDS, S.; BENNETT. Construction products and life-cycle thinking. UNEP Industry and Environment, Reino Unido, p. 57-65, abr-set 2003.

FABRICIO, M. M. Projeto Simultâneo na construção de edifícios. 2002. $329 f$. Tese (Doutorado em Engenharia) - Escola Politécnica da Universidade de São Paulo, São Paulo, 2002.

FABRICIO, M. M. O arquiteto e o coordenador e projetos. Pós, São Paulo, n.22, p. 2650, dezembro, 2008.

FORMOSO, C. T. et al. Material waste in building industry: main causes and prevention. Journal of Construction Engineering and Management, vol. 128, no. 4, p. 316325, ago. 2002.

FORMOSO, C. T. ; SOIBELMAN, L. ; DE CESARE, C. M. ; ISATTO, E. L. Material Waste in Building Industry: main causes and prevention. Journal of Construction Engineering and Management, New York, v. 128, n. 4, p. 316-325, 2002. 
GATTI, J.B.; QUEIROZ, G.C.; GARCIA, E.E.C. Recycling of Aluminum Can in Terms of Life Cycle Inventory (LCI). Int J LCA 13 (3) 219-225.

GEHIN, A.; SWOLINSKI, P.; BRISSAUD, D. A tool to implement sustainable end-of-life strategies in the product development phase. Journal of Cleaner Production, França, v.16, p. 566-576, 2008.

GIL, Antônio Carlos. Como Elaborar Projetos de Pesquisa. 4.ed. São Paulo: Atlas S.A.,2002.

GITAHY, Maria Lucia Caira e PEREIRA, Paulo César Xavier. O Complexo Industrial da Construção e A Habitação Econômica Moderna 1930-1964. 1. ed. São Carlos: Rima,2002.

GO, T. F. et al. Disassemblability of end-of-life vehicle: a critical review of evaluation methods. Journal of Cleaner Production, v.19, p. 1536-1546, set. 2011.

GOUVINHAS, R.P; ROMEIRO Filho, E. Projeto para o meio ambiente. In: ROMEIRO FILHO, E. (Coord.). Projeto do Produto. Rio de Janeiro: Elsevier, 2010. Cap. 14.

GORGOLEWSKI, M. Designing with reused building components: some challenges, Building research \& Information, 36:2, 175-188, 2008.

GUINÉE, J. et al. Life Cycle Assessment: Past, Present and Future. Environmental Science \& Technology, v. 45, p. 7, 2011.

GUY, B.; ROCHA, C. A building lifecycle model based on a design for deconstructions approach. In: SIMPÓSIO BRASILEIRO DE GESTÃO E ECONOMIA DA CONSTRUÇÃO, IV., 2005, Porto Alegre.

HENRIQSON, J.; ROCHA, C.; SATTLER, M. Análise e Descrição do Processo de Demolição de Edificações. ENTAC. FORTALEZA. 12: 10 p. 2008.

INO, A. Projeto e Construção em Madeira e Terra. In: ELECS, 2009, Recife. Mini-curso. p. 67.

INSTITUTO DE AÇO DO BRASIL. Relatório de Sustentabilidade. 2010. Disponível em: <http://www.acobrasil.org.br/site/portugues/sustentabilidade/relatorio.asp>. Acesso em: nov. 2011. 
Guy, B.; Shell, S. Design for Deconstruction and Materials Reuse. CIB Publication, 272, 20p., Rotterdam (Netherlands), 2002. Disponível em: < http://www.irbnet.de/daten/iconda/CIB951.pdf>. Acesso em: fev. 2012.

JENSEN, P. A. Inclusive briefing and user involvement: case study of a media centre in denmark. Architectural Engineering and Design Management, vol.7, p.38-49, 2011.

JIMENEZ, G.; ARINI, J. Quem vai pagar a conta? VEJA. São Paulo: ed. ABRIL: 4 p. 2012.

JOHN, V. M. Reciclagem de resíduos na construção civil: contribuição à metodologia de pesquisa e desenvolvimento. 2000. 113p. Tese (Livre Docência) Escola Politécnica da Universidade de São Paulo, Departamento de Engenharia Civil, São Paulo, 2000.

JOHN, V. M.; ANGULO, S. C. Metodologia para desenvolvimento de reciclagem de resíduos. In: VANDERLEY MOACYR JOHN; JANAIDE CAVALCANTE ROCHA. (Org.). UTILIZAÇÃO DE RESÍDUOS NA CONSTRUÇÃO HABITACIONAL. 1 ed. PORTO ALEGRE: ANTAC, 2003, v. 4, p. 8-71.

KAREL, M. (Edit); Sustainable Development for Engineers: a handbook and resource guide. Reino Unido: Greenleaf Publishing Ltd, 2006.

KEOLEIAN, G.A.; SPITZLEY, D.V.; Life Cycle Based Sustainability Metrics. In: ABRAHAM, M. A.(edit); SHELDON R. Sustainability Science and Engineering: defining principles. Toledo, OH, EUA: ELSEVIER, 2006. cap.7 p. 127-159.

KLOHN, S. C.; FERREIRA, N. F. Sustentabilidade e design para desmontagem - estudo de caso. IN: CONGRESSO INTERNACIONAL DE PESQUISA EM DESIGN, 5. 2009, Bauru.

KLOHN, S. C. Ecodesign: desenvolvimento de pictogramas para o auxílio da desmontagem de produtos. 2009. 79f. Dissertação (Mestrado em Design) Universidade Federa do Rio Grande do Sul. Escola de Engenharia \& Faculdade de Arquitetura, Porto Alegre, 2009. 
KUO, T.; HUANG, S.H.; ZHANG,H. Design for manufacture and design for 'X': concepts, applications, and perspectives. Computer \& Industrial Engineering, n. 41, p. 241260, mai. 2001.

LEE, H. B.; CHO, N. W.; HONG, Y. S. A hierarchical end-of-life decision model for determining the economic levels of remanufacturing and disassembly under environmental regulations. Journal of Cleaner Production, v. 18, n. 13, p. 12761283, Sep 2010. ISSN 0959-6526. Disponível em: < <Go to ISI>://WOS:000280376000005 >.

LORDÊLO, P.M.; EVANGELISTA, P.P.A.; FERRAZ,T.G.A.Gestão de resíduos na construção civil: redução, reutilização e reciclagem. Salvador, 2004 - SENAI

LUDOLF, M.L. Especificação, prática simplificada, padronização. In: Boletim de IPT. São Paulo, LEM, n.4, 1931.

MAGENT, C.S. et al. A design process evaluation method for sustainable buildings. Architectural Engineering and Design Management, vol.5, p.62-74, 2009.

MANZINI, E.; VEZZOLI; C. O Desenvolvimento de Produtos Sustentável. 1.ed 2 reimpr.: São Paulo: Editora da Universidade de São Paulo, 2008. 367p.

MARTINS, A. Ita: da pedra a madeira serrada. In: AFLALO, M. (Org.). Madeira como estrutura: a história do ITA. São Paulo: Paralaxe, 2005.

MEIRA, F.A.; MELO A.B.; Resíduos da Construção Civil: um olhar a partir do diálogo com profissionais envolvidos no processo de produção da arquitetura. ENANPARQ II Encontro da Associação Nacional de Pesquisa e Pós-graduação em Arquitetura e Urbanismo, Natal, 21p. 2012.

MATOS, D.A. Logística reversa, balanced scorecard e os programs de reciclagem de recursos da USP/São Carlos e da UFSCar. São Carlos, 2007. Tese (mestrado) Escola de Engenharia de São Carlos

MATOS, G.; WAGNER, L. Consumption of Materials in the United States 19001995. US Geological Survey. [1999] 9p. 
MOLINA, J. C.; CALIL JUNIOR, C. Sistema construtivo em Wood Frame para casas de madeira. Semina: Ciências Exatas e Tecnológicas, Londrina, v.3, n.2, p.143 - 156, jul. /dez. 2010.

NUNES, L.; MAHLER, C.; VALLE R. Reverse logistics in the Brazilian construction industry. Journal of Environmental Management 90: 3717-3720, 2009.

OLIVEIRA, L.A.; WAELKENS, A.C.; MITIDIERI FILHO, C.V. Sistemas construtivos tipo light steel frame para unidades habitacionais - aspectos relativos à durabilidade. Téchne, São Paulo; ed.146, ano 19, p.78-83, nov. 2011.

PAIVA, P. A.; RIBEIRO, M.S. A Reciclagem na Construção Civil: como economia de custos. Disponível em <www.facef.br>. Acesso em 15/05/2010.

PEREIRA, Fernando Oscar Ruttkay (Edit.). Construção e Meio Ambiente. Porto Alegre: ANTAC, 2006. Cap. 4, p.96-127. (Coletânea Habitare, v. 7).

PINTO, T. P. Metodologia para a gestão diferenciada de resíduos sólidos da construção urbana. São Paulo, 1999. Tese (doutorado) - Escola Politécnica, Universidade de São Paulo.

PFEIL,W. Estruturas de Madeira: dimensionamento segundo as normas brasileiras NB 11 e os modernos critérios das normas alemãs e americanas. $3^{\circ}$ ed. Rio de Janeiro: LTC - Livros Técnicos e Científicos Editora S.A., 1984. 321p.

RAZAZ, Z. Design for dismantling strategies. Journal of Building Appraisal, n.6, p.49-6, mar.2010. Disponível em: <http://www.palgravejournals.com/jba/journal/v6/n1/full/jba20109a.html>. Acesso em: 09 set. 2011.

ROCHA, C. G. Proposição de Diretrizes para Ampliação do Reuso de Componentes de Edificações. 2008. 172 (Mestre). Engenharia Civil, UFRGS, Porto Alegre.

ROCHA, C. G.; SATTLER, M. A. A discussion on the reuse of building components in Brazil: An analysis of major social, economical and legal factors. Resources, Conservation and Recycling, v. 54, p. 9, 2009. 
ROCHA, J. C. (Edit); JOHN V. M. (Edit); Utilização de resíduos na construção habitacional. Porto Alegre: ANTAC, 2003. - (Coleção Habitare, v. 4). 272 p.

ROMEIRO FIlHO, E. (Coord.). Projeto do Produto. Rio de Janeiro: Elsevier, 2010. 408p.

SACCO, M. F.; STAMATO, G. C. Light wood frame - construções com estrutura leve de madeira. Revista Téchne, São Paulo, ano 17, ed. 148, p. 48-53, jul. 2009. Disponível em: <http://www.revistatechne.com.br/engenharia-civil/140/imprime117396.asp>. Acesso em: 20 jun. 2011.

SACHS, I; Caminhos para o Desenvolvimento Sustentável. Garamond: Rio de Janeiro, 2002 (pg.47-88).

SACHS, W; Justiça num Mundo Frágil: memorando para a cúpula mundial sobre o desenvolvimento sustentável. Fundação Heinrich Böll: Rio de Janeiro, 2002.

SÁNCHEZ, Luis Enrique. Avaliação de impacto ambiental: conceitos e métodos. São Paulo: Oficina de Textos, 2008.

SANTINI, A. et al. Assessment of Ecodesign potential in reaching new recycling targets. Resources Conservation and Recycling, v. 54, n. 12, p. 1128-1134, Oct 2010. ISSN 0921-3449. Disponível em: < <Go to ISI >://WOS:000281752400012 >.

SERRADOR, A. E. Sustentabilidade em arquitetura: referências para projeto. 2008.267f. Dissertação (Mestrado em Arquitetura e Urbanismo) - Departamento de Arquitetura e Urbanismo da Escola de Engenharia de São Carlos, Universidade de São Paulo, São Carlos, 2008.

SMERALDI, Roberto; VERÍSSIMO, José Oliveira. Acertando o alvo: consumo de madeira no mercado interno brasileiro e promoção da certificação florestal. São Paulo: Amigos da Terra - Piracicaba, SP: IMAFLORA; Belém, PA: IMAZON, 1999.

SMITH, R.C. Materials of construction. McGraw, Tokyo, 1973 ( $2^{\circ}$ edition). PP.Xi

SOARES, S. R.; SOUZA, D.M.; PEREIRA, S. W. A avaliação do ciclo de vida no contexto da construção civil. In: SATLER, M. A.; PEREIRA, F.O.R. Coletânea Habitare, v.7. 296 p. Rio de Janeiro, 2000. Disponível em 
<http://habitare.infohab.org.br/ArquivosConteudo/ct_7_cap4.pdf>. Acesso em 20/03/2012.

SOUZA, U. E. L.; PALIARI; L.C.; AGOPYAN,V. O custo do desperdício de materiais nos canteiros de obras. Qualidade na construção. São Paulo : SINDUSCON, n²1 Anolli, 1999.p.64-67

SINAT (Sistema Nacional de Avaliações Técnicas), Diretrizes para Avaliação Técnica de Produtos. Disponível em (http://www4.cidades.gov.br/pbaph/projetos sinat.php>. Acesso em 20/08/2010.

SUCCAR, B. Building information modeling framework: A research and delivery foundation for industry stakeholders. Automation in Construction , vol. 18, p. 357375, 2009.

TESSARO, A. B.; SÁ, J. S.; SCREMIN, L. B. Quantificação e classificação dos resíduos procedentes da construção civl e demolição no município de Pelotas, RS. Ambiente Construído, v. 12, n. 2, p. 10, 2012.

THORMARK, C. Recycling Potential and Design for Disassembly in Building. Lund, Suécia: KFS AB. 104p.

VEIGA, J.E.; Desenvolvimento sustentável: o desafio do século XXI. Garamond: Rio de Janeiro, 2010 (pg.187-209).

WEBSTER, M. D., COSTELLO, D. T. Designing structural systems for deconstruction: How to extend a new building's useful life and prevent it from going to waste when the end finally comes. Greenbuild, Conference, Atlanta, GA November, 2005

WESTPHALEN, A. L. Faturamento de materiais cresce 12\%. Valor Econômico, São Paulo, jan.2011. Disponível em: <http://www.abramat.org.br/cont/cont_detalhe.asp?cod=2304>. acesso em 03 ago. 2011.

WINES, James. Green Architecture, ed. China: Tashen GmbH, 2008. 
YIN, R. K. Estudo de Caso: planejamento e métodos. 3. Porto Alegre: Bookman, 2005. 212

YUBA, A. N. Análise da pluridimensionalidade da sustentabilidade da cadeia produtiva de componentes construtivos de madeira de plantios florestais. 213f. Tese (Doutorado em Ciências da Engenharia Ambiental) - Escola de Engenharia de São Carlos, Universidade de São Paulo, São Carlos, 2005. 


\section{ANEXOS}

\section{A. Entrevista com Arquiteto 01}

Entrevista realizada no dia 31 de maio de 2011, em seu escritório, em São Carlos, SP, sobre reutilização de materiais.

Observações:

No clube Golfe em São Carlos, foram reaproveitadas madeiras provenientes de madeiras de Tulhas de café compradas de fazendeiros. Foram utilizadas peças 40x50 / 60 de peroba. A montagem da estrutura foi feita através de encaixes e prego. Não houve tratamento químico, apenas raspagem e retirada dos pregos e parafusos. $\mathrm{Na}$ construção central foram reaproveitados tijolos e telhas. Nas alas laterais foram utilizados novos tijolos e telhas. Algumas peças de madeira tiveram que ser compradas para completar a estrutura.

Na residência do arquiteto também houve reaproveitamento de materiais. Foram reaproveitados vidros de carros antigos, comprados e transformados em caixilhos. Foi feita uma parede com tijolos reutilizados. Uma viga de madeira foi transformada em caixilhos. Não houve tratamento, apenas envernizou. Reutilização de pedra arenito São Carlos, era piso em outra residência e foi retirado, recuperado e transformado em pilar, fixado com argamassa.

Algumas vezes não vale a pena restaurar. Se for considerado o tempo e o orçamento, muitas vezes não compensa. Compensa se a pessoa realmente fizer questão de manter o material. O custo da mão de obra pode ser alto, devido ao trabalho artesal e minucioso.

Existem empresas que vendem materiais e componentes para serem reutilizados, no entanto, acaba saindo mais caro, pois além de comprar o material e necessário tratá-lo e deixá-lo em condições de reutilização. 


\section{Entrevista com o administrador geral do clube de Golfe}

Entrevista realizada em 31 de maio de 2011, no Clube de Golfe em São Carlos - SP.

Observações sobre a entrevista:

As madeiras são provenientes de 5 tulhas de café de fazendeiros que estavam demolindo-as e queriam aproveitar o material de alguma maneira. Foram reaproveitados os tijolos, as madeiras e as telhas. Os maquinários utilizados para a produção do café foram restaurados e encaminhados para um museu, localizado na Fazenda São Miguel.

As madeiras são peroba rosa. Não houve perda de madeira pois pode ser reaproveitada de várias maneiras. Se não pudessem ser utilizadas na estrutura, era usada para fazer o mobiliário ou outros detalhes da construção. Não houve nenhum tratamento químico. Apenas raspagem e retirada de antigos pregos.

As características das madeiras foram mantidas, caso houvesse furos de parafusos, ou outros "defeitos" não tentaram disfarçar. A construção está próxima de completar quatro anos e não apresentou nenhum problema em relação a cupins ou outras pestes. Até hoje, nenhuma peça teve que ser trocada.

A união da estrutura de madeira com a alvenaria de tijolos e argamassa funcionou bem, pois não há fissuras, nem frestas. As uniões da peças foram feitas através de encaixes e parafusos.

A mão de obra utilizada, foram carpinteiros especializados. É o mesmo desde o dia em que começou a obra. Ele realiza um trabalho minucioso de buscar o melhor aproveitamento de cada peça de madeira.

Muitos tijolos puderam ser reaproveitados, pois foram assentados, nas tulhas, com barro, assim ficou mais fácil separar. Muitas telhas foram quebradas, mas uma boa parte pode ser reaproveitada. Alguns pilares chegam a ter $13 \mathrm{~m}$ de comprimento. 


\section{B. Segunda entrevista com o Arquiteto 01}

Entrevista realizada no dia 17 de agosto de 2011, no escritório do arquiteto, em São Carlos, SP, sobre o projeto do Clube de Golfe.

L: Como foi feito o processo do projeto? Partiu do cliente querer realizar este tipo de material?

JM: Houve uma confusão no processo, pois o projeto iniciou comigo, depois foi para outro arquiteto, depois voltou. Logo no início eu havia proposto que se fizesse o edifício com estrutura de madeira.

L: Ainda não havia a idéia de se reaproveitar o material?

JM: Não. Quando o projeto retornou a mim, na segunda vez, eles (clientes) me avisaram que haviam comprado umas tulhas velhas que o pessoal estava vendendo que tinha muita madeira e eles tinham acabado de comprar uma outra, então eu fui lá ver inclusive, dei uma olhada na madeira, era muita madeira mesmo, madeira em perfeito estado. Tinha os locais dos encaixes, algumas estavam com caruchos e cupins, mas dava para usar, e agente partiu disso aí. Primeira coisa, nós vamos usar madeira. Então eu pensei numa situação no projeto, e acho que a idéia sai um pouco, se não me engano, tem uma casa do Lúcio Costa, que eu gosto muito, que tinha alguma coisa, vamos dizer assim, alguma referência...

L: Qual casa que é?

JM: Ai, eu não me lembro, uma casa se eu não me engano...

L: Com estrutura de madeira?

JM: Sim. De um poeta, amazonense, se eu não me engano, Tiago... Eu não me lembro...

L: Depois eu procuro...

JM: E tem uma referência de um edifício de um italiano, eu esqueço o nome... depois eu vejo aqui e te falo...

L: Tá 
JM: Eu tinha visto uma casa dele, um palácio dele lá e que tinha essa idéia da horizontalidade com alguma coisa que subia e isso me remetia também a essa casa do Lúcio. Só que a casa do Lúcio de um lado tinha uma parte mais baixa e do outro lado mais alta e eu trabalhei nesse sentido. A primeira idéia foi uma coisa assim, foi lá no começo, eu lancei uma idéia em que era alguma coisa horizontal e um elemento mais alto no meio, que tinha pouquíssima coisa a ver com esse projeto, não tinha isso aqui (apontou para a maquete) num existia essa parte interna, era só aqui... Aí quando me pediram para fazer o projeto, eu comecei a trabalhar, a gente foi visitar uns locais de golfe, verificar sedes e tal e voltei a trabalhar com essa mesma idéia de horizontalidade. Eu também gosto muito de trabalhar com modulação, agente soltou uma modulação de madeira e soltou, ela qui, a modulação tem alguma coisa a ver aqui no meio, eu não lembro direito como é que era também e aqui eu trabalhei com "submuro", depois multipliquei na vertical também e agente lançou uma idéia e tinha alguns problemas, aqui em cima, mais ou menos, tava um pouco diferente, era uma vigas um pouco diferente, mas já tinha a idéia de ter o quadrado e depois virar. Só que a maneira com que você juntava as vigas era diferente. E eu apresentei essa primeira idéia e eles gostaram.

L: E essa modulação teve a ver com os tamanhos das peças disponíveis, chegou a fazer um levantamento?

JM: Eram peças grande, então eu achei que ia dar, mais ou menos, essa mudulação que a gente usou, em torno de $6 \mathrm{~m}$ e lá tinha muita peça de $60 \mathrm{~cm}$. Eu achei até inclusive na época, eu não entendo muito da madeira, da resistência, mas eu sei que a peça passava. Daí quando lancei a primeira idéia e eles aprovassem, eu sugeri de um lado a parte que era vestiário e do outra lado uma pequena cozinha, eles tinham pedido uma lanchonete, num ia ter restaurante, fizemos uma coisa pequena com dois banheiros social e uma área social. E eles, no meio do processo mudaram, vai ser um restaurante. O projeto estava pronto. Mas tudo bem, fizemos uma adaptação. Já estava até construído umas partes e teve que derrubar algumas paredes. Aí eu pedi que eles me arranjassem alguém de madeira, que trabalhasse com madeira e lá na USP me indicaram três pessoas, aí foi tirado o orçamento, aí um engenheiro que mexe com madeira, aqui em São Carlos, o Henrique Pastel, ele pegou e a gente trabalhou junto e praticamente o projeto foi desenvolvendo e a agente ia discutindo as questões, como é que a gente resolvia os detalhes. Foi pego um livro, inclusive a Akemi que me 
arranjou um livro Japonês elementos de encaixe. A gente usou muito aqui, esse livro rodou... Nós colocamos também um engenheiro de concreto porque aqui resolveu que aqui (maquete) tinha que ter umas vigotas de concreto porque achamos que a madeira poderia dar algum problema. Então tem uma séria de lugares que tem a madeira e uma vigota de concreto para segurar e travar a alvenaria. E a gente desenvolveu todo o projeto praticamente. Isto aqui ó (maquete) foi resolvido, essa ultima viga aqui de fora foi resolvida na maquete. A gente testava, 'não vamos, 'não assim não dá', 'e se a gente colocar uma vigota aqui', 'será que passa toda aquela'... e acabou dando certo

\section{L: Foi em conjunto com o projeto?}

JM: foi em conjunto com o projeto. A maquete, a gente mudava a maquete, tinham duas arquitetas aqui montando a maquete. Também tinha uma pessoa para trabalhar o conforto térmico. O edifício não tem ar condicionado e eles exigiam ar condicionado. A maior face dele é norte, ele tem entradas e saídas de ventilação. Tinha aqui em cima, o que eles não fizeram na obra um sistema de captação da luz. O sol bateria aqui, que teria uma prancha horizontal no meio do caixilho, pintada de branco, que o sol bateria nela e jogaria aqui dentro, o forro é branco, ai ela refletiria aqui para baixo.

Que mais que tinha? Isso aqui é todo um sisteminha de ventilação de saída de ar quente. Isso aqui que foi estudado e depois foi suprimido era o sisteminha de travamento da estrutura, depois não precisou. No começa eles achavam que ia precisar e pediram para colocar. Seria um travamento e a gente até estudou um elemento para esse travamento não ficar aí no meio do caminho. Ai acharam que não ia precisar mais, então a gente tirou.

L: A entrada e saída de ar (lado dos sanitários) mantém?

JM: Sim, mantém.

L: Algumas madeira tiveram que ser compradas não é?

JM; Sim, as compradas foram essas aqui (modulo central). Alguns caibros também tiveram que ser comprados.

L: o tom tom (gerente) comentou que duas delas são originais? 
JM: Não... ah, parece que algumas delas são.

L: Inicialmente foi falado da madeira, do programa e a partir disso começaram...

JM: Não, teve um golfista que fez o campo. É bom você pegar o nome dele com o tom-tom também. Ricardo, eu não me lembro, Ricardo...

L: Tudo bem

JM: A gente chegou a discutir o programa com ele.

L: Sim, o projeto do campo de golfe é algo muito específico, não é?

JM: Precisava ter. Porque lá no começo a gente já tinha rabiscado alguma coisa e depois eu discuti com ele o que precisava ter. Principalmente esta ala aqui, que é a ala dos vestiários.

L: O marceneiro que participou da construção entrou em que fase?

JM: Depois do projeto. Foi bastante interessante porque esta parte aqui, esta estrutura aqui, por exemplo, ele montou ela todinha no chão, deixou ela montada no chão e depois com uma grua, foram suspendendo parte por parte. Eles pegavam uma parte e colocava, depois pegava outra parte e colocava e foram estendendo ela por partes.

L: O senhor tem fotos da obra?

LM: Eu precisaria procurar

L: Eu sei, depois a gente da uma olhada.

L: E o senhor comentou que em algumas madeiras tinham bichos...

JM: ah sim, em uma série de pilares

L: Tratamento químico não foi feito né?

JM: Foi feito um tratamento, certo, e deixou como estava.

L: tirou os bichos que tinha... 
JM: Mas já não tinha mais. Quando ela veio, eles já tinham feito algum tratamento. 0 que a gente fez foi: deixamos aquilo como estava mesmo, ou foi passado algum remédio, ou alguma coisa lá. Impermeabilizado. Que aqui em São Carlos dá muito cupim.

L: O que eu achei bonito é que logo na entrada que estão assim, tipo, parece que são os mais danificados, mas ficou bem legal.

JM: É, naquela entrada. Tem uns aqui também... Tem um lá, que aqui no pé que perdeu uma parte que o cupim já tinha comido...

L: Mas isso que dá a graça, né?

JM: Sim...Foi pedido aquele aparelho para levantar ele do chão. Dá melhor proteção, foi coisa do Alvar mesmo, ele que pediu para deixar mais alto, ele que tinha visto um detalhe uma vez muito interessante e ele arrumou uma revista que tinha aquele detalhe e falou que queria mais ou menos aquilo, que queria levantar e a gente pensou naquele elemento.

L: Foi o engenheiro que sugeriu?

JM: Não, que sugeriu foi o Alvar que é dono.

L: Então ele também estava envolvido?

JM: Tava.

L: Durante o desenvolvimento do projeto, o que o senhor considera que seja mais diferente que um outro projeto de alvenaria, o que não teve a estrutura como conceito e tem outras coisas como partido. O senhor acha que o fato de ter a madeira reutilizada, mudou alguma coisa no processo do projeto?

JM: Não. A gente sabia que as madeiras de alguma forma, a maior parte das madeiras que a gente tinha lá, dava para ser utilizada. Os pilares, praticamente, todos os pilares pequenos, a maioria deles saíram de lá. Uma série de vigas saíram de lá também. 0 'estovo' também não foi pequeno, porque tinha muito lá também e usado como umas vigotas grandes. Algumas foram utilizadas e outras compradas.

L: Durante o desenvolvimento do projeto foi preciso detalhar mais, os encaixes.. 
JM: a gente detalha bastante

L: Por as peças não virem num padrão, não serem pré-fabricadas... Talvez para cada peça precisa de uma...

JM: Não, não... Os detalhes são detalhes normais. Agente detalha muito o projeto. Acho que tinha alguma coisa por aqui...não... Depois eu posso até te arrumar, tinha uma série de desenhos...

L: Interessante...

JM: Depois eu arrumo para você.. Deu 20 e tantas folhas de projeto.. muito desenho, nós precisamos fazer uma maquete gráfica de todo

L: tipo maquete eletrônica?

JM: Sim

L: Quanto tempo levou o projeto?

JM: 1 ano..

L: O senhor lembra que ano que foi?

JM: 2005..

L: E a obra foi construída em 1 ano?

JM: É uma ano e pouco...

L: Foi construída logo em seguida do projeto?

JM: Para você ter idéia tava finalizando o projeto e eles começaram a construir

L: Qual é a sua opinião, o senhor acha que valei a pena ter reaproveitado a madeira, o pessoal gostou?

JM: já existia a madeira, na época a madeira acabou saindo mais caro... porque tinha muito gente querendo comprar essas tulhas... hoje você trabalhar com madeira... hoje eu prefiro... nos estamos com um projeto de um hotel que acabou não saindo, nós 
fizemos um anteprojeto e a gente pensou tudo em madeira laminada, porque a madeira laminada ao invés de madeira de lei. Primeiro lugar, ta muito cara, ta acabando... eu acho que tem que acabar de usar.. num tem mais jeito... entao a gente pensou em madeira laminada...

L: Pela praticidade, pelo custo...

JM: O custo é maior inclusive..

L: é mais que a madeira de lei?

JM: é praticamente a mesma coisa, mas não acha mais (lei), não adianta. Madeira hoje a gente vai deixando de usar...

L: De repente, só se for um uso mais consciente, de áreas de reflorestamento, ter um uso mais racional...

JM: Olha, a minha casa eu fiz tudo de caixilho de madeira que tinha numa casa no local... era tudo... a madeira tava lá... 30, 40 anos já... e... eu peguei a madeira e pensei num caixilho simples... num negócio que dava para usar com aquela madeira...

L: Certo...

L: Em relação à mão de obra? Porque eu percebo que essas coisas... fica cada vez mais difícil você arranjar um especialista... cuidadoso...

JM: Não, ainda tem gente que sabe trabalhar com madeira

L: Vocês não tiveram muita dificuldade na execução?

JM: Não.. Tem gente que sabe... Sabe tem alguns lugares que eles preparam... a USP ia montar curso de madeira aqui...

L: é que eu sinto um pouco que essas coisas eram passadas de pai pra filho, uma coisa familiar

JM: é, mas você pega por exemplo, eu sei que na Espanha tem, na Alemanha tem, tem cursos em universidade... Porque lá eles trabalham com muita madeira

L: Tipo Wood Frame, né? 
JM: É, nos EUA eles trabalham muito com Madeira

L:É, a maioria das casas lá são de madeira. Mas é mais racionalizado né...

JM: Eles trabalham muito lá com uma espécie de Pinus, ele trabalham muito lá com a Teca né... que tá entrando no Brasil agora

L: Pinus eu vejo mais, teca...

JM: é uma madeira muito boa, eu não conheço... mas já está entrando no Brasil e estão utilizando

JM: a madeira vai ficar proibitivo..

L: Mesmo móveis... antes eram tudo móveis de madeira... e hj... é mais industrializado...

JM: é muito caro né...eu acho que quem fez já fez. Num consegue mais... você não acha mais madeira... muito difícil, também tá acabando..

L: Mesmo o cliente, é difícil chegar um cliente que aceite usar estrutura de madeira.... tem a idéia de que madeira é mais manutenção...

JM: é

L: a maioria quer mesmo concreto, alvenaria

JM: eu prefiro usar alumínio

L: ainda também tá caro... mas se começar mais...

JM: Não, alumínio tá mais ...

L: acessível?

JM: ta mais acessível. E agora tá saindo uns caixilhos de PVC...

L: A maioria dos projetos que o senhor realiza é em concreto, alvenaria..

JM: sim, a maioria é em concreto, alvenaria. Madeira, esse foi o primeiro projeto que eu trabalhei com estrutura totalmente de concreto... 
L: o alumínio seria mais para obra comercial?

JM: Não, você usa o alumínio para... com pintura branca e acabou...

L: em residência também:

JM: é

L: Não é caro?

JM: Não é barato, mas é uma coisa que você coloca lá e esquece...

L: Agora seria alguma consideração final que o senhor tem em relação ao projeto, qual foi a maior dificuldade, ou o maior benefício...

JM: Eu acho que todo projeto, eu encaro o projeto como uma espécie de desafio. Eu nunca tinha feito uma estrutura de madeira ... então eu acho que tem que ir atrás, estudar... nunca fiz um hospital pequeno e agora estou fazendo ... vou estudar e ... to fazendo uma fábrica aqui... eu nunca tinha feito uma fábrica e tive que estudar... analisar tudo... máquina por máquina.. como é a produção.. tem que estudar as leis... tudo isso... tamanho de máquinas... cargas...

L: um aprendizado constante...

JM: eu acho que todo projeto é um desafio. Alguém chega: 'vc so faz isso?' não eu faço de tudo desde que tenha condição de estudar e quando eu não entendo do assunto eu procuro alguém que entenda e trabalho junto com essa pessoal. Tem o engenheiro que trabalha com a gente a questão de conforto térmico, eu tava conversando com um arquiteto que só trabalha com questão de acústica, vai trabalhar junto com esses caras, porque eu não entendo dessas coisas. O que você entende, é pro gasto, é para conversar ... e aqui assim, a gente procura não... não tem essa questão assim: 'isso é coisa de engenheiro'... aqui o projeto sai com uma estrutura ... pode ser até que a gente discuta... olha, vamos mudar isso aqui, ficaria melhor se fizesse assim e tal, a gente senta e discute, mas o projeto sai com estrutura daqui. 0 nosso projeto já tem uma estrutura

L: Mas o engenheiro faz o cálculo? 
JM: ele faz o cálculo e eventualmente a gente discute. Esta estrutura que saiu aqui (maquete) houve alteração aqui em cima, porque essa viga não chegava aqui, ela vinha e saia o contrário, de cada pilar. Ele propôs 'vamos aumentar a altura dessa viga e duplicar essa vigota aqui e ela afasta em cima', então a gente eliminou aquilo que estava, so saiu estas 4, saiam 2, 2 e 2.

L: É,não tem como uma pessoa saber tudo... envolve o calculista, o especialista em acústica e vai agregando no projeto..

JM: Esse negócio de a gente dominar tudo, esse negócio não existe. Então eu acho que você tem que saber alguma coisa para poder sentar e conversar, eu acho que isso é fundamental. Eu aprendi um pouco de estrutura na escola, eu tive um cara muito bom, que é o Marco Franco e eu me interesso também por uma questão, que eu acho que é a arquitetura quem define a estrutura, eu acho que é o arquiteto, não tem essa

\section{L: Não tem como separa né}

JM: a gente não consegue separar, é através da modulação, é através de uma idéia que você lança no papel e aparece. Embora que eu acho assim, eu gosto muito do Gaudí. O Gaudí não tinha aquela, o pilar tem que ser assim, $333 \ldots$ não... muitas vezes você rompe com a coisa e faz de outra forma, isso você pode fazer

L: ele é mais orgânico, a arquitetura dele... ah, aquele artigo que te falei já foi pré aprovado num congresso, só preciso fazer algumas alterações e mandar, ai você quer, daí eu colocaria na nota de rodapé, entrevista realizada com o arquiteto autor do projeto, ou prefere que ponha seu nome..

JM: Como você quiser

L: Porque eu pergunto, porque tem gente que as vezes gosta, tem gente que faz questão...

L: Bom, então, eu acho que as questões da entrevista eu já perguntei, tem tudo o que eu queria, o que eu precisava as vezes, seria assim, porque as fotos do edificil eu já tirei e ficou bem legal, mas o Marcio comento que se tivesse, eu até perguntei lá, mas eles não me passaram nada, se você tem algumas fotos da obra. 
JM: olha, tem algumas aqui, aqui a foto...

\section{Entrevista com a Arquiteta 02}

Entrevista realizada em Outubro de 2011, na prefeitura do Campus da USP de São Carlos, SP, sobre a reutilização da cobertura metálica de um hangar, no ginásio da universidade.

Observações:

A Estrutura foi proveniente do Crea - Broa. As peças foram numeradas, desmontada e montadas. As esperas foram montadas mais largas para deixar uma folga. Deu para aproveitar tudo e não houve perdas, isso fez com o projeto se tornasse economicamente viável

O antigo hangar serviria de apoio de uma pista para um curso de aviação que nunca chegou a ser implantado. A montagem durou aproximadamente 2 semanas. Foi construído na década de 90.

\section{Entrevista Engenheiro da empresa A}

Entrevista realizada em Junho de 2012, com o engenheiro da empresa A, sobre o processo de demolição controlada.

Observações da entrevista:

A empresa é de 1989, é pioneira na tecnologia de corte adiamantado. A empresa tem 35 funcionários de campo e total de 50. Também realizam o Hot Tapping, em tubulações e galerias É cadastrada no CREA e emite ART, o cliente vai atrás do alvará de demolição.

A demolição controlada foi utilizada na eclusa de Tucurui, porque não poderia ter vibração, seria arriscado fazer a demolição convencional, também para evitar danificar a estrutura.

Foram retirados blocos de concreto, cortados com fio adiamantados. Os blocos de concreto não foram reutilizados, mas poderiam ser colocados nas encostas. O peso era de cada bloco variou entre 9 a 30 toneladas. 
A equipe faz um plano de corte antes de iniciar o trabalho. Foram necessárias 6 pessoas. Foi utilizada a máquina de corte adiamantada e depois as peças foram içadas. Precisa ter uma programação antes de executar a demolição para racionalizar os custos.

A empresa também fazer cortes em estrutura metálicas, mas a empresa é especializada em corte de estrutura de concreto.

Quando possível, levam britador para a obra, lá mesmo brita o concreto e separa do aço (se for armado). A vantagem é que faz isso no local, então não tem o impacto do transporte, de lá já vai direto para onde vai ser utilizados. Geralmente o aço vai para reciclagem e o concreto é vendido como substrato para pavimento e também pode ser misturado com o concreto.

O que mais incentiva a reutilização dos materiais são as vantagens econômicas. Algumas empresas reutilizam materiais para pontuarem no LEED.

As possibilidades de desmontagem variam em relação ao prazo. Os principais tipos de edificações são siderúrgicas, obras portuárias, papeleiras e petroquímicas

Os equipamentos são: máquina de corte de fio adiamantado, flat saws, maquitão (hand saws), wall saws, iron saws e perfuratrizes. Algumas máquinas são compradas e outras feitar por eles.

A empresa não possui depósito de materiais.

A parte mais frágil da máquina de fio adiamantado é a ligação entre os fios, que pode acontecer de ceder.

Os equipamentos de segurança são os convencionais da construção civil (capacete, protetor auricular, luva, óculos,...)

A mão de obra é fixa e especializada, tem em média de 6 a 8 anos de casa.

A contratação é feita pelas construtoras. O orçamento é dado pelo projeto e visita às obras. A empresa tem o ISO 9.000 e 14.000 


\section{E. Questionário respondido pelo diretor da empresa B}

Questionário respondido pela Empresa B, realizada via e-mail.

Dados gerais

1. Nome / local

DESMONTEC - SÃO PAULO (SP)

2. Há quanto tempo está no mercado

40 ANOS.

3. Origem da empresa

4. Número de funcionários

5. Quais são os serviços prestados

DEMOLIÇÃO, DESMONTE DE ROCHA, IMPLOSÃO E RECICLAGEM DE RESÍDUOS

6. Possui equipamentos próprios (ferramentas, máquinas, caminhões)

SIM

7. Área da empresa

8. Algum serviço é terceirizado

Demolição / Desmonte

9. Como é feita a contratação do serviço

PESSOALMENTE, TELEFONE E E-MAIL.

10. Qual é o perfil do cliente

CONSTRUÇÃO CIVIL, CONSTRUÇÃO PESADA, INDÚSTRIAS, MINERAÇÃO E SIDERURGIA.

11. Qual é o perfil dos edifícios

EDIFICAÇÕES DE MÉDIO E GRANDE PORTE

12. Como é feito o orçamento

AREA QUADRADA CONSTRUIDA

13. Como é planejado

DE ACORDO COM O CRONOGRAMA SOLICITADO

14. Quais são as etapas

- ISOLAMENTO E SINALIZACAO DA AREA

- INSTALACAO DE CANTEIRO

- ESCORAMENTOS, ANDAIMES, BANDEJAMENTOS E PROTEÇÕES

- DEMOLIÇÃo

- CARGA E TRANSPORTE PARA BOTA-FORA

15. São consultadas plantas ou outros documentos

SIM. QUANDO TEM. 
16. Como eles ajudam

LEVANTAMENTOS DE ÁREA E VOLUME E NOÇÃO DE ACESSOS.

17. Quais técnicas são mais utilizadas

A FRIO COM USO DE MÁQUINAS E A FOGO COM EXPLOSIVOS.

18. Como é o processo, quando é necessário demolir apenas uma parte do edifício CORTE COM FIO DIAMANTADO DA ESTRUTURA PARA SEPARAR A QUE FICA DA QUE SAI.

Sobre os materiais / sistemas e resíduos

19. Quais materiais permitem maior reutilização e por quê

SUCATA FERROSA E INERTES BRITADOS (CONCRETO E ALVENARIA)

20. Como o projeto de arquitetura poderia contribuir

LEVANTAMENTO DE ÁREA E VOLUME A DEMOLIR

21. O que gera mais desperdício na demolição

O PRÓPRIO ENTULHO

22. Quais materiais / sistemas são necessário mais cuidado

ELÉTRICA

23. Quais materiais / sistemas demandam mais tempo

GESSO E LA DE VIDRO

24. Há preocupação com a disposição dos resíduos

SIM.

25. Seguem alguma norma, legislação ou resolução do CONAMA

SIM. CONAMA 307.

26. Há separação dos resíduos

SIM. É FEITO BAIAS DE TRIAGEM PARA CADA TIPO.

27. Os materiais reutilizados são separados na obra ou na empresa

DEPENDE DA OBRA E DA NEGOCIAÇÃO COM O CLIENTE.

28. Os materiais reutilizados são vendidos para outras empresas ou direto para os clientes

DEPENDE DA OBRA E DA NEGOCIAÇÃO COM O CLIENTE.

29. Há encomendas antes de iniciar a demolição / desmontagem (Se há, por quem)

30. Como é a feita reserva do material/ Informal ou por contrato

Sobre Desmontagem

31. O que motiva fazer a desmontagem:

- reaproveitamento dos materiais

- conceitos sustentáveis

32. Qual o perfil das obras que é mais recomendado 
OBRAS INDUSTRIAIS.

33. $O$ que poderia ser feito para facilitar (projeto, questões culturais, financeiras) PROJETO E INVENTARIO DOS MATERIAIS.

\section{F. Entrevista professora sobre Eko house}

Realizada em junho de 2012, na USP - SP.

Observações da entrevista:

A montagem e desmontagem da casa são feitas com ferramentas convencionais utilizadas atualmente na construção civil, mas alguns elementos precisaram ser içados. A casa utiliza 3 módulos diferentes.

Um dos principais conceitos se baseia na "energia zero", onde toda a energia consumida fosse produzida na casa. A estrutura é de elementos pré-fabricados, para facilitar a montagem e a desmontagem.

O sistema estrutura é de aço galvanizado e madeira cumaru e painéis OSB, em alguns elementos utilizados são de alumínio. A rampa de entrada é de estrutura de alumínio e madeira TECA (12 anos), como tratamento térmico (que dispensa tratamento químico). A madeira é fixada por encaixe e cavilha ou adesivo. Os caixilhos são de PVA (WEIKU), como vidros insulados duplos. São fixadas nos painéis e são isolantes termo-acústicos.

A residência foi projetada para diversas regiões climáticas. Além disso, há espaço entre os painéis de vedação, assim como nas lajes de piso e cobertura para colocar mais isolantes térmicos.

A casa também teve intenção poder ser montada em locais de difícil acesso. Há tratamento de água e resíduos.

Vai participar do "solar decathlon", na Espanha.

Quando desmonta, vai ser por painéis, assim há encaixes previstos para os elementos, além de encaixes para a elétrica e hidráulica. Foi necessário um ano de detalhamento da estrutura, para otimizar os encaixes que permitissem a montagem e desmontagem sem danificar as peças ou comprometer suas funções. 
No banheiro é utilizado o vaso seco (biolet, da Irlanda). A pia e chuveiro são normais. Os painéis externos são revestidos por placas de fibro-cimento com perfis de alumínios e juntas (JEENE). Os pisos internos serão de madeiras, encaixados e fixados em barrotes, nas áreas íntimas e social.

Nos banheiros será piso vinílico e placas de vidros como revestimento. Há peças embutidas nos painéis para fixação das bancadas. A parte externa e interna dos painéis são desmontáveis, o que facilita a manutenção da hidráulica, elétrica.

Os painéis e pisos são parafusados. Toda a montagem é encaixada ou parafusada. Alguns elementos são soldados, mas não serão desmontados.

As telhas são de alumínio. Há uma máquina que prensa as telhas e elas são entancadas, depois passa a máquina e é possível separá-las novamente. As placas solares são fixadas através de elementos prensados nas telhas, assim não é necessário furá-las, mesmo se precisar fixar algum outro elemento.

Há um espaço para reservatório de água, água quente, bombas, unidade condensadora, equipamento para conversão da eletricidade, controle do sistema elétrico. Haverá um sistema que umidificará a parte interna. As floreiras laterais são tanques para tratamento das águas cinzas

Foram montadas as 3 lajes em 2 horas. A montagem do núcleo central está prevista para 2 dias e mais um tempo para os arremantes, para a desmontagem também. Foi considerado também a maneira de transporte e o tamanho dos contêineres. A montagem da residência se iniciou em março, é um protótipo.

Fazem parte da equipe: 3 alunos da elétrica da pós-graduação, 2 alunos da automação, 3 alunos do sistema voltaico, 5 alunos geral, 8 alunos da graduação, 3 de apoio e logística.

Houve pouco resíduos, a maioria de madeira Cumaru, que será reutilizada para painéis decorativos ou algo do tipo.

As informações técnicas foram baseadas nas utilizadas pelas indústrias.

O projeto está em andamento desde 2008. A professora Cláudia aderiu ao projeto em 2009. Há união entre FAU, POLI, elétrica. 
Neste protótipo há 6 painéis para laje de forro, mais 6 painéis para o piso e 21 painéis verticais (incluindo os de caixilhos). Foram utilizados 8 mil parafusos, onde foram estudados e calculados todos os furos e encaixes. Foram compradas $5 \mathrm{~m}^{3}$ de madeira .

\section{G. Dados do acompanhamento da demolição}

Sobre a obra

Edifício Comercial (Salão de Beleza)

1. Dados da obra:

-Área: aproximadamente $200 m^{2}$

-Local: Av. Presidente Vargas, Ribeirão Preto - SP

$-\mathrm{N}^{\circ}$ de pavimentos: 1

2. Sistemas estruturais, subsistemas e materiais

- Estrutura: convencional, de concreto armado e vedação com tijolos cerâmicos

-Caixilhos: vidro temperado e vidro comum

- Alvenaria: tijolos cerâmicos

-Revestimentos: cerâmico

-Pisos: cerâmico

- Instalações elétricas: convencional

- Instalações hidráulicas: PVC

- Cobertura: telha cerâmica e estrutura de madeira

Sobre o processo de demolição / desmontagem

3. Equipamentos utilizados na demolição / desmonte: marretas / pé de cabra/ retro escavadeira ou concha na demolição

4. Número de funcionários: 3 para retirar os materiais que serão reutilizados, na demolição foi necessário 1 no caminhão (terceirizado), 1 na retro escavadeira (terceirizada) e 2 auxiliares da demolidora.

5. Quanto tempo levou (horas, dias, semanas): 1 semana para tirar o que pode ser reutilizado, 1 semana parada e 4 horas para demolir e limpar o terreno. 
6. Qual foi a técnica utilizada:manual para o que pode ser reutilizado e máquina para demolição da estrutura e alvenaria

7. Quais foram as etapas: revestimento metálico da fachada (1dia), cobertura (2 dias), retiradas de vidros, tubo de PVC, caixa d'água, demolição da estrutura e paredes em uma manhã.

8. Há alguma relação entre as etapas de demolição / desmontagem com as etapas da construção: sim, parece que são realizadas as etapas inversas. Começa retirando as telhas, a estrutura de madeira e tudo o que pode ser reaproveitado, como louças e vidros temperado. Depois é demolida toda a estrutura e realizada a limpeza do terreno.

Sobre as conexões

9. Como são as conexões:

- ligação química e pregos nas madeiras da cobertura

- instalações elétricas e hidráulicas embutidas na alvenaria e caixilhos de vidro e perfil metálico

10. Como estas conexões facilitaram / dificultaram o processo: danificam materiais e os tornam inutilizados

11. Grau de dificuldade para desmontar / desencaixar / demolir

12. Sugestões ou observações para melhor aproveitamento dos materiais e economia de tempo e esforço

Sobre os resultados obtidos

13. Quais materiais puderam ser mais bem aproveitados: madeira e telhas metálicas ou cimentícias, louças (pias e vasos sanitários), tubos de PVC, caixa d'água, vidros temperados (os que não eram temperados, não deu para reaproveitar)

14. Quais que obtém mais vantagens ao serem reaproveitados (em relação ao lucro e tempo). Por quê?

15. O que impediu que outros materiais fossem mais bem aproveitados: ligações entre eles e baixo custo de revenda

16. Quais foram os materiais / sistemas que demandaram mais cuidados

17. Qual o destino destes materiais retirados: depósito da empresa para revenda 
18. Qual o destino dos resíduos: Serão utilizados para aterrar a margem de um corgo (estrutura de concreto armado, alvenaria de tijolos cerâmicos, forro e detalhes de gesso, pisos, revestimentos).

19. Houve separação de materiais (dos resíduos e dos que serão reutilizados): alguns materiais são separados e empilhados na própria obra, depois levados para o depósito deles e separados por uso

20. Houve preocupação em seguir normas ou legislações: a empresa é cadastrada no Crea e emite ARTs. 


\section{H. Proposta de Checklist}

A seguir foram propostos dois checklists, baseados nas questões discutidas ao longo do trabalho. O objetivo é auxiliar na incorporação do Projeto para o Desmonte ao longo do desenvolvimento do projeto de maneira prática. Além dos arquitetos, esta ferramenta também pode ser utilizada pelos engenheiros, construtores, proprietários e usuários. Ela auxilia na aplicação prática do Projeto para o Desmonte.

Além disso, pode ser revista para facilitar a manutenção e até mesmo auxiliar no processo de desmontagem. $\mathrm{O}$ ideal é que esta ferramenta acompanhe todo o desenvolvimento do projeto, desde a concepção inicial, até nos detalhamentos finais, como revestimentos.

O primeiro é composto por questões gerais da construção civil e projeto para o desmonte, que tem apenas como opção sim, não e demais observações relevantes. A intenção foi desenvolver uma ferramenta prática e objetiva para avaliação do projeto e analisar se atende às questões relacionadas ao projeto e desmonte na construção civil.

A tabela foi dividida em grupos (ligações, revestimentos e acabamentos, sistema construtivo, materiais, geral) para facilitar a análise.

\section{Checklist referente a questões gerais}

Tabela 17 Checklist do Projeto para o Desmonte na construção Civil

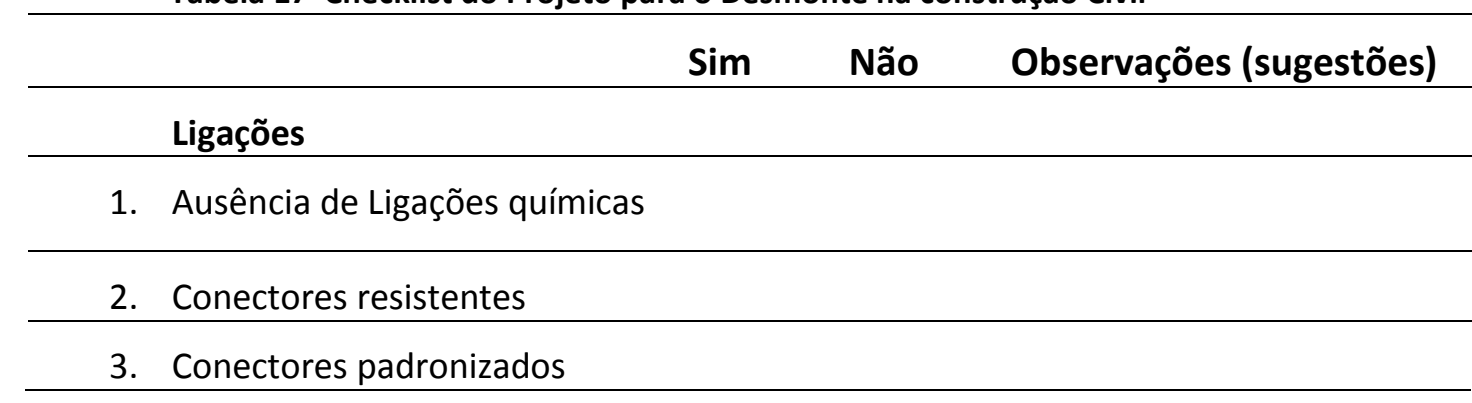


4. Número reduzido de diferentes conectores

5. Possibilidade de reuso dos conectores

6. Indicação de composição dos conectores

7. Conectores numerados Revestimentos e Acabamentos

8. Ausência de Revestimentos e acabamento químicos

9. Revestimentos encaixados ou conectados

10. Evitou escolha dos revestimentos apenas por conceitos estéticos

\section{Sistema Construtivo}

11. Sistema Construtivo Modular

12. Sistema Construtivo com possibilidade de desmonte

13. Evita peças de grandes dimensões

14. Elementos pré-fabricados

15. Estrutura resistente

16. Resiste a montagem e desmontagem

17. Encaixado ou ligado por conectores

\section{Materiais}

18. Materiais padronizados

19. ACV dos materiais e sistemas utilizados

20. Ausência de materiais tóxicos ou danosos

21. Utilização de materiais reciclados

22. Análise dos materiais reciclados (ACV, toxinas, consumo de energia,etc)

23. Evita materiais compostos 
24. Materiais leves

25. Materiais duráveis e resistentes

26. Há materiais reutilizados

27. Priorizou materiais que possam ser reutilizados

28. Os materiais utilizados poderão ser desmontados

29. Os materiais utilizados poderão ser reciclados

30. Os materiais, peças e componentes estão identificados

Geral

31. Projeto e documentos com dados atualizados

32. É possível acessar todas as partes das edificações

33. Os pontos de desmonte estão identificados

34. As dimensões das peças são reduzidas

35. É possível desmontar com ferramentas manuais

36. Foi considerado o transporte dos elementos e materiais

37. É possível desmontar partes separadas do edifício, sem danificar outras

38. Foram consideradas as diferentes camadas do edifício

39. A desmontagem de sistemas e subsistemas são independentes

40. O cliente está ciente do conceito utilizado

41. Considerou tecnologias, para desmontagem, disponíveis atualmente no mercado

42. Foi considerado o ACV do edifício, sistemas, subsistemas 
e materiais

43. Identificação da composição

de materiais, peças e

componentes

44. Análise de quais partes do

edifício estão mais sujeitas a

mudanças funcionais

45. Foi considerado o tempo ideal

de desmonte

46. Foi prevista a sequencia do desmonte

47. Foi considerado o porquê, o quê, onde e quando deve ser desmontado

48. Edifício Flexível

49. Soluções adequadas à tecnologia atual

50. Foi considerado o custo e tempo da desmontagem

51. Os elementos mais caros do edifício foram identificados

52. O layout é simples, padronizado e regular

53. Elementos a ser desmontados são compatíveis com a escala humana

54. Serão gerados resíduos no desmonte

55. Há solução prevista para os resíduos

Através deste checklist é possível observar de forma mais clara os conceitos incorporados no Projeto para o Desmonte, além de auxiliar na aplicação prática. Esta ferramenta pode contribuir com o desenvolvimento do projeto e tornar o processo mais rápido e eficiente. 


\section{Checklist com pontuação}

Neste checklist o objetivo foi graduar as questões abordadas no desenvolvimento do projeto. Assim é possível estabelecer metas de pontuação pelas empresas e escritórios de arquitetura, ou até mesmo para uma certificação sustentável.

Os pontos são entre 1 e 3 . Onde 1 é ruim ou muito difícil, 2 é razoável e 3 seria o ideal. A definição entre o que é considerado ruim e ideal pode ser estipulada pelos próprios usuários do checklist, pois a intenção é ser usado pelos próprios projetistas para que seus projetos contribuam, de maneira eficaz, com a desmontagem.

Tabela 18 checklist com pontuação

1. Desfazer ligações entre elementos estruturais

2. Desfazer ligações entre sistemas (hidráulicos, elétrico, etc)

3. Desfazer ligação entre sistemas de vedação

4. Desfazer ligação de acabamentos e revestimentos

5. Desfazer ligação de caixilhos

6. Possibilidade de reutilização dos elementos utilizados para ligações

7. Grau de toxina das ligações

8. Resistência das ligações

9. Resistência do sistema estrutural

10. Resistência dos materiais

11. Possibilidade de reutilização do sistema estrutural

12. Possibilidade de reutilização dos materiais

13. Possibilidade de reciclagem do sistema estrutural

14. Possibilidade de reciclagem dos materiais 
15. Padronização do sistema estrutural

16. Padronização dos demais sistemas

17. Padronização dos acabamentos e revestimentos

18. Sistema estrutural compatível com a escala humana

19. Demais elementos de desmonte compatível com a escala humana

20. Manuseio dos elementos desmontados

21. Transporte dos elementos desmontados

22. Utilização das ferramentas para desmontagem do sistema estrutural

23. Utilização de ferramentas para desmontagem de demais elementos

24. Acesso a diversas partes da edificação

25. Manutenção dos sistemas da edificação

26. Desconectar peças do sistema estrutural

27. Desconectar peças do sistema hidráulico

28. Desconectar peças do sistema elétrico

29. Desconectar peças dos demais sistemas

30. Desmontar diferentes camadas sem prejudicar outras

31. Desmontar parte da edificação

32. Identificar materiais utilizados

33. Separar materiais compostos utilizados no edifício

34. Acesso aos documentos do edifício (plantas, memoriais, etc)

35. Identificar pontos de desmontagem 
36. Identificar o momento ideal da desmontagem

37. Transporte das peças desmontadas

38. Armazenamento das peças desmontadas

39. Separação dos sistemas

40. Disponibilidade do uso de tecnologias atuais para o desmonte

41. Identificar a ACV do edifício

42. Identificar a ACV do sistema estrutural

43. Identificar a ACV dos demais sistemas

44. Identificar a ACV dos materiais

45. Identificar a sequencia do desmonte

46. Adaptar novas tecnologias ao edifício

47. Adaptar novos usos ao edifício

48. Identificar os elementos mais caros da construção

49. Encontrar soluções para os resíduos gerados na desmontagem

Total Parcial

Total

Esta tabela auxilia na aplicação dos conceitos do Projeto para o Desmonte ao longo do desenvolvimento do projeto. Além disso, pode auxiliar na avaliação do projeto e como foram consideradas as diversas questões abordadas. Quanto mais pontos marcados, mais fácil, prática, rápida e econômica será a desmontagem. 
Por exemplo, no primeiro ítem "Desfazer ligações entre elementos estruturais", se for marcado o número 01, se considera uma ligação difícil de desfazer, como o cimento; se marcar a opção dois, seria ligações por pregos e parafusos, que podem ser desfeitas, mas em alguns casos danificam os materiais; na opção 03 são as peças encaixadas que seriam fáceis de ser desmontadas sem danificar os materiais.

O checklist foi desenvolvido baseado nas considerações analisadas ao longo da revisão bibliográfica e estudos empíricos. Há vários pontos que diversos autores concordam que devem ser analisados e na prática também foram observados a necessidades de considerá-los, assim estes itens foram inseridos na tabela. Dessa maneira, visa se tornar uma ferramenta prática para obter resultados objetivos.

Esta tabela pode ser utilizada pelos arquitetos e engenheiros ao longo do desenvolvimento do projeto e também por construtores, investidores e usuários, para obter melhores resultados quando almejarem aplicar o conceito do Projeto para o Desmonte. Além disso, será um importante documento a ser analisado quando for feita a desmontagem do edifício. 